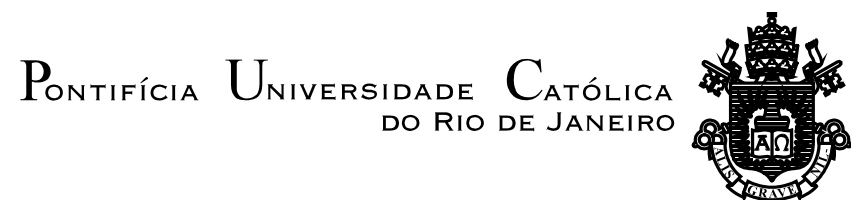

Ebe Campinha dos Santos

\title{
Trafico e Gênero: a moralização do deslocamento feminino
}

Tese de Doutorado

Tese apresentada ao Programa de Pós-graduação em Serviço Social da PUC-Rio como requisito parcial para obtenção do título de Doutor em Serviço Social.

Orientador: Profa. Sonia Maria Giacomini

Rio de Janeiro

Setembro de 2012 


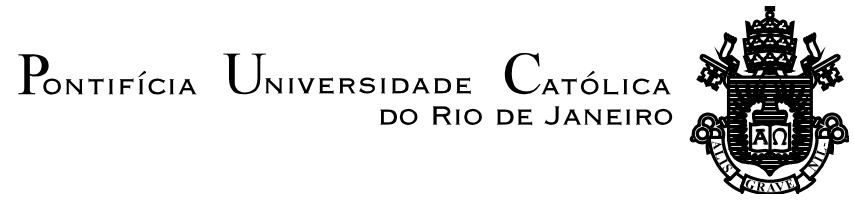

Ebe Campinha dos Santos

\title{
Tráfico e Gênero: a moralização do deslocamento feminino
}

Tese apresentada como requisito parcial para obtenção do grau de Doutor pelo Programa de PósGraduação em Serviço Social do Departamento de Serviço Social do Centro de Ciências Sociais da PUC-Rio. Aprovada pela Comissão Examinadora abaixo assinada.

\author{
Profa. Sonia Maria Giacomini \\ Orientador \\ Departamento de Sociologia e Política - PUC-Rio
}

Profa. Inez Terezinha Stampa Departamento de Serviço Social - PUC-Rio

Profa. Ilda Lopes Rodrigues da Silva Departamento de Serviço Social - PUC-Rio

Prof. Helion Póvoa Neto

UFRJ

Profa. Adriana Gracia Piscitelli UNICAMP

Profa. Mônica Herz

Vice-Decana de Pós-Graduação do Centro de Ciências Sociais - PỦC-Rio

Rio de Janeiro, 10 de setembro de 2012 
Todos os direitos reservados. É proibida a reprodução total ou parcial do trabalho sem autorização do autor, do orientador e da universidade.

\section{Ebe Campinha dos Santos}

Graduou-se em Serviço Social pela Universidade Federal do Rio de Janeiro em 1988. Concluiu o Mestrado em Serviço Social pela Pontifícia Universidade Católica em 1997. É Assistente Social e Professora Mestre Adjunto I da Universidade UNIGRANRIO desde 1999, onde leciona nos cursos de graduação e de especialização. Foi professora auxiliar do Curso de Serviço Social da Pontifícia Universidade Católica no período de 2007 a 2011. Tem experiência como assistente social na área sócio jurídica atuando com direitos humanos, relacionados especialmente à infância e juventude, à mulher em situação de violência, tráfico de pessoas e LGBT. Participa dos Conselhos de Direitos e Fóruns da Sociedade Civil do Município de Duque de Caxias - RJ, referentes aos direitos da mulher e de crianças e adolescentes (desde 2000). Foi presidenta do Conselho da Mulher de Duque de Caxias (2009-2010). Área de pesquisa: violência contra a mulher, crianças e adolescentes.

Ficha Catalográfica

Santos, Ebe Campinha dos

Tráfico e gênero: a moralização do deslocamento feminino / Ebe Campinha dos Santos ; orientadora: Sonia Maria Giacomini. - 2012.

270 f. : il. (color.) ; $30 \mathrm{~cm}$

Dissertação (mestrado)-Pontifícia Universidade Católica do Rio de Janeiro, Departamento de Serviço Social, 2012. Inclui bibliografia.

1. Serviço social - Teses. 2. Gênero. 3. Tráfico de mulheres. 4. Migração feminina. 5. História de vida. I. Giacomini, Sonia Maria. II. Pontifícia Universidade Católica do Rio de Janeiro. Departamento de Serviço Social. III. Título. 
Aos meus dois amores, minha filha Marina e meu marido Rogério. 


\section{Agradecimentos}

Estes quatro anos de Curso de Doutorado em Serviço Social representaram para mim: desafio, construção, amadurecimento e superação. Por isso venho agradecer a todos que contribuíram para que eu pudesse hoje concluir essa etapa.

À Deus, em cuja fé depositada, me fez superar todos os obstáculos, como o cansaço, as incertezas e a ausência junto a minha família.

À minha mãe e a minha sogra pelas orações diárias e por serem verdadeiros anjos em minha vida.

Ao meu marido Rogério pela compreensão e o apoio incondicional e a minha filhinha Marina, para quem me dedico para construir um presente e um futuro melhor. $\mathrm{O}$ amor de vocês confortou meu coração em diversos momentos, me motivando a continuar.

À minha irmã Cláudia e aos meus irmãos Leonardo e João pelo apoio e incentivo. E à minha cunhada Sandra e Edmilson, pelo apoio e por cuidar em muitos momentos de minha filha para que eu pudesse me dedicar aos estudos. Aos meus cunhados e cunhadas, sobrinhos e sobrinhas e familiares em geral pela compreensão diante de tantos momentos de ausência.

Ao Programa de Pós- graduação em Serviço Social da PUC-Rio, pela bolsa de isenção, sem a qual, não poderia ter realizado o doutorado.

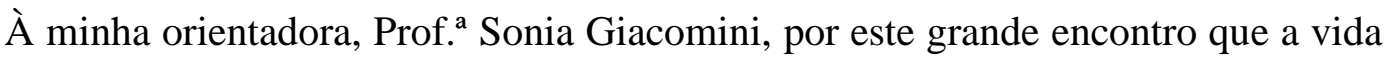
acadêmica me proporcionou. Meu profundo agradecimento e minha homenagem carinhosa, pela sua cumplicidade com este trabalho e pelos valiosos momentos de aprendizado que me proporcionou. 
À Prof. ${ }^{a}$ Luiza Helena, diretora do Curso de Serviço Social e à Prof. ${ }^{\mathrm{a}}$ Inez Stampa, Coordenadora da Pós-graduação e também membro da banca examinadora da tese, por sua valiosa contribuição e incentivo.

Às minhas professoras do Mestrado e Doutorado, pelo acolhimento, atenção e principalmente pelo ambiente acadêmico arejado e aberto ao pensamento crítico e ao debate de ideias.

Aos funcionários do Departamento de Serviço Social e em especial, à Joana, pela atenção, disponibilidade e empenho nos muitos momentos que precisei dos serviços da secretaria.

Meu profundo agradecimento a todas as mulheres que se dispuseram a participar deste estudo relatando suas histórias de vida, contribuindo desta forma para o enriquecimento da pesquisa de campo.

À Nina Quiroga, representante do Núcleo de Enfrentamento ao Trafico de Pessoas no Rio de Janeiro e, Marcele Marques, representante do Consórcio Trama, pelas entrevistas concedidas, trazendo de forma concreta os avanços e dilemas enfrentados em relação ao tráfico de pessoas.

Ao professor Hélion Povoa Neto, por ter abraçado este compromisso de estar presente nas duas bancas de qualificação e agora na defesa dessa tese. Minha admiração pelo seu profundo conhecimento e pela sua simplicidade e grande disponibilidade em partilhá-lo com os iniciantes. Isto o torna um grande mestre e incentivador para aqueles que querem continuar sempre aprendendo.

À professora Ilda Lopes, que tenho com muito carinho e profunda consideração; a quem credito parte de minha formação profissional como assistente social, pela presença marcante e sempre serena, incentivando a busca constante do conhecimento e do aprimoramento profissional. 
À professora Adriana Gracia Piscitelli, cujos estudos me inspiraram e me fizeram avançar neste debate sobre o tráfico de pessoas, agradeço pela oportunidade de têla na minha banca.

À professora Denise Pini, pelas suas valiosas contribuições nas duas etapas de qualificação do doutorado. À professora Andréa Lopes, amiga e incentivadora e ao Prof. Rafael Soares, por aceitarem o convite para participarem da banca na condição de suplentes.

Minha homenagem especial a Prof. ${ }^{a}$ Myrtes de Aguiar Macêdo (in memorian), minha orientadora no Mestrado, por sua dedicação e amor à sua profissão de docente, deixando para nós discentes, exemplo de compromisso, seriedade e a vontade de aprender sempre mais. E a querida professora Ana Quiroga, por me despertar para o tema da migração e pelos empolgantes debates em sala de aula.

Aos colegas de turma: Eliza, Márcio, Neli, Laura, Inês e Bruno pelos muitos momentos de angústia, de alegrias e de solidariedade diante do grande desafio colocado para nós.

Agradeço as amigas: Vera Lúcia Pereira, pela presença constante e pelo ombro amigo nos momentos difíceis; a Luciene Medeiros, pela solidariedade e apoio e a Vera Salgado, pelas transcrições das gravações.

Aos amigos da UNIGRANRIO: Cristiane Queiroz, Tatiane Nunes, Sandra Baliza, Carla Morani, Adriana Gomes, Débora Lopes, Diego Rivas, Renata Coelho, Robson Roberto, Maria Márcia e minha coordenadora Marina Amoedo, pelo apoio e incentivo.

Agradeço aos amigos do Consórcio Trama: Frans Nederstigt, Carlos Nicodemos, Alessandra Page, Lúcia Xavier e Nanko, Marcele Marques, Fabiana Pereira pelos debates e troca de ideias sobre o tráfico de pessoas. 


\section{Resumo}

Santos, Ebe Campinha dos; Giacomini, Sonia Maria. Tráfico e Gênero: a moralização do deslocamento feminino. Rio de Janeiro, 2012. 270p. Tese de Doutorado - Departamento de Serviço Social, Pontifícia Universidade Católica do Rio de Janeiro.

O tráfico de pessoas vem ocupando o debate nacional e internacional, expressando a preocupação de diversos países através da criação de legislações e políticas de enfrentamento e combate a este crime de violação de direitos humanos. As mulheres aparecem como as principais vítimas em estatísticas oficiais e em diversos estudos e pesquisas, que divulgam dados alarmantes, o que vem subsidiando a criação de aparatos de repressão a este crime transnacional, mas também de ações de proteção e de controle sobre as mulheres quando em deslocamento. Em nome da proteção e prevenção ao tráfico de mulheres, acaba-se reproduzindo relações de poder, que recolocam a mulher, no processo migratório, como vulnerável, submissa e indefesa, deixando invisível sua autonomia, anseios e desejos, como protagonista na construção de sua própria identidade e história. A mulher aparece ora como vítima, o que não necessariamente lhe garante efetiva proteção, ora como subversiva, quando identificada ou associada à prostituição voluntária ou a migração irregular. Este estudo vem trazer à reflexão o conhecimento já construído sobre o tráfico de mulheres, mas também lacunas, divergências e ambiguidades, mediante a análise dos diferentes paradigmas presentes no debate e nas ações contra o tráfico. A interseção entre as temáticas do tráfico de mulheres e a migração feminina internacional, permite situar o tráfico não como fenômeno isolado. Ao contrário, o tráfico ganha nova dimensão quando pensado dentro dos processos migratórios contemporâneos, no contexto da globalização e da reestruturação produtiva, que impulsionam milhares de pessoas e em específico, mulheres, a se deslocarem pelo mundo à procura de melhores oportunidades de vida e trabalho. Esta visão mais ampla permite a compreensão de aspectos econômicos, políticos, culturais e sociais que irão favorecer a existência e permanência do tráfico de mulheres. A pesquisa de campo realizada trouxe a trajetória de cinco brasileiras e suas experiências de emigração, desde a 
decisão de migrar até o retorno ao Brasil, identificando a diversidade de situações, expectativas, sonhos, amores e desamores, temores e sofrimento diante de situações de violência, inclusive do tráfico. O objetivo da pesquisa de campo foi investigar como estas mulheres percebem e resignificam sua história de deslocamentos, identificando a existência de fatores que as colocaram em situações de risco pessoal e social e de violação de direitos. Outro aspecto observado foi como estas mulheres percebem as ações dos diversos sujeitos (Estado, organizações da sociedade civil, família, amigos, grupos criminosos e outros) e as estratégias utilizadas por elas na superação das dificuldades e nas interrupções das violações. Por fim pretendeu-se com este estudo repensar certos conceitos e ações no enfrentamento ao tráfico de mulheres, evitando a construção de "verdades", e a reiteração de alguns estereótipos, entre eles o da mulher "vítima" em perigo ou fora de lugar, "perigosa", porque deslocada do universo da família, da casa, da pátria, das redes de apoio e proteção nas quais a mulher poderia idealmente experimentar sua condição de gênero. Ao contrário, a intenção foi de trazer algumas ambiguidades presentes no tratamento da complexidade deste tema, a fim de subsidiar novos debates.

\section{Palavras-chave}

Gênero; Tráfico de Mulheres; Migração feminina; História de Vida. 


\section{Abstract}

Santos, Ebe Campinha dos; Giacomini, Sonia Maria (Advisor). Trafficking and Gender: the moralization of female shift. Rio de Janeiro, 2012. 270p. Doctoral Thesis - Social work department, Pontifical Catholic University of Rio de Janeiro.

The trafficking in people has been occupying the national and international debate, expressing the concern of many countries through the creation of laws and policies of confrontation and combat this crime of violation of the human rights. Women appear as the main victims in official statistics and in various studies and researches, which disseminate alarming data, which has been subsidizing the creation of apparatuses of repression in this transnational crime, but also to actions for protection and prevention and control over women when in displacement. In the name of protection and prevention to trafficking of women, it is reproducing power relations, which put the woman in the migration process, as vulnerable, submissive and defenseless, leaving invisible her autonomy, desires and wishes, as the protagonist in the construction of her own identity and history. The woman appears sometimes as a victim, which does not necessarily ensures effective protection, now as subversive, when identified or associated with the voluntary prostitution or irregular migration. This study comes to bring the reflection the knowledge already built on the trafficking of women, but also the omissions, discrepancies and ambiguities, through the analysis of different paradigms present in debate and in actions against trafficking. The intersection, between the themes of trafficking of women and international female migration allows be trafficking not as an isolated phenomenon. On the contrary, the trafficking wins a new dimension when thought within the contemporary migratory processes, in the context of globalization and productive restructuring, which drives thousands of people and in particular, the women, to move the world in search of better opportunities in life and work. This boarder vision allows an understanding of economic, political, cultural and social which will promote the existence and permanence of the trafficking of women. The field research carried out, brought to the trajectory of five Brazilian women and their experiences of 
emigration since the decision to migrate to the return to Brazil, identifying the diversity of situations, expectations, dreams, loves and disappointments, fears and suffering before situations of violence, including the trafficking. The objective of the field research was to investigate how these women perceive and reframe their histories of dislocations, identifying the existence of factors that have placed them in a situation of personal and social risk and violation of rights. Another aspect is how these women perceive the actions of the various subjects (State, civil society organizations, family, friends, criminal groups, and others) and the strategies used by them, the overcoming difficulties and the interruptions of the violations. In the end, it was intended with this study, rethink some concepts and actions in dealing with the trafficking of women, thus avoiding the construction of "truths" and the reiteration of some stereotypes among them, the "victim" woman, in danger or out of place, "dangerous", because once moved from the realm of family, from home and homeland, the networks of support and protection, in which women could ideally try their condition of gender. On the contrary, the intention was to bring some ambiguities present in the treatment of the complexity of this topic, in order to subsidize new debates.

\section{Keywords}

Gender; Trafficking of women; women migration; history of life. 


\section{Sumário}

1. Introdução

2. O Trafico Internacional de Pessoas 28

2.1. Percurso histórico na construção do conceito de 29

Trafico de pessoas

2.2. O Protocolo de Palermo 36

2.3. O tráfico de pessoas na legislação brasileira 49

3. Gênero, Feminismos e Tráfico 60

3.1. O tráfico de escravas brancas 60

3.2. O tráfico de mulheres no debate dos movimentos 74

feministas contemporâneos

3.3. Gênero nas imagens das campanhas de combate 83

ao tráfico de pessoas

4. Tráfico no Contexto da Migração Feminina 92

4.1. A feminização das migrações 93

4.2. Tráfico e Contrabando 107

5. Condição de Gênero, Migração e Tráfico na Trajetória 118

de Mulheres Emigrantes da Região Metropolitana do

Estado do Rio de Janeiro

5.1. Contextualizando a pesquisa de campo 118

5.2. Trajetórias das mulheres entrevistadas 125

5.3. A motivação para migrar 132

5.4. A permanência no país de destino 143

$\begin{array}{ll}\text { 5.5.O retorno ao Brasil } & 157\end{array}$

6. Conclusão 166 
8. Apêndices 190

8.1. Apêndice 1 - Termo de Consentimento Livre e 190

Esclarecido (Mulheres)

8.2. Apêndice 2 - Termo de Consentimento Livre e 192

Esclarecido (Instituições)

Apêndice 3 - Carta de Apresentação às Instituições

9. Anexos 195

9.1. Anexo 1 - Decreto №. 5.591, de 13 de julho de 1905

9.2. Anexo 2 - Convenção Internacional para a Supressão 197 do Tráfico de Escravas Brancas, assinada em Paris em 04 de maio de 1910, e emendada pelo Protocolo assinado em Lake Success, Nova lorque, em 04 de maio de 1949

9.3. Anexo 3 - Convenção Internacional para a Repressão ao 202 Tráfico de Mulheres e de Crianças, de 30 de Setembro de 1921

9.4. Anexo 4 - Protocolo de Emenda da Convenção para a 205 Repressão do Tráfico de Mulheres e Crianças, concluída em Genebra, a 30 de setembro de 1921, e da Convenção para a Repressão do Tráfico de Mulheres maiores, concluída em Genebra, a 11 de outubro de 1933

9.5. Anexo 5 - Decreto $n^{\circ} 46.981$, de 8 de outubro de 1959 209

9.6. Anexo 6 - Decreto $n^{\circ} 5.017$, de 12 de março de 2004

9.7. Anexo 7 - Convenção do Conselho Europa relativa à

Luta contra o Tráfico de Seres Humanos

9.8. Anexo 8 - Lei n ${ }^{\circ} 11.106$, de 28 de março de 2005

9.9. Anexo 9 - Política Nacional de Enfrentamento ao Tráfico de Pessoas 


\section{Lista de Imagens}

Imagem 1 - Campanha vinculada na Alemanha em 2008

Imagem 2 - Campanha vinculada em Portugal em 2008

Imagem 3 - Campanha vinculada no Brasil em 2010.

Imagem 4 - Campanha vinculada na Suíça em 2008

Imagem 5 - Campanha vinculada em Luxemburgo em 2009

Imagem 6 - Campanha vinculada no Brasil em 2004

Imagem 7 - Campanha vinculada em Portugal em 2007 


\section{Lista de Quadros}

Quadro 1 - Alterações no Código Penal Brasileiro em relação

à tipificação do tráfico de pessoas

Quadro 2 - Movimento através das fronteiras

Quadro 3 - Síntese dos dados sociológicos das mulheres entrevistadas 


\section{Lista de Gráficos}

Gráfico 1 - Pessoas em situação de trabalho forçado no mundo por sexo (milhões)

Gráfico 2 - Porcentagem de trabalhadores forçados no mundo (milhões)

Gráfico 3 - Principais atividades exploradas no mundo na economia privada, por indivíduos ou empresas (milhões)

Gráfico 4 - Principais exploradores do trabalho forçado no mundo (milhões)

Gráfico 5 - Migrações internacionais (milhões) 98

Gráfico 6 - Migrantes internacionais com porcentagem da população mundial

Gráfico 7 - Porcentagem de mulheres sobre o total de migrantes internacionais

Gráfico 8 - Porcentagem de mulheres sobre o total de migrantes internacionais por região 


\section{Lista de Abreviaturas}

CATW- Coalisão contra o Tráfico de Mulheres

CECRIA - Centro de Referência, Estudos e Ações sobre Crianças e Adolescentes

CIAM - Centro Integrado de Atendimento à Mulher

CPB - Código Penal Brasileiro

CPMI - Comissão Parlamentar Mista de Inquérito

CREAS - Centro de Referência Especializado de Assistência Social

DEAM - Delegacia de Atendimento à Mulher

FMI - Fundo Monetário Internacional

FPNU - Fundo de População das Nações Unidas

GAATW - Aliança Global contra o Tráfico de Mulheres

MTE - Ministério de Trabalho e Emprego

NETP - Núcleo de Enfrentamento ao Tráfico de Pessoas

OEA- Organização dos estados Americanos

OIT - Organização Internacional do Trabalho

OIM - Organização Internacional para as Migrações

OMC - Organização Mundial do Comércio

ONG - Organização Não Governamental

ONU - Organização das Nações Unidas

PESTRAF - Pesquisa sobre Tráfico de Mulheres, Crianças e

Adolescentes para fins de exploração sexual comercial no Brasil

PNETP - Plano Nacional de Enfrentamento ao Tráfico de Pessoas

REDE LAC - Latino Americana de Enfrentamento ao Tráfico de Mulheres

SNJ - MJ - Secretaria Nacional de Justiça - Ministério da Justiça

UNFPA - United Nations Population Fund

UNODC - Escritório das Nações Unidas Contra Drogas e Crimes 


\section{Introdução}

O tráfico de pessoas é um crime de violação de direitos humanos cuja ocorrência acontece a partir da coação ou engano para o deslocamento através das fronteiras de um país para outro, mediante migração internacional, com a finalidade de exploração'.

A preocupação com o tráfico vem ocupando de forma crescente o debate internacional e nacional, principalmente a partir dos anos 90 e motivando a criação de documentos internacionais, bem como a revisão das legislações em diversos países, além de ações e políticas para o seu enfrentamento.

No Brasil, tal preocupação gerou não só mudanças na legislação penal, mas a criação de uma Política Nacional de Enfrentamento ao Tráfico de Pessoas.

Verificou-se também neste período um aumento de estudos e pesquisas, programas, campanhas e informações, objetivando uma maior sensibilização da população sobre a temática e convertendo o tráfico de pessoas em uma importante prioridade política (Laczko, 2002).

No entanto, de acordo com Bruckert (2002, p. 7-8), grande parte desses estudos sobre o tráfico de pessoas tem se limitado a descrever o fenômeno, indicando os distintos atores envolvidos, rotas, consequências e mecanismos para seu combate, sendo constatado por vários autores, a falta de estudos sistemáticos sobre o assunto e a ausência de um quadro teórico consistente que estruture a análise e a pesquisa sobre $o$ assunto.

Esses estudos e pesquisas são geralmente utilizados para subsidiar ações contra o tráfico, principalmente de mulheres, que aparecem como as principais vítimas.

Uma questão importante ao se trabalhar esse tema é a dificuldade de identificar a dimensão do fenômeno. Os números alarmantes de pessoas traficadas divulgados por órgãos internacionais ${ }^{2}$, sem explicitar a metodologia

\footnotetext{
${ }^{1} \mathrm{O}$ debate sobre o que se entende sobre exploração será retomado no próximo capítulo, quando se discutirá a definição do tráfico de pessoas contida no Protocolo de Palermo.

${ }^{2}$ Segundo o Relatório Global sobre Tráfico de Pessoas, divulgado pelo UNODC, em fevereiro de 2009 , mais de 2,4 milhões de pessoas são atualmente vítimas de tráfico para fins comerciais. A exploração sexual é a finalidade de maior incidência no tráfico de pessoas, com $79 \%$ dos casos; e a exploração laboral registra $18 \%$ das situações identificadas de tráfico de pessoas. Escritório das Nações Unidas sobre Drogas e Crime (UNODC), revelou que só na Europa existem cerca de 140
} 
utilizada para a obtenção desta informação, aponta para o perigo da criação de políticas ineficientes e inadequadas, a partir de dados imprecisos e não confiáveis.

Os números sobre o tráfico sexual, seja a nível nacional, continental ou mundial, dificilmente são sólidos e fiáveis, o que tem conduzido a duas posições que, por serem extremadas, efetivamente pouco podem ajudar as mulheres traficadas. Cada organização internacional presenteia-nos com números que podem divergir em milhares ou em milhões. Por um lado, temos instâncias que fazem referência a números muito elevados; por outro, aquelas que contestam esses números e que entendem que o tráfico sexual é um fenômeno residual. Ambas as posições comportam perigos. A primeira tem o perigo de negar aquilo que é a auto-determinação das mulheres, assumindo como tráfico situações de auxílio à imigração ilegal ou prostituição voluntária. A segunda comporta o perigo de não ajudar as mulheres que estão realmente em perigo (Santos; Boaventura et al, 2009, p.70).

Estes números alarmantes são reforçados pelas histórias de mulheres traficadas, que parecem quase como um padrão de vítima, que envolvem o engano, através de promessas falsas de casamento ou trabalho lucrativo, o deslocamento com a retenção do passaporte pelos criminosos, o aprisionamento, a prostituição forçada e a servidão por dívida.

A similaridade das narrativas presentes nesses estudos, a repetição contínua de imagens de mulheres capturadas e marcadas pela violência ajudam a construir um imaginário unificado e sem muitos questionamentos (Andrijasevic, 2004), reforçam estereótipos em relação à mulher que aparece como o grupo mais vulnerável à ação das organizações criminosas e que por isso seu deslocamento precisa ser tutelado pelo Estado.

Com base nestes estudos, que aparecem como "verdades" sobre o tráfico de pessoas, países no combate a este crime vêm promovendo ações de contenção ao trânsito de pessoas (negativas de concessão de visto, expulsão de "imigrantes" pela deportação) e controle das fronteiras, evitando a migração de milhares de homens e mulheres, em especial de países pobres que procuram nos países ricos melhores oportunidades de trabalho e de vida; principalmente se este deslocamento se der de forma irregular.

Apesar deste tema ainda ser pouco estudado pelos profissionais da área de serviço social - o que se reflete na escassez de produções acadêmicas e publicações sobre o assunto - no Brasil o tráfico de pessoas vem sendo pautado

mil mulheres vítimas do tráfico humano que servem àqueles que procuram o mercado da exploração sexual. Por ano também são feitas 70 mil novas vítimas do crime organizado para exploração sexual. Porém não é informado como se chegou a estes números. 
gradativamente, principalmente pelos profissionais que atuam no atendimento às mulheres, crianças e aos adolescentes em nosso país ${ }^{3}$, sendo identificado como uma violação de direitos humanos que precisa ser combatida.

A temática do tráfico para o serviço social, dentro de uma perspectiva crítica, pode ser entendida como uma nova expressão da questão social ${ }^{4}$, pois revela as desigualdades sociais e a ausência de perspectiva para as classes que vivem do trabalho nas sociedades capitalistas, que levam pessoas, na busca de melhores condições de vida e trabalho a serem enganadas ou coagidas e se submeterem à situações de exploração para trabalhos forçados, incluindo neste a servidão por dívida, o trabalho escravo e a exploração sexual ${ }^{5}$.

A defesa intransigente dos direitos humanos é parte integrante dos princípios que norteiam a ação do profissional de serviço social, sendo este um dos desafios colocado para a categoria profissional na consolidação de seu projeto ético-político: a concretude desses direitos para as populações excluídas de seu acesso em uma sociedade capitalista onde a desigualdade e a exploração do trabalho são intrínsecos à própria lógica do capital.

A primeira aproximação com este tema ocorreu em 2000, quando da participação como uma das pesquisadoras da PESTRAF - Pesquisa sobre tráfico de mulheres, crianças e adolescentes para fins de exploração sexual comercial no Brasil ${ }^{6}$, concluída e publicada em 2002.

O ingresso no Projeto Trama em $2004^{7}$, representando a universidade UNIGRANRIO, a militância no movimento de mulheres do Município de Duque

\footnotetext{
${ }^{3}$ Não se tem informações sobre como os profissionais de serviço social de outros países vem se apropriando deste tema.

${ }^{4}$ Segundo Marilda lamamoto - autora importante no serviço social brasileiro, por suas produções que aproximaram a profissão à teoria crítica marxista - "a questão social é apreendida como o conjunto das expressões das desigualdades da sociedade capitalista madura (2001: p.27)". E acrescenta: "A questão social não é senão as expressões do processo de formação e desenvolvimento da classe operária e de seu ingresso no cenário político da sociedade, exigindo seu reconhecimento como classe por parte do empresariado e do Estado. É a contradição entre o proletariado e a burguesia".(IAMAMOTO; CARVALHO, 1983:p.77)

${ }^{5}$ Cf. OIT - Organização Internacional do Trabalho. Relatório Global do seguimento da Declaração da OIT sobre Princípios e Direitos Fundamentais no Trabalho - 2001e 2005.

A PESTRAF, foi a primeira pesquisa de abrangência nacional realizada sobre o tema, coordenada internacionalmente pelo Instituto Internacional de Direitos Humanos da Faculdade de Direito da Universidade De Paul de Chicago, pelo Programa de Direitos Humanos da OEA, pela Comissão Interamericana de Mulheres e o Instituto Interamericano del Niño e, nacionalmente pelo CECRIA - Centro de Referência, Estudos e Ações sobre Crianças e Adolescentes, sendo concluída e publicada em 2002. Teve por objetivo, verificar a existência do tráfico de pessoas no Brasil, identificado rotas, perfil de aliciadores e vítimas, processos judiciais, rede de aliciamento, entre outros aspectos considerados relevantes sobre o tema. Cf. Leal, 2002.

7 O Projeto Trama é constituído por um consórcio de quatro instituições não governamentais: CRIOLA - organização de mulheres negras; IBISS - Instituto de Inovações em Saúde Social; Organização de Direitos Humanos Projeto Legal e a Universidade UNIGRANRIO. O Projeto Trama surgiu em 2004 e atualmente participa da rede de articulação nacional e internacional, através da Rede LAC - Rede Latino Americana de Enfrentamento ao Tráfico de Mulheres e GAATW Brasil e Internacional, denominada Aliança Global de Enfrentamento ao Tráfico de Mulheres.
} 
de Caxias na Baixada Fluminense desde 2000 e, a atuação como assistente social do Núcleo de Prática Jurídica da UNIGRANRIO no atendimento e acompanhamento às mulheres em situação de violência, principalmente doméstica, possibilitou uma reflexão continuada sobre a temática do tráfico de pessoas, levando a escolha deste tema como objeto de estudo no doutorado.

O tráfico ganha uma nova dimensão na contemporaneidade se associado às mudanças econômicas e sociais, acentuadas com a crise do capitalismo a partir dos anos de 1970, levando a expressivas alterações nos processos e no mercado de trabalho, com o gradativo desmantelamento dos sistemas de proteção social em diversos países e a efetiva perda de direitos sociais, acompanhada da redução da ação do Estado nas relações sociais e de produção.

Os projetos que marcaram a modernidade numa perspectiva socialdemocrata dão lugar à perda de direitos sociais historicamente conquistados, num retrocesso das conquistas democráticas frente ao avanço neoliberal.

$\mathrm{Na}$ contemporaneidade, cada vez mais a afirmação dos direitos fundamentais do ser humano adquire relevância, diante das profundas mudanças ocorridas na ordem econômica mundial com a reestruturação produtiva pela acumulação flexível.

O aprofundamento das desigualdades sociais, gerado por estas mudanças no processo produtivo, fará crescer o desemprego estrutural, os níveis de pobreza extrema que passam a atingir grandes contingentes populacionais no mundo, que, sem perspectiva de inserção em postos de trabalho mais estáveis e menos precários, encontrarão no trabalho informal, parcial, temporário, precário e subcontratado um meio de sobrevivência.

É neste contexto de precarização das condições de vida e de trabalho, que populações intensificarão seus deslocamentos pelo mundo, a partir da década de 1980, saindo principalmente dos países do chamado Terceiro Mundo para aqueles de Primeiro Mundo, invertendo o fluxo migratório das décadas anteriores, à procura de novas oportunidades.

Contraditoriamente, frente à intensificação dos fluxos migratórios, países que se tornaram os principais receptores vêm restringindo cada vez mais a entrada de migrantes, com o enrijecimento das legislações migratórias. Estas restrições são justificadas também pela proteção aos direitos humanos de 
migrantes que cada vez mais aparecem como vítimas das ações do tráfico de pessoas ou de contrabandistas que facilitam a entrada irregular no país de destino. Entretanto, de acordo com diversos estudiosos sobre o tema ${ }^{8}$, as próprias restrições de entrada de migrantes nos países de destino facilitam a ação destes grupos criminosos.

A articulação entre as temáticas do tráfico de pessoas, com a migração internacional neste estudo, possibilita ampliar o tratamento da questão do tráfico, situando-o não mais como um fenômeno isolado. Ao contrário, ele ganha nova dimensão quando pensado dentro dos processos migratórios contemporâneos, no contexto da reestruturação produtiva, que impulsionam milhares de pessoas a se deslocarem pelo mundo à procura de melhores oportunidades de vida e trabalho.

Esta visão mais ampla permite como se verá, a compreensão de aspectos econômicos, políticos, culturais e sociais que favorecerão a existência e permanência do tráfico, principalmente de mulheres.

A mulher sempre esteve presente nos processos migratórios, porém sua presença foi subestimada como sujeito social relevante, sendo vista como participante passiva nos projetos migratórios tidos tipicamente como masculinos.

Contudo, nos últimos anos, é crescente a visibilidade das mulheres nos processos migratórios, assim como de sua importância neste, podendo ser um indicativo de maior autonomia ou emancipação destas mulheres nestes processos.

Para Magliano e Domenech (2008), apesar da maior visibilidade da mulher como sujeito social relevante nos discursos e recomendações na agenda global e regional sobre migrações, isso não tem modificado de forma considerável os processos históricos que produzem e reproduzem as desigualdades de gênero e que condicionam as realidades migratórias femininas.

Tradicionalmente a migração feminina é associada à reunificação familiar, porém, com as mudanças na estrutura produtiva e no mercado de trabalho, e com a crescente incorporação da força de trabalho feminina em diversos setores da economia, cada vez mais mulheres migram à procura de oportunidades de trabalho, sozinhas ou com a família. Contudo, estas oportunidades de inserção no trabalho vêm se dando em sua maioria em ocupações com baixa

\footnotetext{
${ }^{8}$ Cf. Martine(2005); Kempadoo (2005); Anderson e O'Connell Davidson(2004), Peixoto (2007), Donnan e Wilson(1999), Kapur (2005).
} 
remuneração e em condições precárias, com pouca ou sem nenhuma garantia de direitos trabalhistas.

A intersecção dos temas migração feminina e o tráfico de mulheres, permite visualizar a existência de certos mecanismos que "tornam" a mulher vulnerável no processo migratório e por isso, objeto de tutela pelos países de destino e de origem quando em deslocamento. Isso também explica a ênfase dada por diversos países ao tráfico de mulheres para fins sexuais, em detrimento da abordagem de outras modalidades de tráfico, envolvendo inclusive homens e transgêneros.

A questão da "vulnerabilidade das mulheres" é colocada em diversos discursos e documentos internacionais, onde as mulheres aparecem identificadas como "grupo vulnerável", em detrimento do reconhecimento de aspectos positivos de sua migração e sem esclarecer o que quer dizer esta classificação.

A concepção de vulnerabilidade associada às migrações femininas tem revelado como a própria natureza das diferenças sexuais é dotada de significado social, naturalizando e reproduzindo estereótipos sociais (Stolcke, 1999), enfatizando aspectos que reforçam a ideia de subjugação derivada da condição feminina, que expõe esta mulher quando em mobilidade.

La creencia de que no deciden sobre su propia movilidad y que son más propensas a ser "abusadas" y "explotadas" hace que sean descritas como víctimas hacia las que se despiertan sentimientos de protección y compasión que, según considera Juliano(2002), es otra forma de estigmatización y segregación social. Esta perspectiva que asocia a la mujer migrante a los grupos vulnerables por el hecho de ser mujer, haciendo hincapié en su pasividad y debilidad a la hora de explicar sus desplazamientos, se apoya en aquellas posturas que naturalizan conductas y roles socialmente establecidos para hombres y mujeres, y no toma en cuenta las distintas estrategias desplegadas por las propias mujeres migrantes para modificar sus trayectorias de vida (Magliano \& Domenech, 2008, p. 56).

Neste sentido verifica-se a existência de uma moralização ${ }^{9}$ em relação à migração feminina, que vem gerando constrangimentos e cerceamento dos direitos de mulheres quando em deslocamento, justificando inclusive o impedimento de entrada nos países, a deportação ou a permanência nos países de destino sem nenhuma garantia em termos de direitos.

\footnotetext{
${ }^{9}$ Segundo o Dicionário Aurélio, a palavra moralizar significa conformar aos princípios de uma determinada moral, sendo esta um conjunto de regras consideradas como válidas quer universalmente (de modo absoluto para qualquer tempo ou lugar), quer para o grupo ou pessoa determinada. Dicionário Aurélio on-line, disponível em: http://www.dicionarioaurelio.com.
} 
Tais situações enfatizam aspectos que reforçam a ideia de subjugação derivada da condição feminina, que expõe esta mulher quando em mobilidade, principalmente em condições que a identifiquem com a prostituição e com a imigração irregular.

Tal concepção confronta-se com o reconhecimento da autonomia e do protagonismo destas mulheres no processo migratório, que é visto como um aspecto negativo ou de risco, quando há a suspeita do envolvimento de mulheres na indústria do sexo ou pela possibilidade de se tornarem imigrantes irregulares. Assim as mulheres são colocadas ora como vítimas ora como subversivas. Tidas como "estrangeiras", "imorais", "perigosas", "inferiores", "socialmente e economicamente excluídas".

Para além das ações de restrição à migração, muitas nações, com base em argumentos morais, defendem a abolição da prostituição, justificando que esta é que gera o tráfico de mulheres, não fazendo distinção entre prostituição forçada e voluntária, e criminalizando aqueles que consomem ou contribuem de alguma forma para a existência da prostituição. Nesta lógica, eliminando-se a prostituição consequentemente se acabaria com o tráfico.

É certo que, dependendo da abordagem que se tenha sobre o tráfico, diferentes serão as estratégias implementadas para o seu enfrentamento. Além disto, aspectos econômicos, sociais, políticos e culturais influenciarão na forma como os diversos países irão atuar com esta problemática.

Há que se ressaltar que estudos recentes sobre o comércio sexual ${ }^{10}$ vêm contrapondo e criticando algumas concepções sobre o tráfico sobretudo aquelas que não distingue o tráfico da prostituição voluntária e apresentam sempre a imagem da mulher envolvida com o mercado sexual como decaída, vítima do tráfico e capturada pelo mercado sexual.

A esta imagem da mulher vítima presente nestes estudos é contraposta a figura de mulheres envolvidas neste mercado como sujeitos atuantes, autodeterminados, capazes de negociar, concordar ou opor-se e transformar relações de poder. Essas pesquisas sugerem que pessoas envolvidas em processos migratórios, mesmo aquelas envolvidas no mercado transnacional do sexo, não são somente submissas e passivas, mas também são pessoas aptas a fazer escolhas e tomar decisões capazes de levar a transformações conscientes que mudam suas vidas.

\footnotetext{
${ }^{10}$ Ver entre outros: Piscitelli, 2007; Kempadoo, 1998; Blanchette e Silva, 2005.
} 
Esta questão, porém, está longe de ser um consenso no debate público atual sobre o tráfico de mulheres para fins sexuais.

A complexidade desta temática se evidencia pelas contradições, ambiguidades e lacunas na tentativa de construir-se uma concepção que melhor defina o que seja o tráfico de pessoas na atualidade, o que passa também pelos diferentes interesses em disputa no âmbito internacional.

Dentre as contradições existentes está o fato de que no desenvolvimento de ações que visem à proteção de pessoas traficadas, se acabe violando outros direitos, tais como, da liberdade de ir e vir, pela restrição da migração de pessoas e da liberdade sexual, com ações de intolerância e repressão aos migrantes, em especial os irregulares e aqueles envolvidos na indústria do sexo, que exercem a prostituição voluntária, como se esta fosse a causa do tráfico para fins sexuais.

Sem negar a existência do tráfico, especificamente de mulheres, e, afirmando-o como uma violação de direitos humanos, acredita-se que muitos países vêm utilizando argumentos moralizantes em relação à migração feminina, sem contudo garantir a real proteção dos direitos dessas mulheres que venham a se encontrar em situação de tráfico ou de outras formas de violação e de violência no processo migratório.

O uso da categoria gênero neste estudo justifica-se não apenas porque se falará de mulheres, mas para melhor compreensão da produção das desigualdades que marcam as relações entre masculino e feminino, e como estas construções sociais serão apropriadas e reproduzidas na dinâmica da migração feminina e do tráfico de pessoas, bem como nas ações anti-tráfico através inclusive de campanhas vinculadas pela mídia em diversos países.

O discurso anti-tráfico é então utilizado com o objetivo de exercer o controle sobre este deslocamento, sem que haja uma real e efetiva preocupação com a proteção desta mulher. Tal visão confronta-se com o reconhecimento da autonomia e do protagonismo destas mulheres no processo migratório, que é visto como um aspecto negativo (infratoras) ou de risco (vítimas).

Neste sentido pretende-se diante da complexidade deste tema, analisar os nexos existentes entre a condição de gênero das mulheres, o tráfico de mulheres e a mobilidade feminina através da migração internacional, procurando discutir certas afirmações recorrentes sobre o tráfico, mediante a análise de conceitos e ações impetradas atualmente no seu enfrentamento.

Para tanto, em termos metodológicos, utilizou-se da pesquisa bibliográfica e documental e, da pesquisa de campo, realizada mediante 
entrevistas com organizações públicas e não governamentais que atuam no enfrentamento ao tráfico de pessoas no Rio de Janeiro, além de entrevistas com mulheres que tiveram experiência de migração internacional e relataram suas histórias de vida, o que possibilitou também a construção de um perfil sociológico destas mulheres.

Este estudo está dividido em quatro capítulos.

O primeiro capítulo abre o estudo com a problematização sobre a conceituação do tráfico de pessoas na atualidade, trazendo as ambiguidades e interesses em disputa neste processo.

Este capítulo procura historiar este conceito e acompanhar como o tráfico irá se configurar em diferentes contextos históricos, influenciado por fatores políticos, econômicos e culturais de cada época, passando de uma prática legalizada e de produção de riqueza para muitas nações a uma prática repudiada por envolver mulheres brancas europeias inseridas na prostituição, até a concepção atual contida no Protocolo de Palermo (2002).

Apresenta também a legislação brasileira sobre o assunto, a fim de verificar como o Brasil, ao ratificar diversos documentos internacionais, incorporou a tipificação do tráfico em sua legislação interna. Além da legislação propriamente dita, este item será enriquecido pelo material de entrevistas realizadas em julho de 2011, com representantes de instituições sediadas no Rio de Janeiro que atuam com a temática do tráfico de pessoas.

As entrevistas foram realizadas com uma representante do Consórcio Trama, e outra, com representante do Núcleo de Enfrentamento ao Tráfico de Pessoas do Rio de Janeiro, com atuações a nível nacional e regional, respectivamente e que farão o contraponto entre o legal e o real, a partir das experiências institucionais no enfrentamento ao tráfico de pessoas.

O segundo capítulo, articula o tráfico à temática de gênero, resgatando os debates do movimento feminista ao longo de sua história e sua contribuição na problematização do tráfico de mulheres.

$\mathrm{Na}$ atualidade, a existência de divergências dentro do movimento feminista leva ao confronto de dois grupos, divididos em grandes coalizões internacionais. Tais grupos possuem concepções distintas sobre prostituição e tráfico, tendo como pano de fundo, visões morais que se sustentam em bases epistemológicas opostas, conduzindo a diferentes implicações políticas sobre o assunto. 
Ao final do capitulo se analisará as campanhas anti-tráfico promovidas por diversos países, identificando através das imagens publicitárias como as relações de gênero e o tráfico se configuram nestas campanhas.

O terceiro capítulo dimensiona o tráfico de pessoas como um crime que ocorre no contexto da migração internacional, distinguindo-o do contrabando de migrantes, e enfatizando as especificidades da migração feminina num contexto de significativas mudanças econômicas e políticas ocorridas em nível mundial, refletindo sobre o que tem levado diversos países a restringir suas fronteiras e enrijecer suas legislações em relação aos imigrantes.

Por fim, o último capítulo é dedicado à contextualização da pesquisa e à análise dos relatos das histórias de vida de cinco mulheres brasileiras, que migraram em algum período de suas vidas e retornaram ao Brasil.

Esta pesquisa de cunho qualitativo, realizada entre janeiro a julho de 2011, procurou analisar a percepção destas mulheres quanto a sua motivação para migrar, a sua permanência no país de destino e o seu retorno ao Brasil. Todas as entrevistadas identificam em suas histórias, situações de violação de direitos humanos, inclusive de tráfico, bem como apontam os sujeitos participantes e suas ações (Estado, organizações da sociedade civil, família, amigos, grupos criminosos entre outros) e as estratégias que foram por elas utilizadas na superação das dificuldades e nas interrupções das violações.

Sem a pretensão de generalizar o conhecimento produzido a partir das histórias particulares dessas mulheres, se reconhece, no entanto, que estes relatos também informam as relações e contextos sociais mais amplos em que estas estão inseridas. 


\section{2 \\ O Tráfico Internacional de Pessoas}

O tráfico internacional de pessoas vem ocupando de forma crescente o debate internacional e nacional, principalmente a partir dos anos 90, expressando uma grande preocupação de Estados-Nação, de organizações da sociedade civil e instituições supranacionais ${ }^{11}$.

Este crime de violação de direitos humanos, na contemporaneidade, ganha nova dimensão com as desigualdades socioeconômicas das diferentes regiões do mundo, com os fluxos migratórios, com o fechamento das fronteiras e com enrijecimento da legislação migratórias dos países considerados receptores, seja pela necessidade de proteção dos direitos humanos das pessoas traficadas ou, pela preocupação com a imigração irregular (Alencar, 2007).

Nesse capítulo pretende-se trazer a complexidade desta temática e o caminho percorrido, repleto de conflitos e polêmicas, para se chegar a uma conceituação que melhor defina o tráfico de pessoas na atualidade, mesmo que ainda não haja definições consensuais.

Os dissensos e as lacunas que ainda permanecem, permitem que cada país interprete tais conceitos conforme o ordenamento jurídico interno.

A legislação brasileira de combate ao tráfico de pessoas será analisada posteriormente, mostrando como o Brasil vem tratando esta situação em sua normatização jurídica, e, como esta se operacionalizará na realidade, cuja melhor compreensão só foi possível a partir da pesquisa de campo realizada junto às instituições que atuam com o tráfico de pessoas no Rio de Janeiro.

\footnotetext{
${ }^{11}$ A Organização das Nações Unidas (ONU), é uma destas instituições, como também o Fundo Monetário Internacional (FMI), Organização Mundial do Comércio (OMC). Criadas após a Segunda Guerra Mundial, essas instituições surgem com o entendimento de que os direitos, deveres e condições socioeconômicas dos países não podem mais ser vistos como problemas isolados. Já que influenciam a ordem global, precisam de alguns mecanismos para serem regulados globalmente. Surge assim uma nova forma de governança do território, através de organismos internacionais, trazendo um debate sobre a viabilidade de um governo supranacional. Disponível em: http://www.comciencia.br/reportagens/2005/07/06.shtml
} 


\title{
2.1 \\ Percurso histórico na construção do conceito de Tráfico de pessoas
}

De acordo com o Dicionário Aurélio ${ }^{12}$, o termo tráfico significa um comércio ou negócio ilegal.

$\mathrm{Na}$ atualidade o termo é utilizado para descrever crimes transnacionais como o tráfico de drogas, armas, de pessoas, animais, além de outros; que envolve atividades criminosas complexas, que adquiriram proporções alarmantes no contexto da mundialização do capital.

Em relação ao surgimento do tráfico de pessoas, há um grande número de referências que apontam o século XIX como aquele onde emerge uma grande preocupação e um pânico moral, a partir dos EUA e da Europa, com o tráfico de "escravas brancas" , ou seja, o tráfico de mulheres europeias trazidas para as Américas com a finalidade de serem exploradas sexualmente.

É sabido que o tráfico de pessoas não surgiu no séc. XIX. Alguns autores, que se dedicam ao estudo do tráfico para fins de trabalho escravo na contemporaneidade, fazem referência às origens do tráfico de pessoas, às práticas do tráfico de escravos, tanto na Antiguidade greco-romana quanto na modernidade com a escravidão de povos africanos nas Américas, ressaltando, porém, que, em comparação com a escravidão contemporânea, há de se observar que são fenômenos diferenciados.

\begin{abstract}
(...) há diferenças substantivas entre a escravidão extinta em 1888 e as novas formas de escravismo. A escravidão estava definida pelo costume e pela lei e ganhava sentido no fato de que legalmente o cativo era uma mercadoria. $\mathrm{Na}$ nova situação, o peão pode se tornar ou não uma mercadoria. Isto depende de circunstâncias locais e setoriais. Portanto, a peonagem não é uma instituição. Fato que dificulta a sua compreensão quando se põe a ênfase no aspecto meramente conceitual do problema (Martins, 1994, p,13-14).
\end{abstract}

Com a expansão marítima dos Estados europeus na conquista de terras pelo mundo, posteriormente transformando-as em colônias, o tráfico de pessoas para o trabalho escravo constituiu-se em uma prática legal, admitida pelas nações em expansão por ser fonte produtora de enriquecimento para estas. Em nome da dominação colonial, populações indígenas, africanas e outros povos foram aniquilados e/ou escravizados.

\footnotetext{
${ }^{12}$ Dicionário Aurélio on-line, disponível em: http://www.dicionarioaurelio.com/
} 
O sentido geral do expansionismo europeu estava nas práticas mercantilistas, desenvolvendo várias formas de acumulação de capital, acelerando a transição do feudalismo para o capitalismo.

A escravidão era duplamente lucrativa, ao nível da circulação da mercadoria humana, permitindo a acumulação por parte da burguesia traficante e ao nível da produção. O trabalho escravo sustentava a classe dominante colonial e, em parte, as classes dominantes metropolitanas interessadas no pacto colonial, além de permitir 0 assalariamento de trabalhadores especializados, o que fornecia recursos para a renovação dos meios de trabalho e para a continuidade do tráfico.

Esta escravidão legalizada conviveu no século XIX com a preocupação moral e política com o tráfico de escravas brancas (mulheres que seriam capturadas e levadas para trabalharem como prostitutas), trazidas para as colônias junto com grandes fluxos migratórios ocorridos naquele período.

Assim a primeira ideia sobre o tráfico surge não pelo repúdio à escravidão de homens e mulheres, negros africanos - uma vez que eram tidos como "coisas" e com tais, não eram vistos como seres humanos, mas como objeto/ mercadoria - mas a partir da necessidade do controle do corpo e da sexualidade da mulher branca europeia, migrante, diante da ameaça, causada pela liberação e autonomia das mulheres, aos valores e interesses sociais, revelando uma moralização da migração quando se trata do deslocamento deste grupo.

De acordo com Doezema (2000), são os medos e temores da sociedade europeia e americana a respeito de mudanças sociais que enfatizarão o papel das narrativas do tráfico de escravas brancas. Tais medos referiam-se não só à sexualidade e à independência feminina, mas também ao receio dos estrangeiros e dos migrantes.

O pânico moral causado pelas histórias de tráfico de escravas brancas propiciará nos séculos seguintes o surgimento de legislações e políticas de combate a este tipo de tráfico, a princípio especificamente de meninas e mulheres brancas, para posteriormente, evoluir para a concepção de tráfico de pessoas.

É no começo do século XX que o direito internacional irá se ocupar com a questão do tráfico da escrava branca. 
Os esforços organizados, em nível internacional, para o combate ao tráfico de pessoas iniciam-se com a Conferência de Paris em $1902^{13}$, havendo estabelecido o primeiro acordo internacional visando à repressão ao tráfico de pessoas.

O Acordo Internacional para a Supressão do Tráfico de Escravas Brancas, elaborado pela Liga das Nações ${ }^{14}$ e concluído em Paris, em 18 de maio de 1904, foi o primeiro instrumento legal com objetivo de combater o recrutamento e o abuso de mulheres e meninas para finalidades imorais no exterior (Derks, 2000).

Esse documento tratava do aliciamento de mulheres para serem prostituídas no estrangeiro e não faz referência a nenhum tipo de consentimento dado por elas como também não se refere ao uso de força, coação, engano ou outra prática fraudulenta para convencer ou obrigar as mulheres a se inserirem na prostituição em outros países.

Pelo documento, os governos se obrigavam a designar um agente responsável por investigar os casos de aliciamento, bem como a estabelecer serviços de vigilância para descobrir os indivíduos que acompanhavam essas mulheres. Deviam também informar às autoridades competentes do lugar de destino, aos agentes consulares ou diplomáticos interessados ou a qualquer autoridade competente.

Ademais, havia ainda o compromisso dos governos exercerem vigilância sobre as agências que se ocupavam da colocação de mulheres no estrangeiro.

No que se refere à proteção, o Acordo é vago e impreciso, fazendo referência apenas à possibilidade dada aos governos de confiarem essas mulheres a instituições de assistência pública ou privada ou ainda a particulares que oferecessem as necessárias garantias às vítimas do tráfico, quando elas não possuíssem recurso.

\footnotetext{
13 Ressalta-se que, anteriormente a esta, já haviam sido organizadas outras Conferências Internacionais com o propósito de combater o tráfico de escravas brancas, sendo a primeira delas ocorrida em Paris (1895), seguido pelas de Londres e Budapeste. A mencionada conferência em Londres, em 1899, proporcionou a criação da Associação para a Repressão ao Tráfico de Escravas Brancas, sediada também em Londres. (Cf. Long, 2004: p.20; De Vries,2005: p.50).

${ }^{14}$ Os países presentes nesta Conferência: França, Alemanha, Grã Bretanha, Itália, Rússia, Suíça, Suécia, Noruega, Dinamarca, Bélgica, Holanda, Espanha e Portugal. Mais tarde se juntaram a convenção também Áustria-Hungria, EUA e Brasil (Cf. Long, 2004,p20; De Vries, 2005, p.51; Moura Gomes, 2005, p.230).
} 


\begin{abstract}
Art. $3^{\circ}(\ldots)$
Os Governos se obrigam, dentro dos limites legais e tanto quanto possível, a confiar, a título provisório, e tendo em vista a eventual repatriação, a instituições de assistência pública ou privada ou a particulares que ofereçam as necessárias garantias às vítimas desse tráfico, quando elas se achem desprovidas de recurso.
\end{abstract}

Os governos ainda se obrigavam a repatriar essas mulheres quando elas o solicitassem ou quando fosse solicitado por pessoas que sobre elas possuíssem autoridade, devendo os países envolvidos facilitar o trânsito em seus territórios. As despesas com a repatriação, segundo se depreende no artigo $4^{\circ}$, deveriam correr por conta da mulher, de algum familiar ou responsável e, somente quando isso não fosse possível, seriam rateadas pelos países de origem e de destino.

Essa conferência que elaborou o Acordo Internacional para a Supressão do Tráfico de Escravas Brancas em 1904, centrou-se no tráfico de mulheres brancas, não incluindo mulheres traficadas de outras raças, como a negra.

Em 1910 a Convenção Internacional para a Supressão do Tráfico de Escravas Brancas, conhecida como Convenção de Paris, teve por objetivo a construção de uma política comum para "combater o abuso e a coação de mulheres e meninas brancas para fins imorais", punindo os traficantes, caso fosse utilizada a força ou a fraude. Em relação ao Acordo, a Convenção diferencia-se por reconhecer que a ação do tráfico de pessoas não implica necessariamente em cruzar fronteiras (Derks, 2000).

Nesta Convenção já se verifica a inclusão da questão do consentimento e a distinção que se faz entre o tráfico de mulheres menores e adultas. Eis que, quando se tratar de meninas, o consentimento porventura dado será irrelevante, enquanto que, ao se referir a mulheres maiores, claramente destaca a necessidade da presença de meios coercitivos que submetam a mulher a um propósito considerado imoral.

Destaque-se que o acordo de 1904 vinculava o tráfico de mulheres para a finalidade da prostituição, enquanto a Convenção de 1910 se referia a propósitos imorais, sob cuja expressão poderiam ser incluídas diversas atividades assim consideradas.

Porém, tanto o Acordo como a Convenção limita-se à primeira parte do tráfico, ou seja, ao recrutamento e aliciamento da pessoa, não tratando do resgate da mulher captada contra a própria vontade. Assim, o resgate de uma 
mulher submetida à situação de prostituição contra a sua vontade, em um bordel, por exemplo, seria assunto de legislação nacional ${ }^{15}$.

Outro aspecto que também foi ignorado neste documento refere-se ao consentimento imoral e fraudulento, já que a anuência de mulheres casadas ou solteironas maiores de idade descriminalizavam a conduta ${ }^{16}$.

De acordo com Doezema (2000), é possível verificar uma preocupação moral subjacente que está relacionada com perspectivas conservadoras com respeito à autonomia e à sexualidade feminina, que representam alvo de críticas atuais.

É somente com a Convenção Internacional para a Supressão do Tráfico de Mulheres e Crianças de 1921, promovida pela Liga das Nações em Genebra, que amplia-se incluindo crianças (independente do sexo) e elimina-se a conotação racial, retirando o termo "tráfico de escravas brancas".

Apesar da Convenção de 1910 já fazer referência ao tráfico de mulheres menores, sendo estas consideradas com idade abaixo de vinte anos, o novo documento faz menção expressa à repressão ao tráfico de crianças.

\begin{abstract}
Artigo 2 - Às Partes principais contratantes convém tomar todas as medidas em vista de investigar e punir os indivíduos que se ocupem do tráfico de crianças de um ou de outro sexo, esta infração seja entendida dentro do sentido do artigo primeiro da convenção de 4 de maio de 1910.
\end{abstract}

O documento destaca as medidas para investigar e punir os envolvidos com o delito, mas é também expresso no que se refere à punição da tentativa e, dentro dos limites legais, dos atos preparatórios ao tráfico de mulheres e crianças.

Artigo 3 - Às partes principais contratantes convém tomar as medidas necessárias em vista de punir as tentativas de infrações e, dentro dos limites legais, os atos preparatórios de infrações previstos nos artigos 1 e 2 da convenção de 4 de maio de 1910.

Como as Convenções anteriores, a de 1921 não prevê medidas que se destinem à proteção e assistência das vítimas do tráfico, fazendo referência apenas à repressão e punição dos envolvidos nessa prática e nos acordos de extradição entre os Estados.

\footnotetext{
${ }^{15}$ Cf. De Vries, 2005; Derks,2000.

${ }^{16}$ Cf. Wijers ; Lap-Chew apud De Vries, 2005, p.52; Wijers ; Lap-Chew apud Doezema, 2002,p.23.
} 
Em 1933, na Convenção para a Repressão do Tráfico de Mulheres Maiores, realizada em Genebra, a noção da coação da pessoa traficada, elemento recorrente nos tratados anteriores, desaparece no texto dessa convenção.

Com essa Convenção criminalizou-se o recrutamento com o objetivo de exploração da prostituição, mesmo que tenha havido o consentimento da vítima; prevalecendo assim o viés abolicionista sobre as tendências regulacionistas que passa a ser adotado pelas legislações locais (Doezema, 2002).

Em 1945, após a II Guerra Mundial, é criada a Organização das Nações Unidas, extinguindo a Liga das Nações. Com isso foi elaborado o Protocolo de Emenda da Convenção para a Repressão do Tráfico de Mulheres e Crianças, concluído em Genebra, a 30 de setembro de 1921, e da Convenção para a Repressão do Tráfico de Mulheres Maiores, concluída em Genebra, a 11 de outubro de 1933.

Tais documentos não trouxeram nenhuma inovação substancial em relação aos anteriores e foram elaborados apenas com o objetivo de ratificar dispositivos antes existentes que se referiam à Liga das Nações, consistindo em uma adaptação à nova organização à qual estariam vinculados.

Em 1949, a ONU promulga a Convenção para a Supressão do Tráfico de Pessoas e do Lenocínio, eliminando a referência explícita às mulheres como objetos do tráfico e substituindo pelo termo pessoas, incluindo-se pela primeira vez os homens como também possíveis vítimas do tráfico. A Convenção contudo, continua a evocar a antiga relação entre prostituição e tráfico (Uçarer, 1999).

A Convenção não menciona tráfico para nenhum outro propósito, a não ser para a finalidade de exploração sexual, adotando a perspectiva de controle do crime de tráfico como prostituição, sem distinção da prostituição voluntária, criminalizando desta forma todas as atividades associadas esta atividade.

(...) é evocada a antiga relação entre tráfico e prostituição, construindo uma imagem de indistinção entre as duas atividades. A condenação ao tráfico é combinada com a condenação explícita da prostituição, considerando as duas práticas "incompatíveis com a dignidade e o valor da pessoa ", pois colocariam em perigo "o bem estar do indivíduo, da família e da comunidade" (Ausserer, 2007, p.36-37). 
A Convenção assume uma perspectiva abolicionista da prostituição, ocasionando a sua não aceitação por muitos países.

No intervalo de tempo entre 1949 e o ano 2000 não se verifica a edição de outro documento internacional voltado à ampla prevenção e combate do tráfico de pessoas. Apesar disso, consolidava-se na ONU o pensamento de garantia dos direitos humanos, em especial dos direitos das mulheres através da realização de conferências voltadas ao tema de direitos humanos e proteção da mulher, como a Conferência Mundial das Nações Unidas sobre Direitos Humanos (Viena, 1993) e a Conferência Mundial sobre a Mulher (Beijing, 1995).

\begin{abstract}
A Conferência Mundial das Nações Unidas sobre Direitos Humanos é de grande importância no atinente ao assunto, uma vez que contribuiu para a atual conceituação e destaque dos direitos humanos, afirmando sua universalidade de indivisibilidade. No mesmo sentido, a Conferência Mundial sobre a Mulher de Beijing, dirigiu-se aos aspectos referentes à questão de gênero e ações dos Estados para proteção e punição da violência contra a mulher. Com isso, conclui-se que tanto na Conferência realizada em Viena em 1993 quanto na Conferência de Beijing de 1995, há cooperação com a consolidação da ideia de que o tráfico de pessoas opõe-se a garantia dos valores fundamentais da pessoa humana, devendo, assim, serem tomadas medidas eficazes para o seu combate (Jesus, 2003, p. 30-31).
\end{abstract}

É no ano 2000 na cidade de Palermo que surgirá, através da Convenção contra o Crime Organizado Transnacional da ONU, o Protocolo para Prevenir, Reprimir e Punir o Tráfico de Pessoas, especialmente Mulheres e Crianças (Protocolo de Palermo) que proporá uma conceituação do tráfico de pessoas, ratificada por diversos países, e, que encontra-se ainda vigente. Tanto a Convenção como seu referido Protocolo terão uma abordagem mais aprofundada no próximo item deste capítulo.

Em 2005, no seguimento da Convenção das Nações Unidas acima mencionada, é promulgada no âmbito da União Europeia, a Convenção contra o Tráfico de Seres Humanos do Conselho da Europa ${ }^{17}$, assinada em Varsóvia. Esta convenção acompanha o conteúdo do Protocolo de Palermo, porém sua

\footnotetext{
17 A Convenção do CE sobre o Combate ao Tráfico de Seres Humanos (Council of Europe Covention on Action against Trafficking in Human Beings) foi adotada em Varsóvia (Polónia), em 16 de Maio de 2005 (online: http://www.coe.int/t/dg2/trafficking/campaign/Docs/Convntn/default_en.asp). Países que ratificaram a Convenção de Varsóvia: Albânia, Andorra, Armênia, Áustria, Azerbaijão, Bósnia e Herzegovina, Bulgária, Croácia, Chipre, República Checa, Dinamarca, Estónia, Finlândia, França, Geórgia, alemão, Grécia, Hungria, Islândia, Irlanda, Itália, Letônia, Lituânia, Luxemburgo, Malta, Montenegro Mol, Países Baixos, Noruega, Polónia, Portugal, Romênia, San Marino, Sérvia, Eslováquia, Eslovénia, Espanha, Suécia, Suíça, a antiga República lugoslava da Macedónia, Ucrânia, Reino Unido.Disponível:

http://www.conventions.coe.int/Treaty/Commun/ChercheSig.asp?NT=197\&CM=1\&DF=\&CL=E Acesso em: 01/03/2013.
} 
relevância esta no fato de ser o primeiro documento internacional que contém uma clara definição de vítima de tráfico com uma acentuada relevância na questão dos direitos humanos.

Traz como finalidade a prevenção e o combate ao tráfico de seres humanos, garantindo a igualdade entre mulheres e homens; a proteção aos direitos humanos das vítimas de tráfico, estabelecendo um quadro completo de proteção e de assistência às vítimas e às testemunhas; a promoção da cooperação internacional no domínio da luta contra o tráfico de seres humanos.

Esta convenção justifica-se tendo em vista que os Estados membros da União Europeia adotavam medidas essencialmente de carácter repressivo e desenvolviam políticas de imigração meramente punitivas, quando se abordavam as questões do tráfico. Com uma visão focada na relevância das vítimas de tráfico enquanto testemunhas em processos jurídicos.

Neste sentido a proposta da Convenção de Varsóvia enfatiza a perspectiva de direitos humanos, não circunscrevendo o tráfico de seres humanos simplesmente a um problema de migração, de ordem pública ou de crime organizado.

\section{2 \\ O Protocolo de Palermo}

Em 15 de novembro de 2000, a Assembleia Geral das Nações Unidas adotou a Convenção contra o Crime Organizado Transnacional objetivando prevenir e combater delitos transnacionais cometidos por grupos organizados.

Essa convenção representa o primeiro instrumento internacional contra o crime organizado transnacional e teve por objetivo promover a cooperação entre países para prevenir e combater o crime organizado de forma mais efetiva (artigo $1^{0}$ da Convenção). Em seus 41 artigos tratam dos seguintes temas: a criminalização da lavagem de dinheiro e de corrupção; a cooperação internacional para a confiscação; a extradição de criminosos; o intercâmbio de informações, de assistência legal e de técnicas de investigação; assistência e proteção de testemunhas e vítimas; e a prevenção de crimes (UNODCEscritório das Nações Unidas contra Drogas e Crimes). 
Esse documento foi complementado por dois protocolos, um dos quais versa sobre o contrabando de migrantes e o outro sobre o tráfico de pessoas.

Foi criado um comitê especial intergovernamental, que discutiu e negociou esses documentos, composto por representantes governamentais dos Estados e por ONG's, sendo acompanhados por uma comissão da ONU.

Os representantes de governos defendiam um maior rigor no combate ao crime organizado, no controle maior de documentos de migrantes e na proteção das fronteiras contra a migração irregular. As ONG's destacaram a adequada proteção e assistência às pessoas traficadas (Alencar, 2007, p.25).

O Protocolo Adicional à Convenção das Nações Unidas contra o Crime Organizado Transnacional relativo à Prevenção, Repressão e Punição do Tráfico de Pessoas, em especial Mulheres e Crianças - Protocolo de Palermo (2000) foi o primeiro documento a tratar sobre tráfico de pessoas, apresentando uma definição para este tipo de crime. Porém este foi o ponto mais controvertido, que gerou debates acalorados e muita divergência.

Alguns autores assinalam que as definições de tráfico de pessoas estão associadas ao controle e à prevenção do crime organizado transnacional e à preocupação com violações das leis de imigração ${ }^{18}$.

As divergências dividiram as opiniões das diversas organizações presentes na Convenção, tanto que em dezembro de 2000, quando abriu para assinaturas, o Protocolo de Palermo recebeu a assinatura de apenas 80 países (Ditmore \& Wijers, 2003, p. 79).

Um dos aspectos principais de conflito foi em relação à prostituição.

\begin{abstract}
Mas, antes da aprovação, havia de se chegar a um consenso interno sobre a questão do tráfico, o que se tornou especialmente difícil, segundo Melissa Ditmore que participava nas negociações, pelo envolvimento da questão da prostituição, pois introduz o elemento moral no debate, ou seja, a identificação do tráfico como problema de exploração sexual relacionada à prostituição leva a expressar posições divergentes sobre o assunto em geral(...) Enquanto a maior parte dos representantes governamentais era de homens, a maioria das participantes por parte das ONGs era feminina, o que teria salientado ainda mais as divergências ideológicas sobre a relação entre o tráfico e a prostituição, não somente entre as delegações de Estado, mas também entre as ONGs feministas de pressão (Ausserer, 2007, p.39).
\end{abstract}

Dois grupos feministas irão competir para influenciar na elaboração do conteúdo final do Protocolo que apesar de convergirem no interesse na

\footnotetext{
${ }^{18}$ Cf. Anderson e O'Conell Davidson, 2004; kempadoo, 2005.
} 
promoção das mulheres, divergem em relação à concepção de prostituição e sobre a relação entre prostituição e tráfico.

O primeiro grupo, Human Rights Caucus, liderado pela organização não governamental Global Alliance Against Traffic in Women - GAATW ${ }^{19}$, composto por organizações de direitos humanos, por ativistas contra 0 tráfico e representantes de trabalhadoras do sexo. Esse grupo defendia uma definição de tráfico que incluísse trabalhos forçados, escravidão e servidão, independente da natureza da atividade realizada ou do sexo da pessoa traficada, excluindo qualquer tipo de atividade sexual realizada de forma voluntária e não coercitiva.

Distingue ainda a prostituição voluntária do tráfico de pessoas, visto que o tráfico ocorre com a presença de coerção, engano, abuso de autoridade ou qualquer outra forma de abuso em relação às condições de recrutamento, bem como de trabalho. Porém, entende que em relação ao tráfico de crianças, a existência ou não de coerção é desnecessária para configurar o delito.

Outro aspecto defendido por este grupo relaciona-se à necessidade de proteção aos direitos humanos das vítimas do tráfico, independente de sua participação como testemunhas em procedimentos judiciais. Além de prever a assistência médica, legal e social à vítima, bem como a possibilidade dela receber a indenização, vistos de trabalho e permanência durante o tempo de duração dos procedimentos judiciais.

Atenta-se ainda, para necessidade de se incluir uma cláusula antidiscriminação para deixar claro que as pessoas traficadas não devem receber um tratamento discriminatório nem pela legislação nem pela atuação dos agentes governamentais (Ditmore \& Wijers, 2003).

O segundo grupo, liderado pela Coalition Against Trafficking in Women CATW, composto por integrantes que advogam a perspectiva abolicionista, que colocam a prostituição como fonte do problema do tráfico de pessoas, defendia que a prostituição em si é uma forma de violação de direitos humanos que deve ser abolida e punida, sem prejudicar as prostitutas, haja vista que são consideradas vítimas e devem ser tratadas como tal ${ }^{20}$.

\footnotetext{
${ }^{19}$ Organizações que faziam parte do Human Rights Caucus quando da aprovação do Protocolo de Palermo: Global Alliance against Traffic in Women (GAATW, Tailândia), International Human Rights Law Group (IHRLG, EUA), Foundation against Trafficking in Women (Países-Baixos), Asian Women's Human Rights Council (AWHRC, Filipinas, Índia), La Strada (Polônia, Ucrânia, República Checa), Fundación Esperanza (Colômbia, Países-Baixos, Espanha), Ban-Ying (Alemanha), Foundation for Women (Tailândia), KOK-NGO Network Against Trafficking in Women (Alemanha), Women's Consortium of Nigéria, Women, Law and Development in África (Nigéria). Cfr. Ditmore; Wijers (2003), p. 80

${ }^{20}$ Cf. Ditmore; Wijers, 2003: p.80; Doezema, 2005: p. 67.
} 
Esse grupo, não distingue a prostituição voluntária da prostituição forçada, visto que para eles toda prostituição seria considerada forçada.

Nas negociações do Protocolo de Palermo este grupo defendia a inclusão do termo prostituição na definição de tráfico, independentemente das condições de trabalho, da existência de consentimento ou de força. Sugeriu, inclusive, que o título do documento se referisse ao tráfico de mulheres e crianças (Ditmore \& Wijers, 2003)

Os debates acerca da definição de tráfico de pessoas no Protocolo se centraram em saber se a mulher poderia ou não escolher trabalhar na indústria do sexo e se o tráfico deveria ser definido pela natureza do trabalho ou pelo uso do engano ou da coação.

Essa questão remete a outro ponto polêmico no debate destas duas organizações dentro da elaboração do Protocolo, que é a questão do consentimento.

A discussão sobre o consentimento sempre é retomada, contudo sem consenso quando se fala da prostituição da mulher adulta, abordando a natureza da própria prostituição, o que Bassiouni (2002) soube resumir muito bem:

\begin{abstract}
Essa questão abrange 0 debate sobre se uma mulher pode consentir na prostituição. Alguns dizem que não, mas os defensores dos direitos humanos afirmam que os trabalhadores do sexo têm direitos como quaisquer outros trabalhadores. Alguns baseiam seus argumentos na irrefutável presunção de nulidade de qualquer concordância com a prática da prostituição e outras formas de trabalho sexual que se fundamentam na natureza lucrativa dessa atividade. Outros apóiam esse ponto de vista porque consideram esse tipo de consentimento para se prostituir como resultado da coação econômica ou abuso da vulnerabilidade econômica da pessoa em questão. Aqueles que se posicionam no lado contrário do debate sustentam que as mulheres podem admitir livremente em se tornarem trabalhadores sexuais e que essa escolha deve ser respeitada. Existe consenso quanto à incapacidade de um menor de idade dar consentimento válido a esse tipo de exploração mas, ainda assim, discute-se qual a idade para o consentimento à luz da diversidade cultural no mundo(p.3).
\end{abstract}

De acordo com o grupo liderado pela Coalition Against Trafficking in Women - CATW, não é possível a existência de consentimento verdadeiro para a prostituição, visto que esta é uma forma de violência sexual. Para este grupo, a aceitação do consentimento como condição para a caracterização do tráfico, levaria os traficantes a usarem este argumento para escaparem da punição. A questão é que, este grupo considera todo tipo de trabalho sexual comercial como tráfico, independentemente dos meios utilizados. 
De acordo com Doezema (2004), esta linha de pensamento, apoiada por diversos governos e pelo Vaticano, se fundamenta na ideia de que o consentimento para realizar trabalhos sexuais carece de sentido. Há o entendimento de que o trabalho sexual é inerentemente uma violação de direitos humanos, de maneira análoga ao estupro, à mutilação genital e ao incesto. As feministas abolicionistas reivindicam a penalização da demanda de sexo comercial e a abolição da prostituição em geral, que, segundo elas, solucionaria também o problema do tráfico.

Enquanto o grupo liderado pela Global Alliance Against Traffic in Women - GAATW, sustenta que as mulheres podem admitir livremente em se tornarem trabalhadores sexuais e que essa escolha deve ser respeitada, distinguindo entre prostituição forçada e prostituição voluntária - que deveria ser reconhecida como trabalho. O consentimento, associado ao uso da força, da coação e do engano, é que caracterizaria o tráfico.

No entanto, na aprovação do Protocolo de Palermo, em relação à questão do consentimento, chegou-se a aceitação de que o consentimento, conseguido através da força, coação ou engano, não seria considerado um consentimento verdadeiro, chamado também de consentimento induzido.

Assim, a partir das negociações em torno do Protocolo de Palermo chegou-se ao seguinte posicionamento: "o consentimento dado pela vítima de tráfico de pessoas tendo em vista qualquer tipo de exploração será considerado irrelevante se tiver sido utilizado qualquer um dos meios referidos na alínea a" (Protocolo de Palermo, 2000, artigo 3ํㅡㄹ alínea b), ou seja, conseguido por meio de coação, engano ou uso da força.

As divergências conceituais em disputa por estes dois grupos dentro do movimento feminista contemporâneo em relação ao tráfico, principalmente de mulheres, está longe de um consenso, pois cada vertente quer impor sua própria perspectiva como concepção "oficial" de tráfico de pessoas. E a estas concepções vão se agregando outros grupos em função de outros interesses, inclusive opostos àqueles objetivados pelo feminismo.

De acordo com Ausserer (2007, p.42),

Ao longo das negociações, os dois grupos aumentaram a pressão para influenciar o protocolo em vários encontros informais com as delegações de Estado. Enquanto, por exemplo, o Vaticano, a Bélgica, a Suécia, a França, a Noruega, a Finlândia, o Marrocos, a Argélia, o Egito, junto com as Filipinas, o Paquistão, a Índia, a China, os Emirados Árabes, a Síria, o México, a Venezuela, a Colômbia e a Argentina lutam para implementar a posição da CATW; os Países Baixos, a Holanda, a Alemanha, a Dinamarca, a Irlanda, a Suíça, a Espanha, a Grã-Bretanha, junto com alguns países da antiga União 
Soviética(como Azerbaijão), a Austrália, a Nova Zelândia, a Tailândia, o Japão e o Canadá defendem a posição das Human Rights Caucus.

Mesmo com todas as divergências e debates envolvendo um conceito para tráfico de pessoas, foi decidido que no artigo $3^{\circ}$, referente às definições, assim disporia:

a) A expressão "tráfico de pessoas" significa o recrutamento, o transporte, a transferência, o alojamento ou o acolhimento de pessoas, recorrendo à ameaça ou uso da força ou a outras formas de coação, ao rapto, à fraude, ao engano, ao abuso de autoridade ou à situação de vulnerabilidade ou à entrega ou aceitação de pagamentos ou benefícios para obter o consentimento de uma pessoa que tenha autoridade sobre outra para fins de exploração. A exploração incluirá, no mínimo, a exploração da prostituição de outrem ou outras formas de exploração sexual, o trabalho ou serviços forçados, escravatura ou práticas similares à escravatura, a servidão ou a remoção de órgãos;

b) O consentimento dado pela vítima de tráfico de pessoas, tendo em vista qualquer tipo de exploração descrito na alínea a) do presente artigo será considerado irrelevante, se tiver sido utilizado qualquer um dos meios referidos na alínea a;

c) O recrutamento, o transporte, a transferência, o alojamento ou o acolhimento de uma criança para fins de exploração serão considerados 'tráfico de pessoas' mesmo que não envolvam nenhum dos meios referidos da alínea a) do presente Artigo;

d) O termo 'criança' significa qualquer pessoa com idade inferior a dezoito anos.

De acordo com esse Protocolo de Palermo, o tráfico é definido como processo que ocorre em várias etapas distintas, conforme alínea a do artigo $3^{\circ}$, envolvendo o recrutamento, transporte, transferência, alojamento ou o acolhimento de pessoa, utilizando qualquer dos meios coercitivos descritos, aplicados de diversas formas, podendo envolver várias pessoas em diferentes etapas, tendo como finalidade a exploração (Anderson \& Davidson, 2004). Com esta redação o documento pretendeu alcançar as diversas ações do tráfico, evocando a ideia da existência de redes criminosas.

O documento enfatiza a necessidade da existência de meios coercitivos para a caracterização de uma situação como tráfico de pessoas. São eles a ameaça, o uso da força ou outras formas de coerção, o rapto, a fraude, o engano, o abuso de autoridade, a situação de vulnerabilidade, a entrega ou aceitação de pagamentos ou benefícios para obter o consentimento de uma pessoa que tenha autoridade sobre outra. 
Na definição do Protocolo, o tráfico ocorre com a finalidade da exploração de alguém em diversos setores do mercado de trabalho. Essa exploração se refere às condições de trabalho às quais as pessoas são submetidas e como se desenvolve a relação trabalhista, muitas vezes se submetendo o trabalhador a horas extenuantes de atividade, desenvolvida de modo forçado, em condições inadequadas, restringindo sua liberdade de locomoção, recebendo baixo ou nenhum pagamento e sem a observância da legislação trabalhista (Sales \& Alencar, 2008).

O conceito de tráfico assumido pelo Protocolo de Palermo abrange diversas finalidades - retirada de órgãos, exploração sexual, trabalho forçado e a escravidão - o que o torna bastante generalizante na compreensão de processos específicos, de diferentes aspectos e dimensões.

No entanto, o documento não especifica o que entende por "outras formas de coerção" ou o "abuso de autoridade ou de uma situação de vulnerabilidade" ou "exploração". Esta ausência de uma maior clareza de "pontos chaves", deve-se às divergências de concepções presentes na sua elaboração.

O uso do termo "abuso de uma situação de vulnerabilidade", aparece comumente associado em discursos oficiais que tratam do tráfico de pessoas, associado às mulheres (evocando numa visão sexista), principalmente, se forem pobres e oriundas de países do Terceiro Mundo, que migram para melhorar as condições de vida e trabalho.

Como destaca Piscitelli (apud Alencar, 2007),

\begin{abstract}
O ponto que se refere ao abuso de poder ou de uma posição de vulnerabilidade adquire particular relevância nas abordagens preocupadas com a visão sobre as mulheres do Terceiro Mundo construída nesse debate, que é considerada imperialista. Nessa visão, a imagem das mulheres das regiões pobres do mundo é construída em contraposição à maneira como são percebidas as mulheres do Primeiro Mundo (Doezema, 2001). Essas últimas são vistas como tendo controle sobre seus rendimentos, corpo e sexualidade, emancipadas e independentes. Ao contrário, as mulheres das regiões pobres são, de maneira axiomática, consideradas pobres, ignorantes, carentes de educação, pessoas que precisam de guia, conselhos e ajuda (Kempadoo, 1998).
\end{abstract}

Essa associação que relaciona as mulheres de regiões mais pobres com a concepção de vulnerabilidade, tende a ser discriminatória e perigosa, pois deixa subentendido que qualquer mulher destes países que venham a atravessar as fronteiras, poderiam ser consideradas vítimas de abuso de poder ou estarem numa posição de vulnerabilidade.

Neste sentido, aumenta a possibilidade dos países, reatualizarem formas de controle ao proporem a proteção de mulheres que migram, principalmente 
aquelas sozinhas e oriundas de países de Terceiro Mundo, através de políticas e de leis restritivas, voltadas para coibir a migração irregular e a inserção de mulheres na indústria do sexo e que acabem penalizando e prejudicando estas mulheres quando em deslocamento.

Em relação à finalidade do tráfico para fins de exploração, o Protocolo também deixa pontos pouco esclarecidos sobre as diversas formas de exploração ${ }^{21}$.

Apesar do Protocolo mencionar os diversos tipos de exploração -a exploração da prostituição de outrem ou outras formas de exploração sexual, o trabalho ou serviços forçados, escravatura ou práticas similares à escravatura, a servidão ou a remoção de órgãos - há uma ênfase na finalidade da exploração sexual, que aparece fora da classificação de trabalho forçado, que não só engloba o trabalho escravo e servidão, como também a exploração sexual.

Provavelmente, isto se deva à pressão de grupos feministas e ao fato de mulheres e crianças serem apontadas, por diversos estudos e pesquisas, como as principais vítimas do tráfico.

Os destaques dados às expressões "exploração da prostituição de outrem" ou "outras formas de exploração sexual" são criticados em face de sua imprecisão, o que não auxilia em nada a compreensão desse tipo de exploração, e principalmente, por se referir a uma atividade específica, a prostituição, quando o intuído era desvincular o tráfico de qualquer atividade laboral, para compreendê-lo como uma conduta na qual se usam meios fraudulentos para explorar alguém. $^{22}$

Assim, com a indefinição deste ponto, deixou-se para que, cada Estado, pudesse interpretá-lo de acordo com seu ordenamento jurídico interno. De acordo com Alencar (2007, p.35), "essa indefinição ocorreu em face da existência de diversos tipos de legislação sobre a prostituição em diferentes países, como é o caso da Alemanha e da Holanda, que regulamentam a prostituição como atividade profissional, e da Suécia, que a proíbe expressamente".

Mas as atividades na indústria do sexo não se referem somente à prostituição, pois envolvem também os serviços de entretenimento sexual, como dançarinas, stripteases, shows de sexo ao vivo, serviços de tele-sexo, entre vários outros (Anderson \& Davidson, 2004).

\footnotetext{
${ }^{21} \mathrm{Na}$ impossibilidade de um acordo sobre certas expressões utilizadas pelo Protocolo, abriu-se a possibilidade a cada país, de dar uma interpretação própria de acordo com suas leis internas.

${ }^{22}$ Cf. Piscitelli apud Alencar, 2007, p. 34; Anderson \& Davidson, 2004.
} 
Para Piscitelli (apud Alencar, 2007), a exploração e o tráfico de pessoas não estão automaticamente vinculados à existência da indústria do sexo, mas são favorecidos pela falta de proteção dos trabalhadores nesse setor. Aqueles que traficam se beneficiam das migrações (internas e internacionais) e dos trabalhos sexuais comerciais.

O fato de a prostituição ser uma atividade extremamente estigmatizada e não vista como trabalho na maioria dos Estados, faz com que os trabalhadores sexuais sejam alvo de preconceitos, que colocam essa atividade entre os espaços mais subalternos e marginalizados dos setores informais. Pouco controlados e regulamentados, o que torna possíveis diversas formas de exploração e violência ${ }^{23}$

Em relação às outras finalidades do tráfico de pessoas, distinguidas pelo Protocolo de Palermo - para "trabalhos ou serviços forçados", "escravidão", "práticas análogas à escravidão" e "servidão" - a Organização Internacional do Trabalho - OIT considera que representam modalidades gerais de violação dos direitos humanos, sendo que cada tipo faz referência a uma forma específica dessa violação envolvendo diferenciações dentro trabalho forçado, e define:

Assim, a "escravidão" é uma forma de trabalho forçado que implica no controle absoluto de uma pessoa por outra, ou, eventualmente, de um coletivo social por outro, e, significa o exercício de todos ou alguns dos poderes decorrentes do direito de propriedade. As "práticas análogas à escravidão" incluem situações nas quais um indivíduo ou coletivo social se vê forçado a trabalhar para outro ou outros. A "servidão" denomina as situações nas quais um indivíduo é levado a realizar um trabalho endividando-se ao mesmo tempo, em função dos custos associados à realização desse trabalho (transporte, alimentação, equipamentos de trabalho e de proteção) (OIT, 2001, p.8).

De acordo com Relatórios Globais sobre Trabalho Forçado de 2001 e 2005 da OIT, o trabalho forçado não pode ser equiparado somente a baixos salários ou más condições de trabalho, mas sim definido como uma grave violação de direitos que se manifesta fundamentalmente pela restrição da liberdade do trabalhador ou trabalhadora. E deve conter dois elementos centrais: ser o trabalho ou serviço imposto sob ameaça de punição e executado involuntariamente.

A ameaça de punição, que determina o trabalho forçado, pode assumir múltiplas e diferentes formas: a ameaça de violência física contra o trabalhador

\footnotetext{
${ }^{23} \mathrm{Cf}$. Alencar, 2007, p.37.
} 
ou sua família; a ameaça de violência sexual; a ameaça de confinamento físico ou de imposição de penas financeiras; a ameaça de denúncia às autoridades e de deportação; a ameaça de demissão, de exclusão de futuros empregos ou da comunidade e da vida social; a ameaça da supressão de direitos ou privilégios; a ameaça de privação de alimentos, abrigo ou outras necessidades; a ameaça de imposição de condições de trabalho ainda piores; e finalmente a ameaça à perda da condição social. ${ }^{24}$

A ausência de consentimento, na caracterização do trabalho forçado, segundo Vasconcelos e Bolzon (2008), pode ser verificada nos casos de nascimento em regime de escravidão ou servidão ou ainda ascendência escrava ou servil; rapto ou sequestro físico; venda de uma pessoa a outra; confinamento físico no local de trabalho; coação psicológica (leia-se ordem de trabalhar acompanhada de ameaça de pena em caso de não cumprimento); endividamento induzido; engano sobre as condições de trabalho; retenção ou não pagamento de salários; retenção de documentos.

Assim o elemento definidor da situação de trabalho forçado é a natureza da relação do trabalhador ou trabalhadora com o "empregador" e não, a natureza da atividade desenvolvida ou mesmo por sua legalidade ou ilegalidade (OIT, 2005, p.5).

No entanto, a questão do consentimento deve também ser problematizada, pois muitas situações de trabalho forçado iniciam-se com o livre engajamento do trabalhador ou trabalhadora, e depois há a perda de liberdade, por meio de coerções legais, físicas ou psicológicas que impedem o rompimento da relação de trabalho (Vasconcelos; Bolzon, 2008).

Cabe ressaltar que este consentimento inicial é considerado irrelevante se obtido por fraude ou engano. E neste caso é considerado tráfico.

De acordo com a OIT, é essencial compreender os principais aspectos de grande parte do trabalho forçado contemporâneo:

Primeiro, é mais comum ser imposto por agentes privados do que diretamente pelo Estado. Segundo, o endividamento induzido é um poderoso meio de coerção, reforçado por ameaças de violências ou de castigos contra trabalhadores vítimas do trabalho forçado ou suas famílias. Terceiro, a precariedade da situação legal de milhões de migrantes, mulheres e homens, torna-os particularmente vulneráveis à coação, tendo em vista a ameaça adicional e sempre presente de denúncia às autoridades. As vítimas podem se ver diante da difícil opção entre aceitar condições de trabalho altamente exploradoras ou correr o risco de deportação para seus países de origem se partirem para a defesa de seus direitos. Quarto, um número cada vez maior de pesquisas, especialmente sobre a situação de vítimas do tráfico para trabalho

${ }^{24}$ Cf. OIT, 2005; Vasconcelos; Bolzon, 2008. 
forçado em países industrializados, tem ajudado a identificar grave lacuna legislativa que dificulta a luta contra formas ocultas e muitas vezes sutis de coação na economia privada (OIT, 2005, p 2).

Os Relatórios Globais sobre Trabalho Forçado de 2001 e 2005 da OIT destacam que o conceito de trabalho forçado engloba a exploração sexual comercial e a prostituição forçada.

A expressão exploração sexual comercial, nos documentos da OIT, refere-se às situações nas quais mulheres ou homens entram, de forma involuntária, na prostituição ou em outras formas de atividade sexual comercial, ou entram na prostituição por vontade própria, mas não podem abandoná-la. A expressão também é utilizada para todos os casos em que crianças e adolescentes exercem atividades sexuais comerciais. No caso da exploração sexual comercial de pessoas adultas também se utiliza a expressão prostituição forçada, no intuito de marcar a diferença com as situações de prostituição voluntária (OIT, 2005).

O mesmo não ocorre com crianças adolescentes, pois há o entendimento que, como pessoas ainda em processo de formação, estes/as não poderiam optar voluntariamente pelo exercício da prostituição. Nesse sentido, utiliza-se sempre a expressão exploração sexual ${ }^{25}$.

No que se refere ao tráfico de pessoas e ao trabalho forçado, apesar de serem práticas distintas, podem acontecer casos de tráfico com a finalidade da exploração por meio da realização de trabalho forçado, mas nem todo trabalho forçado é fruto do tráfico. Para o trabalho forçado seja considerado tráfico precisa ter todos os elementos que caracterizam o tráfico ${ }^{26}$.

O Protocolo de Palermo ao não conceber a exploração sexual como um tipo de trabalho forçado, revela a predominância de questões moralizantes, relativas às mulheres e tendencia a uma perspectiva abolicionista.

Esses fatos põem assim desafios conceituais e reptos à aplicação da lei. Introduz na lei internacional o conceito de exploração - geralmente desdobrado em exploração do trabalho e exploração sexual - sobre o que são escassos os precedentes jurídicos. E impuseram aos Estados signatários, muitos dos quais até então já tinham adotado leis antitráfico, que cobrem apenas a exploração sexual de mulheres e crianças, a adoção ou emenda de suas leis com vista a um

\footnotetext{
${ }^{25}$ Cf. OIT, 2005: p.11.

${ }^{26}$ De acordo com o Protocolo de Palermo, são elementos que caracterizam o tráfico: a) Ato: Recrutamento, transporte, transferência, alojamento ou o acolhimento de pessoas; b) Meio: Ameaça ou uso da força, coerção, abdução, fraude, engano, abuso de poder ou de vulnerabilidade, ou pagamentos ou benefícios em troca do controle da vida da vítima; c) Finalidade: para fins de exploração, que inclui prostituição, exploração sexual, trabalhos forçados, escravidão, remoção de órgãos e práticas semelhantes (UNODC).
} 
conceito mais amplo de tráfico e exploração (...) No momento presente, a tendência global aponta para a criminalização do tráfico como delito grave, prevendo-se na legislação a identificação e ação penal por imposição de trabalho forçado, entre outras coisas. Isso pode ter um impacto positivo na luta contra a exploração coercitiva de trabalhadores migrantes, desde que os Estadosmembros legislem contra o tráfico em sentido mais amplo, primeiro dispensando atenção às dimensões do trabalho forçado, além da exploração sexual, e, segundo, alocando recursos suficientes para medidas de aplicação da lei nesse aspecto (OIT, 2005, p. 7-8).

A inclusão da remoção de órgãos como uma das finalidades do tráfico segundo Ditmore e Wijers (2003), provocou pouco debate, porém inúmeros representantes pleitearam a inclusão da remoção de órgãos na elaboração do Protocolo.

O objetivo desse tipo de tráfico é a remoção de órgãos para compra e venda no "mercado negro". Trata-se de uma prática ilegal em todo o mundo. As legislações dos Estados geralmente se referem à livre disposição dos órgãos após a morte, ou, no caso daqueles que não são vitais, ainda durante a vida. Mas sua comercialização é vedada.

Contudo, essa é uma prática que vem se desenvolvendo em algumas regiões. Geralmente pessoas ricas, que têm problemas de saúde e não encontram doadores de órgão para realizar um transplante nem querem expor seus familiares aos riscos de uma cirurgia, contatam grupos que comercializam órgãos no "mercado negro" para adquirir aqueles que Ihes são necessários (Alencar, 2007, p 42).

Sabe-se que essa comercialização geralmente ocorre em regiões empobrecidas do mundo, onde pessoas com problemas econômicos são convencidas a vender um de seus órgãos ou são até mesmo enganadas para tal (Arruda, 2004). Entretanto, ainda há poucas informações sobre esta modalidade de tráfico. E o Protocolo não explicita o que entende por este crime.

Os pontos divergentes, sobre os quais não se obteve consenso, foram deixados a cargo dos Estados-partes, a interpretação e sua definição, bem como dos dispositivos que objetivam promover a defesa e a proteção daqueles que foram traficados.

De acordo com o Protocolo, os Estados são aconselhados a adotar métodos efetivos para promover a cooperação entre eles, prevenir o tráfico humano por meio de informação e da educação do público, assegurando que as pessoas lesadas recebam assistência e proteção e de prover, quando necessário, o retorno das vítimas aos países de origem.

Contudo, de acordo com Alencar (2007) pela leitura do Protocolo de Palermo, verifica-se que os dispositivos, especialmente os que tratam do 
repatriamento dessas pessoas e do controle dos documentos, foram incisivos e não discricionários.

O Protocolo de Palermo dedica grande parte do seu texto à especificação do fortalecimento de regimes de fronteira e visa à proteção das pessoas traficadas, sobretudo em termos de repatriação.

Ditmore e Wijers (2003)destacam que essa discricionariedade acabou prevalecendo em face dos diferentes interesses dos Estados. Enquanto os Estados desenvolvidos estavam preocupados com os direitos a serem concedidos aos "imigrantes ilegais", os em desenvolvimento, estavam atentos aos custos de suas obrigações em providenciar proteção e assistência às pessoas traficadas. Assim, cada grupo tinha seu próprio interesse em manter a discricionariedade dos dispositivos do documento.

Caroline Ausserer (2007) observa que na maioria dos países há uma ênfase na resposta da justiça criminal para combater o tráfico. Os interesses dos sujeitos em situações de tráfico são subordinados aos interesses do Estado, materializados na repressão ao crime. Entretanto, essa ênfase tende a estar entrelaçada com a relevância concedida pelos governos ao combate à migração não documentada.

As reflexões realizadas até aqui, permite perceber que são muitos os problemas a serem enfrentados na produção de conhecimento sobre o tráfico de mulheres, visto que esta é uma arena permeada pelo entrecruzamento de lógicas, nem sempre consensuadas, produzidas por diferentes sujeitos supranacionais, transnacionais e nacionais ${ }^{27}$ - envolvidos com este tema.

Mesmo com tantas imprecisões, contradições e divergências, há consenso de que o Protocolo de Palermo trouxe avanços em relação às convenções anteriores sobre a matéria do tráfico de pessoas.

\footnotetext{
${ }^{27}$ De acordo com Rapport e Overing (2000), podem ser consideradas supranacionais e transnacionais aquelas lógicas percebidas por se atribuir o direito de determinar e monitorar os comportamentos em escala global. Para estes autores lógicas supranacionais são as que orientam organismos ou entidades como as Nações Unidas ou a União Europeia, e transnacionais, as que alimentam Organizações não-governamentais como Amnesty International ou a Human Rights Watch e, no que se refere à prostituição, os grandes grupos e coalizões informados por correntes feministas divergentes.
} 


\section{3 \\ O tráfico de pessoas na legislação brasileira}

O Brasil, desde o início do século $X X$, participou de importantes encontros internacionais, ratificando todos os documentos internacionais referentes ao tráfico ${ }^{28}$.

Durante todo esse período de debates sobre o tráfico de mulheres e, atualmente, sobre o tráfico de pessoas, além de ratificar os documentos internacionais que versam sobre essa temática, o Brasil veio adequando sua legislação interna ao que estava sendo decidido em nível internacional, conforme os documentos que ratificou.

O Brasil ratificou a Convenção de Palermo e seus protocolos adicionais ${ }^{29}$, incorporando alterações ao Código Penal em 2005 e posteriormente em 2009.

O Código Penal brasileiro, de 1940, em seu art. 231, previa apenas a criminalização do tráfico internacional de mulheres para prostituição.

Em 2005, este artigo foi reformulado, passando a ser criminalizado o "tráfico internacional de pessoas" e foi incluído na legislação referida o tipo penal "tráfico interno de pessoas" (art. 231-A). Ambos os tipos penais referiam-se apenas ao tráfico para exercício da prostituição.

Em 2009, nova alteração legislativa modificou os tipos penais para "tráfico

internacional de pessoa para fim de exploração sexual" (art. 231) e "tráfico interno de pessoa para fim de exploração sexual" (art. 231-A). Em ambos, o tráfico refere-se ao exercício da prostituição ou outra forma de exploração sexual, sem esclarecer contudo o que entende por estes conceitos.

\footnotetext{
${ }^{28}$ Documentos internacionais ratificados pelo Brasil: Protocolo de Emenda e a Convenção Internacional para a Repressão do Tráfico de Mulheres e de Crianças de 1921 (Decreto $n^{\circ} 23.812$ de 1930); Convenção para a Repressão do Tráfico de Mulheres Maiores, de 11 de outubro de 1933 (Decreto n० 37.176 de 1955); Convenção para a Repressão do Tráfico de Pessoas e do Lenocínio e Protocolo Final (Decreto n 46.981 de 1959); e o mais recente Protocolo Adicional à Convenção das Nações Unidas contra o Crime Organizado Transnacional Relativo à Prevenção, Repressão e Punição do Tráfico de Pessoas, em Especial Mulheres e Crianças, conhecido com Protocolo de Palermo (Decreto n 5.017 de 2004).Fonte: Ministério das Relações Exteriores. Atos multilaterais assinados pelo Brasil no âmbito do Direito Penal. Disponível em: <http://www2.mre.gov.br/daí/dpenal.htm>. Acesso em: 18 jan. 2006.

${ }^{29} \mathrm{O}$ Decreto $\mathrm{N}^{\circ} 5.015$, de 12 de março de 2004, promulgou a Convenção das Nações Unidas contra o Crime Organizado Transnacional. O Decreto $N^{\circ}$ 5.016, de 12 de março de 2004, promulgou o Protocolo Adicional à Convenção das Nações Unidas contra o Crime Organizado Transnacional, relativo ao Combate ao Tráfico de Migrantes por Via Terrestre, Marítima e Aérea. O Decreto $\mathrm{N}^{\circ}$ 5.017, de 12 de março de 2004, promulgou o Protocolo Adicional à Convenção das Nações Unidas contra o Crime Organizado Transnacional Relativo à Prevenção, Repressão e Punição do Tráfico de Pessoas, em Especial Mulheres e Crianças - Protocolo de Palermo em março de 2004.
} 
As alterações feitas em 2005 e 2009 não modificaram substancialmente a tipificação de 1940, pois as tipificações mais recentes seguem fazendo referência apenas à prostituição ou outra forma de exploração sexual. 


\section{Quadro 1- Alterações no Código Penal Brasileiro em relação à tipificação do tráfico de pessoas}

\begin{tabular}{|c|c|c|c|}
\hline $\begin{array}{c}\text { Artigo } \\
231\end{array}$ & $\begin{array}{l}\text { Tráfico de } \\
\text { mulheres } \\
\text { Código } 1940\end{array}$ & $\begin{array}{l}\text { Tráfico Internacional de } \\
\text { Pessoas } \\
\text { Redação dada pela Lei no } \\
\text { 11.106, de } 2005\end{array}$ & $\begin{array}{l}\text { Tráfico internacional de } \\
\text { pessoas } \\
\text { para fim de exploração sexual } \\
\text { Redação dada pela Lei no } \\
12.015 \text {, de } 2009\end{array}$ \\
\hline & $\begin{array}{l}\text { Art. 231. Promover } \\
\text { ou facilitar a entrada, } \\
\text { no território nacional, } \\
\text { de mulher que nele } \\
\text { venha exercer a } \\
\text { prostituição, ou a } \\
\text { saída de mulher que } \\
\text { vá exercê-la no } \\
\text { estrangeiro. }\end{array}$ & $\begin{array}{l}\text { Art. 231. Promover, intermediar } \\
\text { ou facilitar a entrada, no território } \\
\text { nacional, de pessoa que venha } \\
\text { exercer a prostituição ou a saída } \\
\text { de pessoa para exercê-la no } \\
\text { estrangeiro. }\end{array}$ & $\begin{array}{l}\text { Art. 231. Promover ou facilitar a } \\
\text { entrada, no território nacional, de } \\
\text { alguém que nele venha a exercer a } \\
\text { prostituição ou outra forma de } \\
\text { exploração sexual, ou a saída de } \\
\text { alguém que vá exercê-la no } \\
\text { estrangeiro. }\end{array}$ \\
\hline & $\begin{array}{l}\text { Pena - reclusão, de } \\
\text { três oito anos. }\end{array}$ & $\begin{array}{l}\text { Pena - reclusão, de } 3 \text { (três) a } 8 \\
\text { (oito) anos e multa. }\end{array}$ & $\begin{array}{l}\text { Pena - reclusão, de } 3 \text { (três) a } 8 \\
\text { (oito) anos. }\end{array}$ \\
\hline & $\begin{array}{l}\S 1^{\circ}-\text { Se ocorre } \\
\text { qualquer das } \\
\text { hipóteses do } \S 1^{\circ} \text { do } \\
\text { art. } 227^{30} \text { : } \\
\text { Pena - reclusão, de } \\
\text { quatro a dez anos. }\end{array}$ & $\begin{array}{l}\S 1^{0} \text { - Se ocorre qualquer das } \\
\text { hipóteses do } \S 1^{\circ} \text { do art. 227: } \\
\text { Pena - reclusão, de } 4 \text { (quatro) a } \\
10 \text { (dez) anos e multa }\end{array}$ & $\begin{array}{l}\S 1^{\circ} \text { Incorre na mesma pena aquele } \\
\text { que agenciar, aliciar ou comprar a } \\
\text { pessoa traficada, assim como, } \\
\text { tendo conhecimento dessa } \\
\text { condição, transportá-la, transferi-la } \\
\text { ou alojá-la. }\end{array}$ \\
\hline & $\begin{array}{l}\S 20 \text { - Se há emprego } \\
\text { de violência, grave } \\
\text { ameaça ou fraude, a } \\
\text { pena é de reclusão, } \\
\text { de } 5 \text { (cinco) a } 12 \\
\text { (doze) anos, além da } \\
\text { pena correspondente } \\
\text { à violência } \\
\text { § 3o - Se o crime é } \\
\text { cometido com o fim } \\
\text { de lucro, aplica-se } \\
\text { também multa. }\end{array}$ & $\begin{array}{l}\S 2^{\circ} \text { Se há emprego de violência, } \\
\text { grave ameaça ou fraude, a pena } \\
\text { é de reclusão, de } 5 \text { (cinco) a } 12 \\
\text { (doze) anos, e multa, além da } \\
\text { pena correspondente à violência. }\end{array}$ & $\begin{array}{l}\S 20 \text { A pena é aumentada da } \\
\text { metade se: } \\
\text { I - a vítima é menor de } 18 \text { (dezoito) } \\
\text { anos; } \\
\text { II - a vítima, por enfermidade ou } \\
\text { deficiência mental, não tem o } \\
\text { necessário discernimento para a } \\
\text { prática do ato; } \\
\text { III - se o agente é ascendente, } \\
\text { padrasto, madrasta, irmão, } \\
\text { enteado, cônjuge, companheiro, } \\
\text { tutor ou curador, preceptor ou } \\
\text { empregador da vítima, ou se } \\
\text { assumiu, por lei ou outra forma, } \\
\text { obrigação de cuidado, proteção ou } \\
\text { vigilância; ou } \\
\text { IV - há emprego de violência, grave } \\
\text { ameaça ou fraude. }\end{array}$ \\
\hline & & & $\begin{array}{l}\text { § 3 Se o crime é cometido com o } \\
\text { fim de obter vantagem econômica, } \\
\text { aplica-se também multa. }\end{array}$ \\
\hline
\end{tabular}

\footnotetext{
${ }^{30}$ Art. 227 - Induzir alguém a satisfazer a lascívia de outrem. Pena - reclusão, de um a três anos. $\S$ 10 Se a vítima é maior de 14 (catorze) e menor de 18 (dezoito) anos, ou se o agente é seu ascendente, descendente, cônjuge ou companheiro, irmão, tutor ou curador ou pessoa a quem esteja confiada para fins de educação, de tratamento ou de guarda: (Redação dada pela Lei no 11.106, de 2005) Pena - reclusão, de dois a cinco anos.
} 
(Continuação)

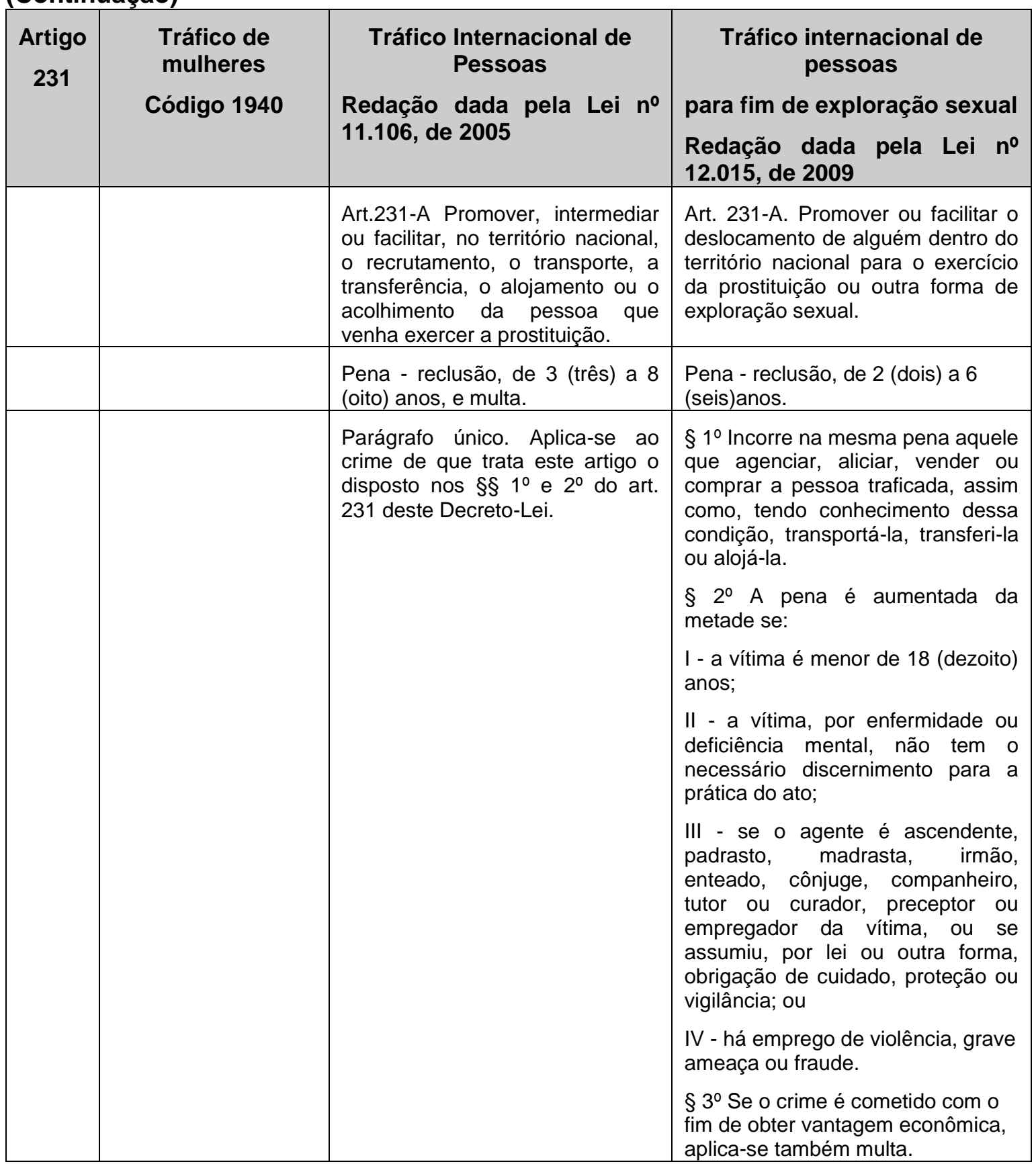


Ao analisar comparativamente o conceito de tráfico de pessoas constante no Protocolo de Palermo e a descrição dos tipos tráfico internacional e interno de pessoas no Código Penal brasileiro, verifica-se que há diferenças consideráveis entre a definição brasileira de tráfico e o texto do Protocolo.

No Protocolo, o crime é definido concedendo ênfase à coerção ou abuso de situação de vulnerabilidade em alguma fase do processo de deslocamento realizado para ser explorado em qualquer setor de atividade. Já no Código Penal, a definição não se baseia na articulação entre coerção e exploração, mas na intermediação ou facilitação de deslocamentos que tem como fim exclusivamente exercer a prostituição (Piscitelli, 2008, p.41-42).

O documento internacional inovou por ampliar o conceito desse delito, porém a lei penal brasileira continuou vinculando $o$ tráfico de pessoas à finalidade exclusiva da prostituição, excluindo desta tipificação a realidade do tráfico interno e internacional para trabalho escravo (tipificado no art.149 CPB), persistente ainda dentro do país, e, de outras modalidades de tráfico previstas no Protocolo, como aliciamento para fins de emigração (tipificado no art. 206 CPB). Ademais, ainda não existe, no Código Penal, a tipificação de tráfico internacional de órgãos.

No Brasil a prostituição autônoma não é crime, tanto que a prostituição consta na Classificação Brasileira de Ocupações do Ministério de Trabalho e Emprego - MTE como item 5198: profissionais de Sexo (MTE, 2008).

Porém a exploração da prostituição é crime previsto no art. 230 do CP.

Ocorre que a redação atual dos artigos 231 e 231-A, criminaliza quem promover ou facilitar a entrada e saída de pessoa que venha a exercer a prostituição, independente se prostituição voluntária ou forçada. Nestes termos, a redação brasileira aparece afinada com a perspectiva feminista abolicionista, que concebe toda e qualquer forma de prostituição como tráfico, e por isso não pode receber ajuda de ninguém para a sua efetivação.

A utilização do termo "para fim de exploração sexual", de forma generalizada no título no artigo 231, já enquadra a prostituição, mesmo que voluntária, como exploração sexual.

Em outras palavras: qualquer pessoa que acolher outra que venha exercer a prostituição, mesmo que autônoma, no exterior ou mesmo no Brasil, em seu hotel ou casa, ou ainda, ajude a sair do país, quer por empréstimo de valor ou por contato que tenha no exterior, mesmo que seja parente ou amigo, será considerada criminosa por promover ou facilitar o tráfico de pessoas para fim de exploração sexual. 
Assim, ignora-se que brasileiros e brasileiras que migram para se inserirem na indústria do sexo, acionam, como outros migrantes, redes de parentes, amigos, vizinhos e conhecidos, como bem analisa Piscitelli (2006),

As discrepâncias, entre o Protocolo e o Código, têm consequências. As brasileiras que migram para inserir-se na indústria do sexo, como outros migrantes, acionam redes (e não me refiro me refiro necessariamente a grupos criminosos organizados, mas a todo tipo de redes incluindo parentes, amigos, vizinhos, conhecidos) para sair do país e se inserir-se em outro, no local de origem e/ou de recepção. Através destas redes eles/as obtêm informações e ajuda para partir e para chegar, para obter abrigo e integrar-se em algum nicho do mercado de trabalho. Essas "ajudas", lidas como facilitação podem, de acordo com o Código Penal ser consideradas tráfico (p.5) No marco desta ambiguidade cabe perguntar-se sobre as lógicas que orientam as ações policias bilaterais, envolvendo o Brasil e países europeus, noticiadas pela mídia como operações que resgatam mulheres brasileiras em situação de tráfico. Tratar-se-ia de lógicas orientadas por ideias vinculadas ao Protocolo de Palermo, no sentido de libertar vítimas encarceradas ou em situação de escravidão e/ou exploração ou se trata de uma lógica que segue a ideia do Código Penal, isto é, procurar pessoas que viajam para prostituir-se mediante algum tipo de facilitação, de ajuda? Essas perguntas podem ter respostas diferentes, dependendo dos discursos e ações considerados, no Brasil e no exterior (p.7-8).

Apesar de "não" criminalizar diretamente a prostituição, dificultam e reprimem a sua prática, o que faz o Brasil se aproximar de uma visão abolicionista da prostituição.

Em relação ao tráfico interno, observa-se que esta referência não existia na redação do Código Penal de 1940. O referido código caracterizava como tráfico de mulheres somente a fase do transporte, ou seja, de entrada ou saída do território brasileiro para fins de prostituição. Somente com a alteração de 2005 é acrescido o artigo 231-A que permanece também na atual redação.

A tipificação do tráfico interno, provavelmente deveu-se a dois aspectos: o primeiro foi os resultados da PESTRAF- Pesquisa sobre Tráfico de Crianças e Adolescentes para fins de exploração sexual comercial no Brasil (2002) ${ }^{31}$, que apresentou rotas de exploração sexual em diversos Estados brasileiros tendo grande repercussão nacional e internacional e outro, pelas crescentes denúncias de exploração sexual de crianças e adolescentes dentro do território nacional, provocando em 2004, a criação de uma CPMI - Comissão Parlamentar Mista de Inquérito para apuração deste crime.

\footnotetext{
${ }^{31} \mathrm{~A}$ PESTRAF, primeira pesquisa de abrangência nacional sobre o tema, foi coordenada internacionalmente pelo Instituto Internacional de Direitos Humanos da Faculdade de Direito da Universidade De Paul de Chicago, pelo Programa de Direitos Humanos da OEA, pela Comissão Interamericana de Mulheres e o Instituto Interamericano del Niño e, nacionalmente pelo CECRIA Centro de Referência, Estudos e Ações sobre Crianças e Adolescentes, sendo concluída e publicada em 2002. Cf. Leal, 2002.
} 
De acordo com o relatório da CPMI (2004):

O crescimento do mercado do sexo e sua diversificação (da prostituição à pornografia na internet, passando por vídeos, fotos, shows e outras formas de que se reveste o sexo como espetáculo e entretenimento) incluíram a criança e o adolescente como um produto especial para o qual há demanda crescente. Esta condição está registrada de forma objetiva na valorização diferente que é conferida às crianças e adolescentes em termos do preço cobrado pelos serviços sexuais. O mercado do sexo é "um ramo de negócios articulado com outros negócios, tanto legais (hotéis, agências de turismo, agências de modelo), como ilegais (falsificação de documentos, tráfico)". Vários tipos de atividade comercial lícita obtêm ganhos financeiros, diretos ou indiretos: bares, boates, hotéis e motéis, taxistas, garçons, postos de gasolina, agências de modelo e de viagem, tráfico de drogas (p.36).

Cabe ressaltar que tráfico interno de pessoas, aplica-se também para mulheres e homens adultos.

Em 2006, criou-se a Política Nacional de Enfrentamento ao Tráfico de Pessoas, por meio do Decreto $n^{\circ} 5.948 / 2006$, que adotou os termos do Protocolo de Palermo, não se atendo exclusivamente ao tráfico para fim de exploração sexual prevista no Código Penal.

A Política Nacional de Enfrentamento ao Tráfico que estabelece princípios, diretrizes e ações de prevenção e repressão ao tráfico de pessoas e de atendimento às vítimas.

Art. $2^{\circ}$ Para os efeitos desta Política adota-se a expressão "tráfico de pessoas" conforme o Protocolo Adicional à Convenção das Nações Unidas contra o Crime Organizado Transnacional Relativo à Prevenção, Repressão e Punição do Tráfico de Pessoas, em especial Mulheres e Crianças, que a define como o recrutamento, o transporte, a transferência, o alojamento ou o acolhimento de pessoas, recorrendo à ameaça ou uso da força ou a outras formas de coação, ao rapto, à fraude, ao engano, ao abuso de autoridade ou à situação de vulnerabilidade ou à entrega ou aceitação de pagamentos ou benefícios para obter o consentimento de uma pessoa que tenha autoridade sobre outra para fins de exploração. A exploração incluirá, no mínimo, a exploração da prostituição de outrem ou outras formas de exploração sexual, o trabalho ou serviços forçados, escravatura ou práticas similares à escravatura, a servidão ou a remoção de órgãos.

$\S 1^{\circ} \mathrm{O}$ termo "crianças" descrito no caput deve ser entendido como "criança e adolescente", de acordo com a Lei no 8.069, de 13 de julho de 1990, Estatuto da Criança e do Adolescente.

$\S 2^{\circ} \mathrm{O}$ termo "rapto" descrito no caput deste artigo deve ser entendido como a conduta definida no art. 148 do Decreto-Lei no 2.848, de 7 de dezembro de 1940, Código Penal Brasileiro, referente ao sequestro e cárcere privado.

$\S 3^{\circ} \mathrm{A}$ expressão "escravatura ou práticas similares à escravatura" deve ser entendida como: 
I - a conduta definida no art. 149 do Decreto-Lei no 2.848, de 1940, referente à redução à condição análoga a de escravo; e

II - a prática definida no art. 1ำ da Convenção Suplementar sobre a Abolição da Escravatura, do Tráfico de Escravos e das Instituições e Práticas Análogas à Escravatura, como sendo o casamento servil.

§ 4ํㅗ A intermediação, promoção ou facilitação do recrutamento, do transporte, da transferência, do alojamento ou do acolhimento de pessoas para fins de exploração também configura tráfico de pessoas.

§ 5 0 tráfico interno de pessoas é aquele realizado dentro de um mesmo Estado-membro da Federação, ou de um Estado-membro para outro, dentro do território nacional.

$\S 6^{0} \mathrm{O}$ tráfico internacional de pessoas é aquele realizado entre Estados distintos.

$\S 7^{0} \mathrm{O}$ consentimento dado pela vítima é irrelevante para a configuração do tráfico de pessoas.

Em janeiro de 2008, foi promulgado o Plano Nacional de Enfrentamento ao Tráfico de Pessoas (PNETP), via Decreto oㅜ 6.347/2008, com vistas a concretizar os princípios, diretrizes e ações estabelecidos na Política Nacional, mediante articulação de diversos órgãos do Poder Público.

A partir de então, o governo brasileiro vem implantando nos estados, na operacionalização desta política, diversos Núcleos de Enfrentamento ao Tráfico de Pessoas - NETP, bem como Postos Avançados nos municípios ${ }^{32}$, atendendo a disposições da Portaria SNJ nํ 31, de 20 de agosto de $2009^{33}$.

Entretanto, os desafios parecem muitos quando se verifica concretamente a proposta dos NETP, na articulação de lógicas diferentes, que envolve as concepções do Protocolo e do Código Penal.

Em entrevista com a Coordenadora do NETP do Rio de Janeiro, Nina Quiroga, em julho de 2011, fala do papel do Núcleo como órgão articulador e a realidade da atuação em rede:

\footnotetext{
${ }^{32}$ Os Postos Avançados têm por principal função prestar serviço de recepção a brasileiros não admitidos ou deportados nos pontos em aeroportos. Estes postos devem receber denominações que não os vinculem explicitamente ao enfrentamento ao tráfico de pessoas, a fim de favorecer o acolhimento das vítimas e evitar a estigmatização.

${ }^{33}$ Segundo a Portaria SNJ no 31, os Núcleos de Enfrentamento ao Tráfico de Pessoas têm por principal função articular e planejar as ações para o enfrentamento ao tráfico de pessoas no âmbito estadual e serão implementados em parceria entre o Governo Federal, por meio da Secretaria Nacional de Justiça, e os governos estaduais. Os Núcleos de Enfrentamento ao Tráfico de Pessoas - NETP - têm o objetivo de atender aos três eixos estabelecidos na Política Nacional de Enfrentamento ao Tráfico de Pessoas. Atualmente, há Núcleos nos Estados de Goiás, Pará, Pernambuco, Rio de Janeiro, São Paulo e Acre e perspectiva de novos Núcleos nos Estados da Bahia e Ceará, sendo que neste último já existe o Escritório de Enfrentamento e Prevenção ao Tráfico de Seres Humanos e Assistência à Vítima, que passará a funcionar como NETP.
} 
O Núcleo de enfrentamento ao tráfico de pessoas do RJ, começou a atuar em 2008, a partir de um convênio com o Ministério da Justiça, dezembro de 2008, mais especificamente. Celebrou este convênio com a duração de 2 anos a ser renovado, em 2010 este convênio terminou, eles pediram uma prorrogação e foi renovado até junho 2011 e agora estamos no processo de pedir a $2^{2}$ renovação. O Núcleo e atua na articulação dos serviços que já existem, dos programas e das redes que porventura diretamente lidem com a questão do tráfico de pessoas. Mas a função do Núcleo é fomentar, articular, capacitar na atuação nestas redes. (...) Muitas vezes estes serviços e estas redes não sabem que lidam com o tráfico de pessoas, até porque historicamente já se tinha algumas políticas ligadas à exploração sexual ou ao trabalho escravo, sem que estas atuações sejam enquadradas no enfrentamento ao tráfico de pessoas e pelo fato da política e do plano serem mais recentes. Mas isto não quer dizer que estas redes não existissem e que não estivessem atacando o problema com as suas definições. O fato da gente criar uma definição não pode eliminar a história de um trabalho com estes problemas que existiam antes. Então existe uma rede que atua no enfrentamento a estas finalidades do tráfico de pessoas. (Nina Quiroga - NETP/RJ).

Um dos desafios é a própria articulação da rede, não governamental e governamental, pois apesar de já existir esta rede para o enfrentamento da exploração sexual de crianças e adolescentes e para o combate ao trabalho escravo, esta ainda não tem uma identidade de rede de combate ao tráfico, visto que a Política e o Plano de enfrentamento ao tráfico são recentes. Este é um aspecto que implica na aparente escassez de casos caracterizados como tráfico de pessoas, o que não significa que eles não existam, mas não são identificados como tal.

Em entrevista com Marcele Marques de Moraes, em julho de 2011, Coordenadora do Consórcio Trama ${ }^{34}$, que é um grupo de quatro instituições da sociedade civil que atua no enfrentamento ao tráfico de pessoas no Estado do Rio de Janeiro, com articulações em nível nacional e internacional, ela também identifica dificuldades na rede de atendimento nos casos de tráfico:

Eu acredito que não chega [os casos de tráfico] por que esta rede ainda não sabe identificar casos de tráfico, então eles acabam vinculando a outras violações de direitos humanos e isso está ficando muito claro para a gente, pois estamos desenvolvendo um curso no Estado do Rio de Janeiro de qualificação da rede para o enfrentamento ao tráfico de mulheres e, é um curso de 24 horas com duração de 3 dias. E temos identificado isso e até os agentes dessa rede tem identificado que, atenderam casos de tráfico para outros fins, não só para fins de exploração sexual, mas foi identificado como outra violação de direitos humanos, outros crimes e não tráfico. Inicialmente nós pensamos em trabalhar com essa rede de atendimento à mulher, mas ao desenvolver o curso nós

\footnotetext{
${ }^{34}$ O Projeto Trama é um consórcio de quatro instituições: CRIOLA - que é uma organização de mulheres negras; IBISS - Instituto de Inovações em Saúde Social; Organização de Direitos Humanos Projeto Legal e Universidade UNIGRANRIO. Criado em 2004 e participa da rede de articulação nacional e internacional, através da Rede LAC - Rede Latino Americana de Enfrentamento ao Tráfico de Mulheres e da GAATW Brasil e Internacional, denominada Aliança Global de Enfrentamento ao Tráfico de Mulheres.
} 
identificamos que nem todos os municípios e nem todas as regiões contam com uma rede especializada no atendimento da mulher. Então hoje nós trabalhamos com DEAMs, delegacias legais, hospitais, Centro de Referência da Mulher, CIAMs. (Marcele - Consórcio Trama).

Outro aspecto, apontado pela Coordenadora do NETP-RJ é a necessidade de compreender e efetivar uma concepção mais ampla sobre o tráfico, visto que são expressivos os casos envolvendo trabalho escravo, tanto no espaço rural como no urbano.

\begin{abstract}
Hoje nós estamos num trabalho articulado entre a Política de Enfrentamento ao Trabalho Escravo, por meio da Comissão de Erradicação do Trabalho Escravo e o trabalho do Núcleo de Enfrentamento ao Tráfico de Pessoas. A Comissão de Trabalho Escravo ela é independente e não está inserida na Política e nem no Plano de Enfrentamento ao Tráfico de Pessoas, inclusive segue uma agenda muito mais ligada ao Ministério do Trabalho e Emprego, tendo uma agenda própria. Este esforço de alinhar e de criar agendas em comum é um esforço muito desta gestão e desse entendimento que a gente tem hoje, de que, a finalidade do tráfico para trabalho escravo, ela hoje é bem mais expressiva, inclusive do que as situações de tráfico com a finalidade de exploração sexual. (...) começou com um apelo muito forte para a exploração sexual e para a mulher especificamente, voltando-se para políticas de atenção à mulher, mas eu acho que aos poucos, eu sinto que há uma preocupação dessa coordenação nacional de observar melhor essas modalidades, inclusive sobre o que gera um foco de tensão muito grande no campo? Relações comerciais? Sociais? Fundiárias? Há uma preocupação em dar uma atenção a questão do trabalho escravo no campo e nos centros urbanos, com as grandes mobilidades nacionais e regionais que a gente está vivendo. Estas mudanças naturalmente tem forçado a uma certa reorientação no Brasil, agora cabe aos núcleos e aos poderes regionais, locais, estaduais e municipais a forçarem um entendimento local desta realidade. (Entrevista Nina Quiroga, coordenadora do NETP -RJ, em julho de 2011).
\end{abstract}

No entanto, a concepção do Código Penal acaba trazendo equívocos que implicam na penalização de quem ajuda no deslocamento da trabalhadora sexual, como é ressaltado pela coordenação do Consórcio Trama.

O Trama sempre trabalhou com a identificação do Protocolo de Palermo que vai dando diversas características dentre o cárcere privado, o engano, o deslocamento. Hoje, o Trama desenvolve suas ações com base no Protocolo de Palermo e não na Legislação brasileira. Apesar de alguns avanços nesta legislação, a gente vê a dificuldade de entender o tráfico com base na legislação brasileira que se limita à exploração sexual de mulheres. Então hoje para a legislação brasileira, o tráfico é para exploração sexual de mulheres e cai em vários erros, quando diz, por exemplo, que uma mãe que empresta dinheiro para uma filha migrar e ela sabendo que para uma questão de prostituição, isso vai qualificar esta mulher como traficante, aliciadora, porque ela facilitou o deslocamento de uma outra pessoa para fins de prostituição. A legislação brasileira está completamente equivocada no que diz respeito ao trafico de pessoas. (Marcele Marques de Moraes - Consórcio Trama). 
Além disso, as ações do Estado brasileiro são voltadas mais ao combate à exploração sexual e à prostituição do que para outras finalidades do tráfico:

As ações que o Estado vem desenvolvendo e a gente vê muito isso na linha da promoção, das grandes campanhas que é uma ação anti-prostituição, não é uma ação anti- tráfico, até porque eles não se preocupam com outros fins de tráfico. O fim de trabalho escravo não é falado, o tráfico de órgãos também não é falado. Enfim a única coisa que é citada nas linhas de atuação do Estado é para fins de exploração sexual e acaba as grandes campanhas tendo um rótulo, sempre uma mulher. A gente sempre identifica a mulher e para fins de exploração sexual. $A$ meu ver hoje, as ações do Estado brasileiro nas campanhas anti-tráfico são na verdade uma ação anti-prostituição. (Marcele Marques - Consórcio Trama).

A consequência disto é a dificuldade de articulação que leva à imobilidade, citando em específico o caso do Rio de Janeiro:

O Rio de Janeiro a nível nacional é o Estado mais atrasado em relação a política anti-tráfico. O I Plano de Enfrentamento ao trafico diz da constituição de um Posto avançado no Rio de Janeiro e de um Comitê, esse não acontece, a gente vê que começa, mas, há uma desmotivação e não acontece. O Comitê no estado do $R J$ teve várias inaugurações. O Ministério da Justiça é o que mais vem realizando ações para que o plano aconteça, e está vindo aio II Plano. São, primeiro, ações de identificação desses casos no Rio de Janeiro, entendendo que o Rio de Janeiro já foi identificado como rota de tráfico. No sentido de investigação e apoio assistencial e de discussão política. Este plano é bem desmembrado e tem várias ações. Não só de identificar, mas efetivamente promover. (Marcele Marques - Consórcio Trama).

Vê-se que a presença das duas definições nos debates, campanhas e ações de enfrentamento ao tráfico no Brasil, ora orientadas pelo Código Penal, ora pelo Protocolo de Palermo, no qual se baseia a Política Nacional de Enfrentamento ao Tráfico de Pessoas, pode trazer entraves, conflitos e equívocos na produção de conhecimento sobre o tráfico de pessoas na realidade brasileira.

Além disso, pode trazer também, dificuldades de articulação de diversos setores do poder público entre si e deste com a sociedade civil organizada (ainda mais se houver um conflito de concepções), e, inviabilizar assim, o avanço de propostas e de ações que venham a favorecer a garantia dos direitos de pessoas, que ao decidirem migrar, encontrem em seus destinos, situações que irão Ihes expor à exploração em diversos ramos de atividade, pelo engano, ameaça ou pela coerção. 


\section{3 \\ Gênero, Feminismos e Tráfico}

A escolha da categoria gênero neste estudo não se deve somente porque se falará de mulheres, mas pela sua importância na análise da dominação masculina e da construção de relações desiguais entre homens e mulheres.

Nesse capítulo recuperar-se-á os primeiros debates sobre o tráfico de mulheres, que eclodiu no século XIX, quando das histórias de tráfico de escravas brancas, articulando tais ideias à tese do determinismo biológico e ao pensamento do movimento feminista emergente na época. Para posteriormente compreender como, na contemporaneidade, as teorias e movimentos feministas problematizarão o debate sobre o tráfico de mulheres a partir do enfoque de gênero.

\section{1 \\ O tráfico de escravas brancas}

As primeiras preocupações sobre o tráfico de mulheres surgem no século XIX, com o tráfico de escravas brancas. É nesta época que o predomínio do determinismo biológico, reforçará a imagem da mulher, branca, ingênua e presa fácil do tráfico. E o surgimento do movimento feminista, iniciará uma cruzada no combata à violência contra as mulheres, considerando a prostituição e o tráfico o lado mais perverso da exploração sexual feminina.

Embora as sociedades patriarcais tenham dividido homens e mulheres estabelecendo mitos e funções sociais e particulares para os diferentes sexos, é na modernidade, que as sociedades burguesas redimensionarão as desigualdades construídas, pela qual o corpo feminino, descrito a partir da ênfase nos órgãos reprodutivos, no 'cérebro menor' e na 'fragilidade dos nervos', foi utilizado para definir o lugar 'naturalmente' inferior das mulheres na sociedade, justificando a sua permanência no espaço privado (Laquer, 1994 Apud Arán, 2003). 
Tais diferenças se construíram a partir de argumentos biológicos, mediante a afirmação da superioridade masculina em relação à inferioridade feminina.

Assim essa representação social do ser homem ou mulher, baseava-se na noção de fixidez que sugere uma representação atemporal e binária de gênero, colocava de uma forma incontestável o significado do homem e da mulher.

As dicotomias binárias não se referiam apenas às diferenças entre homens e mulheres, mas também à natureza/cultura; corpo/mente; branco/negro; heterossexualidade/homossexualidade entre outras, que fundamentaram o pensamento nas sociedades modernas levando à elaboração de teorias que reafirmavam a identidade como uma essência, que independente do contexto ou do tempo, estaria submetida às mesmas e constantes leis.

Com base nestes argumentos, o pensamento liberal, redefiniu o espaço público e privado, delimitando as esferas de atuação de mulheres e homens, cabendo ao homem o espaço público (produção) e à mulher o espaço privado (reprodução). Foi na sociedade capitalista, que a divisão sexual do trabalho se reorganizou e se intensificou, principalmente após a Revolução Industrial, tendo a separação entre o lugar do trabalho e o de morar. Isto refletia a separação entre a produção social e a reprodução dos seres humanos sendo respectivamente, como espaços específicos de homens e mulheres (Guimarães, 2005).

\begin{abstract}
Não podemos perder de vista que um dos fatores mais importantes nascidos do sistema da Revolução Industrial foi o domínio do trabalho-mercadoria, que se materializou na fábrica, ao contrário do trabalho utilidade, sem valor de troca, todavia indispensável à reprodução da força de trabalho, realizado na casa este foi o quinhão que coube às mulheres nessa forma antiga de divisão sexual do trabalho. Em tal reorganização dos papéis sexuais, aos homens correspondeu o mundo público, no qual se desenvolviam as tarefas produtivas e remuneradas, a participação política e a criação científica cultural. Ao mundo privado, o das mulheres, correspondeu o espaço doméstico que era concebido como atividade secundária, pouco valorizada. As atividades mais importantes, com mais recursos, estavam no âmbito público, na esfera masculina (Guimarães, 2005, p.81).
\end{abstract}

O movimento feminista surge como ação organizadora de caráter coletivo, com o objetivo de combater a situação de subordinação das mulheres, em meio das mudanças que marcaram a história da Europa ocidental a partir do século XVIII, vinculando-se ao desenvolvimento da democracia e das revoluções burguesas (Guimarães, 2005). 
As promessas da Revolução Francesa - que a humanidade em todas as suas relações sociais e culturais podia ser regenerada, que as mulheres podiam atingir não só as liberdades civis como também pessoais, que a família, a moralidade e as relações pessoais podiam ser renovadas - fizeram surgir não só um feminismo novo e genuíno como também um novo tipo de antifeminismo, um novo medo de mulheres, e fronteiras políticas que criaram fronteiras sexuais. A criação de uma esfera pública burguesa, em outras palavras, levantou com violência a questão de qual sexo(s) deveria ocupá-la legitimamente. E em todo o lugar a biologia entrava no discurso (Laqueur, 2001, p.242).

O movimento feminista, nesta sua primeira fase, buscou os ideais de igualdade diante da permanência da assimetria sexual, não alterada pela Revolução Francesa e nem pela Revolução Industrial, passando a reivindicar por igualdade política e jurídica para as mulheres. Neste período, o movimento feminista ainda não havia formulado teoricamente uma concepção que confrontasse o determinismo biológico.

Este movimento, tais quais outros movimentos por emancipação do século XIX, mesmo, tendo sua inspiração nas demandas igualitárias da llustração, surgiram também como respostas aos problemas gerados pela Revolução Industrial e pelo Capitalismo. A partir desses ideários, as mulheres fizeram da luta pelo sufrágio feminino sua maior preocupação. Para elas, a conquista do voto feminino poderia resolver outras questões discutidas na época, tais como o direito à propriedade, a reforma do matrimônio e as liberdades sexuais (NYE, 1995).

O debate sobre a situação da mulher passou a fazer parte do discurso científico, filosófico, religioso, artístico e político daquele século. Coexistiam neste período teses que afirmavam a inferioridade feminina - estas eram preponderantes nestas diversas áreas do conhecimento - e outras, que repudiavam a condição de submissão da mulher.

As teses evolucionistas são um exemplo daquelas que reforçavam a inferioridade da mulher, tendo grande peso na teoria social da época, debatiam entre outros temas, a dimensão do cérebro feminino. Enquanto que as teses socialistas, tendo como centro de seus aportes a situação econômica e social da classe trabalhadora, com base no pensamento de Karl Marx e Friedrich Engels trouxeram novas perspectivas sobre a opressão feminina (Guimarães,2005).

Engels em sua obra $A$ origem da família, da propriedade privada e do Estado, redigida em 1884, identifica que a origem da desigualdade e opressão sexual das mulheres estaria na divisão do trabalho baseada no sexo que se deu no capitalismo com o surgimento de classes sociais antagônicas. Dessa forma, 
almeja-se o fim do capitalismo que daria lugar a uma forma de organização social mais desenvolvida, que seria o socialismo, o qual levaria a uma sociedade sem classes, extinguindo-se a opressão das mulheres. De acordo com esta tese, o problema não estaria na esfera da reprodução, mas no surgimento das classes sociais antagônicas numa relação entre capital e trabalho (Piscitelli, 2001; Guimarães, 2005).

Nem todas as feministas que se aproximaram das ideias socialistas concordavam com estas premissas, contra-argumentando que as hierarquias sexuais persistiriam em uma sociedade socialista, uma vez que considerar o "sexo" como contradição secundária e a "produção" como força motriz principal da mudança social, não seria suficiente para a superação da opressão da mulher, pois a produção e a reprodução são igualmente determinantes neste processo (Piscitelli, 2001).

Outra linha de pensamento no século XIX que teve influência no movimento feminista foi o anarquismo, através do qual a participação de muitas mulheres expressava as ideias individualistas, tendo por base a crença de que as mulheres se libertariam graças a sua própria força e seu esforço individual. Emma Goldman - da qual se falará mais adiante ao abordar o tráfico de mulheres - é uma das representantes desta vertente dentro do feminismo (Guimarães, 2005).

Como já foi dito anteriormente, apesar de as feministas da primeira onda, contestarem a subordinação feminina e reivindicarem reconhecimento e igualdade nos espaços públicos, estas não chegaram sobrepor com suas ideias ao que estava posto pelo determinismo biológico.

E é neste contexto do século XIX, que surge o debate sobre o tráfico de escravas brancas em meio às teses do determinismo biológico e a primeira onda do feminismo, com as histórias de mulheres brancas trazidas da Europa para as Américas para serem escravizadas sexualmente por meio da prostituição.

As primeiras concepções e preocupações sobre tráfico de pessoas para fins de exploração sexual de que se tem registro, datam de fins do século XIX e início do século XX, com o movimento surgido na Europa conhecido como "tráfico de escravas brancas".

Este tipo de tráfico tinha como alvo central mulheres brancas europeias (mulheres que seriam "capturadas" e levadas para trabalharem como prostitutas), trazidas para as Américas junto com grandes fluxos migratórios ocorridos naquele período. 
As histórias de "escravas brancas" reforçavam a necessidade do controle do corpo e da sexualidade das mulheres europeias diante da ameaça a valores e interesses sociais, provocada pela liberação e autonomia das mulheres, revelando a moralização da migração quando se trata do deslocamento deste grupo.

Há neste sentido uma ênfase na inocência e na cor da mulher traficada, sendo utilizada para simbolizar o pertencimento da "escrava traficada" à civilização ocidental. Este discurso eurocêntrico indica que através da prática de tráfico seja a pureza da vítima, seja a suposta "superioridade" da civilização ocidental estariam colocadas em perigo (Ausserer, 2007, p.32).

Nas interpretações deste discurso, constata-se que representam metáforas para diversos medos da época sobre mudanças sociais, como por exemplo, o temor sobre a crescente independência (ou do desejo de independência) das mulheres, que ameaçaria a estabilidade da família como "fundamento da sociedade", e ao mesmo tempo, desestabilizaria a integridade da nação.

Este medo referia-se às feministas da época que apesar de incorporarem a ideia da diferença e da complementariedade postos pelo determinismo biológico, começaram a aparecer nos espaços públicos lutando pelo reconhecimento da importância e valor da mulher para a sociedade. Naquela época, as principais demandas feministas eram pelo direito ao voto e à educação. Apesar do feminismo neste momento lutar pela ideia de igualdade, mas não contra o paradigma das diferenças.

O crescimento das grandes cidades da América do Sul que buscavam a todo custo a modernidade europeia e a intensa migração do norte para o sul, foi um dos aspectos que marcaram a segunda metade do século XIX e o início do $X X$.

No Brasil e na Argentina, cidades como São Paulo, Rio de Janeiro e Buenos Aires viviam uma explosão de crescimento e seguiam os exemplos de Londres e Paris, consideradas modelos de cidades modernas e desenvolvidas.

O desenvolvimento dos grandes centros urbanos da América do Sul, em especial no Brasil e na Argentina, foi marcado pelo aumento da prostituição. Com a intensa migração de europeus para países americanos, além da vinda de grandes contingentes de homens e de famílias, verificou-se o aumento da prostituição nas grandes cidades e a consequente vinda de várias prostitutas europeias para os bordéis. 
Havia nos grandes centros certa permissividade à prostituição em face da crença no poder "civilizatório" das mulheres europeias sobre os homens do Novo Mundo, bem como certa aceitação por acreditar na necessidade da prostituição, no resguardo da família e para sanar os impulsos sexuais insaciáveis dos homens.

O mistério e o exotismo causados por essas mulheres sobre a população masculina local, principalmente por aproximar deles um mundo distante e possibilitar a vivência de uma relação amorosa excitante e diferente daquela que estavam habituados, são descritos por Margareth Rago (1991):

\begin{abstract}
A atração pela "polaca" seja ela associada às polonesas austríacas, russas ou judias, fundou-se na constituição de um imaginário voltado para a idealização das regiões distantes, povoadas por raças diferentes, onde ocorriam histórias fantásticas de nobres, num país onde até então grande parte das prostitutas provinha dos contingentes de escravas e ex-escravas negras, principalmente no Rio de Janeiro. Mulheres loiras, ruivas, claras, delicadas, de olhos verdes ou azuis tornavam-se misteriosas e inatingíveis para uma clientela masculina seduzida pelos mistérios fantásticos da vida moderna e impulsionada pelo desejo de desvendar física e simbolicamente os labirintos. Como nunca, o burguês da Belle Époque amou o insólito, sonhou com viagens distantes, desejou experimentar o sabor das aventuras extravagantes, inclusive as sexuais. Essas figuras femininas prometiam realizar suas fantasias eróticas (p.250).
\end{abstract}

Cristiana S. Pereira em seu artigo publicado em 2005, Lavar, passar e receber visitas: debates sobre a regulamentação da prostituição e experiências de trabalho sexual em Buenos Aires e no Rio de Janeiro, no fim do século XIX, analisa os debates em torno da regulamentação da prostituição frente à ameaça moral, provocada inclusive pelo tráfico de escravas brancas.

No século XIX, os temas da prostituição e da escravidão estiveram vinculados, em diferentes partes do mundo. Na Europa, as metáforas da escravidão serviram, na segunda metade do século XIX, para denunciar a violência que envolvia a crescente mobilidade internacional de prostitutas europeias. Mesmo antes, na Inglaterra dos anos 1830, a expressão "escravidão branca" fazia referência tanto à exploração de mulheres em fábricas como à exploração de jovens judias por homens também judeus. No Rio de Janeiro dos anos 1840, quando os médicos começaram a estudar a prostituição como um "fato social", a escravidão era uma referência obrigatória (p.2).Enquanto médicos e homens da lei discutiam a regulamentação da prostituição como medida profilática e moralizante, começavam a preocupar-se com o tráfico de mulheres brancas, a maior parte das prostitutas nas janelas das ruas centrais do Rio eram de escravas negras ( $p .4)$. 
O discurso da época enfatizava a imagem da mulher enganada e ingênua, capturada e escravizada sexualmente, reforçando os apelos à repressão do Estado no combate à prostituição em geral, numa identificação da prostituição com o tráfico.

Sobretudo a partir da década de 1870 , as metáforas de escravidão para falar da prostituição de mulheres europeias se generalizaram de modo simultâneo ao deslocamento maciço de trabalhadores europeus para o continente americano. Embora os movimentos operários continuassem empregando as mesmas metáforas para denunciar a exploração capitalista do trabalho feminino e infantil, a expressão "escravidão branca" passou a ser predominantemente associada à prostituição forçada de mulheres europeias em outros continentes. Mulheres europeias e histórias de "tráfico de brancas" desembarcaram em diferentes partes do mundo, e em cada lugar ganharam dimensões políticas e significados particulares, de acordo com as histórias das relações de trabalho, as configurações de gênero e as práticas locais de comércio sexual (Pereira, 2005, p. 28).

A denominação de "escravas brancas" para mulheres europeias que se dedicavam à prostituição em outros continentes terminava restringindo-as às condições de vítimas passivas e indefesas, o que predispunha que qualquer mobilidade ou outra ação delas fosse sempre interpretada em termos de coerção (Pereira, 2005).

Neste discurso não se mencionava fatores como a vontade de muitas destas mulheres em sair voluntariamente do país em busca de melhores condições de vida, através da migração, que incluía a prostituição como estratégia de sobrevivência nos países de destino.

Todas as autoridades concordavam com que, ao contrário do que imaginavam, as jovens vinham com conhecimento da situação futura, apostando em enriquecer com a comercialização sexual do próprio corpo, e não ignorando o que as esperava na nova terra, ao menos em termos gerais. As autoridades policiais do período, os reformadores sociais e as filantropas que, por vezes, aguardavam-nas nas estações ferroviárias ou nos portos, procurando "salvá-las" das garras das gangues de cafetões surpreendiam-se ao darem-se conta de que a maioria delas não era mera vítima de gigolôs desalmados, algumas já sendo prostitutas em suas terras natais, e que muitas haviam aceitado participar desses deslocamentos migratórios em busca de melhores condições de vida (Rago, 2011, p.264-265)

Destaque deve ser dado ao texto "The Traffick in Women" de Emma Goldman, publicado em 1909.

O texto foi escrito no auge do grande pânico moral sobre o tráfico de mulheres nos EUA, resultando na passagem do Ato Mann, que proibia o 
transporte interestadual de mulheres para "fins imorais". A nova lei destinava-se à repressão da prostituição e foi apoiada por uma série de agentes políticos, inclusive boa parte do movimento de mulheres (Blanchette, 2011).

Para Margareth Rago (2011) Emma Goldman em diferentes frentes de ataque à exploração capitalista, ao imperialismo e à opressão de gênero, foi uma das feministas, de vertente anarquista que ousou discutir assuntos até então pouco enunciados por mulheres, mesmo entre as feministas. $O$ tráfico das "escravas brancas", a prostituição, o casamento e o amor livre compõem um conjunto de temas tratados por Goldman.

Neste texto Goldman foca a sua análise para o que considera mais um uso político dos problemas sociais de sua época do que um real enfrentamento da questão do tráfico de mulheres da Europa Oriental e Ocidental para a América, por gangues especializadas, destinadas à prostituição.

Goldman questiona os reformadores sociais norte-americanos, por não considerar que haja de fato um contingente expressivo de prostitutas estrangeiras nos Estados Unidos trazidas pelo tráfico das "escravas brancas". Segundo seus argumentos, a maioria das prostitutas em Chicago era estrangeira porque haviam vindo sozinhas ou com suas famílias, com a forte imigração europeia iniciada na década de 1880, assim como ela mesma que, ainda jovem, imigrara com sua irmã para tentar a sorte na América, e acabara trabalhando nas fábricas têxteis (Rago, 2011).

Qual é realmente a causa do comércio de mulheres? Não apenas de mulheres brancas, mas também mulheres amarelas e negras! Exploração, é claro, o impiedoso Molloch do capitalismo que engorda com o trabalho mal pago, levando assim milhares de mulheres e garotas à prostituição. Como a senhora Warren, essas garotas pensam - "Porque desperdiçar sua vida trabalhando por alguns centavos por semana na lavagem de pratos e panelas, dezoito horas por dia?" Nossos reformadores, naturalmente, nada dizem a respeito dessa causa. Eles a conhecem bastante bem, mas não vale a pena dizer algo a respeito disso. É mais lucrativo bancar o fariseu, fingir uma moralidade ultrajada, do que ir à raiz das coisas (...) Em nenhum lugar a mulher é tratada de acordo com o mérito de seu trabalho, mas apenas como sexo.

Portanto, é quase inevitável que ela deva pagar por seu direito a existir, a manter uma posição seja onde for, com favores sexuais. Assim, é apenas uma questão de grau se ela vende a si mesma a apenas um homem, dentro ou fora do matrimônio, ou a vários homens. Quer os nossos reformadores o admitam ou não, a inferioridade econômica e social da mulher é a responsável pela prostituição.

No momento atual, nosso bom povo está chocado com a revelação de que, apenas na cidade de Nova York, uma entre cada dez mulheres trabalha numa fábrica, que a média do salário recebido pelas mulheres seja de seis dólares por semana, por 48 a 60 horas de trabalho, e que a maioria das trabalhadoras enfrentem vários meses de inatividade, o que faz com que a média salarial seja de 280 dólares por ano. Em vista desses horrores econômicos, é de se admirar 
que a prostituição e o tráfico de escravas brancas tenham se tornado fatores tão dominantes?(Goldman, 1909[2011], p. 248-249).

Para Emma Goldman o discurso contra o "tráfico de escravas brancas" estaria sendo utilizado muito mais como uma forma de deslocar o foco das deploráveis condições sociais vigentes no país, que forçavam as moças pobres e trabalhadoras a lançarem-se na prostituição. Dizia ela, "é um absurdo apontar para a Europa como o pântano de onde provêm todas as doenças sociais da América" (Goldman, 1909[2011], p.259).

Para Margareth Rago (2011, p.265),

\begin{abstract}
Goldman usa o tema para lançar a sua crítica social e política ao sistema capitalista, à dominação patriarcal, ao conservadorismo moral, em sua própria atualidade. Assim é que, logo de início, estranha a repentina atenção dada ao chamado "tráfico de escravas brancas" pelas autoridades públicas, questionando que se tratasse de um fenômeno totalmente novo e restrito às "brancas". Ela, então, acrescenta as "amarelas" e as "negras", excluídas já na nomeação do fenômeno. Em seguida, numa aproximação maior, Goldman, conhecida também por seu lado irreverente e boêmio, supõe uma intenção moralista, uma manipulação ideológica em desviar a atenção da opinião pública de algo importante para se iniciar uma "cruzada moral contra a indecência", contra a prostituição, os jogos e os bares. Na verdade, afirma, o que se nota com maior clareza é a indiferença das autoridades em relação às prostitutas e à situação de inferioridade social e moral das mulheres, e não algum tipo de preocupação e cuidado[grifo nosso]. Num texto absolutamente crítico, não perdoa os de cima, entre governantes e reformadores, mas também não deixa escapar a metáfora do "bebê" para qualificar um povo que se deixa facilmente seduzir por brinquedos novos, dados por gordos políticos parasitários que precisam ocupar-se com alguma coisa: o grito contra o tráfico de mulheres é um desses jogos, diz ela. Assim, Goldman desmistifica e relativiza o tema desde as primeiras linhas de seu texto.
\end{abstract}

Outro aspecto ressaltado por Rago (2011) e problematizado por Goldman, é que diante da falta de perspectiva nos seus países de origem, muitas mulheres migravam sabendo que iriam se inserir na prostituição, ou porque já tinham esta inserção em seus países ou porque passaram a ver na prostituição uma possibilidade concreta de mudarem de vida. $O$ trecho a seguir mostra bem este argumento:

Contudo, desde que o tema do tráfico sexual voltou à baila entre as décadas de 1970 e 1980, estudos históricos respeitados avaliam que houve um intenso trânsito de mulheres oriundas de regiões empobrecidas da Rússia, Polônia, Romênia e Ucrânia, ou mesmo da França, Espanha e Portugal, destinadas ao mercado sexual nas capitais do Novo Mundo, entre Nova York, Buenos Aires, Rio de Janeiro e São Paulo, nos inícios do século 20 (cf. Bristow, 1982). É possível encontrar inúmeros relatórios oficiais, cartas e outros tipos de documentos trocados, no período, entre as autoridades inglesas da National 
Vigilance Association, fundada em 1885 e da Jewish Association for the Protection of Girls and Women, ambas instaladas em Londres, ou ainda da Association pour la Repression de la Traite des Blanches et la Preservation de la Jeune Fille, criada em Paris, em 1901, e as suas filiais estabelecidas nos países de destino das jovens, em que se discutem com muitos dados as possíveis formas de controle ao tráfico das brancas e de vigilância nos portos (Rago, 1999, p.306-; 2008).

Para além de apontar as causas da prostituição na inferioridade social e econômica da mulher trabalhadora, mais desvalorizada do que o homem pelo fato de ser mulher, Goldman avança em suas reflexões, denunciando a hipocrisia e a misoginia da sociedade moderna, em que as mulheres nunca são vistas pelo mérito de seu trabalho, mas como objetos sexuais. De acordo com a autora, neste sentido as mulheres deviam, portanto, pagar pelo direito de existir e esse pagamento é sexual, dentro ou fora do casamento.

Para Goldman, era a realidade econômica da sobrevivência das mulheres sob o capitalismo que fazia emergir e crescer a prostituição e não, as condições morais das mulheres ou tampouco dos homens que se utilizavam dos favores sexuais (Blanchette, 2011).

\begin{abstract}
Ela situa a prostituição como fruto da exploração, mas de uma exploração que vai muito além do campo sexual e que abrange quase todas as formas de trabalho disponíveis nos horizontes de possibilidades das mulheres de seu tempo. De acordo com Goldman, o capitalismo oferece para a mulher duas opções: trabalhar ou se vender. No segundo caso, a única questão é se vai se vender para um homem só (socialmente aceitável, desde que esteja dentro dos limites do casamento monogâmico), ou se vender para vários. Para Goldman, a diferença entre essas duas posições não é absoluta e sim de grau. (Blanchette, 2011, p.294-295).
\end{abstract}

$\mathrm{Na}$ época, a associação do tráfico com a prostituição servia para representar a degradação moral que a prostituição exercia dentro da sociedade e na própria mulher. E o uso do termo escravidão significava uma maior degradação, conferindo ao indivíduo e à sociedade uma posição de atraso ou mesmo involução - uma vez que se tratava primordialmente de mulheres brancas. Assim, mulheres europeias e histórias de "tráfico de escravas brancas" desembarcaram em diferentes partes do mundo e em cada lugar ganharam dimensões políticas e significados particulares, de acordo com as histórias das relações de trabalho, as configurações de gênero e as práticas locais de comércio sexual (Pereira, 2005). 
Não era por acaso, assim, que o vocabulário empregado para descrever as dinâmicas internacionais da prostituição - escravidão branca, tráfico de brancas, abolicionismo - fosse o mesmo utilizado pelos movimentos contra a escravidão africana no ocidente ao largo do século XIX. Enquanto evidenciava as dimensões de violência, imoralidade, coerção, que caracterizariam a prostituição internacional de mulheres europeias, esse vocabulário legitimava moralmente a intervenção política de certos grupos a favor das vítimas (Pereira, 2005, p.3)

No Brasil ao final do século XIX e durante as primeiras décadas do século $X X$, o intenso debate sobre "as escravas brancas" sugere que esse tema era um dos principais problemas públicos da época.

No entanto as evidências empíricas examinadas por historiadores da época não confirmavam a magnitude atribuída ao tráfico. Pelo contrário, pesquisas feitas nas varas criminais do Rio de Janeiro mostraram que entre 1890 e 1928, os casos ligados ao tráfico internacional de mulheres eram uma pequena porcentagem (Pereira, 2002).

Embora o tráfico de mulheres, de fato, não fosse no período, um fenômeno quantitativamente significativo, a retórica sobre tráfico, no entanto, permitiu, frente à ameaça moral, à sociedade e às famílias brasileiras, a implementação de políticas violentas no sentido de promover a "limpeza" moral das cidades.

\begin{abstract}
Não se sabe ao certo a quantidade de mulheres que para cá vieram traficadas da Europa, principalmente das aldeias pobres da Polônia, Rússia, Áustria, Hungria e Romênia, para serem exploradas na prostituição. Também é difícil precisar quantas vieram por vontade própria ou foram iludidas com promessas de casamento e perspectivas de bons trabalhos, contudo, a referência ao tráfico clandestino de francesas, espanholas, italianas, portuguesas e russas aparece como uma constante nas histórias sobre a prostituição nas décadas iniciais do século XX (Rago, 1991, p. 250).
\end{abstract}

Desta forma, vemos que o discurso anti-tráfico não se baseava apenas em evidências empíricas, mas numa construção de conhecimento marcado por interesses diferenciados dentro de relações de poder. Para Foucault (1978: p.30), "a produção de conhecimento está diretamente relacionada ao poder; e o discurso - que não está separado do poder, mas representa uma forma de exercê-lo através da produção de saberes - pode ser visto como uma forma de poder"

Assim para reduzir a "ameaça do tráfico de pessoas" para a sociedade e ao mesmo tempo, o perigo que corre a vítima, é estabelecido mecanismos disciplinares que vigiam e controlam a possível vítima. 
Desde o século XIX, mulheres que quisessem praticar a prostituição em países estrangeiros, necessitavam da ajuda de terceiros para o êxito da viagem. Normalmente, as mulheres chegavam acompanhadas, ou por maridos (em casamentos arranjados com tal finalidade), ou por amantes, ou por cafetinas disfarçadas no papel de tias ou protetoras, já que a Policia dos Portos exigia das mulheres sozinhas documentos não exigidos a outros imigrantes, como: carteira de identidade do país de origem, atestado policial de boa conduta e bons costumes, e certificado de exercício de uma profissão lícita. Dentro dos parâmetros sociais da época, a mulher que andava sozinha, até que se provasse o contrário, era potencialmente uma prostituta (Menezes, 1992).

Foi no início do séc. XX que muitos países começaram a articular "políticas de prostituição" no sentido de regulamentação estatal da prostituição, debatendo até que ponto os poderes públicos poderiam intervir nas relações sexuais. Naquele momento histórico, as políticas da prostituição se resumiam a dois grupos principais, o regulamentarismo e o abolicionismo, criados na Europa pelas elites dominantes, nos inícios do século XIX.

O sistema de regulação estatal ou regulamentarismo, em sua concepção mais tradicional, vigorou ao longo de grande parte do século XIX em praticamente todos os países europeus. E considerava a prostituição como um fenômeno social não erradicável e, como tal, precisava limitar os danos que podia causar na sociedade. Desde que cumprissem as regras estabelecidas pelo Estado, não existiria penalização da prostituta, que era considerada uma prestadora de serviços para o cliente considerado consumidor e para quem fazia desta atividade um negócio. Os consumidores ficavam de fora do controle regulamentaristas.

Para os regulacionistas a prostituição representa um "mal necessário" e a "prostituta" uma "mulher caída", um "agente que transmite doenças", uma "aberração sexual", devendo concentrá-la a exemplo do sistema francês, em "casas de tolerância", onde esta ficaria reclusa e sendo submetida a exames médicos periódicos obrigatórios no combate a difusão de doenças venéreas.

As prostitutas eram em geral vistas como um produto improdutivo: porque eram mulheres públicas; porque seus órgãos reprodutivos sujeitavam-se a um tráfico pesado; porque nelas o sêmen de vários homens diferentes era misturado junto; porque seus ovários, através da superestimulação, quase sempre apresentam lesões mórbidas; porque suas trompas de Falópio eram fechadas por excesso de coito; ou, mais importante ainda, porque como não tinham afeição pelos homens com quem faziam sexo, eram consideradas estéreis ou, pelo menos, incapazes de terem filhos (Laqueur, 2001, p.275) 
Por outro lado, o movimento de abolicionistas, impulsionado pelas feministas, desencadeou no fim do século XIX na Europa uma corrente contra o regulamentarismo. Estas feministas consideravam a prática da prostituição como escravatura humana e as ações regulamentaristas autoritárias, pois não reconheciam os direitos individuais de prostitutas, sendo inclusive questionáveis em termos de profilaxia das doenças venéreas.

Contrapondo o discurso regulamentarista Josefine Butler, uma feminista da Federação Abolicionista Internacional, afirmava em 1875: "se a prostituição é uma necessidade social, uma instituição de saúde pública, então os ministros, os prefeitos da polícia, os altos funcionários, os médicos que a defendem, faltam a todos os deveres, não Ihes consagrando as suas filhas"(Tavares,s.d, p.2).

Estes atos são criticados pelas abolicionistas também por conceder ao Estado o poder de controlar e examinar todas as mulheres suspeitas de se prostituírem e de colocar, deste modo, todas as mulheres "respeitadas" em perigo de se tornar alvo destas políticas e de perder a própria "boa reputação" (Doezema, 2000).

Para as abolicionistas a prostituta representaria uma vítima que deve ser resgatada e reabilitada.

As abolicionistas ganharam força em diversos países europeus, unindose a grupos dos chamados "reformadores da pureza social" que visavam combater os "vícios imorais" da sociedade, além da prostituição ${ }^{35}$.

A ideia de que os países regulamentaristas, adotando ideias autoritárias e atrasadas, se transformavam em locais de tráfico, ganhou tanta força que no começo do século XX a maior parte da mobilidade internacional de mulheres europeias que viajavam sozinhas para a América do Sul tendia a ser interpretada como uma mobilidade forçada - como tráfico, não como emigração (Pereira, 2005).

\begin{abstract}
A ausência de regulamentação no Rio de Janeiro não implicou um descaso estatal com o tema, e sim uma maior concentração das medidas de controle das prostitutas nas mãos das autoridades policiais...uma certa política que resultou de múltiplos conflitos entre autoridades policiais, prostitutas e autoridades judiciárias, e que se caracterizou por instáveis regras não escritas e por negociações locais e pontuais. Sua implementação nas primeiras décadas republicanas, provocou a concentração de prostitutas notórias em ruas próximas ao centro da cidade, de modo não tão diferente daquele que predominou em cidades latino-americanas que adotaram sistemas regulamentaristas (Pereira, 2005, p.5).
\end{abstract}

\footnotetext{
${ }^{35}$ Cf. Doezema (2000, p.27); Derks (2000, p.3).
} 
De acordo com Pereira (2005) no Rio de Janeiro, em que a maior parte do trabalho era associado à escravidão, reconhecer que uma mulher de maior idade podia ser coagida ao trabalho sexual não era nada difícil. Nas teses médicas sobre prostituição que começaram a aparecer em meados do século XIX, a prostituição recorrentemente associada à escravidão, considerando que as prostitutas, escravas ou livres, eram ameaças sociais.

\begin{abstract}
Em um contexto de ascensão de uma burguesia europeizada e instauração ou consolidação de certo modelo moral de família, a prostituta representava os degredados que vinham para a "nova metrópole" em busca de oportunidades, e pela atividade que desempenhavam, atacavam fortemente a moral que deveria estar solidificada em indivíduos e famílias. Assim, todos os mecanismos de controle social voltavam-se contra esta atividade, construindo-se a importância de controlar ou erradicar a prostituição. Nesse quadro, a doença também desempenhava papel fundamental, na medida em que a mulher que se prostituía era vista como um foco ambulante de contaminação da "sífilis merecida", que entrava nos lares através dos maridos infiéis que contaminavam suas esposas (Ferreira, 2009, p.12).
\end{abstract}

A prostituição associada à escravidão transformou-se nos fins do século XIX, em um assunto debatido pelo Estado brasileiro, que não assumiu claramente nem uma postura regulacionista e nem abolicionista. Não se questionava a necessidade de intervenção deste na prostituição, mas até onde este poderia invadir as relações de âmbito privado, como entre senhores e escravas, visto a existência de muitos casos de escravas que eram forçadas a se prostituir pelo seu senhor/ proprietário.

Em meio à intensificação dos debates sobre o fim da escravidão, a intervenção estatal para sancionar a exploração do trabalho sexual de uma prostituta era considerada por todos consultados como escandalosa. Mas esta postura não implicava recusar a vigilância moral sobre o comércio sexual. Assim defendiam com veemência outras medidas de vigilância, que iam desde localizar as prostitutas em certas partes da cidade, até a ampliação das atribuições da polícia (Pereira, 2005, p. 9).

Viu-se que no Brasil o "problema com a prostituição", embora não tendo início com as histórias de tráfico de "escravas brancas", foi com elas que o trabalho sexual e doméstico tornou-se um problema político ao longo da segunda metade do século XIX, quando passou a associar a prostituição à escravidão pelo tráfico de mulheres.

Nesse sentido, as histórias de tráfico também serviam para justificar as constantes campanhas policiais de "saneamento moral" pela cidade, 
corroboradas por uma ordem médica a serviço do Estado. Na prática, estas campanhas seguiram objetivos bastante distantes do combate ao tráfico e principalmente distante da proteção e ajuda a estas mulheres traficadas, recaindo mais numa vigilância sobre habitações coletivas de trabalhadores e expulsão de prostitutas do Centro da cidade do Rio de Janeiro, e a uma rotina de suspeição policial sobre imigrantes de certas nacionalidades (Pereira, 2006).

\section{2 \\ 0 tráfico de mulheres no debate dos movimentos feministas contemporâneos}

Foi no final dos anos 1960 e início de 1970 em oposição à tese de que as raízes da diferença entre homens e mulheres estariam na biologia de seus corpos, predominante desde o Renascimento, que as feministas adotam a concepção da constituição social do caráter humano, passando a se pautarem na noção de gênero.

A crítica ao modelo essencialista da diferença sexual passa a ser incorporada pelas teorias feministas com a utilização da categoria gênero, desmistificando a universalização do modelo da dominação masculina, em que a mulher só tem lugar como objeto, desencadeando um importante processo de desconstrução da visão com base no determinismo biológico, dando início à segunda onda do feminismo.

A segunda onda do feminismo, afirmou a necessidade de reconhecer as diferenças e denunciar as diversas formas de dominação masculina presentes e reforçadas na sociedade capitalista.

O feminismo passa a se situar entre as correntes interpretativas críticas que, ao longo do século $X X$, manteve uma atitude de supeita frente às práticas culturais, os poderes e saberes monológicos e oficiais e as grandes totalizações - metafisicas, ontológicas, históricas- universalistas. A partir do conceito de das politicas culturais da gênero, o feminismo denunciou que não existe representação da diferença sexual independente representação (Harding, 1993).

No início da segunda onda feminista, ao mesmo tempo em que a influência do biologismo está sendo criticada, também era invocada, ao colocar o 
biológico como base sobre a qual os significados culturais são construídos (Nicholson, 2000).

Gênero se refere à construção social do sexo, na caracterização do masculino e feminino, que são apreendidos por homens e mulheres mediante o processo de socialização e de acordo com as normas culturais da sociedade em que estejam inseridos, sendo condicionados diferentemente para cumprirem funções sociais específicas e diversas, do ser- homem e do ser-mulher, que serão interiorizadas como se fossem naturais.

\begin{abstract}
Sujeitos de seu tempo, imersos em um conjunto específico de relações sociais historicamente situadas, cada ser-mulher e cada ser-homem têm um grupo originário e estão submetidos às regras de comportamento que se firmam conforme a ética hegemônica. Assim sendo, sob o ponto de vista da construção de sua especificidade de mulher e de homem, são determinantes sua classe, raça, religião e a forma de inserção na sociedade. Deste modo, a partir dessas variáveis fundamentais, se constroem o ser-mulher e o ser-homem" (Guimarães, 2005, p.90).
\end{abstract}

Para Nicholson (2000), "o gênero tem suas raízes na junção de duas ideias importantes do pensamento ocidental moderno: a da base material da identidade e a construção social do caráter humano (...) o conceito de 'gênero' foi introduzido para suplementar o de 'sexo', não para substituí-lo"(p.2-3).

Desta forma não só o "gênero" não era visto como substituto de "sexo" como também "sexo" parecia essencial à elaboração do próprio conceito de "genero".

Um dos primeiros estudos que problematizará esta relação sexo/gênero será o artigo The Traffic in Women: notes of the 'political economy' of sex (1975) de Gayle Rubin, onde lança a expressão "sistema sexo/gênero", definindo como o "conjunto de acordos sobre os quais a sociedade transforma a sexualidade biológica em produtos da atividade humana, e nos quais essas necessidades sexuais transformadas são satisfeitas"( p.1), assumindo o biológico como base sobre a qual os significados culturais são constituídos.

O estudo de Rubin apesar de não ter como objeto o tráfico de mulheres para fins de exploração sexual, e sim a análise do intercâmbio de mulheres como forma de perpetuar sistemas de parentesco, torna-se útil na compreensão da mulher como valor de troca, onde elas não têm direitos sobre si mesmas, o que se assimila à lógica do tráfico de mulheres para fins sexuais na contemporaneidade, concebendo a mulher enquanto mercadoria a ser comercializada. 
Rubin começa o texto Trafico de Mulheres falando numa abordagem à Marx e Engels tecendo uma crítica a obra "A Origem da Família, da Propriedade Privada e do Estado", de Friedrich Engels, considerada dentro da teoria marxista, aquela que mais aborda a subordinação da mulher.

Em entrevista com Judith Butler, Rubin avalia que naquela época havia uma forte influência do marxismo entre os intelectuais e no pensamento feminista. Porém o marxismo não respondia de forma satisfatória a análise das relações de gênero.

\begin{abstract}
Há um imenso legado marxista no feminismo, e o pensamento feminista tem uma grande dívida com Marxismo. Em certo sentido, o marxismo permitiu que as pessoas levantassem toda uma série de questões que o próprio marxismo não podia responder satisfatoriamente, como questões relacionadas à sexualidade ou ao gênero, uma vez que priorizavam temáticas como classe social, trabalho, relações e modos de produção. O gênero, nesse contexto, não era priorizado, e se era, tinha um cunho bastante essencialista (Butler \& Rubin, 2003, p. 158).
\end{abstract}

Assim, na tentativa de explicar a gênese da subordinação universal da mulher, Rubin vai concentrar sua análise em teóricos que tratavam dessa temática na época como o antropólogo Claude Lévi-Strauss e o psicanalista Sigmund Freud.

Rubin mostra como funciona o sistema sexo/gênero, principalmente a partir da leitura da obra $A$ estrutura elementar do parentesco de Lévi-Strauss, na qual observa que para o autor o parentesco aparece como uma imposição da organização cultural sobre a procriação biológica, estando esta impregnada pela consciência da importância da sexualidade na sociedade humana. Para ele a essência dos sistemas de parentesco está no intercâmbio de mulheres entre homens, tendo construído assim uma teoria da opressão sexual.

Lévi-Strauss destaca que há uma regularidade enorme em diversas sociedades do globo terrestre que proíbe o casamento entre pessoas da mesma organização parental (família, totem, etc), ou seja, o incesto. O tabu do incesto é, portanto e antes de qualquer coisa, segundo ele, uma garantia de que tais trocas sejam realizadas entre famílias e grupos diferentes.

Lévi-Strauss añadió a la teoría de la reciprocidad primitiva la idea de que el matrimonio es una forma básica de intercambio de regalos, em que las mujeres constituyen el más precioso de los regalos. Sostiene que el mejor modo de entender el tabú del incesto es como un mecanismo para asegurar que tales intercambios tengan lugar entre familia y entre grupos...El resultado del regalo de una mujer es más profundo que el de otras transacciones con regalos, porque la 
relación que se establece no es sólo de reciprocidad sino de parentesco (Rubin,1975, p.109).

Assim, sendo as mulheres eram o objeto das transações, os homens são então, aqueles que possuem o poder de dá-las ou tomá-las. Porém estas não podem dar a si mesmas. Num sistema deste tipo, as mulheres não estão em condições de receber os benefícios de sua própria circulação, pois quem os recebe são aqueles que realizam o intercâmbio, os homens. Neste sentido as mulheres têm um grande valor para o estabelecimento de relações de parentesco através do matrimônio, e na manutenção das relações sociais.

Para Rubin (1975), o "intercâmbio de mulheres" é um conceito sedutor e vigoroso, pois possibilita o exame da opressão de mulheres em sistemas sociais primitivos, antes do surgimento da biologia, citando exemplos etnográficos e históricos do tráfico de mulheres, através do matrimônio, tomadas em batalha, trocadas por favores, enviadas como tributo, compradas e vendidas.

Porém, segundo ela, não dá para dizer que "troca de mulheres" é base da cultura, pois significaria dizer que o projeto feminista deveria abolir a cultura e colocar no lugar algo que não tenha como base a opressão das mulheres. Obviamente que não é necessário "abolir a cultura" para que haja a emancipação feminina, afinal a cultura é, por definição, inventiva, dinâmica.

Ressalta Rubin (1975, p.10) que "a troca de mulheres é uma abreviação para expressar que as relações sociais de um sistema de parentesco especificam que os homens têm certos direitos sobre suas parentas e que as mulheres não têm os mesmos direitos sobre si mesmas ou sobre seus parentes do sexo masculino". Dessa maneira, ela deixa claro que não acredita que o "tráfico de mulheres" seja suficiente para explicar a subordinação feminina.

De acordo com a autora na maior parte da história humana os homens foram intercambiadores e não o objeto do intercâmbio. Mas no caso das mulheres, estas foram objetos de transações como escravas, servas e prostitutas, além de outras situações, por serem simplesmente mulheres.

O "intercâmbio de mulheres", observa Rubin, não é em si uma definição da cultura nem de um sistema em si mesmo, mas tal concepção é uma apreensão de alguns aspectos das relações sociais de sexo e gênero, que revela tipos diferenciados de direitos que pessoas têm sobre outras.

Assim nas relações de parentesco, as mulheres são valores sociais e por isso são "protegidas" pelos homens, pois são valiosas na constituição destas relações. 
Por outro lado, mulheres que não estejam presas às estruturas de parentesco ou outras estruturas que não as contém e nem as protejam, tornamse alvo de ações moralizantes e de controle por tal comportamento ser visto com estranhamento e fora dos padrões dentro da assimetria de gênero.

No fim da década de 1980, a historiadora estadunidense Joan Scott, influenciada pelas correntes pós-estruturalistas que se inspiraram no pensamento de Foucault e Derrida, esquematizou uma nova forma de se pensar gênero, a partir de uma crítica a outras concepções, inclusive a do sexo/gênero, que, em sua opinião, eram incapazes de historicizar a categoria sexo e o corpo.

Scott (1996) realça o caráter relacional das definições de feminismo e masculino e define "gênero é um elemento constitutivo de relações baseadas nas diferenças percebidas entre sexos, e o gênero é uma forma primeira de significar as relações de poder" (p.11-12).

Desta forma não se refere apenas às ideias, mas também às instituições, às estruturas, às práticas cotidianas, como também aos rituais e a tudo que constitui as relações sociais. Portanto, o gênero não reflete a realidade biológica primeira, mas constrói o sentido dessa realidade.

O discurso é um instrumento de ordenação do mundo, e mesmo não sendo anterior à organização social, ele é inseparável desta. Portanto, o gênero é a organização social da diferença sexual. Ele não reflete a realidade biológica primeira, mas ele constrói o sentido desta realidade. A diferença sexual não é a causa originária da qual a organização social poderia derivar. Ela é antes uma estrutura social movente, que deve ser analisada nos seus diferentes contextos históricos (Scott, 1998, p. 115)

Um dos avanços aos estudos de gênero trazido por Scott foi ultrapassar o seu uso puramente descritivo, no qual o gênero é usado como sinônimo de mulher, ou seja, confundindo com a variável sexo e usá-la como categoria de análise buscando observar como o gênero funciona nas relações sociais, e como ele dá sentido à organização e a percepção do conhecimento histórico (Guimarães, 2005).

Examinar gênero concretamente, contextualmente e de considerá-lo um fenômeno histórico, produzido, reproduzido e transformado em diferentes situações ao longo do tempo. Esta é ao mesmo tempo uma postura familiar e nova de pensar sobre a história. Pois questiona a confiabilidade de termos que foram tomados como auto evidentes, historicizando-os. A história não é mais a respeito do que aconteceu a homens e mulheres e como eles reagiram a isso, mas sim a respeito de como os significados subjetivos e coletivos de homens e mulheres, como categorias de identidades foram construídos (Scott, 1994, p.19). 
$\mathrm{Na}$ contemporaneidade, as diversas concepções surgidas a partir do movimento feminista inicial, permite que não se fale de feminismo, mas de feminismos.

O debate contemporâneo sobre o tráfico de mulheres, emergirá em meio às diferentes concepções dentro do movimento feminista internacional, direcionado para o debate sobre a prostitutição, que vem proporcionando divergências e conflitos que estão longe de um consenso.

Durante os anos 70 e 80, nos EUA e em Inglaterra, as profissionais do sexo começaram a organizar-se contra a criminalização feita pelo Estado e contra o assédio das forças policiais. Identificavam-se como trabalhadoras do sexo e exigiam que a prostituição fosse reconhecida como trabalho. Tiveram o apoio de algumas organizações feministas da época.

Depois dos anos 80, a tensão ideológica e estratégica entre as feministas que reconheciam a prostituição como uma atividade e as que a definiam como uma violência contra as mulheres provocou uma grande clivagem no movimento feminista internacional.

Os dois entendimentos constroem dois sujeitos distintos e representam concepções teóricas diversas. Por um lado, há a teoria feminista radical enraizada no discurso moderno, na qual a lógica discursiva da vitimização exerce um papel importante e que concebe um sujeito- reprimido. Por outro lado, está uma postura feminista fundamentada no discurso pós- moderno, que se opôs à fixação de significados e desenvolve o sujeito resistente (Scoular Apud Ausserer, 2007, p. 80)

As posições abolicionistas das feministas radicais continuam a ser fortemente defendidas tanto por posições conservadoras e moralistas, como por correntes do feminismo internacional que consideram a legalização da prostituição como uma cobertura legal à escravatura sobre as mulheres. São as feministas radicais que introduzem nos anos de 1970 o conceito de patriarcado como dominação masculina estrutural e chave de explicação para a subordinação das mulheres na sociedade.

E para elas existem práticas hierárquicas na sociedade, que legitimam e fortalecem a subordinação de mulheres e a prostituição é uma destas práticas.

Para Pateman (1993),

Quando os corpos das mulheres estão à venda como mercadorias no mercado capitalista, os termos do contrato original não podem ser esquecidos; a lei do direito sexual masculino é afirmada publicamente, e os homens recebem um 
reconhecimento público enquanto senhores sexuais das mulheres - e é isso que está errado com a prostituição (p. 305).

Assim, "argumentam que a distinção entre 'prostituição forçada' e 'prostituição livre' é uma abstração e que a prostituição não pode ser equiparada a uma profissão, pois o corpo não pode ser objeto de uma transação financeira" (Tavares, s.d., p. 6-7).

Consideram ainda que as mulheres envolvidas na prostituição são vítimas, devendo voltar os esforços para a retirada delas da prostituição: "se as mulheres sofrem violências na prostituição, não é porque as leis não as protejam, mas porque o uso das mulheres por parte dos homens na prostituição é o reflexo de uma cultura de dominação das mulheres" (Hofman, 2002, p. 137).

Assim o sujeito de preocupação principal é "a mulher", que deve ser resgatada de séculos de atribuição misógina e patriarcal. "A mulher" é constituída através da experiência em comum da opressão no patriarcado, como um sistema de dominação, que se manifesta especialmente no controle da sexualidade feminina através dos homens.

Neste sentido a constituição da prostituta como vítima, a estabelece como identidade que se baseia na dor e no sofrimento que caracteriza um "sujeito-vítima". Para que este discurso funcione, então, é necessário reestabelecer a categoria de prostituta como vítima, que deve ser resgatada ou como outra, que deve ser "civilizada" (Ausserer, 2007).

As prostitutas são vistas como mulheres desviadas da norma sexual, e, por isso mesmo devem ser resgatadas (vítimas) ou controladas (subversivas).

No enfrentamento ao tráfico de mulheres nos EUA, a postura abolicionista das feministas radicais que associam o tráfico à existência da prostituição- vista como uma violência masculina contra as mulheres, sem distinção entre prostituição forçada e voluntária - encontrou ressonância nos grupos religiosos conservadores. Tais grupos, mesmo distantes da visão feminista, tomarão para si este discurso no combate ao tráfico, principalmente para fins sexuais, considerando-o a decadência dos valores americanos e da moral em geral (Ausserer, 2007).

As feministas radicais abolicionistas, no entanto, difundem o próprio discurso de salvação, entrando em coalizões surpreendentes para alcançar os próprios objetivos. Assim, nos EUA, elas entraram em uma aliança com a direita religiosa, tendo um impacto significativo na política contra o tráfico humano norteamericano. As duas lógicas discursivas têm como objetivo em comum a erradicação da prostituição: as feministas radicais defendem esta erradicação 
porque a prostituição representaria o "epítome da subordinação da mulher no patriarcado"; e os evangélicos, porque lutam contra a imoralidade na sociedade, e concebem a prostituição como a expressão da decadência dos valores (americanos)... levando a uma maior vigilância de mulheres que viajam ou de migrantes em geral, como também a um aumento de controle e do estigma das prostitutas, em vez de fortalecer e de proteger as pessoas traficadas (Ausserer, 2007, p. 112)

Enquanto as feministas radicais discutiam o resgate de mulheres de situações de tráfico, defensores do livre mercado e fundamentalistas cristãos se uniam, respectivamente, na guerra contra o terrorismo e a migração irregular e, a favor de valores familiares tradicionais.

Outra corrente dentro do feminismo tem se distanciado das posições abolicionistas por entenderem que estas estão desajustadas da realidade atual.

As feministas tidas como pós-modernas, que defendem os direitos das trabalhadoras do sexo, não compartilham da opinião das abolicionistas quanto à vitimação das mulheres que vivem da prostituição.

Kamala Kempadoo (2005, p.61-62) é uma das representantes deste grupo que luta pela desconstrução do discurso hegemônico de tráfico e da prostituição ao mostrar que as mulheres devem ser concebidas como sujeitos atuantes, autodeterminados e posicionados de maneira diferente, capazes não só de negociar e concordar, mas também de conscientemente opor-se e transformar relações de poder.

Segundo a crítica das feministas pós-modernas, então, o enfoque extremo no fator crucial e onipotente do patriarcado por parte das feministas radicais, leva-as a invocar continuamente o poder masculino sobre o feminino, perpetuando assim o imaginário da dominação, sem visionar uma saída a esta dinâmica. Assim, por exemplo, a interpretação da prostituição como prática emblemática da opressão feminina no patriarcado, não permite perspectivas alternativas, negando vozes diferenciadas das trabalhadoras do sexo (Agustin, 2005).

Para estas feministas as posições abolicionistas ignoram a situação das mulheres envolvidas na prostituição, ao não serem criadas condições para que estas possam ter segurança social e direitos capazes de reforçar a sua autonomia e lutar contra a exploração e o arbítrio dos clientes, sendo a favor da legalização da prostituição que confira direitos às mulheres.

O tráfico deve ser fortemente combatido assim como a exploração forçada da prostituição. Consideram, ainda, que devem ser criadas condições sociais e econômicas para quem quiser sair da prostituição. 
Este grupo feminista pós-moderno denuncia a postura do feminismo abolicionista, porque fundamenta a própria política no estabelecimento de uma identidade fixa, construída na base da opressão.

Deste modo, em contraponto ao discurso moderno, o discurso feminista pós-moderno visa através da criação de um espaço de discurso aberto às transformações, desafiar as hierarquias na constituição do sujeito, que é modificado segundo o contexto e as negociações mantidas.

Para Caroline Ausserer (2007, p.112) "a postura crítica, então, propõe o rompimento desta dinâmica através de uma leitura pós-moderna do sujeito (prostituta)... considerada nem inerentemente opressiva, nem subversiva, mas que o significado é continuamente negociado".

Nesta abordagem as mulheres são consideradas como sujeitos atuantes, autodeterminadas e capazes de negociar e concordar, mas também de se oporem conscientemente e transformar as relações de poder seja nas instituições de escravidão, casamento, casa ou mercado de trabalho (Kempadoo, 2005).

As ações das mulheres podem ser plurais: podem reescrever ou contestar a dominação e controles masculinos, sexualizados a partir de determinadas condições históricas e contextos culturais específicos.

A prostituição não é definida como uma violência contra as mulheres são as condições de vida e de trabalho que as mulheres podem viver no trabalho sexual e a violência e o terror que aprisionam esse trabalho no setor informal que são considerados como violação dos direitos das mulheres e, portanto, considerados como tráfico.

Opõem-se à convergência entre a prostituição e o tráfico, insistindo que unicamente a prostituição forçada deveria ser entendida como tráfico. E que a extinção da prostituição, através da sua criminalização, não constitui solução contra o tráfico, mas só agravaria a situação de fragilidade das trabalhadoras do sexo, que passariam a ser tratadas como criminosas, reivindicando uma distinção entre prostituição voluntária e prostituição forçada e o fortalecimento dos direitos das trabalhadoras do sexo.

Entretanto não se pode deixar de considerar, que mesmo na prostituição voluntária é possível que haja mulheres traficadas, não sendo o deslocamento e suas motivações o que caracterizaria o tráfico, mas a existência da violência e da exploração na violação de direitos humanos.

Esta perspectiva rejeita a ideia que a prostituição é inerentemente degradante e a considera como uma forma de serviços, de trabalho, e traçam 
nítidas distinções entre a prostituição voluntária exercida por adultos e a prostituição forçada e a prostituição infantil. A ideia central é que a exploração e, inclusive, o tráfico, não estão automaticamente vinculados à existência da indústria do sexo.

Considera-se que quem trafica se beneficia da irregularidade da migração e da ilegalidade do trabalho sexual comercial. Esses fatores são a fonte do poder e controle que exercem sobre os/as migrantes. Nestes casos as leis que impossibilitam a migração e o trabalho sexual legal constituem os principais obstáculos para os/as migrantes que se inserem na indústria do sexo no exterior (Piscitelli, 2008).

As distintas concepções da prostituição e do tráfico provocam uma polêmica entre estes grupos feministas, visto que o pano de fundo são visões morais que se sustentam em bases epistemológicas opostas, conduzindo a diferentes implicações políticas sobre o assunto.

\section{3 \\ Gênero nas imagens das campanhas de combate ao tráfico de pessoas}

Neste item propõe-se a análise das imagens das campanhas desenvolvidas nos últimos anos, em diversos países, como estratégia no combate ao tráfico de pessoas, através da sensibilização e alerta sobre esta nova forma de escravidão moderna.

Em todas as imagens utilizadas nas campanhas, fica visível que o tráfico é um crime que envolve a coação, o uso da força, o rapto ou abuso de poder, realizado por meio do deslocamento para fins de exploração.

Embora o tráfico de pessoas tenha diversas finalidades, como o trabalho forçado em diversos ramos de atividade, inclusive para a exploração sexual, e, não só atinge mulheres, mas também crianças e adolescentes e homens adultos, vê-se nas campanhas anti-tráfico o foco exclusivo na figura da mulher e na exploração para fins sexuais, como bem mostra as imagens que se seguem.

As imagens 1, 2 e 3 trazem como ênfase o transporte ilegal e clandestino, apresentando a figura da mulher capturada, aprisionada e enjaulada, numa 
mensagem subjacente dos riscos que correm mulheres sozinhas que querem emigrar.

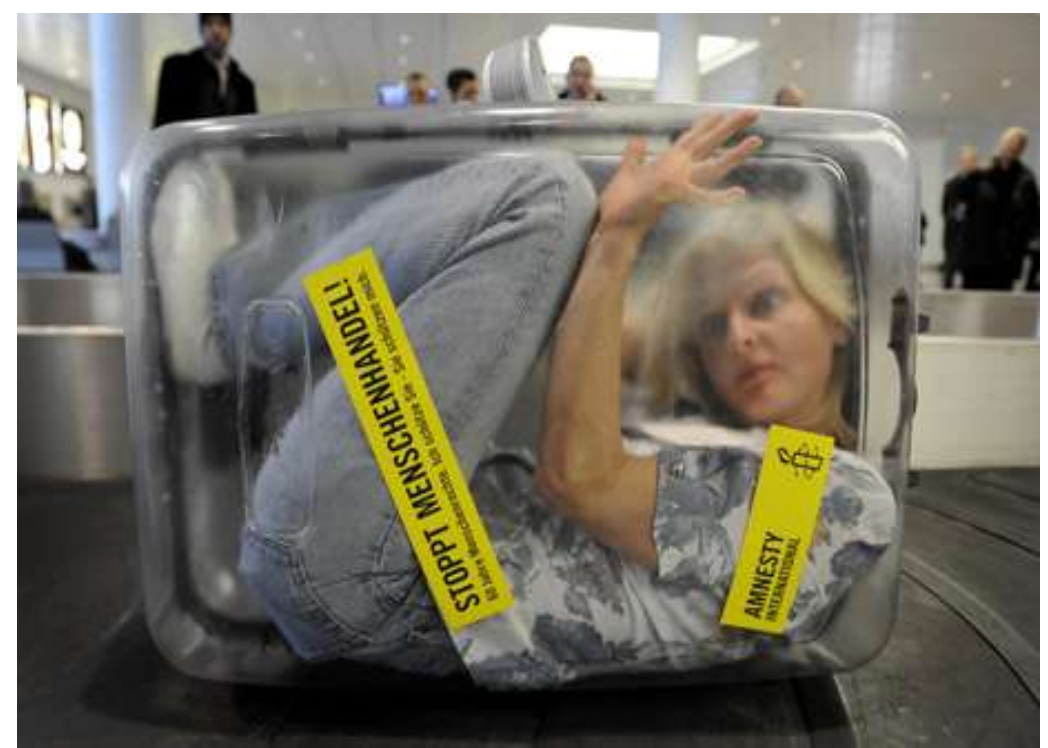

Imagem 1- Campanha vinculada na Alemanha em 2008.

Esta imagem vinculada na Alemanha e produzida pela Anistia Internacional no ano de 2008, mostra uma mulher presa numa mala sendo transportada pelas esteiras rolantes de um aeroporto. Simbolicamente representa o aprisionamento e a clandestinidade com a entrada irregular, mostrando a mulher como um objeto transportado através das fronteiras. 


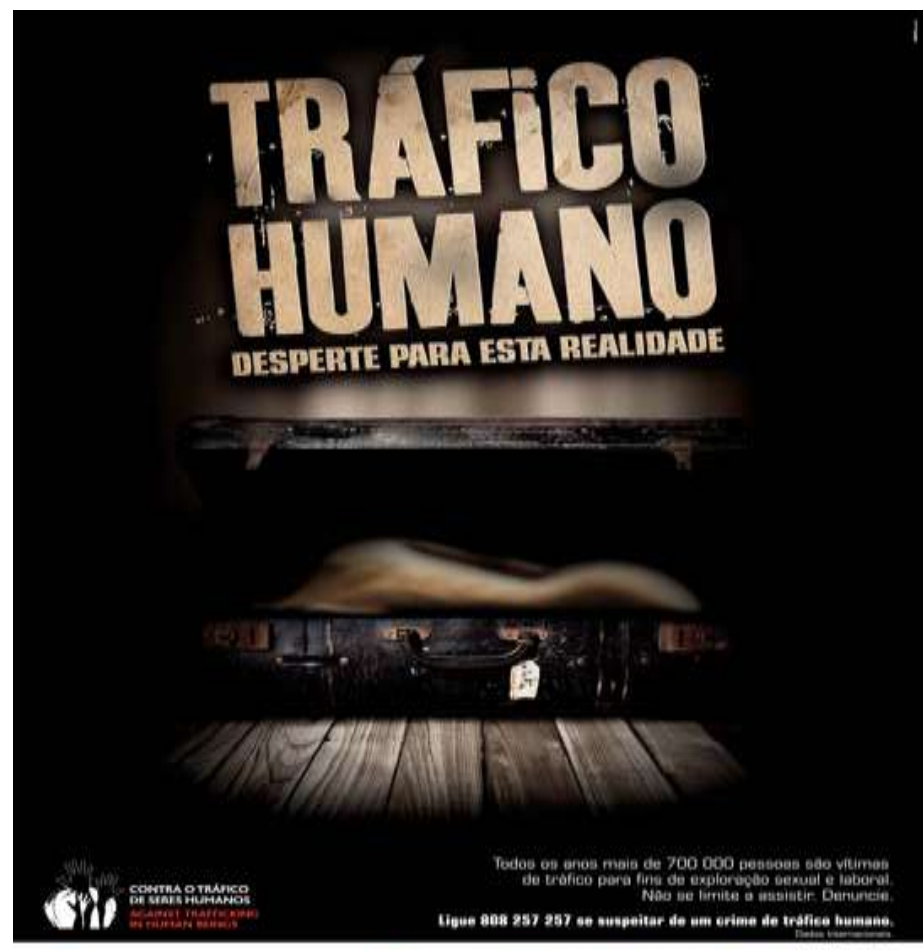

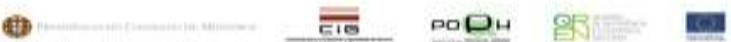

Imagem 2- Campanha vinculada em Portugal em 2008.

Esta campanha de sensibilização e informação que teve como slogan "Tráfico Humanos: Desperte para esta realidade" e "Denuncie". A imagem mostra parte de um corpo nu de mulher em uma mala de viagem, remetendo à fragmentação de quem é explorada sexualmente e a clandestinidade.

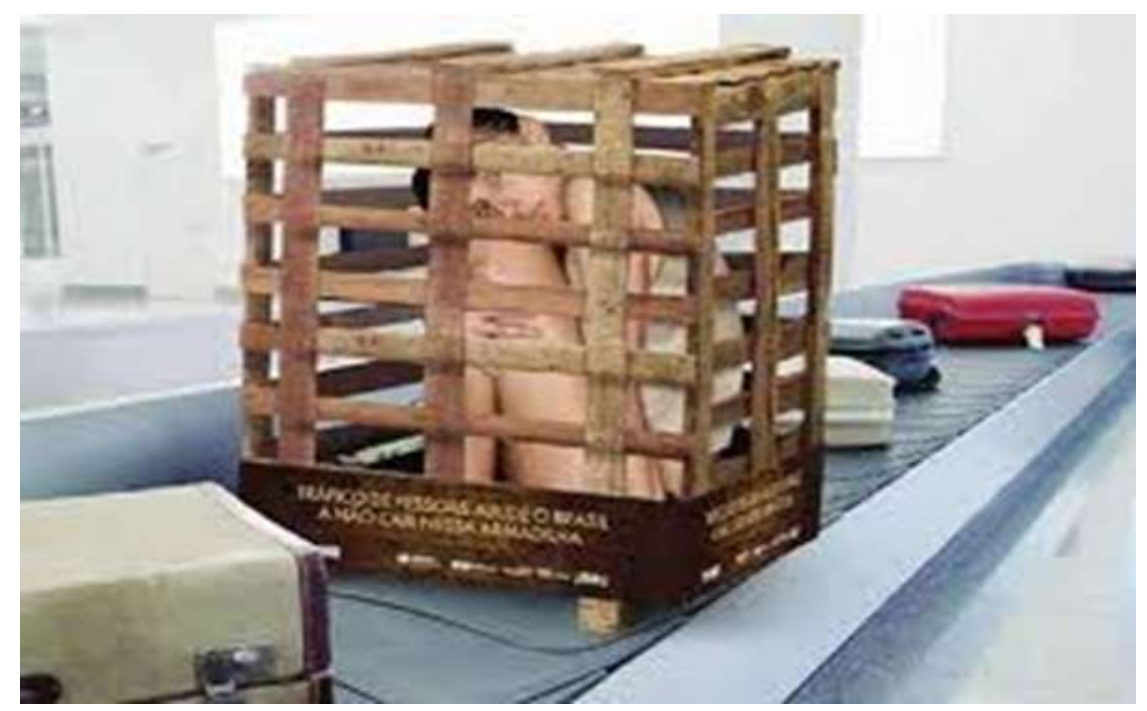

Imagem 3- Campanha vinculada no Brasil em 2010. 
Esta campanha lançada pela Secretaria Nacional de Justiça, do Ministério da Justiça, faz uma analogia às armadilhas usadas para capturar animais ao utilizar uma mulher enjaulada e o slogan "Tráfico de pessoas, ajude o Brasil a não cair nessa armadilha", chamando atenção para os perigos, que principalmente mulheres, podem correr ao tentar sair do país.

As imagens 4, 5 e 6 se reportam mais diretamente à prostituição, quando apresentam mulheres acorrentadas e ofertadas como mercadoria para consumo.

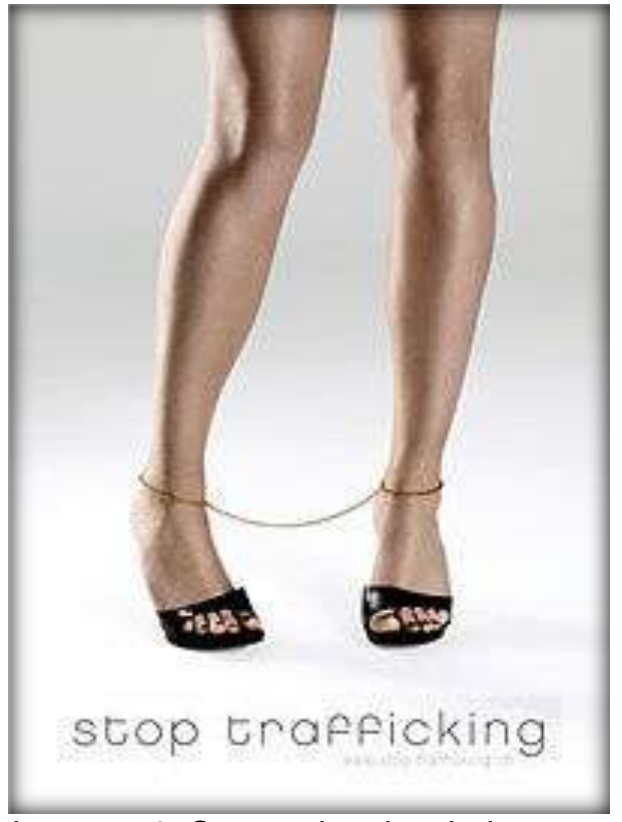

Imagem 4- Campanha vinculada na Suíça em 2008.

Esta imagem vinculada em um site suíço, coordenado pela Anistia Internacional, no Dia Internacional da Mulher, numa campanha chamada "Euro 2008 contra o tráfico de mulheres" pede mais proteção às vítimas deste tipo de "escravidão moderna".

A imagem mostra aparentemente uma mulher, jovem e acorrentada, simbolizando a escravidão e o cerceamento do direito de ir e vir. 


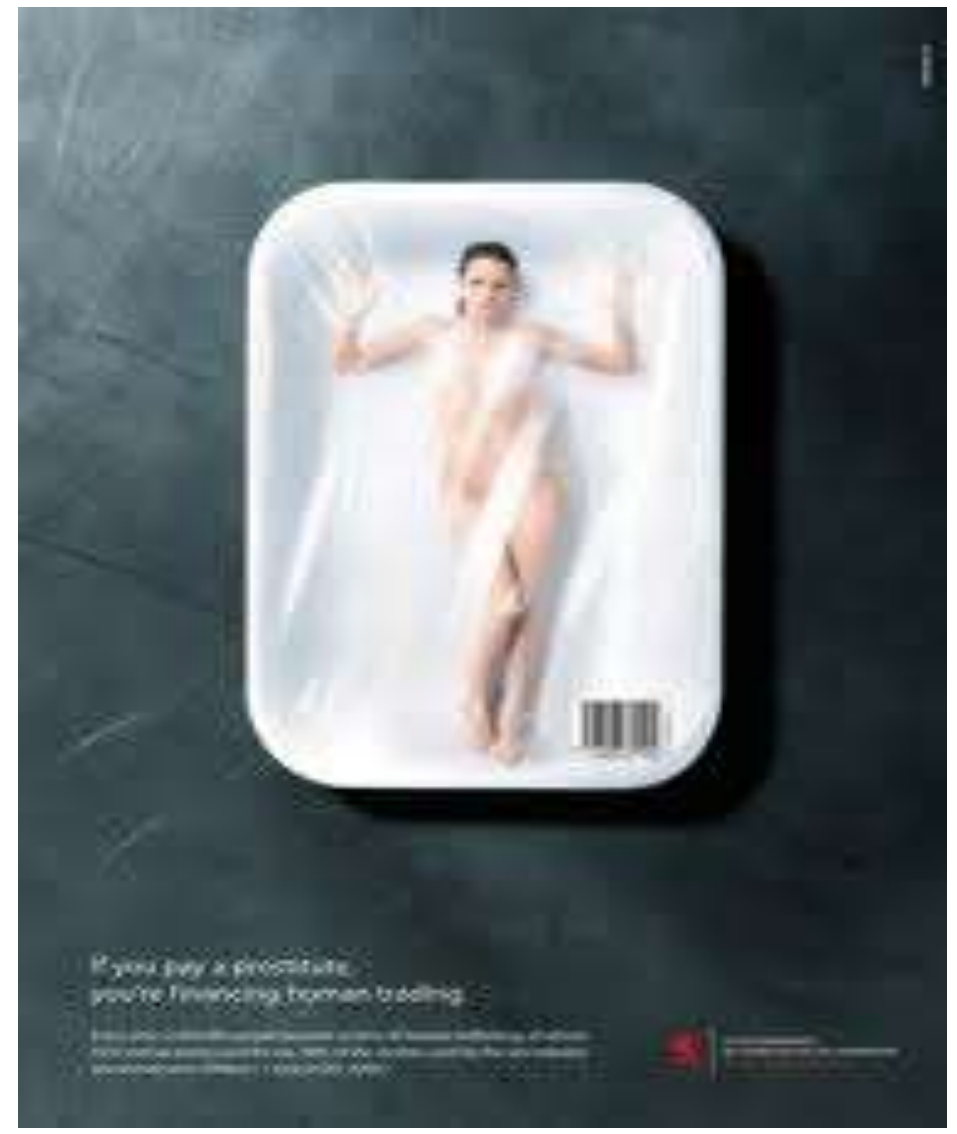

Imagem 5- Campanha vinculada em Luxemburgo em 2009.

A imagem traz uma mulher nua sendo vendida como se fosse uma mercadoria como qualquer outra, exposta numa bandeja daquelas de supermercado, onde são vendidos frios e carnes. O anúncio traz o slogan "Se você paga uma prostituta você está financiando o tráfico humano".

A bandeja sobre uma tábua de metal com cortes de faca reforça a ideia da violência do tráfico. Esta campanha remete mais diretamente ao debate das feministas abolicionistas, associando a existência do tráfico ao da prostituição; desta forma, abolindo-se a prostituição eliminar-se-ia o tráfico. Esta campanha tenta sensibilizar os consumidores do comércio do sexo, não fazendo qualquer distinção entre prostituição forçada e voluntária. Nesta imagem vincula-se o tráfico como um comércio, o que não fica claro, nas outras imagens. 


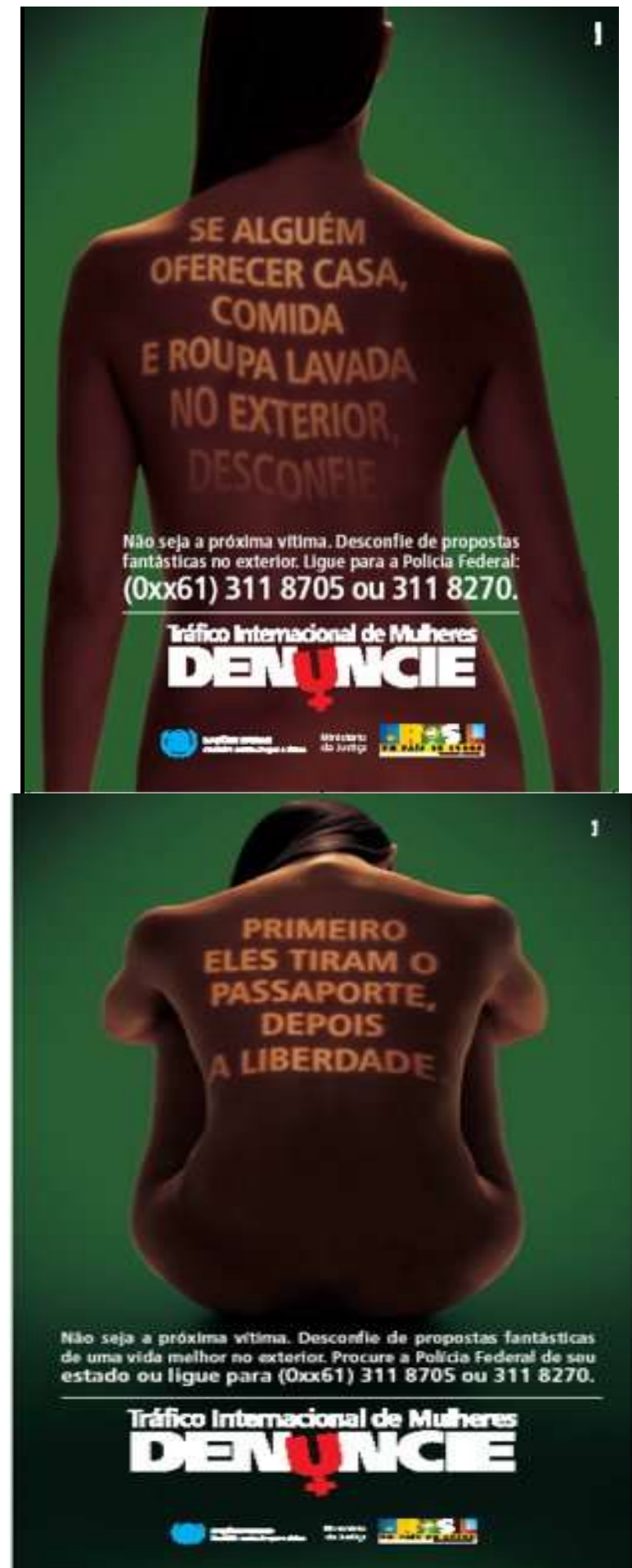

Imagem 6- Campanha vinculada no Brasil em 2004.

Esta campanha lançada em parceria entre o Ministério da Justiça e o Escritório das Nações Unidas contra Drogas e Crime (UNODC), lança o slogan "Se alguém oferecer casa comida e roupa lavada no exterior desconfie" e "Primeiro eles tiram o passaporte, depois a liberdade". Este slogan enfatiza uma 
mensagem para mulheres migrantes, principalmente das classes populares, que procuram no exterior melhores oportunidades de vida e trabalho.

A imagem da mulher nua remete à sexualidade e à prostituição. É evidente a associação da migração feminina ao tráfico de mulheres, como se qualquer ato de migrar da mulher ocasionasse em ser explorada pela prostituição. Outra mensagem passada pelo segundo slogan, é que, sem passaporte a mulher não teria alternativa, senão ceder à prostituição forçada.

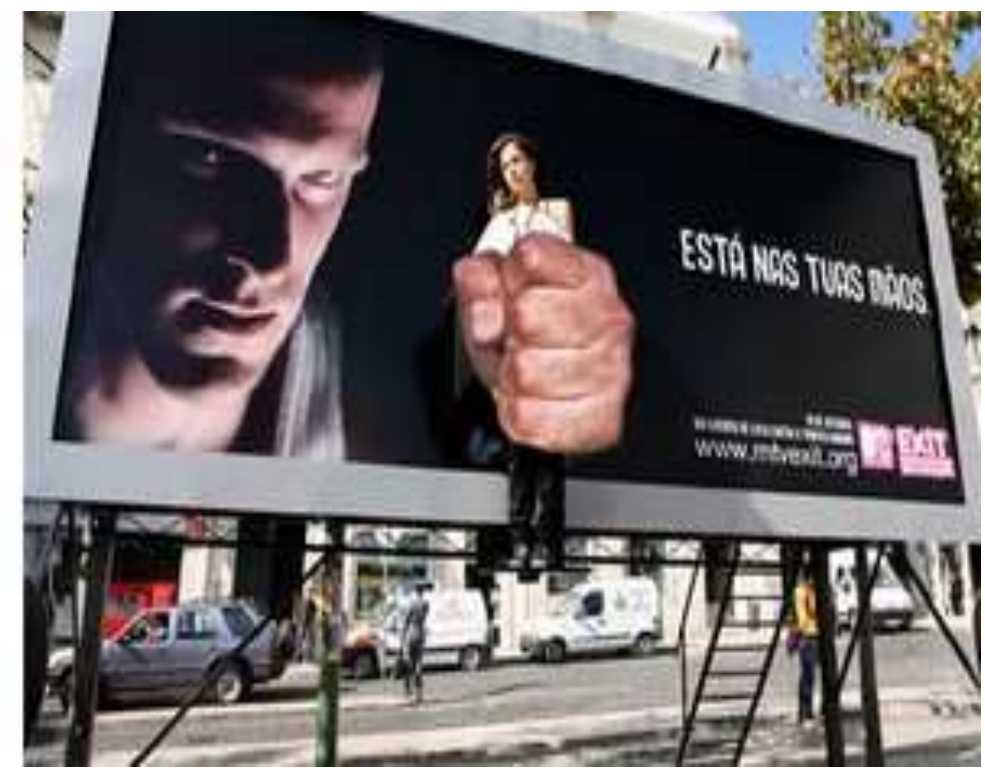

Imagem 7-Campanha vinculada em Portugal em 2007.

Esta Campanha vinculada em Portugal em 2007, no Dia Europeu da Luta Contra o Tráfico de Seres Humanos, exibe uma mulher presa pelas mãos de um homem, que aparece superdimensionado em relação ao tamanho reduzido da mulher, em demonstração de força e poder. O outdoor, não deixa explícito ser esta uma ação do tráfico de mulheres, mas da violência contra a mulher.

Nessas imagens, é recorrente a submissão, a ausência de autonomia e o aprisionamento. Em, algumas imagens aparece a figura do homem, como aliciador, detendo o poder sobre uma mulher subjugada, em outras o poder não aparece explícito, como se fosse onipresente.

A construção da imagem da mulher como objeto e mercadoria capturada pelo tráfico, marca todas as campanhas. E como tal, subtende um valor de uso, cuja finalidade tanto pode ser para o trabalho escravo ou para a prostituição forçada. E uma moeda de troca, ou seja, ela tem um preço de venda, cujo valor é fixado a partir de suas características e de acordo com o mercado consumidor. 
Os lucros obtidos neste comércio do tráfico vêm da exploração do trabalho ou dos serviços sexuais que a mulher, mediante coação, pode oferecer.

No entanto, nem sempre fica claro nas campanhas a distinção entre a prostituição forçada ou voluntária, sobressaindo a visão das feministas abolicionistas.

Neste sentido, em algumas imagens, com a de Luxemburgo em 2009, há uma associação direta entre o trafico e a prostituição, sugerindo que a existência do tráfico se deve à prostituição e que, abolindo esta, estaria eliminando o tráfico de mulheres.

Todas as campanhas vinculam a ideia de escravidão, prostituição forçada, exploração e abuso de poder sobre as mulheres, seguindo a lógica do Protocolo de Palermo (2000). Porém se restringindo apenas ao tráfico de mulheres para fins de exploração sexual, deixando de fora outras finalidades do tráfico, como para o trabalho escravo e a remoção de órgãos.

As imagens reproduzem a condição de gênero que posiciona a mulher como ser passivo, indefeso, dependente e que deve ser protegida pela a sociedade.

O foco na mulher e em sua sexualidade, informa a influência de correntes do feminismo internacional ,e, principalmente, em sua vertente abolicionista.

Vários autores criticam a representação de pessoas traficadas na forma desses retratos típicos, como modelos ou perfis de pessoas traficadas. Geralmente são mulheres representadas como objetos passivos, sem vontades próprias, expostas à violência masculina ${ }^{36}$.

Alguns estudos, notícias e reportagens constroem uma narrativa contemporânea sobre o tema que, por um lado pode ser considerada relevante para chamar a atenção pública para o problema, mas por outro lado constitui uma forma de discurso simplista que distancia da complexidade que envolve as situações de tráfico de pessoas, independente de sua finalidade.

A forma mais usual de abordar esse problema é mostrando, nas imagens das campanhas, que expõem uma representação do sofrimento da vítima, criando um laço de sentimento da pessoa que observa com as possíveis vítimas desse crime.

Como puderam observar nesse item, imagens e slogans, são peças importantes na construção, veiculação e fixação de concepções sobre o tráfico,

\footnotetext{
${ }^{36}$ Cf. Piscitelli (2004), Kempadoo (2005) e Grupo Da Vida (2005)
} 
que apesar de representarem interesses de alguns grupos, são apresentados como "verdades" para o conjunto da sociedade. 


\section{4}

\section{Tráfico no Contexto da Migração Feminina}

Nas últimas décadas do século $X X$, o fluxo migratório intensificou-se em todo o mundo, sendo caracterizado principalmente pelo deslocamento de pessoas dos países periféricos ou tidos como de Terceiro Mundo para aqueles de economia central, de Primeiro Mundo.

Apesar das mulheres sempre estarem presentes nos processos migratórios, foram tradicionalmente desconsideradas e historicamente subestimadas como sujeito social relevante pelos estudos migratórios, sendo em geral vistas como participantes passivas nos projetos migratórios tidos como masculinos.

Entretanto, nos últimos anos, assistimos a um expressivo crescimento e visibilidade de mulheres nos fluxos migratórios, fenômeno este conhecido como feminização das migrações, que chama atenção não só pelos dados quantitativos, mas pela descoberta da importância das mulheres nestes processos.

Nesse capítulo, procurou-se analisar as especificidades da migração feminina, num contexto de significativas mudanças econômicas e políticas ocorridas em nível mundial, que terão implicações nas condições de vida e de trabalho das populações.

A articulação das temáticas de gênero, migração e tráfico, trouxe uma maior compreensão sobre os mecanismos que colocam as mulheres como um "grupo vulnerável" no processo migratório e objeto de tutela pelos países de destino e de origem, principalmente quando originadas de países de Terceiro Mundo, em situação irregular ou inseridas na indústria do sexo, apontando para a necessidade de se repensar a questão migratória também a partir da dimensão de gênero. 


\section{1 \\ A feminização das migrações}

A crise econômica mundial do final dos anos de 1970 e início dos 80, impôs um novo padrão de acumulação, uma nova etapa de expansão capitalista, marcada por uma revolução tecnológica e organizacional da produção, com a flexibilização dos processos e das relações de trabalho.

Tais mudanças são acompanhadas pela tendência à redução do Estado no seu papel regulador da economia e de proteção social, pela desregulamentação dos mercados comerciais e financeiros, privatizações de empresas públicas, e, pelo sucateamento das políticas sociais públicas, marcando um processo diferenciado daquele vivido no pós II Guerra, por países de economia central.

A criação de riqueza ao longo do século $X X$ foi sujeita a uma série de regulamentações públicas, estatais e não estatais consequentes das lutas operárias pelo direito ao trabalho e à proteção no século anterior, o que tornou possível alguma redistribuição de riqueza e a criação de condições de segurança a populações que não eram as detentoras da riqueza. Os direitos sociais e os direitos econômicos, como: o subsídio de desemprego, a saúde pública, a educação, o seguro social, etc, foram medidas de redistribuição social fundamentais na criação de uma rede que mitigasse o risco social, evitando que as pessoas mergulhassem na pobreza abrupta ${ }^{37}$.

O desmantelamento gradativo, a partir dos anos 80 , desses sistemas públicos de proteção social, característicos dos chamados Welfare State, vem implicando em diversos países, em formas de desregulamentação dos direitos e no corte em gastos sociais, deixando milhões de pessoas à própria sorte e "mérito individual", contribuindo para o aumento da insegurança em relação à sobrevivência de milhões de pessoas em todo o mundo.

As consequências deste processo para homens e mulheres trabalhadores são sentidas pelo aumento do desemprego, destruição de postos de trabalho não qualificados, redução dos salários devido ao aumento da oferta de mão - de- obra e redução de gastos com as políticas sociais, tornando-as cada vez mais restritivas, seletivas e focalizadas na extrema pobreza.

\footnotetext{
${ }^{37}$ Cf. SANTOS, Boaventura et al, 2009,p.4.
} 
No entanto, de acordo com Helena Hirata (2001), os efeitos foram diferentes para o trabalho de homens e mulheres,

Os efeitos da globalização, complexos e contraditórios, afetaram desigualmente o emprego masculino e feminino nos anos 90 . Se o emprego masculino regrediu ou estagnou, a liberalização do comércio e a intensificação da concorrência internacional tiveram por consequência um aumento do emprego e do trabalho remunerado de mulheres ao nível mundial, com exceção da África subsaariana (...). Contudo, essa participação se traduz principalmente em empregos precários e vulneráveis (p.143).

O paradoxo desse processo, apontado por Hirata (2001), foi o aumento do emprego e do trabalho remunerado das mulheres em nível mundial, tantos nas áreas formais e informais, assim como no setor de serviços. Porém esta participação das mulheres no mercado de trabalho se traduziu pela precarização e vulnerabilidade crescentes.

Em suma, a quebra das estruturas tradicionais de trabalho, a predileção pela força de trabalho feminina na indústria e em diversas áreas da produção, com a consequente queda das novas oportunidades de trabalho masculino, e o efeito generalizado de ocidentalização de tais contextos formam o quadro de rupturas que dá margem à emigração internacional (Sassen, 1988).

Ruth Pearson (1995) ressalta que, esta mudança global representou por um lado, novas oportunidades, e por outro, apresentou também novos riscos para as mulheres trabalhadoras. As desigualdades sociais nas relações de trabalho e saúde parecem, segundo a autora, ter piorado sob o impacto das políticas de flexibilização.

Porém a tendência é que este modelo se generalize por toda a população ativa, configurando a situação de crise do paradigma do emprego estável e protegido (Hirata, 2001).

O trabalho precário, vulnerável e flexível, seria uma forma de desmantelar as normas de emprego predominantes até então. E neste contexto as mulheres seriam menos protegidas pela legislação do trabalho e pelas organizações sindicais.

Segundo estudo da Organização Internacional do Trabalho (OIT, 2012), cerca de três em cada mil pessoas em todo o mundo são vítimas de trabalho forçado. O número total de pessoas presas em empregos que lhes foram impostos por meio de coação ou de engano chega a 20,9 milhões. Nessas situações também podem ser incluídos o tráfico de seres humanos ou práticas análogas à escravidão. 
De acordo com o levantamento, mulheres e meninas representam 11,4 milhões (55\%) do total de trabalhadores forçados, enquanto homens e meninos representam 9,5 milhões (45\%).

\section{Gráfico 1- Pessoas em situação de trabalho forçado no mundo por sexo (milhões)}

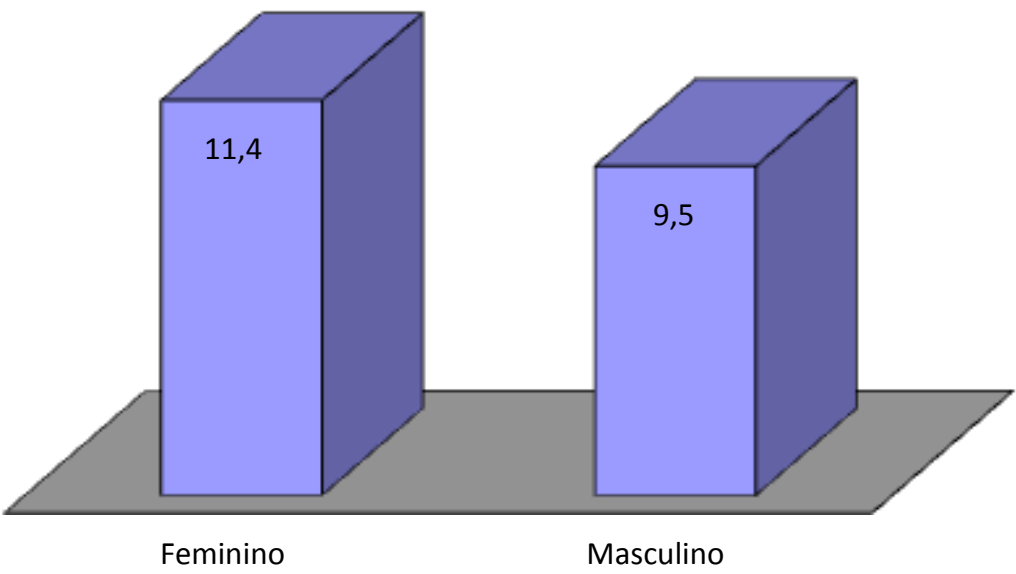

Fonte: Organização Internacional do Trabalho - OIT 2012.

Além disso, os adultos são mais afetados do que as crianças, pois $74 \%$ (15,4 milhões) das vítimas são maiores de 18 anos e 26\% (5,5 milhões) estão abaixo dessa faixa etária.

A região da Ásia e do Pacífico apresenta o número mais alto de trabalhadores forçados no mundo, 11,7 milhões (56\%). A África vem em seguida, com 3,7 milhões (18\%), e a América Latina, com 1,8 milhão de vítimas (9\%). Nos países da Europa Central e do Leste Europeu são registrados 1,6 milhão (7\%) de pessoas trabalhando de forma forçada. Nas economias desenvolvidas e na União Europeia há 1,5 milhão $(7 \%)$ de trabalhadores forçados, enquanto no Oriente Médio, o número de vítimas é estimado em 600 mil (3\%) (OIT, 2012). 


\section{Gráfico 2- Porcentagem de trabalhadores forçados no mundo (milhões)}

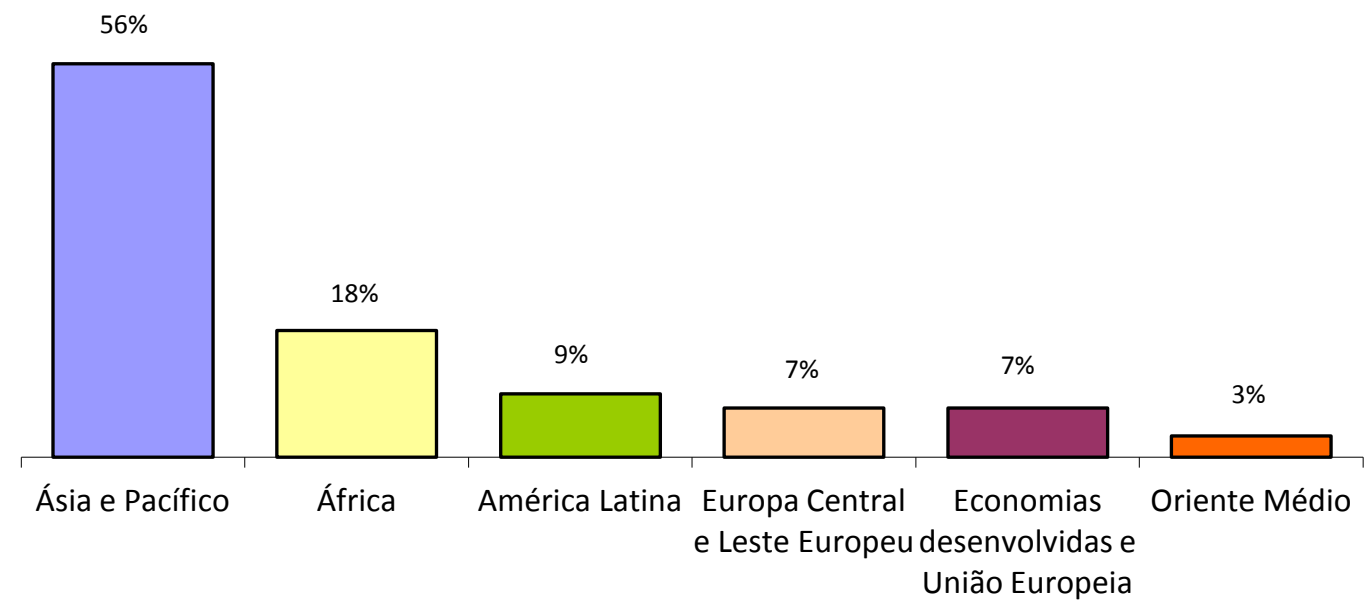

Fonte: Organização Internacional do Trabalho - OIT 2012.

O estudo mostra ainda que $90 \%$ dos trabalhadores (18,7 milhões) são explorados na economia privada, por indivíduos ou empresas. Desses, 4,5 milhões (22\%) são vítimas de exploração sexual forçada e 14,2 milhões (68\%) são forçados em atividades econômicas como agricultura, construção civil, trabalho doméstico ou industrial (OIT, 2012).

Gráfico 3- Principais atividades exploradas no mundo na economia privada, por indivíduos ou empresas (milhões)

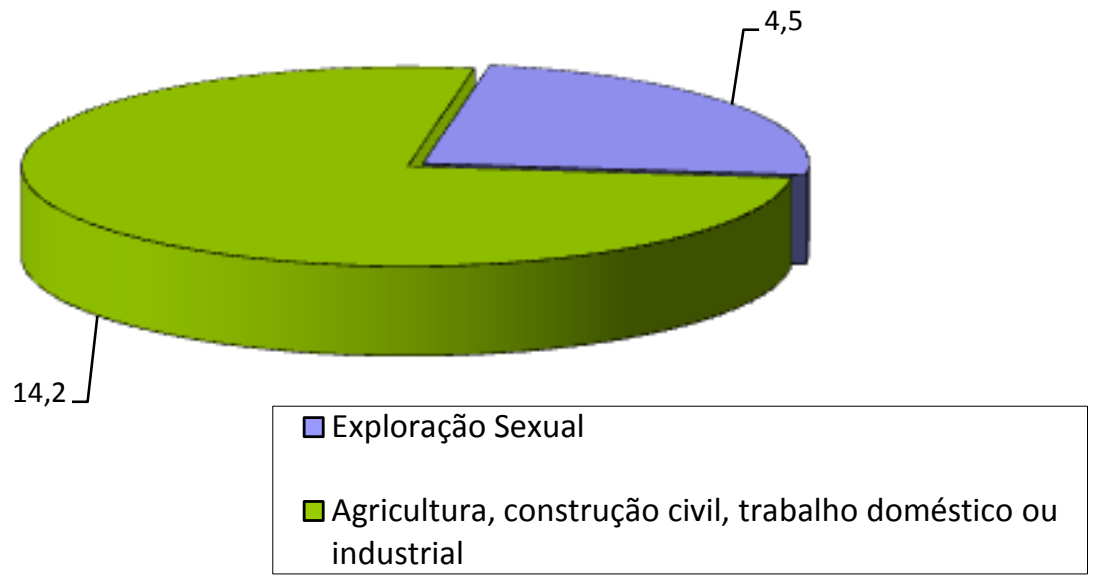

Fonte: Organização Internacional do Trabalho - OIT 2012. 
Além disso, 2,2 milhões (10\%) são vítimas de trabalho forçado imposto pelo Estado, como por exemplo, nas prisões, o que viola as normas da OIT, ou imposto por forças armadas rebeldes ou exércitos nacionais.

\section{Gráfico 4- Principais exploradores do trabalho forçado no mundo (milhões)}

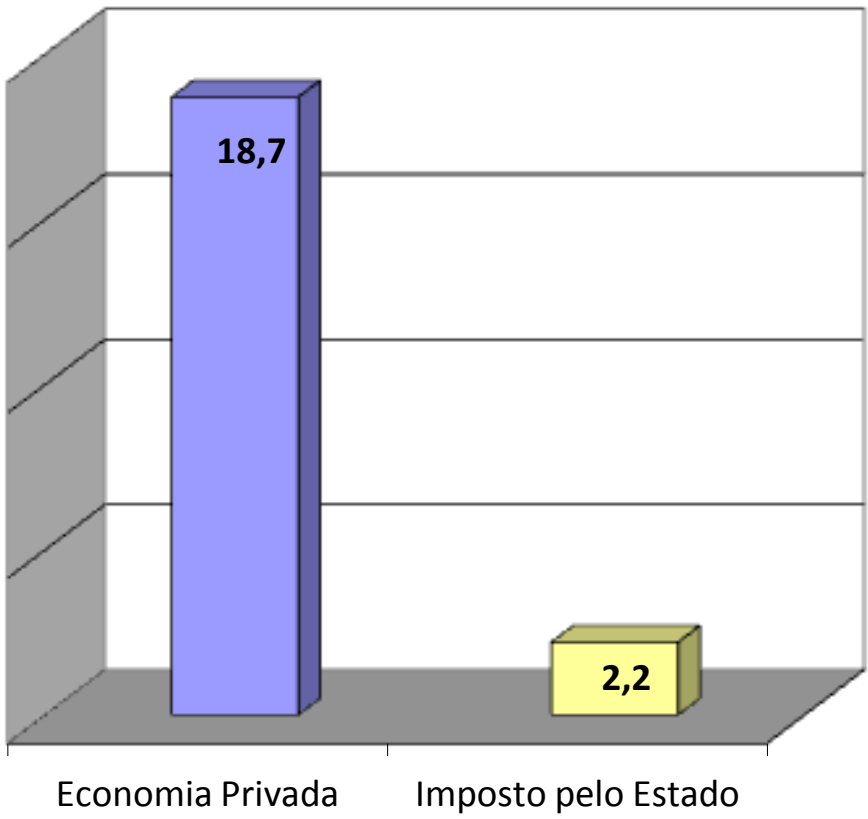

Fonte: Organização Internacional do Trabalho - OIT 2012.

A maioria dessas pessoas, 11,8 milhões (56\%), está submetida a trabalho forçado em seus países de origem ou residência.

O documento da OIT (2012) também apresenta a relação entre migração e trabalho forçado. Há 9,1 milhões de vítimas (44\%) que estão presas no trabalho forçado após um processo migratório, ou seja, o deslocamento dentro de seus países ou para o exterior.

As condições de trabalho precário e às vezes em condições subhumanas encontradas no país de origem, conforme os dados acima, estimularão a emigração de pessoas à procura de novas oportunidades além das fronteiras, numa expectativa de mudar suas condições de vida e trabalho.

Com as novas tecnologias de informação e comunicação, aumentam os fluxos de informação a respeito das oportunidades ou dos padrões de vida existentes ou imaginados nos países de Primeiro Mundo, suscitando o desejo 
cada vez maior de migrar e de aproveitar as oportunidades que se apresentam (Martine, 2005).

Assim os padrões de migração vão refletir as desigualdades entre países que no contexto atual, serão acentuadas pelas mudanças econômicas e sociais estimuladas pelos novos processos produtivos.

A ausência de perspectiva de melhores condições de vida e trabalho em seus países de origem, vem levando homens e mulheres a deixarem seus países, intensificando os fluxos migratórios.

Entretanto, pessoas não só migram por motivos econômicos e sociais que geram o desejo de buscar melhores oportunidades de vida e de trabalho em outros locais. Apesar de ser este um grande estímulo, migram também pela existência de conflitos armados, por perseguições políticas, mudanças ambientais, formação ou reunificação familiar, o desejo de conhecer o mundo, entre outros.

Para Adriana Piscitelli (2006), deve-se considerar a migração como um projeto de mobilidade social (familiares e individuais), trazendo outros fatores subjetivos como a realização de um sonho, que não se limita a expectativas econômicas.

As estatísticas sobre a migração mostram essa intensificação dos fluxos migratórios. Em 2010, estima-se que a população migrante a nível mundial tenha chegado aos 214 milhões de pessoas, ou seja, 3,1\% da população mundial.

\section{Gráfico 5- Migrações Internacionais (milhões)}

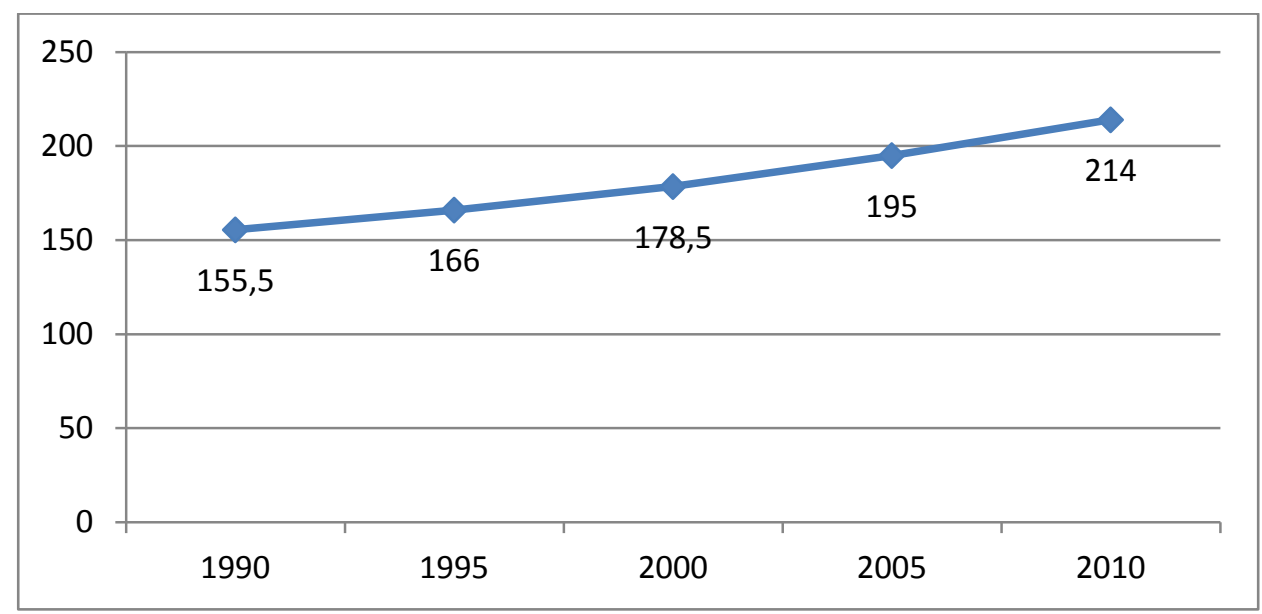

Fonte: UN - International Migrant Stock: The 2008 Revision. 
Em 2005, segundo a ONU, esta girava em torno de 195 milhões de migrantes internacionais, contra os 178,5 milhões do ano 2000. Mantendo a percentagem média de $3 \%$ da população mundial.

\section{Grafico 6- Migrantes internacionais como porcentagem da população mundial}

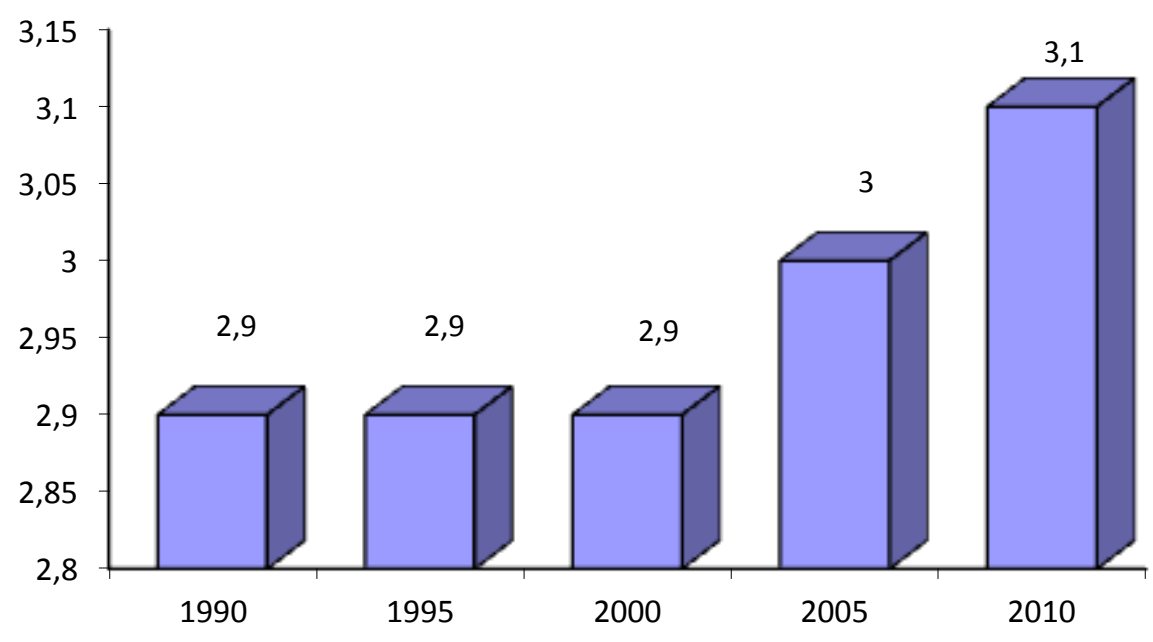

Fonte: UN - International Migrant Stock: The 2008 Revision.

Do total de migrantes, em 2010, 49\% era constituído por mulheres, o que corresponde a cerca de 104,8 milhões.

\section{Gráfico 7- Porcentagem de mulheres sobre o total de migrantes internacionais}

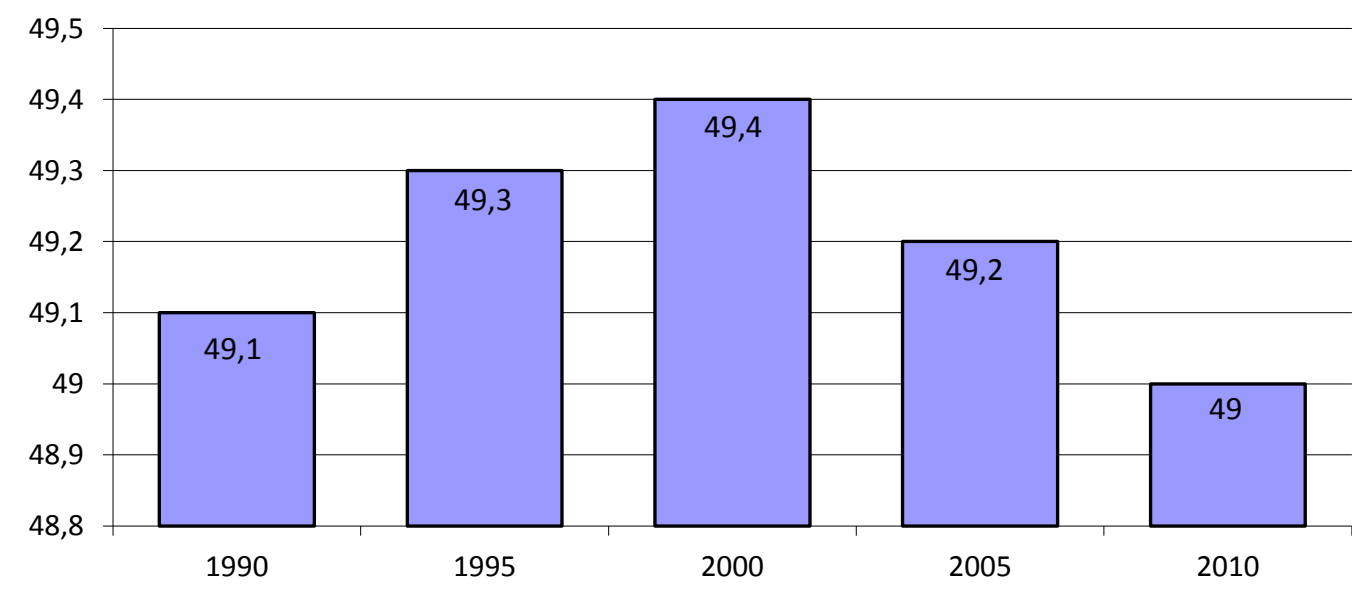

Fonte: UN - International Migrant Stock: The 2008. 
O gráfico abaixo mostra o percentual de mulheres migrantes no mundo, dividindo em regiões países menos desenvolvidos e regiões mais ou menos desenvolvidas ${ }^{38}$.

\section{Gráfico 8- Porcentagem de mulheres sobre o total de migrantes internacionais por região*}

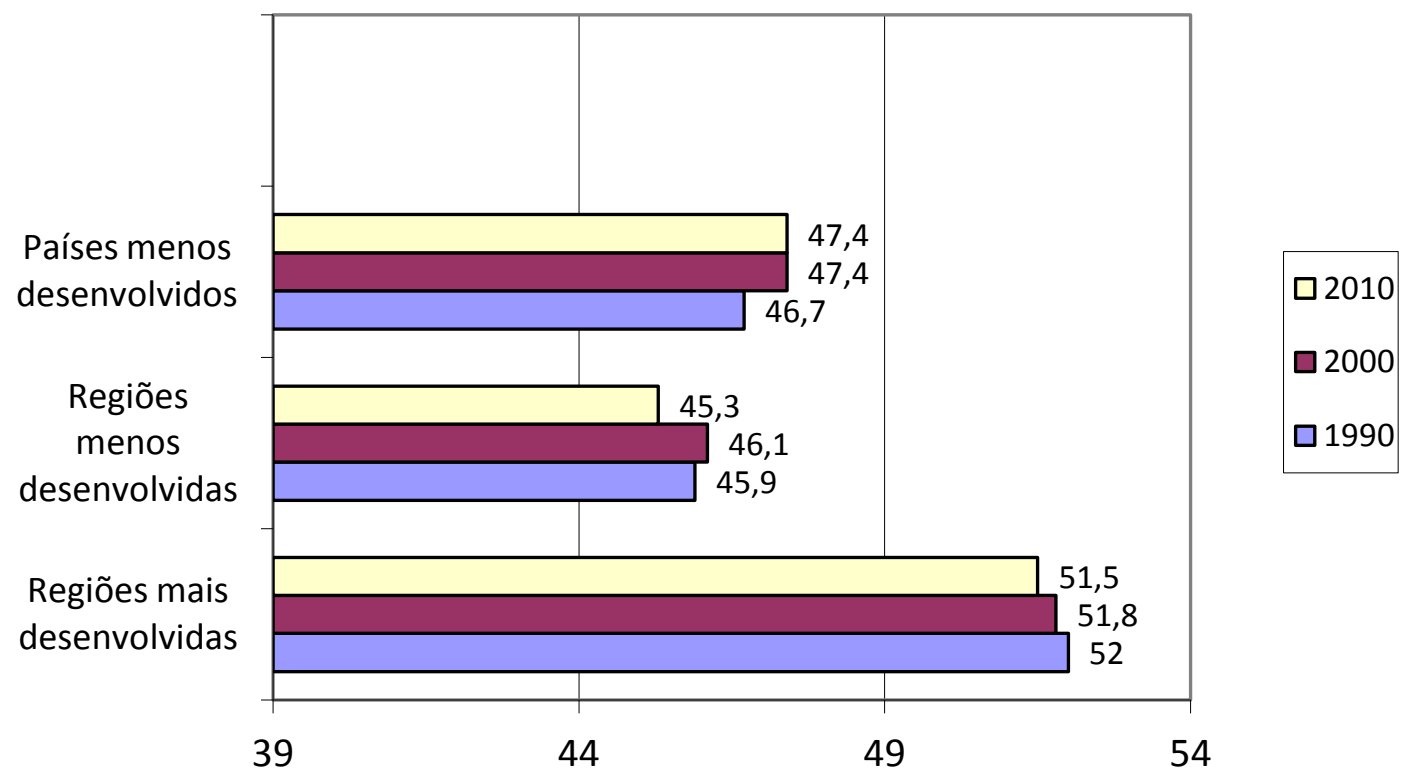

Fonte: UN - International Migrant Stock: The 2008 Revision.

A migração feminina tem suas peculiaridades, pois nem sempre pode ser equiparada à migração masculina, tanto em termos de motivações e oportunidades, quanto em termos de suas consequências.

Um exemplo sobre estas diferenciações pode-se ter com o envio de remessas.

\footnotetext{
$38 \mathrm{Na}$ classificação das Nações Unidas: Regiões mais desenvolvidas: as regiões mais desenvolvidas compreendem Austrália, Europa, Japão, Nova Zelândia e América do Norte. As regiões menos desenvolvidas: As regiões menos desenvolvidas compreendem África, Ásia (excluindo Japão), América Latina e no Caribe, Melanésia, Micronésia e Polinésia. Países menos desenvolvidos: o grupo de países menos desenvolvidos é atualmente composto por 49 países Afeganistão, Angola, Bangladesh, Benin, Butão, Burkina Faso, Burundi, Camboja, República Central Africano, Chade, Comores, República Democrática do Congo, Djibuti, Guiné Equatorial, Eritreia, Etiópia, Gâmbia, Guiné, Guiné-Bissau, Haiti, Quiribati, República Democrática Popular do Laos, Lesoto, Libéria, Madagáscar, Malawi, Maldivas, Mali, Mauritânia, Moçambique, Mianmar, Nepal, Níger, Ruanda, Samoa, São Tomé e Príncipe, Senegal, Serra Leoa, Ilhas Salomão, Lêmen, Zâmbia. Esses países também estão incluídas nas regiões menos desenvolvidas: Somália, Sudão, Timor-Leste, Togo, Tuvalu, Uganda, República Unida da Tanzânia, Vanuatu.
} 
De acordo com o Fundo das Nações Unidas para Populações mulheres não só são mais constantes no envio de remessas, como também enviam uma parte maior de seus salários:

Sabe-se que as mulheres são mais consistentes nos envios de remessas para os seus países, assim como no envio de quantias maiores dos seus salários. Tendo como ponto de partida o fato das mulheres serem agentes e transmissores de cultura, tudo indica que o seu papel nas transferências de remessas é maior que o dos homens (UNFPA - United Nations Population Fund "Situação da População Mundial 2006 - Passagem para Esperança: Mulheres e Migrações Internacionais").

Para Ratha (2007), uma das dimensões mais concretas da migração transnacional são as remessas financeiras dos migrantes para seus países de origem. Elas contribuem para o aumento do poder de compra das famílias dos migrantes e têm um efeito em cadeia para toda a comunidade envolvida. Para se ter uma real noção do significado dessas remessas para os países receptores, convém identificar a sua participação no produto interno bruto (PIB). Conforme mostram dados do Banco Mundial para o ano de 2006, as remessas significaram $36 \%$ do PIB da Moldávia, $26 \%$ do de Honduras, $24 \%$ do da Guiana e $15 \%$ do da Albânia ${ }^{39}$.

Esses percentuais revelam uma grande dependência desses países em relação às remessas, exercendo um impacto decisivo sobre sua balança de pagamento e tornando-os bastante sensíveis à conjuntura econômica mundial. Sabemos também que as remessas de migrantes superam todo o orçamento dos fundos de ajuda ao desenvolvimento, financiado pelos países industrializados (Ratha, 2007)

Segundo dados do Banco Interamericano de Desenvolvimento (BID), as remessas financeiras dos emigrantes latino-americanos para seus países de origem têm crescido anualmente e as mulheres aparecem como as que têm maior participação no envio de remessas para seus países de origem, na ajuda de parentes e para acumular recursos para o retorno ao país em melhores condições de vida.

Assim, a participação fiel das mulheres no envio de remessas ao seu país de destino, para seus filhos e familiares, ajudará posteriormente a entender o maior controle sobre as mulheres em deslocamento.

\footnotetext{
${ }^{39}$ Ver a esse respeito http://siteresources.worldbank.org/INTPROSPECTS/Resources/3349341199807908806/Top10.pdf
} 
A feminização das migrações chama a atenção não apenas pelos dados quantitativos, mas pela crescente importância e autonomia das mulheres nos processos migratórios. Apesar de sua inserção laboral e familiar nos países de destino continua por reproduzir em sua maioria relações de subordinação e submissão.

As mulheres despejaram-se em mercados de trabalho ao redor do globo; o efeito foi cortar na raiz de uma vez por todas o ideal de salário familiar do capitalismo organizado pelo Estado. No capitalismo neoliberal "desorganizado", este ideal foi substituído pela norma da família de dois assalariados. Não importa que a realidade que subjaz o novo ideal sejam os níveis salariais decrescidos, diminuição da segurança no emprego, padrões de vida em declínio, um aumento abrupto no número de horas trabalhadas em troca de salários por família, exacerbação do turno dobrado- agora frequentemente triplo ou quádruplo- e um aumento de lares chefiados por mulheres (Fraser, 2009, p.25).

É importante constatar que essas estimativas não contabilizam o número de migrantes irregulares, cuja quantidade é impossível estabelecer com precisão. Esta é uma outra característica marcante da realidade migratória, o forte aumento da migração irregular.

Martine (2005) afirma que,

A globalização tem grande impacto sobre os movimentos migratórios, mas de "forma segmentada e contraditória", ou seja, "leva ao desenraizamento quando acelera o progresso econômico que transforma comunidades, estimula as pessoas a abandonar trabalhos tradicionais e buscar novos lugares". Entretanto, "há o paradoxo da estabilização e até retração dos fluxos de migração internacional, pois 'o Mundo sem Fronteiras' é parte da definição da globalização, mas não se aplica ao movimento de pessoas"(p.8).

Com efeito, as políticas migratórias cada vez mais seletivas a partir dos anos 80 , levam a maioria dos migrantes a valer-se de caminhos de ingresso irregular, que envolve ações de contrabando de migrantes (smuggling) ou de tráfico de pessoas. Atualmente, estima-se em cerca de 30/40 milhões o número de migrantes em situação irregular.

É importante constatar que essas cifras geralmente não contabilizam o número de migrantes "não-autorizados", "ilegais" ou "não-documentados", cuja quantidade é impossível estabelecer com precisão (...). A Organização Internacional para as Migrações sugere que o número dos migrantes não-oficiais poderia ascender a uns 33 milhões. Entretanto, no caso dos Estados Unidos, o Bureau do Censo calcula que pelo menos $30 \%$ dos seus 30 milhões de migrantes em 2000 eram ilegais. Mantida essa relação entre "migrantes oficiais" e "migrantes não-documentados", na realidade, alcançaria 52 milhões. Tomando 
em consideração a rigidez e a complexidade do aparato repressivo nos Estados Unidos, em comparação com os controles migratórios menos rigorosos em outras partes do mundo, é até possível que esse número seja ainda maior. (Martine, 2005, p.8)

A reestruturação do mundo do trabalho e diminuição do papel do Estado implementadas em diversos países capitalistas, fez recair sobre esta mulher migrante a precariedade das condições de trabalho, o que dificulta a integração e inserção destas nas sociedades de destino, ainda mais se tiver em situação irregular.

De acordo com Lutz (apud Lisboa, 2007):

(...)aproximadamente 10 milhões de mulheres no mundo não possuem cidadania nos atuais países em que vivem; destas, 1 milhão são trabalhadoras domésticas e dependem da "bondade" de seus patrões para continuar sobrevivendo no país para o qual migram. Quase 20 milhões de mulheres no mundo vivem em condições de "segunda categoria", lutando por sobrevivência e para ter seus direitos garantidos ( $\mathrm{p} .811)$.

Historicamente, a presença da mulher no âmbito da migração, estava ligada, predominantemente à chamada reunificação familiar. No entanto, nos últimos anos, aumentou muito o número de mulheres que se deslocam sozinhas com o propósito migratório laboral.

$\mathrm{Na}$ origem dessa mudança está o aumento da demanda de mão-de-obra feminina para tarefas domésticas (faxineiras, babás, atenção a idosos e doentes, cozinheiras etc. $)^{40}$. Além da demanda no comércio e serviços (garçonete, dançarina, modelo, balconista de supermercado, atendente de loja de roupas, etc.), bem como no mercado do sexo, atendendo a demanda do mercado informal nos países desenvolvidos como alternativa de geração de renda.

Os serviços domésticos, em específico, comumente exigem mão de obra extremamente flexível, inclusive quanto a horários e tipo de atividades, o que dificulta a integração da migrante na sociedade de chegada, além de tornar mais complexa a reunificação familiar e a autonomia pessoal.

Esse trabalho doméstico precarizado, feito geralmente por mulheres migrantes, é que permite, por outro lado o crescimento e uma maior independência de uma minoria significativa de mulheres em profissões executivas e intelectuais (Hirata, 2001)

\footnotetext{
${ }^{40}$ Cf. Marinucci e Milesi.
} 
Sobre esta dualidade, os estudos de Rachel Parrenãs (2002) ilustram que, o atual processo de globalização reforça as relações de desigualdades entre as mulheres, sendo que o reconhecimento de determinados direitos por parte de alguns grupos ocorre em detrimento dos direitos de outro:

(...) para livrar-se do peso do trabalho doméstico, as mulheres [nativas] dependem da comercialização deste trabalho e compram os serviços das mulheres mais pobres e a baixo preço. E em nossa sociedade globalizada, são as trabalhadoras migrantes do Sul que estão liberando cada vez mais as mulheres do Norte desse peso. Todavia, isso traz consequências negativas para a relação entre mulheres. $O$ progresso de um grupo de mulheres dá-se à custa da desvantagem de outro grupo de mulheres, porque, no processo de livrar outras mulheres desse peso, às trabalhadoras migrantes do Sul comumente é negado o direito de cuidar da sua própria família (p.29).

Como consequência desta dualidade, as mulheres migrantes que desenvolvem estes trabalhos domésticos precisam contar com uma rede de parentes e amigos, para o cuidado com seus filhos, seja no país de destino ou no país de origem.

Patrícia Castellanos (2005), em sua análise sobre o trabalho doméstico no Chile, reconhece que,

La separación de las familias, la responsabilidad económica de la mujer migrante respecto a su familia en la país de origen y la delegación del cuidado de los hijos, ha gerado un nuevo tipo de hogar familiar de carácter transnacional. Esta familia sigue cohesionada alrededor de los acuerdos establecidos por sus miembros, pero ahora funciona sin que la madre esté presente en la cotidianeidad de la crianza de sus hijos (p.47).

Para Massey et al. (1987), as condições que dão origem à migração podem ser totalmente diferentes das condições que a perpetuam no tempo. Se transformações estruturais nas sociedades de origem e de destino respondem pelo início dos fluxos migratórios internacionais, as redes sociais conferem a tais fluxos estabilidade, transformando-os em movimento de massa.

As redes de apoio são determinantes não só na decisão de migrar, mas também na inserção da pessoa migrante no país de destino.

As redes sociais mais importantes fundam-se em relações de parentesco, de amizade, de trabalho e na origem comum. Essas relações não são criadas pelo processo migratório, mas são adaptadas por ele e, no decorrer do tempo, são reforçadas pela experiência comum da migração. Assim, "a migração pode ser entendida como processo social, organizado por meio de redes forjadas por 
conexões interpessoais diárias, que caracterizam todos os grupos humanos" (Massey et al., 1987, p. 169).

Em relação à inserção de mulheres migrantes no mercado do sexo, esta se dá, tanto como uma continuidade da atividade desenvolvida pela mulher no país de origem, procurando no exterior melhor mercado consumidor e ganhos ou, por uma inserção temporária, como estratégia de sobrevivência quando de sua chegada ao país de destino ou ainda, por meio de engano e falsas promessas de trabalho para a exploração sexual e prostituição forçada; neste caso se constitui em tráfico.

Com as dificuldades de ingressarem em outros países, muitas dessas imigrantes entram de forma irregular com a ajuda de "intermediários". E nessas condições, ao chegarem ao destino, se inserem em setores informais da economia, com pouca ou nenhuma proteção de direitos, dentre os quais a prostituição. Esta atividade aparece como uma alternativa para as mulheres migrantes de pouca qualificação, que muitas vezes de forma voluntária, veem neste setor a possibilidade de fácil inserção e onde há perspectivas de lucratividade rápida.

Assim como o setor de trabalho e serviços domésticos, o mercado do sexo também é marcado por uma maior desregulação, preconceito e precarização, quando comparados com os demais setores. E são setores em que a maioria é de mulheres.

Para Vasconcelos e Bolzon (2008), em relação à precarização do trabalho doméstico e do trabalho sexual, observam que estes cenários, a princípio podem proporcionar maior espaço para situações de abuso, exploração e violência.

Assim, em lugar de definir a própria prostituição como uma violência inerente contra as mulheres, são as condições de vida e de trabalho em que as mulheres podem se encontrar no trabalho do sexo, e a violência e terror que cercam esse trabalho num setor informal ou subterrâneo que são tidos como violadores dos direitos das mulheres e, por tanto considerados como tráfico (Kempadoo, 2005: p.62).

As atividades que referem a indústria do sexo não dizem respeito somente à prostituição, envolvem também serviços de entretenimento sexual, como dançarinas, strip-teases, shows de sexo ao vivo, serviços de tele-sexo, entre vários outros (Anderson \& Davidson, 2004). 
Em relação, especificamente, à prostituição, há diferentes posicionamentos entre os diversos países, que vão desde a sua criminalização até algumas formas de legalização. Porém na maioria dos países o mercado do sexo se mantém à margem de qualquer possibilidade de reconhecimento como um tipo de trabalho, o que, sem a proteção legal ou do Estado, tende a uma maior precarização e risco de exploração.

\begin{abstract}
É imperativo notar que os defensores dos direitos dos trabalhadores sexuais admitem que o trabalho sexual é um trabalho duro e que as condições na indústria do sexo variam de relativamente boas até extremamente exploradoras e abusivas, esta última frequentemente facilitada pela exclusão dos (imigrantes) trabalhadores sexuais de direitos e proteção legal garantidos a outros como cidadãos e trabalhadores. Consequentemente, eles devem procurar corrigir esses abusos melhorando as condições de trabalho e dando reconhecimento legal para a indústria do sexo, em contraste com as "abolicionistas" que procuram tornar a indústria do sexo mais ilegal do que normalmente é e perseguir e punir homens envolvidos como clientes e outros (Ditmore \& Wijers, 2003, p.82).
\end{abstract}

Entretanto, não há um consenso em relação à concepção do grupo que defende os direitos das trabalhadoras sexuais, como se viu no capítulo anterior. O grupo das feministas abolicionistas, que vem ganhando espaço pela aproximação com segmentos conservadores e religiosos, concebe a prostituição, independente de ser voluntária ou não, como uma violência contra a mulher. $E$ entendem que o tráfico ocorre porque existe prostituição.

A associação do tráfico de pessoas com a prostituição vem sendo utilizada como argumento em diversos países para impedir ou estigmatizar o fluxo migratório de mulheres, principalmente se essas não tiverem qualificação e recursos para se manterem no país de destino e, se forem suspeitas de atravessar as fronteiras para se inserir na indústria do sexo.

O fato de serem escassas outras oportunidades de migração e de o negócio do sexo constituir um "nicho" atrativo para estrangeiros em situação irregular (a prostituição é habitualmente uma forma não regulada e informal de atividade econômica) pode estar na base de muitos fluxos.

Há ainda de se evitar a generalização que banaliza e reduz principalmente toda e qualquer mulher em mobilidade à condição de vítima do tráfico, sem contudo realmente serem.

Piscitelli (2004) destaca que esta associação é utilizada como meio de controle da mobilidade, 
Ao unir-se aos discursos internacionais hegemônicos sobre o tráfico, apagando a complexidade que permeia a migração de brasileiras no marco da transnacionalização do mercado sexual, certas tendências presentes no debate brasileiro oferecem, a partir de um contexto de "Terceiro Mundo", elementos que favorecem o controle do trabalho migrante. De maneira mais específica, tomando emprestadas as palavras de Kamala Kempadoo (2003), essas abordagens oferecem elementos que contribuem para um maior policiamento, o controle da mobilidade, dos corpos e da sexualidade das mulheres do Sul (p.313-314).

É sabido, que a prostituição é uma das atividades em que ocorre a exploração de pessoas pelo tráfico, especialmente mulheres, porém, que não é a única: há outras atividades de trabalho, que podem ocorrer o tráfico, conforme a definição contida no Protocolo de Palermo.

Além disto, a maior restrição das fronteiras favorece o crescimento de situações de violação de direitos humanos, como ao próprio tráfico, visto que o migrante não terá alternativa de deslocamento, senão pela migração irregular.

Neste "quebra-cabeça", onde diversos interesses, estão em jogo, há de se considerar também, que a presença de migrantes irregulares "exploráveis" e sem nenhum direito, é tolerada quando serve para preencher os vazios do mercado de trabalho, sendo funcional ao crescimento das economias.

Como se pode ver, a ampliação da presença da mulher migrante em diversos setores laborais nos países de destino, ainda que em sua maioria em setores precários e informais, no preenchimento de espaços que mulheres nacionais não querem ocupar, aumenta a sua importância, inclusive no envio de remessas para seu país de origem, mas também a coloca sob maior vigilância e controle.

\section{2 \\ Tráfico e Contrabando}

O tráfico de pessoas ocorre no contexto da migração, mas não deve se confundir com a migração em si. Trata-se de uma violação de direitos humanos no processo de deslocamento no qual alguém migra com o auxílio de um terceiro, que pode ser uma pessoa ou um grupo, que usa de engano ou coação para convencê-lo a migrar, frequentemente com promessas de trabalho no local 
de destino, onde essa terceira parte submete à exploração aquele que se desloca.

Geralmente a pessoa traficada migra de forma legal ou regular, mas se torna irregular em face da retenção de seus documentos pelos exploradores como meio de subjugá-la a realizar a atividade que lhe é imposta. Assim, são tratadas pelos governos dos Estados como migrantes irregulares, detidas e deportadas, e não, como pessoas que estão sofrendo graves violações aos seus direitos humanos.

\begin{abstract}
Mencionar "crime organizado" no lugar de "imigração ilegal" é uma fórmula ainda mais potente e populista. Medos e preconceitos em relação à "imigração ilegal" estão dando novas bases (a questão não é apenas que a sociedade será "invadida" por "alienígenas", mas também surpreendida por "máfia" e outros criminosos perigosos), e as repressões às migrações irregulares são justificadas e humanizadas (capturando, detendo e deportando migrantes sem documentação mudam de significado quando apresentados como resgatando, reabilitando e reinserindo as vítimas do crime organizado) (Anderson \& Davidson, 2004, p.14).
\end{abstract}

A associação do tráfico a migração irregular por parte de muitos EstadosNação tem como consequência o enrijecimento das políticas e legislações migratórias, especialmente por parte daqueles Estados considerados como receptores de imigrantes, como se dessa forma pudesse combater o tráfico.

Para João Peixoto (2007), a partir dos anos 90 tornou-se muito visível a tensão entre a pressão crescente para a emigração, por parte de muitos países de origem, em sua maioria países subdesenvolvidos ou em desenvolvimento, e a restrição política à imigração, por parte de quase todos os países desenvolvidos de destino.

No entanto a intensificação dos fluxos migratórios pelo mundo e especialmente da migração irregular e o próprio tráfico de pessoas ganharam novos contornos com as políticas de combate ao terrorismo.

Nos EUA, após os atentados de 11 de setembro de 2001, dos atentados ao World Trade Center e ao Pentágono o tráfico de pessoas não só é referido como uma forma contemporânea de escravidão, mas encarado como uma das maiores ameaças da comunidade internacional, relacionando-o à guerra contra o terrorismo.

[...] o Presidente dos Estados Unidos, George Bush, por exemplo, cinco meses depois dos eventos do 11 de setembro de 2001, refere-se ao tráfico internacional de pessoas como uma "forma contemporânea de escravidão", e um ano mais 
tarde relaciona o fenômeno, em uma fala para a Assembleia Geral das Nações Unidas, à guerra contra o terrorismo. No debate contemporâneo, então, o tráfico não é somente interpretado como uma " moderna forma de escravidão", mas também como uma das maiores "ameaças" para a comunidade internacional. Além disso, a corrente referência ao tráfico classifica-o como o terceiro (ou, às vezes até, o segundo) comércio ilegal mais lucrativo depois do comércio de drogas e de armas; e são mencionados números exorbitantes como de que todo ano aproximadamente 1,2 milhões de pessoas seriam traficadas no mundo (Ausserer, 2007, p.15).

Assim o tráfico passa a ser considerado não só uma ameaça à segurança nacional, mas à comunidade internacional, cujo combate ao tráfico, passa pela repressão à imigração irregular.

De acordo com a CEPAL (2002) há uma tendência de restrição e controle cada vez mais rigorosos da imigração, contendo especialmente, o crescimento da imigração irregular.

Neste contexto acirra-se assim a visão do outro, estrangeiro/ migrante/ irregular. A identificação da pessoa traficada como migrante "ilegal" o constitui como outro. Deste modo, o imaginário da migração como forma de invasão desencadeia medos e ansiedades que são projetados neste outro. Neste sentido, além das políticas migratórias e anti-tráfico, também a constituição deste outro faz parte dos mecanismos de controle que se articulam. A reificação de certas categorias de pessoas como perigosas, estabelece uma estratégia política que visa a excluir estes grupos de pessoas (Cf. Donnan; Wilson apud Ausserer, 2007).

Assim, uma parte do discurso que coloca o migrante como outro culmina na reivindicação da desaparição deste, e encontra a expressão material nas políticas de deportação (Ausserer, 2007).

Esta percepção quer do migrante irregular ou traficado, traz consigo implicações políticas preocupantes, sublinhando o poder estatal em detrimento dos direitos das pessoas que migram ou que são traficadas, especialmente mulheres.

Contraditoriamente, à medida que as fronteiras dos Estados ficam mais restritivas e cresce a demanda por trabalho de migrantes a baixo custo e 0 desejo destes por novas oportunidades, a alternativa do deslocamento por meios não autorizados, como a migração irregular, acaba se intensificando.

Políticas restritivas de migração e imigração de países de trânsito e destino diminuíram as possibilidades de uma migração regular, legal e segura através do mundo. Este fenômeno resultou no aumento de um regime de migração clandestina no qual traficantes e contrabandistas facilitam o movimento dos 
migrantes, frequentemente providenciando para eles documentos de viagem e de identificação falsos. Este é um regime nascido do desejo e da necessidade das pessoas, produzido, em parte, pela demanda por trabalho explorado barato através das fronteiras (Kapur, 2005, p.119).

Este fato levou à organização crescente de intermediários, que aproveitaram esta conjugação de fatores para explorar o negócio da imigração irregular.

Os principais fluxos migratórios não autorizados envolvem, por um lado, formas mais ou menos sofisticadas de "contrabando" de imigrantes econômicos pelo auxílio organizado à imigração irregular, e, por outro lado, o "tráfico de pessoas", cujas maiores vítimas são as mulheres, além de crianças e adolescentes.

Para Peixoto (2007, p. 72),

Parte importante do debate científico em torno das questões do tráfico de migrantes tem rondado problemas conceptuais. A percepção generalizada indica que, sob uma designação muitas vezes comum, se encontram tipos muito diversos de movimentos. Estes variam em torno do grau de exploração econômica, níveis de engano e violência, grau de consentimento por parte dos indivíduos, propósito da deslocação e tipo de migrantes envolvidos (homens, mulheres ou crianças). A distinção mais importante, na bibliografia internacional, é aquela que separa o trafficking do smuggling ${ }^{41}$.

A diferenciação da concepção de tráfico e contrabando é bastante relevante e tal distinção encontra-se nos dois protocolos da Convenção das Nações Unidas contra o Crime Organizado Transnacional e inseridos no marco do controle e prevenção do crime organizado transnacional e na preocupação pelas violações das leis de imigração.

De acordo com o Protocolo Adicional relativo ao Combate ao Tráfico de Migrantes por Via Terrestre, Marítima e Aérea, contrabando deve ser entendido como o "facilitar da entrada ilegal de uma pessoa num Estado do qual essa pessoa não é nacional ou residente permanente com o objetivo de obter, direta ou indiretamente, um benefício financeiro ou outro benefício material"(art. $3^{\circ}$ ).

${ }^{41}$ Cf. também em Salt, 2000; Aronowitz, 2001; Kyle e Koslowski, 2001 
Artigo 3

Definições

Para efeitos do presente Protocolo:

a) A expressão "tráfico de migrantes" significa a promoção, com o objetivo de obter, direta ou indiretamente, um benefício financeiro ou outro material, da entrada ilegal de uma pessoa num Estado Parte do qual essa pessoa não seja nacional ou residente permanente;

b) A expressão "entrada ilegal" significa a passagem de fronteiras sem preencher os requisitos necessários para a entrada legal no Estado de acolhimento.

Porém nem toda migração irregular pode ser considerada contrabando, pois para ser contrabando precisa de uma pessoa ou grupo (contrabandista) que entremeie e facilite a entrada irregular no país de destino e lucre com isso.

Em geral, podemos admitir que as principais variáveis que fazem diferir a migração "normal" de trabalho, por um lado, de formas de tráfico e "contrabando" de migrantes (smuggling), por outro, é a presença de um agente externo (traficante ou contrabandista-smuggler), que funciona como intermediário, e o estatuto irregular dos movimentos. Neste aspecto, sabe-se que a intermediação dos fluxos migratórios é hoje uma área de interesse econômico crescente, devido à oferta e procura alargada de migrantes, em todo o mundo, e à possibilidade de colocar em contato os diferentes interesses em jogo (Peixoto, 2007, p. 72)

Em tese a relação entre o migrante e o considerado contrabandista de migrantes restringir-se-á à facilitação da travessia ilegal de fronteiras, quando os vínculos que os une se dissolvem e o migrante buscará, sozinho, sua sobrevivência no país de destino, inclusive procurando um novo trabalho (Gallagher, 2002). O objetivo do contrabando de imigrantes é a travessia ilegal das fronteiras, com benefício financeiro para o contrabandista. Porém isto pode não acontecer de forma tranquila e exatamente desta forma.

Já o tráfico de pessoas é definido pelo Protocolo Adicional à Convenção das Nações Unidas contra o Crime Organizado Transnacional relativo à Prevenção, Repressão e Punição do Tráfico de Pessoas, em especial Mulheres e Crianças, como:

Artigo $3^{\circ}$

Definições

Para efeitos do presente Protocolo:

a) A expressão "tráfico de pessoas" significa o recrutamento, o transporte, a transferência, o alojamento ou o acolhimento de pessoas, recorrendo à ameaça 
ou uso da força ou a outras formas de coação, ao rapto, à fraude, ao engano, ao abuso de autoridade ou à situação de vulnerabilidade ou à entrega ou aceitação de pagamentos ou benefícios de uma pessoa que tenha autoridade sobre outra para fins de exploração. A exploração incluirá, no mínimo, a exploração da prostituição de outrem ou outras formas de exploração sexual, o trabalho ou serviços forçados, escravatura ou práticas similares à escravatura, a servidão ou a remoção de órgãos.

Tráfico de pessoas e contrabando de migrantes são distintos. Apesar de ambos serem considerados meios de migração, o tráfico de pessoas se caracteriza pelo deslocamento de alguém, utilizando-se de coação, engano ou outros meios, com a finalidade da exploração do seu trabalho em vários setores de atividade. O contrabando de migrantes, por sua vez, se caracteriza pela facilitação da travessia ilegal de fronteiras, mas não tem, necessariamente, ligação com o trabalho ou a inserção e exploração do migrante no país de destino.

\section{Quadro 2- Movimento através de fronteiras}

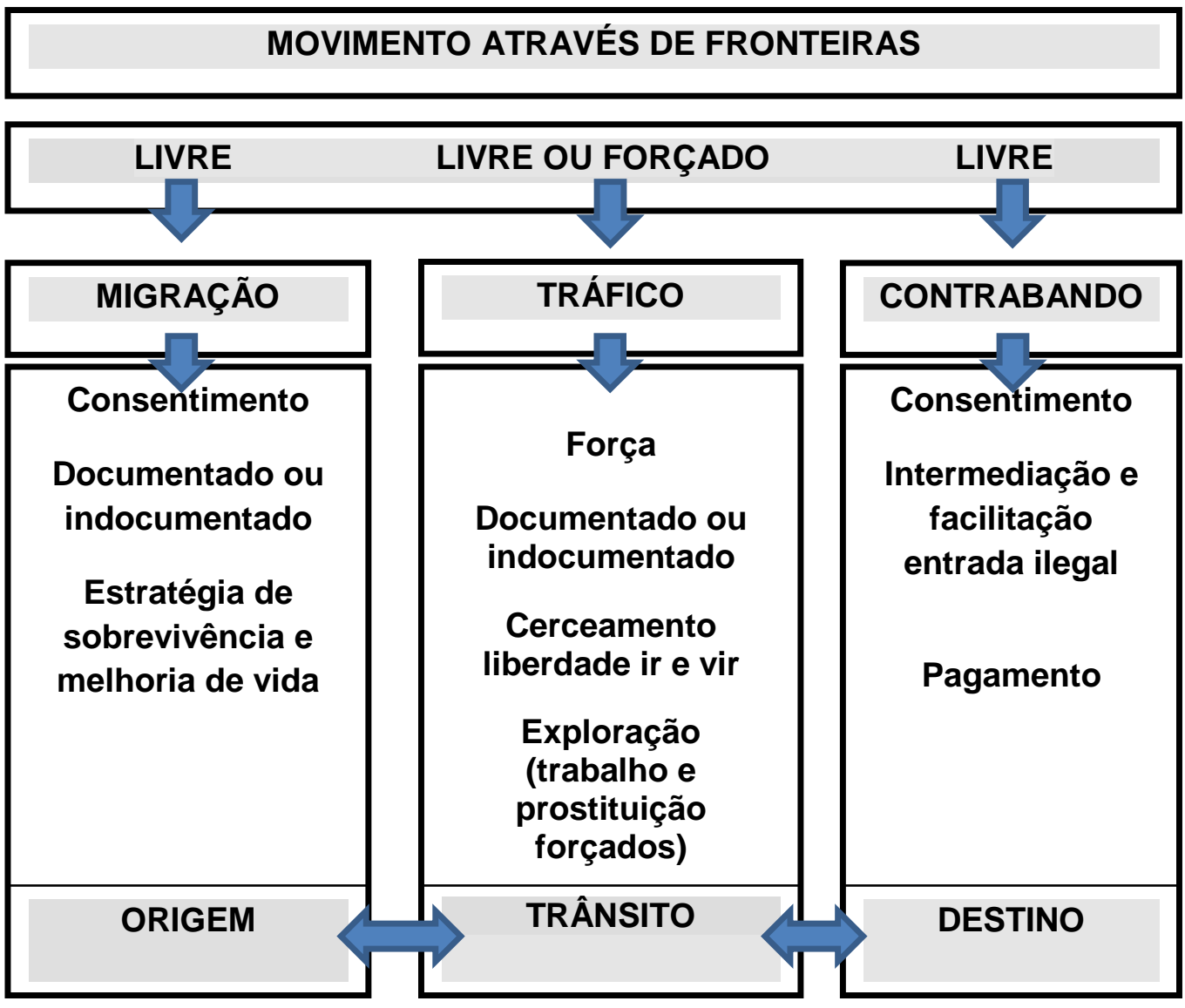

Fonte: Adaptado de: GAATW. Direitos Humanos e Tráfico de Pessoas: um manual. Tradução Patrick Carvalho e Luciana Campello Ribeiro, 2006. 
Enquanto o tráfico envolve a violência, fraude e exploração e é considerado um crime contra a pessoa o contrabando é um crime contra os Estados.

A prática de tráfico e aquela de contrabando se diferenciam conceitualmente, pois no tráfico se constitui um "sujeito-vítima" - que precisa ser salvo - versus um "sujeito-cúmplice" no contrabando - que deve ser considerado culpado e criminoso. Na prática quase não existem casos "puros" de contrabando ou de tráfico, e se constata que a maioria das estratégias de migração desafia a simples categorização (Bhabha; Zard, 2006, p.6).

$\mathrm{Na}$ expressão de Salt e Stein (1997), a migração é cada vez mais um "negócio", e o "tráfico/contrabando" é a face ilegal desse negócio. Alguma intermediação organizada dos fluxos sempre existiu, sobretudo nas épocas de migrações maciças de população, como sucedeu durante as migrações transoceânicas de final do século XIX e princípio do século XX. Mas o alargamento planetário dos fluxos, a melhoria dos meios de comunicação, a maior elaboração das políticas e as crescentes barreiras à entrada colocadas pelos países receptores têm levado a florescer diversos tipos de intermediação.

Contudo a clareza no plano conceitual que diferencia o tráfico do contrabando muitas vezes não se aplica à realidade. Na observação de casos concretos de tráfico e contrabando de pessoas verificam-se inúmeras áreas de indeterminação existentes, pois movimentos que começam como simples "contrabando" (auxílio na passagem de fronteira) podem vir a envolver graus elevados de exploração econômica ou, mesmo, abuso e violência física, que caracterizaria o tráfico.

No entanto, parece que as principais variáveis que separam o tráfico do "contrabando" de migrantes são a presença de formas de exploração, coação, violência e fraude - ou, mais em geral, o abuso e violação dos direitos humanos.

As vítimas de tráfico são geralmente mantidas nos países de destino em regime de total ou "quase" escravidão, submetidas às mais diversas formas de coação, inclusive ao do pagamento da dívida dos pesados custos assumidos em seus países de origem, a título de transporte e documentação, além de ameaças de violência à pessoa e de dano a sua família no país de origem, há também, em algumas atividades de exploração, a introdução da pessoa ao uso de drogas como forma de evitar fugas e assegurar a permanência na exploração. 
As máfias exploram as condições dramáticas de vida que assolam as populações dos países mais pobres. As falsas promessas dos aliciadores encontram terreno fértil nos países e nas classes sociais que mais sofrem pela falta de oportunidade e perspectiva para o futuro. Não raramente, as vítimas dos aliciadores desconfiam da veracidade das encantadoras promessas dos algozes, mas preferem arriscar antes que permanecer nas desumanas condições de vida em que se encontram (Marinucci \& Milesi, s.d.)

O tráfico internacional de pessoas, além de um crime, é um negócio desumano e degradante. Uma prática que nega valores inerentes à dignidade humana, como o direito à liberdade, o direitos de escolha, o direitos à integridade física e psíquica, dentre outros, afrontando os direitos humanos.

Porém, para prevenir o contrabando e o tráfico de pessoas, são estabelecidas políticas migratórias mais repressivas. Os "países receptores" que consideram o tráfico como uma ameaça para a segurança nacional, encontram na deportação ${ }^{42}$ das pessoas traficadas, que são principalmente mulheres, uma solução convertendo as vítimas em criminosos.

Outro aspecto é que em alguns países a proteção à vítima de tráfico está condicionada a sua cooperação nas investigações e no processo judicial. Porém isto não garante o auxílio e a proteção necessária à vítima, que se desmotiva a denunciar, tendo em vista o risco e o receio de represália por parte dos criminosos que a traficaram.

Saari (2006) ressalta que, no caso dos Estados que fazem parte da União Europeia (de trânsito e de destino por excelência), as pessoas traficadas não costumam procurar as autoridades, o que favorece a atuação dos traficantes. Isso porque elas têm medo de serem detidas e deportadas, além do que, ao testemunharem contra os criminosos, há o risco de revanche, sem nenhuma garantia dos Estados de recebimento ou de origem.

Para Kempadoo (2005),

Um dos efeitos mais impressionantes é que, embora as pessoas objeto de tráfico sejam designadas como "vítimas" em várias políticas e leis, a menos que se tornem informantes da polícia e entreguem seus "traficantes", que bem podem ser seus amigos, amantes, irmãos, irmãs, ou seus empregadores, elas são tratadas como imigrantes ilegais, criminosas ou ameaças à segurança nacional. Números crescentes de imigrantes pobres são então adicionados ao número já imenso de pessoas processadas pelos sistemas de justiça criminal, com números também crescentes, sendo detidas ou encarceradas por crimes não violentos como imigração ilegal, uso e tráfico de drogas, e trabalho sexual.

\footnotetext{
${ }^{42}$ Ato de um Estado no exercício do seu poder de soberania que se traduz na expulsão de um estrangeiro do seu território para um determinado lugar, após a recusa de admissão ou expiração do prazo de validade da autorização de permanência.
} 
Essa abordagem serve mais para proteger os objetivos do Estado do que para proteger a pessoa traficada. De fato, prevenir o tráfico significa evitar que imigrantes irregulares entrem no país ou permaneçam nele.

Pesquisas realizadas pelas principais organizações não governamentais contra o tráfico ${ }^{43}$ mostram que, além da prisão, detenção e deportação, pessoas traficadas, quando "resgatadas", são em geral devolvidas aos países de origem como migrantes sem documentos, e têm de enfrentar a vergonha e a humilhação que acompanha tal categorização e o status de deportadas. Há também o medo de represálias dos traficantes ou o medo de que a família ou a comunidade de origem estigmatize, principalmente sendo uma mulher, por seu envolvimento em atividades sexuais tidas como criminosas (Kempadoo, 2005).

O tratamento do tráfico de pessoas como problema de migração ultrapassa a simples associação com a migração irregular.

É possível que formas voluntárias, não voluntárias, legais e ilegais se misturem no processo de migração, dificultando ainda mais uma distinção nítida entre as diferentes formas de migração. Mas, no tráfico, a ênfase é na presença dos elementos da força e da coação.

O tráfico de pessoas, porém não surge exclusivamente de processos de migração forçada, mas que é possível também ser resultante de diferentes formas de migração voluntária, ou seja, consentida pela pessoa. No entanto, o consentimento nos casos de tráfico, é irrelevante.

Para Salt (2000, p.34) a relação entre tráfico e contrabando desafia as teorias migratórias, pela dificuldade de diferenciação entre movimentos forçados ou "ilegais" e aqueles voluntários e "legais", e ainda problematizam a questão do consentimento.

Em síntese, e como tem sido expresso por numerosos autores, existe um grande continuum de situações entre o tráfico de pessoas, em sentido estrito, e o "contrabando" de migrantes ou auxílio à imigração irregular (Salt, 2000, entre outros).

Nesses casos, o proveito com o recrutamento de agentes do movimento de pessoas, e desde que as condições subsequentes dessas pessoas são indiferentes para eles (eles seriam pagos não importa se as pessoas que eles deslocaram são abusadas ou exploradas, ou livre e bem pagas), eles não podem ser descritos como tendo a intenção de sujeitar a vítima do transporte coercitivo a violações adicionais na forma de trabalho forçado ou práticas análogas à

\footnotetext{
${ }^{43}$ São algumas dessas organizações: Dutch Foundation Against Trafficking in Women (STV) [Fundação Holandesa contra o Tráfico de Mulheres], a Global Alliance Against Traffic in Women [Aliança Global contra o Tráfico de Mulheres], com base na Tailândia, assim como a Anti-Slavery International [Internacional Contra a Escravidão] no Reino Unido (KEMPADOO, 2005).
} 
escravidão. Mas se "smuggling" é entendido para se referir a uma relação voluntária e consensual entre migrantes e aqueles que facilitam sua migração, então este último tipo de agente de recrutamento não poder ser apropriadamente descrito como "smuggler" (Anderson \& Davidson, 2004, p.21).

Além disso, a contratação de um intermediário para facilitar a entrada irregular em outro país, não garante que não possa se tornar uma situação de tráfico, se, durante o percurso e quando chegar ao destino a pessoa pode ser explorada para o trabalho forçado, incluindo a prostituição forçada.

Os movimentos populacionais aos quais se costumam aplicar estes conceitos são diversos. Eles incluem migrações econômicas de trabalho, fluxos de mulheres destinadas à exploração sexual e tráfico de crianças. A variedade dos movimentos reflete os desafios teóricos enunciados. Em certa medida, alguns destes fluxos confundem-se com outros e sobrepõem-se entre si (Peixoto, 2007, p.4).

A produção por parte do Estado da "ilegalidade" de quem migra, possibilita-o manipular as classificações ora como migrante irregular (criminoso) ora como pessoa traficada (vítima) e legitimar um aumento de controle contra os sujeitos em mira, que, por sua vez, estão caracterizados pela vulnerabilidade da onipresente possibilidade de deportação, constituindo forças de trabalho baratas e "descartáveis".

A percepção do migrante como outro "ilegal", associa-se um olhar sobre o outro como criminoso que deve ser punido. Sem documentos e sem nenhum apoio atribui-se a eles o medo de uma "invasão migratória", os riscos de desemprego para os trabalhadores autóctones, a perda da identidade nacional e, até, o espectro do terrorismo, justificando sua exclusão da comunidade política e dos direitos relacionados.

Assim é que alguns países, ao combater o tráfico de pessoas, cujo contingente de mulheres é significativo, centram-se na contenção e controle da migração, principalmente irregular, alimentados pela xenofobia, deixando de lado a criação de mecanismos que garantam os direitos humanos da pessoa traficada que precisa de proteção e assistência.

Essa atitude coloca os interesses migratórios da sociedade de destino acima da proteção dos direitos humanos dos imigrantes, mesmo daqueles que foram traficados, que ficam expostos a vários tipos de exploração e violências, perpetrados inclusive pelos próprios Estados. 
Criticando essa posição, Neide Patarra (2008) ressalta que devem ser considerados nestes contextos, os compromissos em prol dos direitos humanos dos migrantes:

É imprescindível que se considere, hoje, o contexto de luta e compromissos internacionais assumidos em prol da ampliação e efetivação dos Direitos Humanos dos migrantes; é preciso se reconhecer o novo, difícil e conflitivo papel dos Estados Nacionais e das políticas sociais em relação aos processos internacionais e internos de distribuição da população no espaço, cada vez mais desigual e excludente; há que se tomar em conta as tensões entre os níveis de ação internacional, nacional e local; há que se considerar que os movimentos migratórios internacionais constituem a contrapartida da reestruturação territorial planetária intrinsecamente relacionada à reestruturação econômico-produtiva em escala global (p.1).

É necessário um compromisso dos Estados com uma governabilidade das migrações que assegure não só os interesses políticos e econômicos destes, mas o efetivo respeito aos direitos humanos dos migrantes, sob responsabilidade da permanência da violência e violações quando no deslocamento e inserção em do migrante no país de destino. 


\section{Condição de Gênero, Migração e Tráfico na Trajetória de Mulheres Emigrantes da Região Metropolitana do Estado do Rio de Janeiro}

Esse capítulo é dedicado à análise de cunho qualitativo das histórias de vida de cinco mulheres brasileiras migrantes residentes na região metropolitana do Estado do Rio de Janeiro.

A análise privilegiou a apreensão dos nexos existentes entre a condição de gênero, migração e tráfico, a partir das diferentes experiências narradas por estas mulheres, buscando verificar como elas percebem e resignificam as suas trajetórias de migração. Os pontos analisados foram: a motivação na decisão de sair do país, a sua permanência no país de destino, a decisão de retornar ao Brasil, assim como suas expectativas, sonhos, conquistas, amores e desamores, fracassos e sofrimentos diante de situações de discriminações, preconceito e violência.

Procurou-se identificar também, a existência de fatores que colocaram essas mulheres em situações de risco pessoal e social e de violação de direitos quando no processo migratório, observando como estas perceberam as ações dos diversos sujeitos (Estado, organizações da sociedade civil, família, amigos, grupos criminosos e outros) e as estratégias utilizadas por elas na superação das dificuldades e no cessar das violações.

\section{1 \\ Contextualizando a pesquisa de campo}

Foram entrevistadas cinco mulheres residentes na região metropolitana do Estado do Rio de Janeiro. Todas as entrevistas foram realizadas no período que compreende janeiro a julho de 2011, totalizando aproximadamente 12 horas de gravação. Os relatos foram gravados com autorização das entrevistadas, com a finalidade de uma fiel reprodução das histórias, com no mínimo 1 hora de 
duração e até no máximo 3 horas cada, sendo realizadas em locais indicados pelas entrevistadas, visando deixá-las mais à vontade.

Privilegiou-se como método a história de vida, cuja escolha deste, dentre outros, se deveu à possibilidade de maior liberdade para o entrevistado relatar aquilo que the é significativo e interessante. Para Glat (1993), a principal vantagem deste tipo de abordagem, é que "garante que a tendência observada ou os fatos considerados dignos de interesse científico, são os apontados pelos próprios sujeitos, e não aqueles que o pesquisador, de fora e a priori, achava que ia encontrar; geralmente, comprovando sua hipótese"(p. 16).

No uso do método história de vida, não há limite de duração para a entrevista, que varia de acordo com a disposição do sujeito, se encerrando, naturalmente, quando o depoente não tem mais nada a acrescentar. não há, igualmente, uma determinação rígida quanto ao número mínimo de sujeitos a serem entrevistados. a coleta de dados é considerada completa quando se chega ao que Bertaux (apud Spindola; Santos, 2003) denomina de ponto de saturação: "quando, a partir de certo numero de entrevistas, o pesquisador tem a impressão de não apreender nada de novo no que se refere ao objeto de estudo" (p. 46).

Sem a pretensão de generalização do conhecimento produzido a partir destas vivências particulares, advindas das histórias de vida destas mulheres, se reconhece, no entanto, que estas narrativas também informam as relações e contextos sociais mais amplos em que estas se inserem.

Nesse sentido, as histórias de vida, por mais particulares que sejam, são sempre relatos de práticas sociais: das formas com que o indivíduo se insere e atua no mundo e no grupo do qual ele faz parte (Bertaux apud Spindola; Santos, 2003)

Para Brioschi e trigo (1987), o método de história de vida ressalta o momento histórico vivido pelo sujeito. assim, esse método é necessariamente histórico, dinâmico (apreende as estruturas de relações sociais e os processos de mudança) e dialético (teoria e prática são constantemente postas em confronto durante a investigação).

O relato colhido é uma "produção de si" que o sujeito elabora (Bordieu apud Preuss, 1997) e não uma "apresentação de si". A maneira como o indivíduo conta oferece o acesso a outras dimensões, como ao sociológico, a ponte entre sujeito e coletivo. Ao contar sua vida, o sujeito fala de seu contexto - fala do processo por ele experimentado, intimamente ligado à conjuntura social onde ele se encontra inserido. Ao se trabalhar o vivido subjetivo dos sujeitos, através do 
método de História de vida, temos acesso à cultura, ao meio social, aos valores que ele elegeu e, ainda, à ideologia (Silva, 2007, p.32-33).

Para Becker (1999) entre as contribuições que a história de vida é capaz de dar, uma como fundamental: "a história de vida, mais do que qualquer outra técnica, exceto, talvez, a observação participante, pode dar um sentido à superexplorada noção de processo (p.109)". Para Harguette (1987) este "processo em movimento" requer uma compreensão íntima da vida de outros, o que permite que os temas abordados sejam estudados do ponto de vista de quem os vivencia, com suas suposições, seus mundos, suas pressões e constrangimentos.

A busca e a escolha das mulheres para a participação da pesquisa contemplou os seguintes critérios: a) residirem no Estado do Rio de Janeiro; b) ter uma experiência de emigração, independente do país de destino; c) ter retornado ao Brasil, por deportação ou de qualquer outra forma; d) ter vivido ou não alguma situação de "violência" e/ou de "tráfico de pessoas".

O primeiro critério, de residirem no Rio de Janeiro foi adotado devido à impossibilidade de deslocamento para fora do Estado. A não delimitação a priori de municípios se deveu ao caráter exploratório desta pesquisa, tendo em vista a inexistência de dados sobre a situação do tráfico de pessoas no Estado do Rio de Janeiro que pudesse orientar sobre locais de maior incidência de aliciamento para o tráfico ou mesmo aqueles com maior incidência de mulheres que emigraram.

O segundo critério adotado por essa pesquisa pretendeu contemplar, a motivação destas mulheres em saírem do país - quer para trabalho, estudo, casamento, reunificação familiar, fuga de situação de violência ou outras situações. Além de identificar as redes de apoio no país de origem e de destino e as condições de permanência delas no país de destino, identificando o papel das relações de gênero presentes nestas.

O terceiro critério, de retorno ao Brasil, além das limitações de deslocamento para realização do trabalho de campo, já mencionadas anteriormente, foi adotado também devido ao fato de que o regresso possibilitaria às mulheres maior distanciamento e melhores condições para a análise deste período de suas vidas. O significado deste retorno, a reorganização de suas vidas e relações, bem como na identificação dos sujeitos que colaboraram e fizeram parte de sua história (família, amigos, organizações 
não governamentais, Estado e outros), poderiam ser melhor dimensionados com o passar do tempo.

A vivência de situações de violência e/ou tráfico de pessoas, último critério adotado, se fez importante tendo em vista a proposta deste estudo, procurando identificar em que momento estas situações ocorreram na migração e que fatores favoreceram para que estas mulheres tivessem seus direitos violados, utilizando estas informações sempre em comparação com a trajetória de outras mulheres que não vivenciaram estas mesmas situações.

A partir destes critérios viu-se a possibilidade de localizar mulheres para participarem da pesquisa, durante viagens de trabalho, como docente do Curso sobre Enfrentamento à Exploração Sexual e ao Tráfico de Pessoas, promovido pelo Projeto Trama em parceria com a Secretaria Especial de Políticas para as Mulheres do governo federal.

O curso foi oferecido em dez municípios do Estado do Rio (que agregaram outros municípios próximos) e oportunizou durante um ano, o estabelecimento de contato com profissionais que prestavam atendimento direto à população. Eram profissionais ligados às áreas de saúde, assistência social, segurança pública e núcleos de atendimento à mulher; além de conselheiros de direitos e conselheiros tutelares e mulheres ligadas a movimentos sociais.

A despeito disso, porém, chegou-se a apenas um único caso, pois o curso permitiu verificar que não havia até então, por parte destes profissionais, um conhecimento da temática do tráfico de pessoas, o que, independente de sua ocorrência ou não, dificultava a identificação dos mesmos. As informações fornecidas pelo curso aos participantes, sobre o tema em questão, trouxeram à lembrança situações envolvendo a exploração sexual de crianças e adolescentes e o trabalho escravo de adultos.

A grande dificuldade encontrada em localizar estas mulheres, principalmente as que haviam vivido situações de violência e tráfico de pessoas, levou ao contato com o Projeto Trama ${ }^{44}$, o que possibilitou a localização de quatro mulheres.

Fez-se também o contato com o Núcleo de Enfrentamento ao Tráfico de Pessoas vinculado à Secretaria de Assistência Social e Direitos Humanos do Estado do Rio de Janeiro, porém não foi possível o acesso a nenhum de seus

\footnotetext{
${ }^{44}$ Consórcio entre as instituições não governamentais: Instituto Brasileiro de Inovações em Saúde Social; Organizações de Mulheres Negras- CRIOLA; Organização de Direitos Humanos Projeto Legal; e Universidade UNIGRANRIO, criado em 2004, com sede na cidade do Rio de Janeiro, com o objetivo de prevenção e enfrentamento ao tráfico de pessoas, que envolvem não só exploração sexual, mas também a violação de direitos de migrantes.
} 
casos, pois foi avaliado que o acesso às mulheres atendidas poderia ser prejudicial a elas, tendo em vista a situação de fragilidade em que se encontravam quando do atendimento pela instituição.

Como informou a então coordenadora do Núcleo, havia na ocasião poucos casos, encaminhados pelo Posto Avançado de Atendimento Humanizado aos Migrantes no Aeroporto Tom Jobim e outros órgãos, como Ministério da Justiça e CREAS- Centro de Referência Especializado de Assistência Social. O encaminhamento é realizado somente quando existe a suspeita de tráfico de pessoas. Quando há confirmação de tráfico os casos são atendidos e acompanhados pelo Núcleo, podendo ser encaminhadas também para Projeto Trama, já mencionado anteriormente.

Os casos chegam de várias formas, hoje neste pequeno período desta gestão de $4 / 5$ meses, que estamos coordenando, teve 4 casos. Acho que eles são emblemáticos para comentar, porque cada um deles chegou por uma via diferente. Então, via de regra, acha-se que vão chegar pelo aeroporto, no aeroporto nossa base é o posto avançado de atendimento humanizado ao migrante, que é um serviço da prefeitura, que atua por meio de um convênio como Ministério da Justiça, um convênio análogo ao nosso com o Ministério da Justiça, mas é importante frisar que é um serviço do município, é da Guarda Municipal, mas atuamos muito em parceria.

Então a gente tem demanda desde para prestar informações a alguém que está chegando ao aeroporto e, se esta for a única demanda o posto acaba já cumprindo esta função, com informações básicas, jurídicas ou mesmo de chegada, pois às vezes a pessoa está chegando aqui e não é daqui, é de outro estado, perdeu o contato com os familiares e muitas vezes não chega ao Núcleo, principalmente quando não tem a situação de tráfico configurada. Se há uma situação de tráfico nós já somos notificados. Eles entram em contato conosco e vamos até o caso, para fazer este atendimento de reconhecimento, acionando os serviços de acordo com as necessidades então (Entrevista com Nina Quiroga, em julho de 2011, coordenadora do Núcleo de Enfrentamento ao Tráfico de Pessoas no Rio de Janeiro).

O Posto Avançado de Atendimento Humanizado aos Migrantes no Aeroporto Internacional Tom Jobim (Galeão) ${ }^{45}$,e a organização não governamental, Prevenção Madalena's, situada em Niterói, também foram contatadas, mas não se conseguiu em tempo hábil, agendar uma entrevista com as pessoas indicadas por estas instituições.

Outras mulheres a que se teve acesso surgiram no decorrer da pesquisa, a partir do trabalho realizado como assistente social e docente.

\footnotetext{
${ }^{45}$ O Posto Avançado de Atendimento Humanizado aos Migrantes no Aeroporto Internacional Tom Jobim é vinculado a Prefeitura do Rio através da Guarda Municipal, e funciona através de uma parceria com o Ministério da Justiça. Realizam a recepção a brasileiros não admitidos ou deportados do exterior e estrangeiros com problemas de entrada no Brasil ou no exterior. No local, também são atendidas e identificadas possíveis vítimas do tráfico de pessoas.
} 
Após este percurso foi identificado um total de 17 mulheres, potenciais participantes desta pesquisa, algumas inclusive indicadas por mulheres já contatadas pela pesquisa.

Deste total 5 se dispuseram a dar entrevista e as restantes não puderam ou não quiseram participar por motivos variados: algumas não estavam mais morando no Rio e outras se recusaram a participar justificando, cada uma a seu modo, que viviam agora outro momento e não tinham interesse em narrar as suas histórias.

Utilizou-se um roteiro simples para nortear a pesquisadora, porém nas entrevistas foi solicitado a cada uma das participantes que narrassem sua trajetória de migração (motivação de saída, permanência no exterior e retorno), deixando-as livres para falar, com pouquíssimas intervenções da pesquisadora, apenas para solicitação de algum esclarecimento de algo que não tivesse ficado claro no relato.

Para Cipriani (1988), o "livre fluir do discurso" é considerado uma condição indispensável para que vivências pessoais despontem profundamente entranhadas no social, o processo de "escavação do microcosmo" deixa entrever o "macrocosmo". O universal mostra-se invariavelmente presente no singular; pois cada entrevista pode ser tomada na sua totalidade compondo um discurso único e singular. Assim, a singularidade das histórias de vida advém do fato de que não se consegue chegar ao geral, através de uma diversidade de histórias de vida singulares, sem dar a elas uma totalidade sintética, que por sua vez se forma a partir da singularidade de cada uma delas.

A história de vida encerra um conjunto de relatos e, que embora se tenha escolhido o tema e elaborado um roteiro temático, são as entrevistadas que decidem o que narrar, aprofundando determinados assuntos e se afastando de outros, reconstruindo do seu modo as lembranças e as suas significações.

Das entrevistadas, duas se identificaram como vítimas do tráfico de mulheres.

As outras entrevistadas, apesar de narrarem situações de constrangimento, discriminação, preconceito e diversos tipos de violência, retratam situações que não são caracterizadas como tráfico de mulheres; contudo trazem elementos que possibilitam verificar como a condição social e econômica, bem como a condição de gênero e de raça foi identificada por estas mulheres como aspectos que incidirão sobre seus projetos de vida no exterior.

Um relato em particular, de uma das mulheres entrevistadas, retratou bem os limites da conceituação do que seria tráfico de mulheres, pois as 
situações relatadas envolviam a coação, o engano, a servidão e a violência, fatores estes que poderiam caracterizar esta situação como sendo de tráfico, porém não foi considerado como tal, nem pela entrevistada e nem pelas instituições que lhe prestaram apoio.

Esta talvez seja a grande riqueza trazida por esta pesquisa: a complexidade das experiências vividas por estas mulheres que decidiram emigrar, mostrando por um lado, a reprodução de relações de poder, que expõe esta mulher tanto a uma situação de subjugação e violência no país de destino, quanto revela a capacidade destas de criar estratégias de superação e sobrevivência.

O que permitiu na pesquisa repensar sobre o conhecimento já construído sobre o tráfico de mulheres, trazendo as ambiguidades e as contradições no enquadramento de determinadas mulheres como possíveis vítimas do tráfico.

$\mathrm{Na}$ realização das entrevistas, foram adotados os quatro referenciais básico da bioética expressos na Resolução no 196/96 do Conselho Nacional de Saúde: autonomia; beneficência, não maleficência; justiça e equidade. Todas as entrevistadas formalizaram o consentimento assinando o Termo de Consentimento Livre e Esclarecido, em duas vias, uma para a entrevistada e outra da pesquisadora.

Em complemento à Resolução foram seguidas as "Recomendações de Ética e de Segurança para Entrevistar Mulheres Traficadas" da Organização Mundial de Saúde (2003). Dessa forma garantiu-se que, em momento algum, na análise dos dados e eventuais publicações colocar-se-á em risco as pessoas, não mencionando nomes, apelidos, datas de nascimento, comunidades em que moram ou frequentam, locais de trabalho, bem como quaisquer outras citações que possam vir a ensejar uma identificação pessoal. Assim, para não haver nenhuma possibilidade de identificação, utilizou-se pseudônimos para as entrevistadas e as pessoas envolvidas em suas histórias ${ }^{46}$.

\footnotetext{
${ }^{46}$ Procedimento que é, ademais, o procedimento regularmente adotado em pesquisas antropológicas.
} 


\section{2 \\ Trajetórias das mulheres entrevistadas}

O universo das mulheres que participaram desta pesquisa mostra uma diversidade, não só em relação à idade, cor de pele, local de residência, escolaridade, mas, principalmente em relação as suas trajetórias de migração.

No momento da entrevista, as entrevistadas tinham idades entre 29 e 49 anos; uma informou estar vivendo em união estável e as outras informaram ser solteiras. Três definiram sua cor de pele como morena, uma referiu a si mesma como mulata e outra como branca.

A escolaridade dessas mulheres variava entre o ensino fundamental incompleto ao superior completo e com exceção de uma, que possui uma condição social melhor por ser funcionária pública, as outras possuem baixa renda.

Três residiam na cidade do Rio de Janeiro (Pavuna, Copacabana e Jardim América), uma no município de Duque de Caxias e outra no município de São Gonçalo.

Estas mulheres emigraram quando tinham idade entre 14 e 35 anos, com destino a Portugal, Itália e Espanha nas décadas de 1970, 1980, 1990 e 2000. Uma delas continua migrando, por ter fixado residência na Itália.

Todas trazem relatos de vida, resignificados por elas, que ilustram experiências diversas vivenciadas no processo migratório.

LUIZA, 49 anos, cursou o fundamental incompleto, reside no Município de São Gonçalo e participa como voluntária em um projeto social com adolescentes. Ela foi a primeira mulher que entrevistamos e o contato se deu através da atividade docente num curso ministrado pelo Projeto Trama em parceria com a Secretaria Especial de Política para as Mulheres, que como já informado, foi realizado em vários municípios do Estado do Rio de Janeiro. Durante um dos módulos, Luiza levantou-se e passou a relatar a sua história para todos os presentes, dizendo ter sido traficada, o que foi confirmado pelos profissionais que acompanham o seu caso e que também estavam participando do curso.

O acesso à Luiza foi difícil, pois na ocasião a mesma estava com problemas no telefone de sua residência e não tinha celular. Para que fosse viabilizada a entrevista, optou-se por entrar em contato com a assistente social 
que acompanhava Luiza, através de uma instituição que também lhe prestava assistência e apoio psicológico. Luiza apresentava uma situação difícil de saúde, pois estava em tratamento devido a um câncer, à AIDS e sequelas de leptospirose.

No dia marcado, ela havia acabado de sair de um atendimento com a psicóloga e estava muito desnorteada, dizendo que não estava bem para conversar. A entrevista foi então desmarcada e posteriormente foi reagendada para uma semana depois, quando se realizou a entrevista.

Luiza relatou três saídas para o exterior, na década de 70, 80 e 90, a partir de seu vínculo com uma Escola de samba da zona norte do Rio e posteriormente com o trabalho como sambista para casas de Show na zona sul do Rio. O relato em alguns momentos apresentou-se como um conjunto de lembranças fragmentadas. Ao final da entrevista, foi possível compreender que o envolvimento com as drogas e as sequelas deixadas pelas doenças que ela relatou ter contraído, justificavam tais fragmentos.

Luiza narra a sua primeira saída do país na década de 1970 quando tinha 14 anos, com a permissão dos responsáveis e com a autorização do Consulado brasileiro e do Consulado português para apresentação de um espetáculo sobre - Carnaval em Portugal, produzido por uma Escola de Samba da zona norte do Rio e financiado por donos de hotéis e da rede de turismo. De acordo com Luiza, o presidente da Escola de Samba era seu padrinho e pensou em fazer um show para o exterior com as meninas de Nova Iguaçu e de outros municípios da Baixada Fluminense. Esta primeira viagem ocorreu sem problemas e despertou nela o desejo de ser famosa e ganhar dinheiro.

Foi somente em sua segunda viagem aos 26 anos, na década de 1980,mediante proposta de donos de boates no Rio e São Paulo para realizar shows de samba em Portugal, com um contrato de 30 dias, que ela revela ter sido vítima de tráfico. Após um mês trabalhando em shows, em situação irregular, tentaram forçá-la a se prostituir e foi quando fugiu. Mesmo assim para sobreviver se envolveu com prostituição e com drogas ilegais.

Em sua terceira, viagem na década de 1990, já envolvida com prostituição, trabalhava em uma boate na zona sul do Rio como sambista e foi financiada para fazer show na Itália e Portugal. Quando retornou, havia contraído uma dívida enorme que pagou trabalhando na boate, não recebendo nenhum dinheiro durante meses.

PATRÍCIA, 35 anos, foi contatada através de uma pessoa conhecida. A entrevista foi em seu apartamento, uma quitinete em Copacabana, que conta 
com orgulho ter conseguido comprar através de seu trabalho na Itália. Ela relatou ter vindo de uma família de "camelôs", cuja maioria ainda vive do comércio autônomo. Saiu do Brasil a primeira vez em 2000, quando tinha 23 anos, para trabalhar na Itália, onde sua irmã já morava há alguns anos, e por isso resolveu se arriscar, apesar de não ter um bom relacionamento com a irmã. Trabalhou em restaurante, como empregada doméstica e viu que tudo era muito difícil. Então, depois de 2 anos e meio decidiu retornar ao Brasil.

Trabalhou no Brasil numa empresa de confecção de biquínis e sandálias e através deste trabalho surgiu a oportunidade de retornar à Itália, com a promessa de que a empresa providenciaria o documento de permanência, o que efetivamente não aconteceu. Além de explorá-la com uma jornada excessiva de trabalho, não providenciaram o documento de permanência. Resolveu, então, ter sua própria confecção, comprou um casamento falso para ser cidadã italiana e hoje tem residência no Brasil e na Itália. Conheceu um italiano com quem teve um relacionamento mais sério, o qual proporcionou a ela um suporte para que se mantivesse na Itália. Hoje ela transita de um país a outro vendendo biquínis.

O contato com GEANE ocorreu em 2006, em uma Campanha realizada pelo Projeto Trama no Aeroporto Internacional Tom Jobim. O contato posterior para a pesquisa foi solicitado ao Projeto Trama, pois o telefone que na ocasião ela havia fornecido estava desatualizado. Foram quatro tentativas de realização da entrevista. Em todas as vezes ela confirmava, mas no dia sempre acontecia algo que, segundo ela, impedia seu comparecimento. Chegou-se a avaliar que não seria possível entrevistá-la, pois ela estava cada vez mais inacessível, até que marcou conosco na terça feira de Carnaval de 2011 antes da saída do Bloco organizado pelo pai de uma amiga. Finalmente neste dia ela compareceu no local marcado e a entrevista aconteceu em sua casa, uma pequena quitinete alugada numa vila de quartos na Pavuna.

Geane tem 41 anos, é diarista e cursou até a $3^{\text {a }}$ série do ensino fundamental. Ela narrou que não pensava em ir para o exterior até que, um dia, foi convidada por uma amiga, que considerava como uma irmã, inclusive morava na casa dela com um dos seus dois filhos. Esta amiga já havia viajado anteriormente para Espanha com um grupo de dança organizado por uma Escola de Samba da zona norte do Rio, que promovia espetáculos.

Durante a viagem, contrariando as normas do grupo, esta amiga conheceu um espanhol e virou amante dele, se envolvendo também com a prostituição em um dos prostíbulos mantidos por este homem. Ao retornar, essa amiga decidiu formar seu próprio grupo, patrocinado pelo espanhol, convidando 
Geane e outras mulheres e homens do antigo grupo ligado à Escola de Samba, com a promessa de ganhos maiores. Assim embarcaram para Espanha em julho de 1998 e depois de três meses Geane conta que passaram a exigir que além dos shows se prostituíssem para pagar tudo o que foi gasto com elas.

O caso foi denunciado à Polícia Federal no Brasil como tráfico de mulheres pela mãe de uma delas, chamada Tatiane, amiga de Geane e que juntamente com ela se negou a ir para o prostíbulo. Geane narrou que foram ameaçadas, os passaportes retidos, não receberam pagamento de salário pelos shows e não tiveram acesso à alimentação. Segundo ela, a aliciadora também forjou o furto de dinheiro para incriminar Geane e Tatiane, denunciando-as por furto à polícia espanhola, mas elas conseguiram escapar desta falsa acusação e, com ajuda de pessoas amigas na Espanha e da família de Tatiane no Brasil, conseguiram retornar ao nosso país. A aliciadora foi presa tempos depois em terras brasileiras, quando retornou para a festa de 15 anos da própria filha.

Outra entrevistada foi VIVIANE, 29 anos, que cursou o ensino fundamental incompleto, tem duas filhas menores e estava grávida de 7 meses quando da realização da entrevista. Chegou-se até ela através do Projeto Trama. Moradora de uma favela não pacificada em Jardim América, decidiu marcar a entrevista na casa da mãe dela, residente na entrada da referida favela. Foram três tentativas, antes da realização da entrevista, que aconteceu na porta da casa da mãe dela, local escolhido por Viviane, devido à casa de sua mãe ser muito pequena e neste dia estarem lá algumas crianças, filhas de Viviane e seus irmãos. Acomodadas em dois bancos fornecidos por sua mãe e sob o olhar curioso dos poucos pedestres que passavam pela rua naquele momento foi realizada a entrevista.

Viviane narrou que a decisão de ir para Portugal em 2007, não foi dela, mas do ex-marido. Na ocasião ela tinha 23 anos e havia se casado com ele quando ainda era adolescente, com 15 anos.

O ex-marido já havia viajado irregularmente para os EUA, influenciado pelo cunhado, permanecendo por um ano. Nem bem retornou, logo depois decidiu ir para Portugal, vendendo o carro que havia comprado com o dinheiro trazido dos EUA, assim como outros objetos a fim de custear a passagem. Ele acreditava que ganharia muito dinheiro e voltaria ao Brasil para comprar uma frota de caminhões, inspirado no caso de um ex-patrão dele que tinha ido para a Itália, comprou uns ônibus e ascendeu financeiramente.

Depois de dois meses em Portugal, ele pediu à Viviane que vendesse as ferramentas dele de mecânico e comprasse a passagem para ela e as duas 
crianças. Viviane nunca tinha saído do país e ido para um lugar tão longe. Levou poucas roupas e nenhum agasalho, pois não tinha ideia da temperatura local. $\mathrm{Na}$ ocasião já havia completado 24 anos, tinha muito medo dele e sabia, em parte, o que a esperava, pois vivia há muitos anos em situação de violência doméstica.

Isto explica o relato sem questionamentos e obediente à ordem de seu marido de vender algumas coisas da casa, enviar os móveis para a casa da mãe dele e ir com duas crianças pequenas e algumas mudas de roupa para um país distante.

Ficou um ano e meio sob a violência do marido e passando muitas dificuldades, chegando a pedir auxilio ao serviço social do colégio da filha para conseguir alimentos e roupas. O marido não a deixava sair de casa e nem trabalhar alegando ciúmes. Viviane e suas filhas viviam uma situação de violência doméstica, pois ele as agredia constantemente, física e psicologicamente.

Viviane conseguiu convencê-lo a deixá-la retornar com as filhas alegando que passavam muitas privações materiais e finalmente ele concordou. Conseguiu a passagem através da Organização Internacional para as Migrações. Ao chegar ao Brasil pediu a separação e tentou reconstituir sua vida.

A última entrevistada foi MICHELE, 38 anos, assistente social e moradora do Município de Duque de Caxias. Michele foi apresentada por outra assistente social que trabalha no município. Michele conheceu um cidadão português em uma das praias do litoral do Rio de Janeiro no Carnaval de 2008. Solteira, sem filhos e morando com os pais, ela relatou que ainda esperava encontrar um grande amor. E foi naquele Carnaval, quando tinha 35 anos, que aconteceu uma paixão a primeira vista por este português de 45 anos.

Ele ficou 10 dias no Brasil e depois de dois meses, conversando pelo skipe, ele mandou as passagens para ela conhecer a família dele em Portugal. Michele narrou que nunca havia imaginado em sair do país, mas como estava muito envolvida e gostando muito dele, decidiu ir. Ficou um mês e três dias, período que definiu como tendo uma vida de princesa. Em novembro daquele mesmo ano ele veio para conhecer a família dela e, ao retornar para Portugal, pediu para ela ir viver com ele.

Mesmo muito ligada à família, ela resolveu aceitar. Largou o emprego de 12 anos, vendeu o carro e fez algumas reformas na casa dos pais para que eles ficassem bem na ausência dela. Porém, neste período, enquanto se preparava para partir, ele começou a discutir com ela com mais frequência, mostrando um temperamento que ela ainda não conhecia, mais descontrolado e nervoso. 
Entre os motivos das discussões um deles foi porque ele não queria pagar a passagem de ida dela pois achava que com o dinheiro da demissão no trabalho, ao invés de fazer obra na casa dos pais, ela poderia custear sua própria passagem de ida. Outro motivo de discórdia foi porque ela comentou que pretendia ter filhos aos 40 anos e ele não queria mais filhos, pois já tinha um do primeiro casamento. E por fim, a última discussão foi quando ela indagou sobre a possibilidade dele enviar dinheiro para os pais dela até que ela arrumasse um emprego lá.

Apesar do sentimento de insegurança que estes episódios causaram nela, resolveu ir assim mesmo. Mas na semana que ela viajaria, ele telefonou desistindo , pedindo para ela não ir. O impacto desta decisão foi muito forte para ela, que não teve coragem de contar para a família e nem para ninguém que ele havia desistido. Sem emprego e desiludida, teve que recomeçar.

Três meses depois ele telefonou arrependido, mas ela estava muito magoada. Mesmo assim continuaram como amigos, até que em dezembro de 2009 ele veio novamente ao Brasil e a procurou. Michele não resistiu e se relacionou novamente com ele, se arrependendo depois. Esta foi a última vez que ficaram juntos, pois quando ele retornou a Portugal, ela pediu que não a procurasse mais. 
Quadro 3 - Síntese dos dados sociológicos das mulheres entrevistadas

\begin{tabular}{|c|c|c|c|c|c|c|c|c|c|c|c|c|}
\hline $\begin{array}{l}\text { NOME } \\
\text { FICTíCIO }\end{array}$ & $\begin{array}{l}\text { IDA- } \\
\text { DE } \\
\text { NA } \\
\text { EM- } \\
\text { TRE- } \\
\text { VIS- } \\
\text { TA }\end{array}$ & $\begin{array}{l}\text { IDADE } \\
\text { AO } \\
\text { EMI- } \\
\text { GRAR }\end{array}$ & $\begin{array}{l}\text { ANO } \\
\text { QUE } \\
\text { EMI- } \\
\text { GROU }\end{array}$ & $\begin{array}{l}\text { PAÍS } \\
\text { DE } \\
\text { DESTI- } \\
\text { NO }\end{array}$ & $\begin{array}{l}\text { MOTIVA- } \\
\text { ÇÃO PA- } \\
\text { RA } \\
\text { MIGRAR }\end{array}$ & $\begin{array}{l}\text { REDES SOCIAIS } \\
\text { NO PAÍS } \\
\text { DE } \\
\text { ORIGEM E } \\
\text { DESTINO }\end{array}$ & $\begin{array}{l}\text { FI- } \\
\text { LHOS }\end{array}$ & $\begin{array}{l}\text { ESCOLARI- } \\
\text { DADE }\end{array}$ & $\begin{array}{c}\text { ESTADO } \\
\text { CIVIL }\end{array}$ & $\begin{array}{l}\text { OCUPA- } \\
\text { ÇÃO }\end{array}$ & $\begin{array}{c}\text { QUEM A } \\
\text { AUXILIOU } \\
\text { NO PAÍS DE } \\
\text { DESTINO } \\
\text { E } \\
\text { DE ORIGEM }\end{array}$ & TRAJETÓRIA \\
\hline Geane & 41 & 30 & 1998 & $\begin{array}{c}\text { Espa- } \\
\text { nha }\end{array}$ & $\begin{array}{l}\text { Financei- } \\
\text { ra através } \\
\text { de } \\
\text { atividade } \\
\text { artística }\end{array}$ & $\begin{array}{l}\text { Laços de amizade } \\
\text { e vizinhança no } \\
\text { Brasil } \\
\text { Não tinha rede no } \\
\text { país de destino }\end{array}$ & Sim & $\begin{array}{c}\text { Fundamen- } \\
\text { tal } \\
\text { incompleto }\end{array}$ & Solteira & Diarista & $\begin{array}{c}\text { Clientes da } \\
\text { boate e hotel em } \\
\text { Espanha/ } \\
\text { Família da amiga } \\
\text { e } \\
\text { ONGs de } \\
\text { direitos } \\
\text { humanos no } \\
\text { Brasil }\end{array}$ & $\begin{array}{c}\text { Diarista } \\
\text { Dançarina/ } \\
\text { tráfico para } \\
\text { exploração } \\
\text { sexual } \\
\text { Diarista }\end{array}$ \\
\hline Patrícia & 35 & 23 & $\begin{array}{l}\text { Des- } \\
\text { de } \\
2000\end{array}$ & Itália & $\begin{array}{l}\text { Financeira } \\
\text { através } \\
\text { do } \\
\text { trabalho }\end{array}$ & $\begin{array}{l}\text { Laços familiares e } \\
\text { de amizade no } \\
\text { Brasil/ } \\
\text { Rede familiar e de } \\
\text { amizade no país } \\
\text { de destino }\end{array}$ & Não & $\begin{array}{l}\text { Ensino } \\
\text { médio } \\
\text { completo }\end{array}$ & Solteira & $\begin{array}{l}\text { Comerci- } \\
\text { ante } \\
\text { Camelô }\end{array}$ & $\begin{array}{c}\text { Noivo } \\
\text { estrangeiro }\end{array}$ & $\begin{array}{l}\text { Vendedora } \\
\text { de loja } \\
\text { Comerciante } \\
\text { autônoma }\end{array}$ \\
\hline Michele & 38 & 35 & 2008 & $\begin{array}{l}\text { Portu- } \\
\text { gal }\end{array}$ & Amor & $\begin{array}{c}\text { Laços } \\
\text { familiares no } \\
\text { Brasil e } \\
\text { nenhuma rede } \\
\text { no país de } \\
\text { destino }\end{array}$ & Não & $\begin{array}{l}\text { Gradua- } \\
\text { ção } \\
\text { completa }\end{array}$ & Solteira & $\begin{array}{l}\text { Assisten- } \\
\text { te } \\
\text { Social }\end{array}$ & $\begin{array}{c}\text { Família } \\
\text { no Brasil e } \\
\text { namorado } \\
\text { estrangeiro } \\
\text { que } \\
\text { conheceu } \\
\text { no Brasil }\end{array}$ & $\begin{array}{l}\text { Assistente } \\
\text { Social }\end{array}$ \\
\hline Viviane & 29 & 24 & 2007 & $\begin{array}{l}\text { Portu- } \\
\text { gal }\end{array}$ & $\begin{array}{l}\text { Reunifi- } \\
\text { cação } \\
\text { familiar }\end{array}$ & $\begin{array}{c}\text { Laços } \\
\text { familiares, } \\
\text { mas } \\
\text { isolamento } \\
\text { devido à } \\
\text { violência } \\
\text { doméstica no } \\
\text { Brasil } \\
\text { Nenhuma } \\
\text { rede de apoio } \\
\text { no país de } \\
\text { destino }\end{array}$ & Sim & $\begin{array}{l}\text { Fundamen- } \\
\text { tal } \\
\text { incompleto }\end{array}$ & $\begin{array}{c}\text { União } \\
\text { estável }\end{array}$ & Do Lar & $\begin{array}{c}\text { OIM } \\
\text { em } \\
\text { Portugal/ON } \\
\text { G de } \\
\text { direitos } \\
\text { humanos e } \\
\text { parentes no } \\
\text { Brasil }\end{array}$ & Do Lar \\
\hline Luiza & 49 & $\begin{array}{l}14 \\
26 \\
30\end{array}$ & $\begin{array}{l}1976 \\
1988 \\
1992\end{array}$ & $\begin{array}{l}\begin{array}{l}\text { Portu- } \\
\text { gal }\end{array} \\
\text { Portu- } \\
\text { gal } \\
\text { Itália } \\
\text { Portu- } \\
\text { gal }\end{array}$ & $\begin{array}{c}\text { Financeira } \\
\text { para } \\
\text { exercer } \\
\text { atividade } \\
\text { artística e } \\
\text { busca de } \\
\text { status }\end{array}$ & $\begin{array}{c}\text { Laços de } \\
\text { amizade no } \\
\text { Brasil e } \\
\text { nenhuma rede } \\
\text { de apoio no } \\
\text { país de destino }\end{array}$ & Sim & $\begin{array}{c}\text { Fundame } \\
\text { ntal } \\
\text { incomple } \\
\text { to }\end{array}$ & Solteira & $\begin{array}{l}\text { Profissio- } \\
\text { nal do } \\
\text { sexo }\end{array}$ & Igreja & $\begin{array}{c}\text { Dançarina/ } \\
\text { Mulata } \\
\text { profissional/ } \\
\text { tráfico para } \\
\text { fins sexuais/ } \\
\text { Profissional } \\
\text { do sexo }\end{array}$ \\
\hline
\end{tabular}




\title{
5.3 \\ A motivação para migrar
}

Para Ariza ( 2000) a migração tem como característica não ser um evento a mais no decurso da vida, mas uma transição, que, junto com outras transições e trajetórias, outorga sentido à historia de vida individual.

Neste sentido a narrativa das mulheres entrevistadas, começa com o relato da motivação para emigrar.

De acordo com Ofélia Woo Morales (2007),

\begin{abstract}
Algumas teorias migratórias têm tratado de explicar que a decisão de migrar está relacionada à lei da oferta e da procura do mercado de trabalho como fatores de atração e expulsão (push-pull); as estratégias familiares em uma relação de custo-benefício (Nova Economia) ou as redes sociais, sendo elas fortes ou fracas, desempenham um papel importante na migração. Estas teorias migratórias nos ajudam a conhecer alguns aspectos que incidem na tomada de decisão (estruturais e familiares), no entanto, não explicam como as relações de gênero e geração tem incidência para que mulheres emigrem ou permaneçam (p.26).
\end{abstract}

Acredita-se que representação e o significado da experiência migratória para mulheres e homens apresentam diferenças influenciadas pela condição de gênero, baseada na construção social de papéis sociais assimétricos a que são submetidos em seus processos de socialização nas diferentes culturas.

Isso explica porque tradicionalmente nos estudos sobre migração, ao se falar em projetos migratórios, estes se referem a projetos masculinos e não femininos, pois se reproduz a construção destas assimetrias, o que não significa que a mulher não possa ser protagonista de processos migratórios, podendo vir a subverter, questionar e reconstruir este lugar de subalternidade reservado a ela.

Neste sentido que a relação de gênero e a forma como esta são vivenciadas pelas mulheres em suas trajetórias individuais, vão influir também no processo migratório. Assim, a decisão de emigrar pode expressar tanto uma maior autonomia quanto a subordinação desta mulher em relação a sua posição na família, na vida e nas condições estruturais de sua sociedade.

As mulheres entrevistadas, como já mencionado, migraram quando tinham idade entre 14 e 35 anos e a partir da década de 1970, período de grande crise mundial com a imposição pelos países de capitalismo central de 
ajustes econômicos e estruturais em países de capitalismo periférico, sob a égide do neoliberalismo.

Este é um período de agravamento das desigualdades econômicas e sociais, através da reestruturação da produção, o que irá gerar uma desregulamentação e precarização das relações de trabalho, aumento do desemprego em massa, além da redução da ação do Estado no mercado e na garantia de políticas sociais.

Nos anos 80 e 90, o aumento dos fluxos de emigrantes brasileiros para o Japão, Estados Unidos e Europa, evidenciam as estratégias de sobrevivência deste período.

Das mulheres entrevistadas apenas Michele tinha emprego estável, em um órgão público como assistente social. Geane, Patrícia e Luíza viviam de empregos informais e precários e somente Viviane não trabalhava fora de casa. Através destas inserções, formais e informais no mercado de trabalho, estas mulheres desempenhavam um importante papel de sustento e apoio de suas famílias quando ainda estavam no Brasil. Três delas continuaram a desempenhar tais papéis após a migração.

Eu não tenho filhos, mas tenho um pai acamado, eu moro com meus pais, meu pai está acamado, já tem cinco anos, e quem arca com as despesas de medicamentos, de acompanhamento, de médico, tudo isso fica por minha conta. Minha mãe tem problema de coluna, faz tratamento com neurocirurgião e toma um medicamento controlado. Tenho sete irmãos: cinco do primeiro casamento do meu pai, uma irmã do primeiro casamento da minha mãe, e um casal (eu e meu irmão), do casamento do meu pai com a minha mãe. Meu irmão mora em $S P$, e meus outros irmãos a maioria mora aqui, meu pai deixou todo mundo com uma casinha numa parte do quintal onde eles foram construindo as suas casas. Eu fico muito presa pelo fato de meu pai, e não abro mão de estar ajudando a minha mãe, isto me prende um pouco porque eu sou muito ligada à família. (Michele).

O salário da Itália é 1.200 euros, você ganha um salário bom, paga um aluguel de 500 euros... Ganha mais, gasta mais, porque tudo lá custa mais, o mercado custa mais, o condomínio custa mais. Na verdade, para juntar um dinheiro é muito difícil. Não é que você vai para a Itália, para Alemanha, onde quer que você vai, vai trabalhar e vai ficar rica, não vai, porque tem seus gastos ali, tem família para ajudar, geralmente. No meu caso eu tenho minha mãe para ajudar, que não tem uma pensão. É complicado. (Patrícia).

Mesmo Viviane que não trabalhava fora, mantinha e administrava o orçamento da casa, principalmente quando o ex-marido estava fora nos EUA e depois em Portugal. Eles viviam em Vitória, no Espírito Santo, mas todas as vezes que ele decidia emigrar a enviava para a casa da mãe dele em Minas 
Gerais. Provavelmente essa seria uma forma não só de ajudar a esposa com as crianças, mas de controlá-la visto o ciúme que ele sentia, conforme foi narrado.

Viviane relatou que sempre sofreu em silêncio a violência cometida por seu parceiro íntimo. O medo, a dependência econômica, o isolamento de sua família, a vergonha foram alguns fatores que contribuíram para que permanecesse suportando esta situação por alguns anos.

A Convenção Interamericana para Prevenir, Punir e Erradicar a Violência Contra a Mulher - Convenção de Belém do Pará (1994) e ratificada pelo Brasil em 1995, definiu a violência doméstica contra a mulher como qualquer ato ou conduta baseada no gênero, que cause morte, dano ou sofrimento de natureza física, sexual ou psicológica à mulher tanto na esfera pública como na esfera privada.

Desde 2006 o Brasil criou uma lei especifica que tipifica como crime e pune a violência doméstica contra a mulher, a Lei Maria da Penha que define este tipo de violência como sendo qualquer ação ou omissão baseada no gênero que cause morte, lesão, sofrimento físico, sexual, psicológico, dano moral ou patrimonial e perpetrada por pessoa com quem possua vínculo de afeto.

A situação de violência vivenciada por Viviane antes de migrar foi determinante quando da sua saída do país, caracterizando uma situação de coação para migrar, tendo em vista a sua subordinação imposta pela violência de gênero.

Luiza, Geane, Michele e Viviane não planejavam em sair do país antes de surgir aquela oportunidade, porque parecia uma perspectiva muito longe da realidade em que viviam. Elas não possuíam no país de destino uma rede social de parentesco ou amizade, o que contribuiu para que não permanecessem mais do que um ano e meio no país de destino, devido às dificuldades enfrentadas.

Michele possui uma rede social forte aqui no Brasil, o que não acontecia com Geane, Luzia e Viviane, cujas redes sociais eram mais fragilizadas, e no caso específico de Geane e Luzia, a rede que Ihes dava apoio foi a mesma que as aliciou para o tráfico, o que prejudicou a análise por parte delas dos riscos que poderiam correr e confiando plenamente nestas pessoas.

Patrícia planejou sua saída e tinha redes sociais estabelecidas parentes e amigos -tanto aqui no Brasil como no país de destino. É interessante destacar que ela foi a que teve maior tempo de permanência no país de destino em comparação com as outras mulheres, o que corrobora para afirmar a importância das redes sociais nos processos migratórios. 
Assis e Siqueira (2009) são autoras que ressaltam a importância das redes sociais no processo migratório, particularmente as redes de parentesco, amizade e origem comum, sobretudo no caso de migração de longa distância. Afirmam as autoras, quanto mais estabelecidas estas redes, maiores chances tem o migrante no local de destino, constituindo-se num capital social e cultural muito importante para a inclusão em outro lugar.

As redes no país de origem são relevantes também quando a mulher tem filhos que não vão emigrar com ela, a permanência e o cuidado destes por parentes ou amigas, será um determinante na decisão de migrar.

Eu agradeço muito a ela, que ela foi uma pessoa muito boa para mim, a mãe dela, o pai dela, como até hoje eu o chamo de pai, que eles me tratam muito bem. Quando eu estava na Espanha, tinha deixado meu filho mais velho, de 7 anos, com a mãe da Marcela. Com a confusão que aconteceu na Espanha eu pedi a mãe de Tatiane para pegar meu filho com a mãe da Marcela. E meu filho ficou com os pais da Tatiane. (Geane)

Fui mãe com 22 anos e o meu filho ficou com minha sogra. E pensei, o que eu sei fazer? Sei sambar e fui mostrar o que sabia fazer. (Luiza).

Para Geane viajar, a mãe da aliciadora ficou cuidando de seu filho, no entanto a amizade com Tatiane, que conheceu na viagem, e posteriormente com a família dela, que auxiliou no retorno das duas para o Brasil, possibilitou a criação de laços de amizade que fez com que o filho de Geane passasse a ser cuidado pelos pais de Tatiane.

A situação de Luiza foi um pouco diferente: ela deixou o filho com a sogra, o que possibilitou a sua segunda viajem para o exterior. Porém, seu envolvimento com as drogas, ocasionou o afastamento de seu filho.

Eu só tenho um filho e ele não compreendeu, porque ficou muitas sequelas do uso de drogas, eu acabei realmente me viciando e depois eu sumi. Para você parar tem que fazer o ambiente se não você não consegue (Luiza).

Outro aspecto relevante do papel das redes é no auxilio ao financiamento da migração. Algumas das entrevistadas narraram que receberam auxilio de parentes, de amigas, de namorados que eram cidadãos do país de destino, de donos de boates e casas de shows. Provavelmente, sem esses apoios, ou não teriam emigrado ou demorariam mais tempo para fazê-lo. 
Alberto veio, tirou nossos passaportes. Ela andou com ele para cima e para baixo. Tirou os vistos, umas papeladas para a gente assinar, tomar vacina. Tudo certo. (Geane).

Nunca tinha saído do país, não imaginava em conhecer a Europa, para mim era tudo novo, eu nunca tive essa vontade de conhecer outro país. São coisas que não enchem os meus olhos. Porque primeiro eu penso em conhecer o Brasil, para depois conhecer algum lugar lá fora. Mas assim, pintou a oportunidade e eu agarrei. (Michele).

As redes sociais de parentesco e amizade são principalmente importantes quando a pessoa que migra para longa distância não tem o conhecimento da língua do país de destino, tem poucos recursos, baixo nível de escolaridade e pouca experiência profissional.

$\mathrm{Na}$ ausência das referidas redes, migrantes nas condições descritas encontram grandes dificuldades de ingresso em diversos países, optando pelo auxílio de contrabandistas para a entrada irregular, o que não Ihes garante a integridade física nem a chegada ao país de destino, pois podem vir a se envolver em graus elevados de exploração econômica, ou mesmo, abuso e violência física, o que caracterizaria o tráfico de pessoas ${ }^{47}$.

Cabe lembramos que o contrabando caracteriza-se como crime contra o Estado, colocando aquele que se favorece deste tipo de auxilio ilegal como cúmplice e criminoso.

Mesmo para aqueles imigrantes regulares, a ausência de rede social no país de destino dificulta a permanência, uma vez que não tem quem possa recebê-los e lhes arrumar emprego, estando expostos as situações piores do que viviam em seu país de origem, que podem também envolver violência e exploração.

Foi o caso de Geane e Luiza, que foram vítimas de tráfico, apesar de entrarem regularmente. $\mathrm{E}$ de Viviane, que sofreu muito com a violência doméstica e a pobreza antes de conseguir o apoio de alguma instituição.

A teoria da Análise de Redes Sociais presente nos estudos migratórios, será examinada a fim de trazer à reflexão os determinantes que conferirão aos fluxos migratórios, estabilidade e continuidade, bem como a adaptação dos migrantes à sociedade de destino.

\footnotetext{
${ }^{47}$ Lembrando, com base no Protocolo de Palermo, são elementos que caracterizam o tráfico: a) Ato: Recrutamento, transporte, transferência, alojamento ou o acolhimento de pessoas; b) Meio: Ameaça ou uso da força, coerção, abdução, fraude, engano, abuso de poder ou de vulnerabilidade, ou pagamentos ou benefícios em troca do controle da vida da vítima; c) Finalidade: para fins de exploração, que inclui prostituição, exploração sexual, trabalhos forçados, escravidão, remoção de órgãos e práticas semelhantes (UNODC).
} 
De acordo com esta concepção o fator que mais leva o indivíduo a migrar é a proximidade das relações sociais, isto é, vai seguindo as rotas traçadas antes dele por parentes e amigos (Durham, 1984). Foi justamente o que foi observado também nos relatos recolhidos: as entrevistadas migraram para países a partir da indicação e apoio de pessoas conhecidas. O destino não foi propriamente escolhido por elas, mas influenciado pelas relações estabelecidas com amigos, conhecidos, maridos, noivos, pessoas em quem depositavam certa confiança.

A oportunidade de migrar surgiu para todas as entrevistadas a partir do convite de pessoas do seu relacionamento ou mediadas por elas, o que reforça a afirmação de Durham (1984).

O fato de serem pessoas do convívio destas mulheres como amigas, parentes, colegas de trabalho e empregadores, parece ter proporcionado a estas, de acordo com seus relatos, uma sensação de maior segurança e incentivo para migrar.

Na verdade foi uma oportunidade, pois minha irmã morava lá em Milão, minha irmã já estava lá há bastante tempo, trabalhando com limpeza, ela trabalhou vários anos prestando serviço para um hospital. Apesar de eu não gostar de fazer limpeza, eu comecei e o clima foi muito difícil para mim, pois eu não me adapto ao inverno. Então eu preferi voltar para o Brasil e voltar a fazer o que eu sempre fiz que era trabalhar com moda e comecei a trabalhar nesta empresa $X$, prestando serviço para eles, bordando as sandálias e foi quando surgiu a oportunidade de trabalhar lá com eles, sendo que eles me prometeram que iriam fazer o meu documento, já tive experiência de dois anos de Itália e sabia como funcionava (...)Eu comecei a trabalhar com 14 anos de idade, só trabalhando, não tive filhos, não casei, só pensei o tempo inteiro nisto ai, de trabalhar, de juntar um dinheiro, de vencer na vida. (Patrícia).

Ele conheceu um colega, da outra firma que ele foi trabalhar que é a Piraquê, fábrica de pão, que ele fazia transporte de Jacaraíbe para Niterói/São Gonçalo. Conheceu um colega que os pais moravam em Portugal. Então ele falou que iria para lá junto com este amigo dele. Eu perguntei: será que vai dar certo? O fulano falou que eu fico um tempo na casa dele, até eu melhorar minha vida. Então ele foi embora com a cara e a coragem, comprou a passagem e foi para Portugal. Depois de dois meses pediu para eu vender umas ferramentas que ele adquiriu quando foi para os EUA, porque ele era mecânico também, pediu para vender para o ex-patrão dele, as ferramentas todas, para comprar as passagem e ir embora com as meninas. (Viviane).

Eu morava dentro da casa de Marcela, com a mãe dela (que hoje em dia já faleceu) e com as irmãs dela. Ela sempre ligava e dizia que estava muito bem e que quando chegasse ao Brasil ia montar um grupo e levar para a Espanha, que estava aprendendo o esquema de tudo. Nisso eu continuava aqui trabalhando (...) Um dia ela disse que a gente tinha que estar preparado, que o Alberto estava vindo ao Brasil. Que era o amante dela, esse safado desse Alberto estava vindo ao Brasil e ia trazer a documentação, o passaporte, o visto e tudo certinho para a viagem. Ele está vindo para comprar o resto das roupas, que cada dança a gente fazia um quadro. Eu dançava Carmem Miranda, fazia abertura do Samba, dançava lambada, dançava maculelê, axé, samba, capoeira. 
Eu estava com 29 anos e já tinha meus dois filhos. Quando eu cheguei na Espanha eu completei 31 anos, em agosto. A única de menor do grupo era a Tatiane, ela tinha 17 para 18 anos e a filha da Marcela. (...). Ela primeiro fez a apresentação aqui para todo mundo ver que não era uma coisa enganada. Um dia antes do show a gente já estava com as passagens na mão para viajar. (...)A Tatiane não queria ir, mas a mãe dela disse para ela ir que poderia ser uma coisa boa para ela. Todo mundo quer ter um sonho na vida. (Geane).

Geane decidiu viajar a partir do convite de uma amiga, quase irmã, para compor o grupo de dança que esta havia organizado e que era constituído por mulheres e homens, que na sua maioria já eram conhecidos seus, pois frequentavam a mesma Escola de Samba, sendo alguns vizinhos do bairro.

Luiza migrou a primeira vez motivada pela ideia que surgiu com o padrinho, bicheiro e fundador da Escola de Samba, de organizar um grupo para apresentar no exterior show sobre o Carnaval. Durante a entrevista o mencionou como sendo um pai e protetor.

Outras viagens que Luiza fez ao exterior parecem ter sido promovidas por pessoas que não eram do seu convívio direto, mas faziam parte do seu ramo de atividade, em boates e casas de show, onde ela se apresentava como sambista. As informações de oportunidades de contratação para os shows às vezes eram trazidas por meio de amigas, habituadas a fazer shows no exterior e que trabalhavam e conviviam com ela.

Teresa Kleba Lisboa (2007), em seu artigo "Fluxos migratórios de mulheres para o trabalho reprodutivo", traz uma síntese da pesquisa realizada por ela com mulheres que emigraram de países periféricos (mais especificamente peruanas, filipinas e indonésias) para trabalhar na Europa, com o objetivo de conhecer os motivos da ida e suas atuais condições de trabalho. A autora ressalta os principais motivos da emigração que são apontados pelas mulheres (p.810):

1) A questão socioeconômica: falta de oportunidades de emprego ou ocupações remuneradas no país de origem, bem com a desvalorização do trabalho feminino;

2) O acesso à educação ou a oportunidades de maior qualificação profissional;

3) A conquista da independência econômica e social de suas famílias de origem, principalmente as solteiras, viúvas ou mulheres que sofriam violência no local de origem;

4) A possibilidade de alcançar mobilidade social, melhorar de status em relação ao emprego que exerciam nos países de origem, ou seja, serem valorizadas;

5) O acesso a serviços básicos, atendimento à saúde;

6) Experimentar diferentes sensações: conhecer um país diferente, divertir-se, ir as festas, sair com amigas, aprender coisas novas; 
7) Ir atrás da rede familiar de conhecidos ou amigos que já se encontram no país e motivam a emigração.

A motivação para migrar apontada pelas entrevistadas dessa pesquisa foi das mais variadas, entretanto não difere muito daquelas apontadas por Teresa Kleba Lisboa.

Patrícia migrou por questão econômica atrás de melhores oportunidades de trabalho; Michele migrou motivada pela paixão, a princípio a passeio para conhecer Portugal e a família do seu amado, mas posteriormente iria migrar para casar com ele; Geane pela possibilidade de altos ganhos almejando a independência econômica e social; Luiza migrou almejando ser famosa com seu trabalho de dançarina e ganhar muito dinheiro e; Viviane migrou a pedido de marido que já estava no exterior, a chamada reunificação familiar.

\begin{abstract}
Não era uma coisa que eu desejava, mas é uma coisa que toda pessoa quer mostrar o seu país, a sua gente, como o Brasil é índio, português e africano para os americanos, espanhóis. Na época eu e minhas primas, éramos umas 16 meninas e eu era afilhada mesmo do falecido bicheiro fundador da Escola. Eu morava no bairro e então a gente vivia ali dentro do samba, então ia muita gente lá para ver o carnaval. O Carnaval há trinta e cinco anos atrás não era igual agora. E sabia que vinha turista e o Brasil tinha mais dinheiro por causa do turismo e do Carnaval. Eu nasci no berço desta Escola de Samba. Então quando começou esta divulgação para o exterior, o padrinho pensou em fazer um show para o exterior com as meninas de Nova Iguaçu e da Baixada (...) na primeira vez eu pensei em dinheiro e voltar famosa. (Luiza).
\end{abstract}

Quando eu fui para trabalhar com as sandálias eu fui para trabalhar na loja delas. Minha expectativa primeiramente foi o salário e de mudar de vida, de sair do bairro onde eu morava, que eu odiava morar em São Gonçalo. Sem dúvida foi uma expectativa, pois eu já fui uma vez e não consegui. Insisti porque desta vez eu tinha uma coisa mais certa, um trabalho mais certo, eles iam me colocar in regula. (Patrícia).

E ai foi aquela paixão toda, dois meses depois ele mandou as passagens para que eu fosse a passeio conhecer a família dele. Nunca tinha saído do país. Mas assim, pintou a oportunidade e eu agarrei. Porque eu estava me envolvendo com uma pessoa que eu gostava, eu estava super envolvida e meti as caras. (Michele).

Eu fui mais porque eu queria ter uma casa própria e juntar um dinheiro. A gente ia para ficar nove meses lá. Eu queria juntar meu dinheiro e comprar uma casa própria, não vou dizer que seria um casarão, mas um barraquinho, nem que eu levantasse aos poucos, mas seria meu. (Geane).

As narrativas mostram o desejo das mulheres em mudar as suas condições de vida, de alcançar uma independência econômica ou de encontrar o "príncipe encantado". Motivações que parecem, por um lado, subverter a condição de gênero através da busca de uma maior autonomia e independência 
e, por outro, reforçar esta condição, através da inserção em situações que recolocam sua dependência e submissão.

A motivação inicial destas mulheres em migrarem, muitas vezes não corresponde à realidade que elas vão encontrar ao chegar ao país de destino.

As histórias de Luiza e Geane possuem alguns aspectos em comum, apesar de nunca terem se conhecido, ambas foram vítimas de tráfico de mulheres. Suas histórias levam a refletir sobre os fatores que contribuíram para que tal fato ocorresse.

Luiza e Geane viviam em situações de precariedade no trabalho, possuíam baixa escolaridade e nenhuma qualificação profissional, além de apresentarem certa fragilidade dos vínculos familiares e de amizade.

Eu não tinha família, eu era tutelada por uma irmã de meu pai biológico, mas eu era uma mucama. Era ela, o marido dela, que era da marinha e os dois filhos. Ela era muito ligada à Escola de Samba, era costureira da ala das baianas e eu sempre vivi neste vinculo de samba. O meu primeiro aborto foi do meu próprio tio que me estuprou. (Luiza).

Geane contou-nos que tem dois filhos e que morava com um deles na casa da amiga que a levou para a Espanha.

Assim como a maioria das mulheres entrevistadas, elas não tinham o domínio da língua do país de destino e tampouco informações sobre este. Foram convidadas por pessoas conhecidas e que faziam parte de suas relações pessoais ou de trabalho.

Geane e Luiza receberam propostas para trabalhar como dançarinas em outro país, com a passagem e estadia pagas e documentos legalizados. Mas chegando ao destino, não encontraram aquilo que haviam lhes prometido.

Quando Marcela chegou ao Brasil, ela veio sozinha, o grupo da Escola de Samba já tinha vindo antes e ela estava com esse espanhol. Ele tinha duas casas de prostituição na Espanha e ela não foi enganada por ele, ela já sabia de tudo. Quem foi enganada foi a gente aqui. Ela veio da Espanha e falou que ia montar um grupo e ia me colocar e dizia: "você não vai mais precisar trabalhar mais em casa de família, não vai precisar ralar mais, acordar cedo às 05 horas da manhã". Ela colocou eu e a irmã dela e ia arrumar umas meninas que tinham que ser altas, bonitas, ter corpo, isso tudo. Marcela alugou uma quadra perto da casa dela para ensaiar todo tipo de dança, todo dia. (Geane).

A coisa começou a mudar quando começamos a receber propostas de donos boates do Rio e de São Paulo, em 2002. Foi quando eu sai novamente, com 26 anos. Eu já estava morando em Cabuçu, quando eu recebi uma proposta. Fizeram uma proposta enganosa ao pessoal, você vai, nós te damos passagem e estadia você vai dançar (Luiza). 
As histórias delas contrariam a associação exclusiva do tráfico de pessoas com a migração irregular e ao contrabando, justificativa utilizada para o controle restritivo das fronteiras por alguns países. Pelo menos em relação à saída do país de origem, ambas migraram de forma regular, apesar de não levarem em consideração os riscos que corriam.

É importante ressaltar que neste primeiro momento, de acordo com o relato de ambas, sem qualquer conhecimento sobre a existência de ação de aliciadores para o tráfico de pessoas, elas não tinham como saber que se tratava de uma proposta enganosa. Este conhecimento e identificação da situação vivida como tráfico virá após o retorno ao Brasil e, com a responsabilização judicial dos aliciadores ou transcorrido mais tempo, com o acesso às informações sobre este tema. Isso não significa, não obstante, que não tenham considerado como violenta a situação que vivenciaram.

A história de Viviane se destaca das demais, e, traz um diferencial, pois envolve alguns elementos que poderiam caracterizá-la como tráfico de mulheres, porém não se trata de um caso de tráfico, mas, fornece elementos fundamentais que fomentam o debate desta questão.

De acordo com o Protocolo de Palermo, o tráfico de pessoas envolve: "o recrutamento, o transporte, a transferência, o alojamento ou recolha de pessoas; a ameaça de recurso à força ou pelo recurso à força ou a outras formas de coação, o abuso de autoridade ou de uma situação de vulnerabilidade; com a finalidade de exploração. A exploração, de acordo com esse documento, incluirá, no mínimo, a exploração da prostituição de outrem ou outras formas de exploração sexual, o trabalho ou serviços forçados, escravatura ou práticas similares à escravatura, a servidão ou a remoção de órgãos".

Estas conceituações trazidas pelo Protocolo de Palermo são alvos de críticas, pela imprecisão de alguns termos utilizados, tais como "abuso de poder", "de uma posição de vulnerabilidade", "para fins de exploração", "servidão" ou "outras formas de coerção".

No caso de Viviane, o deslocamento mediante a coação para viajar por ameaça de recurso à força; formas de coerção e a condição de servidão, imposta pela violência física e psicológica, através do espancamento, da humilhação, da desqualificação e do cárcere privado, deixa dúvidas se este seria um caso de tráfico. Entretanto trata-se de um caso de violência doméstica contra a mulher, reconhecido por Viviane como tal. 
Esse é um caso que evidencia estas imprecisões, pois seria o caso de Viviane considerado um exemplo de exploração ou de servidão? A finalidade comercial teria que estar presente na situação para caracterizá-la como tráfico?

Mesmo havendo a maioria dos elementos que constituiriam o tráfico, não há, no entanto, a finalidade de obtenção de lucros, um caráter mercantil.

Mesmo Viviane sabendo plenamente os riscos que corria, pois havia um histórico de violência doméstica recorrente, ela decidiu se arriscar. Pela própria dinâmica deste tipo de violência de gênero, que envolve relações de afeto, dependência e medo, verifica-se que Viviane foi coagida pelo marido a viajar ao encontro dele.

Nesse aspecto, cabe destacar que nos estudos migratórios, carece de uma reflexão que aborde a violência doméstica como fator que possa contribuir para a decisão de migrar.

Numa abordagem mais ampla, Carlos Vainer afirma, em relação aos deslocamentos compulsórios, que estes interrogam as teorias migratórias sobre o lugar e o papel da coação e da violência na mobilização e imobilização das populações.

Os deslocamentos compulsórios são situações ocasionadas pela violência das guerras; além de outras situações que forçam o deslocamento, como desastres ou grandes interferências ambientais por parte do ser humano e que obrigam o deslocamento de populações sem a vontade destas. Para este autor os deslocamentos compulsórios constituem um ponto cego nas teorias das migrações.

Nesta reflexão pode-se incluir o deslocamento de mulheres que, fugindo de situações de opressão e violência, buscam novas oportunidades de refazerem suas vidas em outros lugares, distantes destas situações.

No entanto se a migração feminina ainda tem pouca visibilidade nos estudos migratórios, o que dirá a abordagem de gênero e violência na análise dos deslocamentos de mulheres, que tanto pode ser a causa da decisão de migrar ou consequência desta, quando estas mulheres são submetidas à ação de criminosos envolvidos com a migração irregular e o trafico de mulheres.

Para Vainer o reconhecimento da violência como fato migratório, depende da introdução no campo dos estudos migratórios de um conjunto de processos de deslocamento de populações que têm como elemento central e dominante o exercício do poder. 


\section{4 \\ A permanência no país de destino}

Patrícia e Viviane emigraram entre os anos 2007 e 2008, mesmo que não tenham sofrido nenhum tipo de restrição na entrada nos países para os quais migraram, seus deslocamentos se dão num período de grande crise econômica mundial que as inserem num contexto de insegurança e de poucas perspectivas de conseguirem mudar as condições de precarização já vivenciadas no país de origem.

Patrícia foi a que permaneceu mais tempo no país de destino. Ela continua se deslocando entre Brasil e Itália desde o ano 2000.

O apoio das redes sociais de parentesco ou amizade ou outros relacionamentos no país de destino pareceu determinante para permanência de Patrícia por um tempo mais longo. O que não significa que não tenha enfrentado dificuldades.

Todas narraram - com exceção de Michele que ficou bem pouco tempoque passaram por dificuldades mais diversas, desde aquelas ligadas às condições materiais de existência até dificuldades de cunho subjetivo que envolve a adaptação em um país de cultura e língua diferentes, onde elas eram vistas como estrangeiras.

Outro aspecto trazido por Patrícia - que emigrou para melhorar suas condições de vida através do trabalho - foi a da precarização e da exploração do trabalho a que ficou submetida, como doméstica e posteriormente como vendedora.

A falta de comprometimento dos patrões em relação à regularização de papéis, documentos legais ou visto de permanência, o não pagamento de horas extras, a sobrecarga de trabalho, a ausência de direitos trabalhistas e a violência e o abuso sexual, são algumas das violações que sofrem a mulher migrante indocumentada ou irregular no país de destino, como relatou Patrícia em dois momentos diferentes.

Os relatos de Patrícia exemplificam a linha tênue que separa a classificação de uma situação como tráfico ou não. Os relatos de engano, falsas promessas por parte dos patrões que a fizeram se deslocar, o trabalho precário e explorado poderiam caracterizar o tráfico de pessoas. Mas, as formas de exploração, segundo o Protocolo de Palermo, podem se dar por meio da 
exploração da prostituição de outrem ou outras formas de exploração sexual, de trabalhos ou serviços forçados, da escravatura ou práticas similares à escravatura, da servidão ou para a remoção de órgãos. Alguns aspectos do relato de Patrícia, no entanto, não se enquadram nesta classificação, pois não chegou a ser escravidão ou servidão, mas um trabalho explorado dentro dos moldes de uma sociedade capitalista contemporânea.

Então eles me prometeram em fazer este documento e isto não aconteceu. Foi uma fraude para mim, pois eu larguei tudo, apesar de ser um momento de mudança para mim. (...) quando eu fui para trabalhar com as sandálias eu fui para trabalhar na loja delas. Minha expectativa primeiramente foi o salário e de mudar de vida, de sair do bairro onde morava que eu odiava morar em São Gonçalo. Sem dúvida foi uma expectativa, pois eu já fui uma fez e não consegui. Insisti porque desta vez eu tinha uma coisa mais certa, um trabalho mais certo, eles iam me colocar in regula. $E$ na verdade não aconteceu. $E$ a proposta veio deles. Eu trabalhei vendendo e eu sei vender bem e já falava o italiano. Eles me pagavam bem. Me deram casa, me davam alimentação. $O$ horário era muito pesado a fabrica fechava às 19 horas, só que a dona da empresa levava os biquínis para fazer acabamento e botar a etiqueta em casa. Eu como estava ali, na casa desta senhora, o que eu fazia? Trabalhava até as 23:00h, 24:00 h. Nisto eu fiquei quase um ano lá. E vi que a oportunidade não existia e esse documento nunca iria sair e eu precisava do documento. Eu via que eu já não queria mais. Eu ajudei bastante eles, em falar português, tudo no computador eu fazia para eles. Então eles aproveitaram. (Patrícia).

Patrícia que já sentiu "na pele" o que é estar irregular consegue traduzir em poucas palavras que estar sem documentos significa não ser ninguém, não ter direitos.

O estrangeiro não é encarado como um ser humano lá, quanto maior o poder aquisitivo desta família [referindo-se ao trabalho doméstico], mais você será visto como um nada. São vistos como estranhos, e se trabalhar na casa de judeu... Eu já trabalhei na casa de uma senhora judia e ela judiava mesmo da gente. $O$ marido dela tacava o jornal na cara da minha irmã e ele abusava de uma filha da funcionária das Filipinas, menor de idade, passava a mão nela. Eu, no lugar da mãe eu denunciaria ele, porque ele tem nome, mas sabe como é que é né!!?? Os filipinos já entram com documentos, mas com medo de perder o trabalho, as pessoas têm que infelizmente a passar por isto ai. Já aconteceu também deu estar limpando uma casa e um senhor, quase morrendo, deitado com problema de coração, passou a mão no meu seio. Você passa por estas coisas ainda mais se souberem que você não tem permesso di soggiorno, você não é nada! $O$ cachorro dele tem permesso, você não tem, então quer dizer, eles vão te pagar menos, vão fazer você trabalhar mais. (Patrícia).

De acordo com Patrícia ser mulher migrante e irregular, faz com que não se tenha os direitos reconhecidos, tornando-se em alguns momentos, alvo de 
assédios e abusos por parte dos patrões, conforme relatado por ela sobre quando desenvolvia trabalho no espaço doméstico.

Lisboa (2007), analisando a inserção de mulheres migrantes como trabalhadoras domésticas na sociedade de destino, conclui que,

Patrões e empregadas domésticas, em geral, participam de uma relação de identidade mediada pela lógica da servidão: para os patrões servir é algo natural, configurando uma relação de exploração e iniquidade. A servidão implícita no trabalho das domésticas faz parte de uma ideologia que cristaliza essa atividade como ultraconservadora em uma sociedade profundamente hierarquizada. A função ideológica dessa ocupação - trabalhadora doméstica - baseada em rituais de diferença e maternalismo vem perpetuar um sistema de estratificação social que articula necessariamente as categorias "gênero", "classe" e "etnia". (Lisboa, 2007, p.815).

Segundo Dal Lago (apud Ausserer, 2007) os migrantes não documentados são desqualificados, como "não pessoas", pois o conceito de pessoa depende de uma humanidade atribuída.

O fato que as categorias atribuídas ao migrante "ilegal" sejam caracterizadas em termos de negação representa uma forma de despersonalização; o migrante é um não- europeu, um não-nativo, um não cidadão, não esta em regra e não faz parte de nós. Além da negação de direitos, então, o othering puxado aos extremos, leva a desqualificação dos migrantes da categoria de pessoas. Neste sentido a classificação dos migrantes "ilegais" como outros ou como além do humano, justifica mecanismos de exclusão, como também práticas de violência. (Dal Lago apud Ausserer, 2007, p. 139-140).

Uma das estratégias assumida por Patrícia para enfrentar esta situação de "não reconhecimento", após ter passado por experiências diversas, foi a de arrumar um casamento falso.

Eu casei, eu casei para pegar o documento, paguei um casamento falso para pegar o documento. Uma das soluções que você tem para poder continuar, hoje em dia é muito caro. Cada dia que passa o Consulado italiano vai cobrar mais caro, aconteceu com um amigo meu, que veio aqui no Rio frequentou a minha casa, de uma boa família ele. Ele estava precisando de dinheiro então me ajudou e eu também ajudei ele. Mas agora eu tenho que pagar o meu divórcio. Hoje em dia a lei mudou e eu já estou pegando a minha nacionalidade. Há qualquer momento... de repente até saiu quando eu chegar, se Deus quiser. Eu mereço, depois disso tudo. (Patrícia).

Porém isto resolveu o problema do reconhecimento, mas não da permanência. No relato de Patrícia vimos que o que realmente a possibilitou 
ficar mais tempo foi o fato dela ter conhecido um italiano, de quem ficou noiva e que de alguma forma custeava as suas necessidades. A possibilidade de ter 0 seu próprio negócio com a venda de biquínis foi impulsionado pelo fato do noivo, não querendo que ela se expusesse e com muitos ciúmes, ter comprado a sua primeira coleção, que depois sem ele saber ela própria comercializou, lucrando duas vezes.

Patrícia mostrou estar em conflito quanto a manter ou não este relacionamento, pois se por um lado ele the agrada e the proporciona uma "segurança", por outro, ela relata a sua insatisfação diante da possessividade dele, que às vezes a desqualifica como pessoa. Relatou que se sente humilhada quando seu noivo não gosta de alguma coisa que ela faz ou fala, pois ele reage com gritos e batendo com a própria cabeça na mesa ou na parede, já tendo também esmurrado o carro de tanta raiva.

Em 2009 fiquei de janeiro a março no Brasil e quando retornei ele foi me buscar chorando no aeroporto com um buquê de flores me levando para casa dele, pois não queria que eu fosse para a minha casa. Quando estava assistindo televisão ele entrou no quarto e comentei sobre uma discussão que ele havia tido com o pai, dizendo que ele deveria ter mais paciência com o pai dele. Ele então gritou e disse para eu calar a boca, pois "quem era eu para falar assim com ele". (Patrícia).

Tais atitudes do noivo parecem ser um dos principais motivos do desânimo atual em permanecer na Itália como havia pensado de início e não saber se permanecerá ou não com o noivo. Patrícia parece viver um conflito entre permanecer livre e sozinha, com as incertezas de viver do seu trabalho como autônoma ou, continuar noiva, de alguém que arca com suas despesas, mas também Ihe trata de maneira grosseira, desqualificando-a.

Você entende como está minha vida? Eu já tive um período que eu gostava de morar lá, mas agora enjoei e os lugares que eu gosto de ir, já me perderam o valor, eu estou lá com o objetivo de trabalho, então eu posso trabalhar aqui, porque agora eu estou perto da praia, as coisas estão mais fáceis para mim.

Ele quer casar, mas eu não quero casar com ele. Ele é italiano, não dá, eu prefiro brasileiro. Ele tem barco, ele tem uma vida melhor, minha mãe viu o barco e adorou, olhando assim, tem que casar com ele. Mas para mim não dá. Só pelo simples fato que eu não gosto daquele lugar, é lindo, os restaurantes são maravilhosos, eu como bem, bebo bem.

Minha mãe fala: "você tem que entender a oportunidade da sua vida". Tem muitas mulheres hoje que queriam estar com um noivo, que lhe dá tudo o que você quer. E eu digo: "Mãe eu quero paz".

Ele tem um problema muito grande, como todos os italianos têm, eles são muito estressados. É um estresse que é inacreditável. (Patrícia). 
Em seus relatos Patrícia afirma os estereótipos da mulher brasileira que atraem os europeus, e que em muitos momentos são apontados por ela de maneira ambígua e contraditória, como algo negativo e constrangedor e em outros, como uma oportunidade de aproximação e de relacionamento. Ela relatou a situação de algumas mulheres que conheceu que migraram na expectativa de conseguir casamento no exterior ou alguém que as sustentasse.

As brasileiras são pichadas no exterior, sem dúvida nenhuma em Milão, exatamente isto, existe um abuso muito grande com a mulher brasileira, principalmente se ela for morena, se ela for mulata e ela é sempre tachada como puta, está é a verdade. (Patrícia).

A mulher brasileira sabe dançar, sabe chegar, ela tem uma felicidade, que a cubana, p.ex., também é bonita, também tem um corpo legal, tem porte legal, também chama atenção, mas não vai comparar uma cubana com uma brasileira. Então qual é a mulher que vai se destacar no mundo? É a brasileira... eles adoram, principalmente se você for com a pele mais escura, se você for morena. (Patrícia).

A imagem da mulher brasileira como intensamente sexuada e marcada pela cor, comparece no relato de três entrevistadas, que afirmam que a imagem da brasileira no exterior está fortemente associada à prostituição.

Ele estava muito envolvido comigo. E o homem europeu quando vê uma brasileira que ele gosta, ele quer levar ela de todas as formas para ficar junto dele. Eles dizem que as brasileiras são mais amorosas, são mais amáveis, delicadas. (...) Há muito preconceito por parte das portuguesas porque elas pensam que as brasileiras vão para lá para roubar os homens delas. Isso é fato. As brasileiras lá são vistas, principalmente as negras, como prostitutas. Eu, por ser loura, ter essa aparência, eu não tenho muita característica de mulher brasileira. Lá as pessoas me viam como uma mulher de outro país, menos do Brasil, tanto é que me perguntaram várias vezes se eu era brasileira e lá eu andava muito bem vestida, de cachecol, bota e maquiada, você fica mais elegante e não sofri isso, mas existe muito preconceito com brasileira, mas em Portugal tem muita prostituição. Tem mulheres que vão para lá só para viverem disto, porque elas sabem que eles gostam de brasileira. (Michele).

Lá [Portugal] ninguém gosta de contato com brasileiro, dizem que brasileiro é morto de fome, que é isso, que é aquilo e isolam a gente. E eu só vivia dentro de casa. E olham mal a mulher brasileira. Um dia eu estava em Leri e eu fui pedir uma informação para a moça, para comprar um livro para minha filha nas Lojas Americanas que lá também tem. Eu perguntei onde era as Lojas Americanas e ela me deixou falando sozinha.(...) Porque eu sou brasileira, elas não gostam nem de conversar. Não gostam de ter contato, porque tem brasileiro que vai para lá e não vai fazer coisa certa. (Viviane).

Falou em brasileiras, carnaval, são putanas. Pelé, café e carnaval, putanas, bundas era o retrato do Brasil. (Luiza). 
Maria Luiza Heilborn (2006) em sua análise sobre os mitos e comportamentos sexuais, com objetivo de demonstrar a natureza fabricada do mito da sexualidade erotizada brasileira, ressalta que,

\begin{abstract}
Geralmente se considera que os brasileiros são mais desinibidos, "quentes", calorosos e estão sempre prontos a fazer tudo na cama. É como se o país fosse uma espécie de paraíso sexual. Essa noção foi construída historicamente: tratase de uma imagem do Brasil que remonta à ideia de que os portugueses, ao chegarem ao país, descobriram indígenas que viviam sem roupa e conheciam formas de organização social muito simples. (...) A ideia dos colonizadores era de que o Brasil era um país sem moralidade sexual, imagem que muitas vezes foi reproduzida por historiadores e viajantes europeus. Assim se apresenta uma ideologia da nacionalidade brasileira na ideia de mistura de raças. (...) Considerada responsável na cultura brasileira pelos componentes de espontaneidade, afetividade, sensualidade e da habilidade corporal para 0 samba e futebol.(...) A ideia de que a sensualidade se deve a essas raízes negras é reforçada nesse período, e é fortemente expressa no mito da sexualidade aberta e desinibida dos brasileiros. Esse mito está presente também na divulgação de um tipo de propaganda do país, na publicidade do turismo, que promove, por exemplo, a imagem da mulata: uma mulher sexualmente muito liberada "quente" e "fogosa", o resultado da miscigenação de um homem branco com uma mulher negra (p. 49-50).
\end{abstract}

Luciana Pontes (2004), em artigo que analisa a imagem das mulheres brasileiras na mídia portuguesa, afirma que existe uma grande associação entre gênero e nacionalidade e uma feminização da representação da nação brasileira.

Esse processo de feminização da representação da nação está relacionado tanto à história do imperialismo e colonialismo quanto aos processos mais contemporâneos relacionados à globalização, como o turismo internacional. Estes processos têm como pano de fundo as relações desiguais entre países, em que as relações "centro-periferia" se expressam no campo simbólico em representações de tropicalidade e exotismo, em que os diferenciais de desenvolvimento e distribuição de renda são sensualizados (p.232). Assim, vemos um processo de sexualização da mulher imigrante brasileira associado: 1) ao fato de ser imigrante, portanto, de um outro grupo étnico-nacional exótico, periférico, racializado e de uma classe econômica subalterna; e 2) ao fato de ser brasileira, portanto, oriunda da cultura do Carnaval, sexualidade, culto ao corpo e também da pobreza, violência e subdesenvolvimento. Tais estereótipos sobre o Brasil são recorrentes tanto na mídia quanto no turismo e, em grande parte, é uma ideia formada pelos estrangeiros, perspectiva da qual partem os portugueses (p.244).

Estes estereótipos de gênero e raça que informam a visão da sexualidade da mulher brasileira no exterior reforçam a ideia de desqualificação e subalternização desta, que, associada à prostituição, passa a ser vista em seu caráter delitivo e transgressivo. 
O deslocamento de mulheres pelo mundo vem sendo alvo de grande atenção haja vista a preocupação que tem ocupado a mídia e os governos através das políticas migratórias no combate ao tráfico de pessoas, em especial ao tráfico de mulheres para fins de exploração sexual.

Em muitos países o debate sobre o tráfico de mulheres, traz no bojo a problemática da imigração irregular e da prostituição.

A restrição das fronteiras na contenção da migração irregular, tem colocado o deslocamento de brasileiras sob "suspeita" ou "tutela" pela própria imagem construída no exterior, principalmente se estas são jovens, sozinhas e sem muitos recursos para migrar.

Os relatos de Geane e Luiza são emblemáticos para o estudo do tráfico de mulheres, pois são duas histórias diferentes que se caracterizam como tráfico por haver o engano ou a coação ou a sedução, por haver o deslocamento e a exploração. Trazem elementos novos para a análise, entre eles as estratégias destas mulheres para não se sujeitarem ou permanecerem em situação de exploração; trazem à tona também, a invisibilidade destas mulheres para os órgãos públicos nos países de destino, no sentido de lhes dar proteção, talvez devido ao envolvimento com a prostituição em boates e prostíbulos.

Os casos de Geane e Luiza ocorreram antes da existência do Protocolo de Palermo (2000), porém já num contexto de maior preocupação mundial com o tráfico de pessoas.

Geane saiu do Brasil como integrante de um grupo de dança, criado por sua amiga para a apresentação de shows de cultura brasileira na Espanha, mas desde a chegada ao seu destino não recebeu o prometido, devido à divida que contraiu com quem a levou, que precisava ser abatida dos ganhos obtidos com os espetáculos.

Quando a gente chegou na Espanha fomos direto para o restaurante de Alberto. Ele tinha duas casas de prostituição, um restaurante enorme, um supermercado, que ficava ao lado da casa onde estávamos. Fazíamos o show em hotéis de luxo que pagavam a ele, que era responsável de tudo. Nós não víamos o dinheiro. Depois de dois meses começamos a cobrar nosso salário. Teve então uma reunião no restaurante dele. A gente não entendia o que ele falava e Marcela traduzia. Disse que tinha um comunicado para fazer, que a partir de hoje, além de dançarmos nos hotéis teríamos que ir para a casa de puteiro, depois do show, porque vocês tem que pagar o que ele gastou com a gente no Brasil: passaporte, visto, documentação, as roupas. E que não teria essa de não querer. Eu falei para ela que eu não ia sair do hotel quando acabasse o show para trabalhar no puteiro, porque se eu quisesse trabalhar em um puteiro, ficaria no Brasil, porque em Copacabana tem muita casa de puteiro e eu não nasci para isso porque eu trabalhava em casa de família. Disse a ela que "eu não sou obrigada a fazer o 
que ele queria, então, me manda embora!" Tatiane e a irmã de Marcela levantaram e falaram a mesma coisa (Geane).

Geane relatou que pediu para a aliciadora, que anteriormente considerava ser sua amiga, que a mandasse de volta e, mediante a recusa desta, procurou a delegacia e o Consulado brasileiro, que não fizeram nada a respeito.

Em um dos seus relatos menciona que o fato de não estarem irregular, evitou que fossem presas pela polícia, mostrando que a autoridade policial espanhola estava mais preocupada com a situação de irregularidade do que propriamente com a prostituição forçada e o tráfico de mulheres.

Outro aspecto, inicialmente percebido, é que, devido a Geane conhecer bem quem a aliciou, parece que de certa forma ela ainda contava com os vínculos de amizade que um dia as uniu, não acreditando que ela poderia chegar a ações mais extremas, tanto que, na delegacia, não a denunciou, somente o dono do prostíbulo.

Chamamos as garotas, eu e Tatiane e falamos que não íamos trabalhar de prostituição ou então Marcela mandasse a gente de volta e se não mandasse de volta íamos procurar uma delegacia e dar parte. E foi o que fizemos. Reunimos as cinco e demos parte do Alberto, mas não demos parte dela, porque ele era o responsável pela gente na Espanha. A gente só tinha como documentação a tarjeta, que era uma carteirinha para andar no país, pois sem ela íamos presa pela polícia. Então falamos com o delegado que viemos para a Espanha com ele, que ele tinha uma Casa de Prostituição e que estava obrigando a gente a trabalhar na prostituição e queríamos a nossa documentação de volta, porque a amante dele havia ficado com os nossos documentos, passaportes e as passagens. O delegado foi à noite no puteiro procurar o Alberto que "amarelou", porque de noite ele ficava no puteiro e de dia ele mandava os capangas dele levar a gente de van. A polícia chegou, bateu nas duas casas de puteiro dele. Levaram umas mulheres que estavam sem documentação e o Alberto para a delegacia e ele ficou uma noite preso. No dia seguinte Alberto foi solto. Lá é tudo uma máfia, lá ele conhecia os policiais, o delegado, conhecia todo mundo, ele tinha dinheiro e podia comprar todo mundo. (Geane).

Procuramos o Consulado brasileiro, mas eles não ajudaram em nada, eles inventaram um monte de coisas que nem lembro mais. Não podia parar de fazer os shows porque era um contrato assinado durante nove meses (Geane).

No relato abaixo parece que, com exceção de Geane, Tatiane e a irmã da aliciadora que retornou ao Brasil, todos os integrantes do grupo que vieram com elas se envolveram com a prostituição, sem muita resistência. Porém não fica claro se estes já tinham envolvimento com a prostituição quando ainda estavam no Brasil e se desconheciam totalmente que iriam se prostituir na Espanha. 
As garotas foram trabalhar no puteiro, as únicas que não foram foi eu e a Tatiane, porque nós nos unimos. Os meninos também se prostituíam, faziam o jogo de Marcela, mas eles já sabiam. Quem se prostituía ganhava dinheiro. Marcela começou a colocar terror. Mas eu já a conhecia daqui, eu já sabia quem era ela, ela não ia me botar terror. Foi quando eu fechei com a Tatiane e falei para ela se unir comigo, se acontecer alguma coisa, vai morrer nós duas, mas a gente vai ter que ir até o final dessa história. Continuávamos fazendo o show e ela só pagou um mês de salário. Eu arrumei trabalho de camareira para trabalhar em hotéis, cheguei a trabalhar duas semanas, mas depois descobriam e eu só podia trabalhar para Alberto, aonde eu ia ele me "queimava".(...) Depois que a gente denunciou Alberto na delegacia e ele foi preso, Marcela virou contra a gente. Nós chegávamos dos hotéis de madrugada e ficávamos sem comer porque ela não dava comida para a gente. (Geane).

A ausência de passaporte, apreendido pela aliciadora não foi determinante para que Geane e Tatiane se sentissem obrigadas a se prostituir, contrariando a ideia vinculada em algumas campanhas de que "primeiro eles tiram o passaporte depois a sua liberdade", como se a ausência do passaporte fosse determinante para o ingresso na prostituição forçada.

Por outro lado, o relato de Geane mostra diversos momentos de resistência, o que talvez só tenha sido possível devido ao apoio fundamental de pessoas amigas na Espanha e no país de origem.

Uma grande ênfase em seus relatos diz respeito a um espanhol que conheceu e se apaixonou. De acordo com Geane ele era conhecido e amigo de Alberto, o dono das boates e dos prostíbulos. Depois se tornaram inimigos. Ele a protegeu em diversos momentos, conforme relatos abaixo.

Eu tive muita sorte de ter arrumado um espanhol que gostou de mim. Hoje em dia não sei se ele está vivo ou morto. Ele era amigo do Alberto e hoje eles são inimigos. Conheci ele no hotel e do nada, bati o olho e me apaixonei e ele se apaixonou. Ele me ajudou muito. E quando Marcela entrou no nosso quarto e jogou as passagens e disse vão embora agora! Que vocês só estão me dando prejuízo. Se não chegássemos a tempo no aeroporto iríamos perder o voo. De onde estávamos até o aeroporto era muito longe e a gente não tinha dinheiro para pagar o táxi, ligamos para o meu amigo porque a gente não tinha como ir. Ele veio, passou no banco e deu um dinheiro para a gente vir. Eu tenho que agradecer primeiro a Deus e depois a ele. Fomos para o aeroporto, conseguimos pegar o avião, que faria escala. Nós não viemos como deportadas. (Geane).

Um dia Marcela chegou do nada, começou a revirar o guarda roupa dela e depois acusou eu e Tatiane de ter roubado 1 milhão de dólares dela. Ela chamou a polícia, que eram os capangas do Alberto, que ele dava dinheiro por fora para eles ficarem calados, que levou eu e Tatiane para a delegacia. Ela foi num outro carro rindo, dando gargalhada, dizendo que nós roubamos o dinheiro dela. Chegando na delegacia, me colocaram numa sala e Tatiane em outra. E eles falavam para cada uma de nós que uma já tinha acusado a outra de pegar o dinheiro. O delegado chegou, me chamou na sala, depois chamou ela, e perguntou se a gente tinha certeza do que estava falando. Eu falei para ele como 
é que nós poderíamos pegar um milhão de dólares, pois é muito dinheiro, e aqui é euro e não dólar. Foi ai que o delegado caiu em si, mas ele também era outro que fechava com o Alberto, porque aqueles policiais tudo "comiam" Marcela no puteiro. Então ela fechava tudo com eles. Alguém ligou para o meu amigo e ele foi direto para a delegacia. Como ele tinha um irmão que era polícia, eles soltaram a gente e meu amigo levou a gente para casa. Neste dia eu chorei tanto, de humilhação, eu nunca tinha sido presa no Brasil, para ser presa lá. (Geane).

Outra pessoa que aparece no relato de Geane e que a ajudou, foi uma das clientes da boate onde aconteciam os shows.

Tinha uma espanhola que sempre ia ver nosso show, ela gostava muito do show, contamos a história para ela e ela nos levou para o Consulado com o carro dela, mas o Alberto não podia saber que ela estava por trás disto. Ela levou a gente na delegacia. Ela nos levou numa ONG que ajudou a gente a arrumar um trabalho de camareira, além de fornecer também comida. (Geane).

A família de Tatiane, amiga de Geane, também foi fundamental, tanto por pressionar a família da aliciadora, que também morava na vizinhança, para que retornassem, quanto na realização de denúncia à Polícia Federal no Brasil, levando à prisão de Marcela.

A mãe da Tatiane começou a correr, mas o Consulado não ajudou. Ela ia todo dia na casa da mãe de Marcela, para que ela pedisse à filha para mandar a Tatiane e eu de volta. E a mãe da Marcela ligava e pedia para nos mandar de volta, pois não aguentava a mãe da Tatiane todo dia na porta dela. Marcela dava gargalhadas, dizendo que ia deixar a gente sofrer mais um pouco. Marcela era tão ruim que falou que podia mandar até a Tatiane, mas eu não, que deixaria eu virar mendiga na Espanha. Porque eu morava dentro da casa dela e ela nunca esperava que eu me virasse contra a ela. Como que íamos voltar sem a passagem? A mãe da Tatiane procurou a Polícia Federal e conheceu uma advogada de direitos humanos, que pegou o nosso caso e conseguiu trazer a gente. Fizeram contato com Alberto e falaram para mandar a gente de volta. Alberto pegou chamou a Marcela e pediu para mandar a gente de volta porque ele disse que nós estávamos prejudicando muito ele (Geane).

Luiza, assim como Geane, também vivenciou situação de tráfico em sua segunda viagem para o exterior.

Na segunda viagem a coisa começou a mudar, foi quando recebemos propostas de donos boates do Rio e de São Paulo, em 1988. Foi quando eu viajei novamente com 26 anos. Eu já estava morando em Cabuçu [Nova Iguaçu], quando eu recebi uma proposta. Fizeram uma proposta enganosa ao pessoal, você vai, nós te damos passagem e estadia você vai dançar. Tinha mais uma amiga minha que foi e morreu porque estava presa às drogas e não aguentou. 
A ida foi ótima, chegamos e ficamos lá, eles conseguiram visto para 30 dias, quando deu 1 mês e eles começaram a vir com outra conversa, de que além de sambar tinha que se prostituir. Até então tinham deixado a gente em paz e foi o próprio pessoal da hotelaria que mudou a gente de quarto e conseguiam os clientes para fazer sexo. Nós aparecíamos à noite e de dia tínhamos que nos esconder, ficamos sem os documentos. Dissemos: "Nós somos sambistas, nós não somos prostitutas". Praticamente eles disseram se não se prostituir voltam a nado. Eu não aceitei. Os homens que sabiam que a gente era sambista achavam que podia fazer de tudo, abuso sexual. Eu fiquei um ano e meio em Portugal, um ano bem e meio ano horrível. Eu fiquei me escondendo em Portugal por quase um ano, dormia na rua e me prostituía na pista. (Luíza).

No relato de Luiza sobre sua segunda viagem apesar de não querer se submeter à prostituição por aqueles que inicialmente a contrataram para shows de samba, encontrou na prostituição de rua, uma estratégia de sobrevivência em Portugal.

Luiza considera ter resistido à prostituição imposta por aqueles que a contrataram. Porém remete a sua força e capacidade de resistir como um atributo masculino, reproduzindo estereótipos de gênero, que referenciam a força e a determinação como características exclusivas dos homens.

Na época eu tinha força, parecia um homem, eu simplesmente não abaixei a minha cabeça e disse eu volto a nado, quem quiser me acompanha. (Luiza).

Luiza comenta que também teve ajuda de pessoas ligadas a uma Igreja e critica a indiferença do Consulado brasileiro em Portugal.

Tinha um pessoal ligado à lgreja que acolheu a gente, dava café da manhã, a gente almoçava, a gente limpava o chão, fazia limpeza para pagar. (Luiza).

Eles não vê você como vítima, igual a mulher que apanha do marido "briga de marido e mulher, não se mete a colher" e mesmo ela não estando errada é péssimo o tratamento, eu não sei agora, mas era péssimo o tratamento. Cheguei a pedir ajuda ao Consulado brasileiro e fecharam a porta para a gente. E isso que me revoltou mais ainda. (Luiza).

Durante o relato, Luiza se mostrou muito emocionada quando falava de sua relação com as drogas. Em alguns momentos os relatos eram confusos e sem nexo, provavelmente pelo fato de que muitas das situações relatadas tenham sido vivenciadas sob o efeito das drogas, o que não tira, absolutamente, o valor do seu relato enquanto expressão de sentimentos e da percepção do significado destes acontecimentos para ela. 
Outro aspecto relevante, é que Luiza, diferente de Geane, tinha um histórico de mulata profissional ligada à apresentação de shows em boates e Casas de Espetáculos, o que poderíamos supor que isto lhe traria uma experiência maior para identificar os riscos deste negócio, pois teria contato com esta realidade há mais tempo.

Giacomini (1992) em seu estudo sobre a identidade da mulata profissional analisou a construção desta identidade, que exige para a mulata que quer se afirmar como mulata profissional, a exibição exacerbada em rituais de sedução, cujo tipo extremo é a prostituta, o que justificaria a invocação constante por parte desta mulher da demarcação entre a atividade profissional de mulata e a prostituição. Constata-se, no entanto, que, além da performance individual, os shows são concebidos numa celebração do tema da disponibilidade da mulata, principalmente através de quadros que ensejam um contato direto e malicioso com o público.

Pela história de Luiza, parece haver o mesmo que foi constatado por Giacomini (1992): uma linha tênue que separa a mulata profissional da prostituta, um estigma associado à imagem da mulata à sensualidade e à sedução. Isto fica mais evidente em sua terceira viagem, quando já aparece de forma completamente naturalizada a relação dos shows de mulatas com a atividade de prostituição.

Quando voltei pela terceira vez para exterior, eu tinha 29 para 30anos. Eu fui para a Itália pela Casa de Espetáculos que trabalhava no Rio. Eu não só sambava, mas me prostituía e a prostituição chama a droga. Fiz um aborto na Itália, eu drogada, acabei engravidando, e fiz um aborto. Ao retornar, continuei fazendo shows de samba nesta Casa de Espetáculos famosa no Rio, eu tinha um contrato com essa Casa. (Luiza).

A condição de estar presa à dívida junto à Casa de Espetáculos que a patrocinou é um dos aspectos que caracterizariam o tráfico, pois mesmo já inserida na prostituição, ela trabalhou sem ser remunerada, o que caracterizaria a exploração do trabalho através de formas análogas à escravidão.

A história de Viviane difere das outras histórias, por não ser um caso de tráfico, mas envolver uma violência extrema. Viviane foi coagida e forçada a migrar por submissão ao seu parceiro íntimo. É um caso que envolve uma situação de servidão e violência física, sexual e psicológica. 
Ele não me deixava sair de dentro de casa. A gente passava dificuldade, ele não me deixava trabalhar. Ele era o tipo de pessoa assim, íamos na Igreja e lá ele nos tratava bem. Era um amor, tratava as meninas bem. Todo muito que via achava que eu vivia bem com ele. Eu tinha muito medo dele.

Em Portugal, ele trabalhava na rua e em casa, porque ele legalizou e passou a consertar carro em casa também. Ele consertava o carro das pessoas que chegavam lá em casa, às vezes as mulheres vinham com os maridos dela para consertar carro e perguntavam por mim. Ele dizia que eu estava dormindo e que não gostava de conversar. Ele me isolava. E se subisse alguém para casa, ele mandava eu ir para a sala, conversava com a pessoa na cozinha, dava um café e mandava a pessoa embora.

Ele só me queria eu presa. Ele tinha muito ciúme de mim, ele era doente. Não deixava eu mexer na televisão, se ele via, ele brigava. O computador eu ligava, ele desligava, só podia ver quando ele estava dentro de casa, para ele poder ver o que eu estava fazendo. Não podia sair e agredia,batia muito em mim e nas meninas. Quando ele tinha que bater batia em todo mundo. E aquilo foi me sufocando, eu não aguentava mais sofrer. Me dava uma dor no estômago tão grande, que eu acordava de manhã e vomitava sem comer nada. Eu fui inchando, inchando. (Viviane).

Viviane relatou também viverem em situação de extrema pobreza. $O$ fato de serem estrangeiros e no caso dela, por estar irregular, não podia acessar os serviços de proteção social do país. Porém algumas assistentes sociais, através de suas instituições, possibilitaram algum tipo de apoio à família de Viviane.

No comecinho nós fomos morar numa aldeia, tipo uma roça. Era muito frio e no comecinho eu não tinha condições de pagar comida, então consegui através da escola que minhas duas filhas comessem lá. Eu fui lá e conversei com a assistente social. E eu fui vivendo assim.

Depois o colega do meu marido que levou ele falou assim: "Vamos para Pombal!" E ele foi para Pombal e nisso que ele chegou em Pombal os colegas foram e arrumaram um serviço para ele. Eu mudei minha filha mais velha de escola. Lá era melhor, a gente não morava na roça, a gente tinha uma casa melhorzinha. Passei muito dificuldade. Tinha uma assistente social e eu ia lá pedir roupa, comida. Sofri muito. A minha vida veio melhorar quase no finalzinho quando eu decidi vir embora. (Viviane).

Viviane, também recebeu apoio da Organização Internacional para as Migrações em Portugal, a partir da informação de uma pessoa conhecida do casal, que desconhecia esta possibilidade de conseguir a passagem de volta ao Brasil. E foi através da OIM que conheceram outra instituição que os apoiaria com a doação de alimentos. Em momento algum Viviane revelou que sofria violência doméstica. $O$ medo e o descrédito de que alguém ou alguma instituição poderia ajudá-la a sair da situação de violência, fez com que ela se mantivesse em silêncio, não revelando os reais motivos de querer retornar ao Brasil. 
Pedi muito a Deus para voltar. Ele disse que não iria pagar passagem para eu ir embora, porque eu tinha que esperar ele vender as coisas, tinha que esperar ele arrumar um serviço, tinha que esperar ele juntar dinheiro para vir embora. E ele dizia: "um dia a gente vai embora".

Nisso uma vez a colega dele foi consertar o carro e falou com ele assim, se você quiser embora e não quiser pagar passagem você tem que ir na Organização Internacional para Migrações e pedir para ser deportado. E eu escutei. Mas para ele era mais difícil, porque ele teria que entregar o documento dele. E eu já não tinha documento mesmo.

Eu fui na OIM, contei minha história para a pessoa que me atendeu, mas não disse que ele me batia senão podiam fazer alguma coisa com ele e ele não deixar eu ir. Eu pedi se tinha uma passagem para mim, porque eu estava irregular e já tinha um ano e eu não tinha como pagar a minha legalização. Eu falei que queria vir para o Brasil porque a situação estava muito difícil, passávamos fome e ele estava desempregado, sem dinheiro. Disse que eu estava doente. E estava doente dele mesmo. Eu tinha tanto medo dele, que parece que o medo passou para dentro. E hoje eu não me sinto mais mal; era tanto medo que eu sentia. (Viviane).

A OIM arrumou naquele dia açúcar, sucrilhos, arroz, feijão e mandaram eu ir numa ONG que doava alimentos. Até o dia de eu ir embora, normalizou as coisas. Eles falaram que dentro de três meses a passagem sairia. Todo o dia eu ligava. Todo dia eu orava. Saiu em um mês, de tanto eu pedir a Deus. Ele ia me matar dentro de casa. Ele era assim, ao mesmo tempo em que estava fazendo as coisas comigo, ele estava rindo na minha cara. Entendeu? Ele podia judiar de mim, maltratar, sem eu ter feito nadinha. E não se dava conta disso. (Viviane).

Outro aspecto diz respeito à própria dinâmica da violência doméstica contra a mulher que faz com que muitas delas permaneçam por anos nesta situação. Em geral isso está associado à vergonha e ao medo; à esperança que o companheiro mude de comportamento; à dependência econômica; ao isolamento; à negação social causada pela falta de apoio e de compreensão daqueles a quem a mulher recorre para sair daquela situação, entre outros fatores.

Pierre Bourdieu (2010) em sua obra "A dominação masculina", trata especificamente da dominação do masculino sobre o feminino, propondo interpretá-la como dominação simbólica. Para o autor, a dominação do homem sobre a mulher é exercida por meio de uma violência simbólica, compartilhada inconscientemente entre dominador e dominado e fundamentada através de disposições constitutivas dos esquemas práticos do "habitus":

(...) O efeito da dominação simbólica (seja ela de etnia, de gênero, de cultura, de língua etc.) se exerce não na lógica pura das consciências cognoscentes, mas através dos esquemas de percepção, de avaliação e de ação que são constitutivos dos 'habitus' e que fundamentam, aquém das decisões da consciência e dos controles da vontade, uma relação de conhecimento profundamente obscura a ela mesma. Assim a lógica paradoxal da dominação masculina e da submissão feminina, que se pode dizer ser, ao mesmo tempo e 
sem contradição, espontânea e extorquida, só pode ser compreendida se nos mantivermos atentos aos efeitos duradouros que a ordem social exerce sobre as mulheres (e os homens), ou seja, às disposições espontaneamente harmonizadas com esta ordem que as impõem (p. 49-50).

Para Bourdieu (2010) a violência simbólica como é um ato sutil, oculta relações de poder que alcançam não apenas as relações entre os gêneros, mas, toda a estrutura social e que se institui por intermédio da adesão que o dominado concede ao dominante. Para o autor, as pessoas fazem suas escolhas de vida influenciadas pelo seu "habitus", ou seja, no caminho percorrido para o alcance de seus objetivos, o indivíduo é dominado pela situação econômica, política, cultural e social onde atua.

De certa forma, tal definição, traz elementos que podem auxiliar na análise da violência doméstica, principalmente na compreensão dos motivos que fazem com que a mulher permaneça por anos submetida a este tipo de situação, como foi o caso de Viviane.

As histórias relatadas pelas mulheres entrevistadas sobre a permanência no país de destino, apesar de não poderem ser generalizadas, mostram a diversidade de situações vivenciadas e trazem uma riqueza de informações de como elas perceberam e resignificaram suas histórias de migração, bem como as estratégias utilizadas na superação das dificuldades e nas ações no cessar das violações.

\section{5 \\ O retorno ao Brasil}

O motivo que leva à decisão de retornar difere de uma mulher para outra: a saudade da família e dos amigos, a desilusão, a libertação de uma situação de opressão e exploração, o sonho realizado, a busca de novos caminhos diante da crise mundial. Porém o retorno é uma história inacabada que está se construindo para cada uma destas mulheres. O que elas apresentaram em comum foi a busca por um recomeçar em seu país de origem, recriando e reinventado as suas próprias vidas e a sua história. 
Das mulheres entrevistadas, somente Viviane retornou ao Brasil por meio da deportação, solicitada por ela à Organização Internacional para as Migrações em Portugal.

A situação de retorno mais precário foi relatada por Luiza, que após fugir de uma situação de tráfico de mulheres conseguiu a ajuda de uma ONG de Portugal para retornar até o Paraguai, clandestinamente dentro de um container.

Conseguimos sair e achar os padres, e tinha um porto e um navio que estava indo para a Argentina e nós viemos dentro de um container, o que foi conseguido pelo pessoal da lgreja de lá.

Teve umas colegas minhas que morreram ou sumiram por lá mesmo em Portugal. Na época foram doze mulheres e só quatro conseguiram voltar. Ficamos dois meses no container, água era uma vez no dia. O pessoal do navio descobriu que a gente estava no navio e que queríamos voltar para o Brasil, eles colocaram a gente para fazer show. A gente fazia show para eles e o capitão fingia que não sabia. Minha amiga não suportava a realidade, então só ficava na ilusão e caiu nas drogas. Ela morreu na Argentina, não aguentou a viagem e se jogou do navio. Saí do container, cheio de droga. Nós já estávamos viciadas na cocaína.

O navio nos deixou no Paraguai. Pegamos carona até Foz do Iguaçu. Nós conseguimos contato com meu padrinho presidente da Escola, ele ainda estava vivo, ele tinha infartado e nós ficamos sem ligação nenhuma, ficamos sem a corda daqui do Brasil, que era ele. Quando ele soube o que estava acontecendo, ele ficou preocupado também com a gente. Quando liguei a cobrar do Brasil, de Foz do Iguaçu, ele soube o que estava acontecendo ...foi que clareou. Ele foi ao Consulado... denunciou, brigou, mas não deu em nada. (Luiza).

Mesmo tendo sido vítima de tráfico de mulheres, Luiza retornou mais uma vez ao exterior, desta vez financiada pela Casa de Espetáculos na qual trabalhava no Rio de Janeiro. Com esta viagem contraiu uma dívida, que continuou a ser paga após o seu retorno ao Brasil:

Todo o mês a gente pagava com o trabalho dentro desta Casa e em outra boate que fica em Copacabana. Então a gente ficava ali só para pagar as contas. E a dívida não diminuía só aumentava. Quando eu voltei, mesmo estando no Brasil, eu continuei pagando a dívida, e a divida disparou. Foi uma complicação tão doida o que fizeram, que eu não fiquei com nada. O dono da Casa de Espetáculos do Rio também era famoso pelo show de mulatas, eu consegui alugar um apartamento. Para ele tudo era dinheiro, muito dinheiro. Eu vim parar de pagar a divida no final da década de 1990, quando eu tirei a algema. E se não pagasse sumia, desaparecia. (Luiza).

Luiza avalia que não teve sorte e nem tinha na época a visão mais ampla, que segundo ela, as profissionais do sexo têm agora em relação ao trabalho sexual. 
Hoje em dia está tudo mais fácil, eu não tive sorte e nem uma visão mais ampla que minhas amigas hoje têm (...) A prostituição mal feita, está acabando. Hoje a profissional do sexo, paga o governo como profissionais e devem ser respeitadas (Luiza).

Afastada da família, ela mora sozinha e longe de seu filho que não quer contato com ela devido a sua história de vida e seu envolvimento com as drogas. Hoje ela se dedica ao trabalho voluntário através de uma ONG que atua com mulheres e que também Ihe presta atendimento e apoio para os diversos tratamentos de saúde a que tem que submeter por estar com AIDS, câncer e sequelas de leptospirose.

Em relação ao que vivi não recebi nenhuma ajuda. Quem até acabou de pagar mesmo foi meu companheiro que era caminhoneiro, e com o qual tive um filho que faleceu em 2000. Eu tirei minha carteira de habilitação e fiquei copiloto de caminhão, me tornei caminhoneira e botei um ponto final em tudo. Agora chega, basta! Meu companheiro morreu de AIDS e meu filho também, e eu não sabia. Eu nunca desconfiei. (Luiza).

Geane conseguiu retornar com Tatiane, fugindo da exploração de Marcela e do espanhol Alberto. A pressão de parentes de Tatiane aqui no Brasil sob a família de Marcela e a informação da denúncia à Polícia Federal, fez com que a aliciadora as deixasse voltar, sendo posteriormente presa quando veio ao Brasil.

Quando voltamos ao Brasil nós fomos ao escritório da advogada de direitos humanos, que a mãe de Tatiane teve contato, ela entrou em contato com um delegado da Polícia Federal e ele queria saber de tudo que se passou em detalhes, perguntando se tinha mais meninas lá. E perguntou quando Marcela voltava ao Brasil, a gente não sabia quando ela voltaria.

Como tínhamos muito contato aqui com nossas amigas, vizinhas que moram tudo perto dela. E muita gente ficou revoltada com que ela fez e eu sou uma pessoa muito querida aqui, onde eu chego todo mundo gosta de mim.

A filha dela iria fazer quinze anos e a gente sabia que ela viria ao Brasil fazer a festa. Foi quando eu descobri que ela tinha chegado através de uma amiga que morava perto da casa dela e me avisou.

Avisamos à advogada e à Polícia Federal e demos o endereço dela. A delegada na época disse-nos que já sabia a hora que iria ser a festa de quinze anos da filha dela. Esperaram a festa acabar, ela foi para casa descansar e a Polícia Federal chegou às seis da manhã, muito carro na rua. A polícia bateu e a primeira a sair foi ela de baby-doll, no dia seguinte da festa de quinze anos da filha.

Com o Alberto não aconteceu nada nem aqui nem na Espanha, ele pagou uns advogados e com ele não aconteceu nada. Ela foi presa por tráfico de mulheres e por ter levado a filha menor. Saiu em tudo quanto é capa de jornal. Ela pegou seis anos, mas como tinha bom comportamento, saiu na condicional e já pagou o que ela estava devendo. (Geane). 
Segundo Geane, apesar de Marcela ter cumprido sua pena, hoje, continua levando mulheres para a Espanha.

Ela já voltou para Espanha, casou com um espanhol, se tornou evangélica, fez um casarão para ela aqui e deu para a irmã morar e a mãe dela faleceu de câncer. Ela levou a filha para morar com ela na Espanha, mas a filha não gostou e voltou.

Depois disso tudo ela ainda continua a levar mulheres lá para fora, porque foi uma amiga com ela, mas essa minha amiga já sabia que era para trabalhar de puteiro. Minha amiga foi e voltou, foi quando o juiz chamou esta minha amiga para depor e perguntou se ela sabia que era para trabalhar na prostituição e ela disse que sabia. (Geane).

Geane não recebeu nenhum tipo de apoio e proteção social do governo brasileiro, mesmo seu caso vindo a público. A única ação foi da Polícia Federal e da justiça, na prisão e responsabilização da aliciadora. Sabemos que nesta ocasião (1999) não existia a Política Nacional de Enfrentamento ao Tráfico de Pessoas no Brasil e que a ação preponderante nestes casos era a repressão ao crime organizado transnacional, sem que houvesse ações de proteção às vítimas.

\begin{abstract}
O governo nunca deu nenhuma assistência para a gente, só foi essa questão do processo. Só recebemos ajuda de duas instituições não governamentais, uma delas queria arrumar psicólogo para mim e Tatiane, pois eu estava muito revoltada e só queria matar essa infeliz, mas não podia porque ela ainda estava na Espanha.

Hoje em dia eu estou aqui, moro neste quarto com banheiro e trabalho como diarista e vou vivendo a minha vida e ela no bem-bom. E ela se esconde atrás da Bíblia, porque para mim ela está se escondendo, porque para mim ela continua, mas com alguém que ajuda ela por trás. Com certeza ainda há o tráfico, pela questão do trabalho. Eles chegam aqui e falam que você vai ganhar dólar, euro, eles fazem a sua cabeça de um jeito, que você pensa em juntar dinheiro lá fora para depois vir comprar uma casa, um carro. Mas quando chega lá, não é nada disso.

Passamos nove meses sem ganhar salário. Não recebemos nenhuma indenização nos processos que abrimos na Espanha contra ele. Outro advogado pediu para uma advogada que ele conhecia da Espanha para ver o processo, mas ela disse que estava arquivado. (Geane).
\end{abstract}

Apesar da situação de tráfico vivida por Geane, a mesma pensa em voltar, mas agora de uma forma mais segura, através de um trabalho com pessoas de confiança. Geane ainda permanece vivendo em condições precárias de vida e trabalho e talvez por isso, vislumbra a possibilidade de outras oportunidades fora do Brasil. Parece que a experiência vivida, mesmo sendo 
negativa, despertou-a para o fato de que a emigração pode ser uma oportunidade.

Se eu tivesse que voltar lá para fora, que seja com um trabalho fixo e não enganada igual eu fui. Às vezes eu penso em ir, mas até tenho medo, porque eu penso que vai ser tudo a mesma coisa. Tem uma amiga que foi agora para a Itália como baby sister, mas é coisa direita, família direita. Se minha atual patroa me chamasse para ir, porque são pessoas de confiança e minha tia trabalha para esta família há vinte anos, falta um ano para minha tia se aposentar. Se for por uma pessoa que eu não conheça, eu não vou. Naquela época eu fui porque eu morava na casa dela e também não desconfiei. (...) eu aprendi muita coisa na Espanha; consegui uma ONG que arrumou um emprego para mim de camareira e aprendi como forrar uma cama, lavar louça. (Geane).

Para Viviane o retorno ao Brasil representou romper com a violência doméstica e um resgate dela mesma, apesar das poucas certezas quanto ao seu futuro e das crianças.

\begin{abstract}
No dia em que eu estava arrumando a minha mala e minha passagem saiu, foi a maior felicidade da minha vida. Eu já estava ficando coma cabeça desparafusada. Eu cheguei aqui gorda, hoje eu estou magra, fiquei gordona de tanto ficar presa e de sofrimento.

Eu separei dele quando cheguei aqui no Brasil e falei com ele que tinha separado dele. Eu botei na cabeça dele que eu ia vir na frente, por causa das dificuldades que a gente estava passando. Depois ele vinha embora para a gente ficar junto aqui. Um mês que eu estava aqui eu falei para ele que não queria mais nada com ele. Ele ficou revoltado e deixou de falar comigo. Eu troquei o chip do meu telefone para ele não falar mais. E ele ligava para minha mãe, ligava todo dia e minha mãe dizia que não aguentava mais falar com ele, que ficava perturbando. Então cheguei e falei para ele o porquê eu não queria mais viver com ele. Ele sabia o que ele fazia comigo. (Viviane).
\end{abstract}

Viviane ao retornar, ainda dependia do auxílio financeiro do ex-marido. Porém, ela deixa de cobrar do ex-marido, o que poderia se considerar uma pensão alimentícia para as filhas, quando encontra um novo companheiro, passando a depender financeiramente desse.

A ruptura de Viviane com a violência não significou uma alteração nas relações de gênero, pois mesmo em um novo relacionamento ela ainda permanece numa relação de dependência e subordinação. O agravamento das condições de vida pela pobreza parece que também contribuiu para essa continuidade. 
Cheguei aqui dia em 31 de março de 2010, eu fiquei na minha mãe uns dez dias e depois eu fui arrumar um lugar lá onde eu moro hoje. Minha mãe foi lá dentro na favela e conseguiu um barraquinho para eu morar. Eu não estava acostumada, mas minha mãe disse que eu tinha que começar de novo, que começar do nada. Custei a acostumar. Eu já tinha morado na favela, mas era muito nova, tinha morado quando tinha uns três anos junto com a minha mãe. Depois nós mudamos para uma casa boa e mais tarde voltamos a morar aqui em Jardim América.

No começo foi difícil, mas ele ainda mandava dinheiro e com este dinheiro eu fazia compras, comprava umas coisas para as meninas. Ele mandava, mas eu tinha que brigar para ele mandar. Minha mãe até falou para eu parar de me humilhar. Tinha mês que ele mandava dinheiro e outro não; depois ele parou de vez e foi quando eu comecei a passar dificuldades mesmo.

Eu conheci meu namorado e no comecinho ele não me dava nada. Eu chegava para minha mãe e perguntava o que eu deveria fazer, eu estava namorando esse rapaz e precisando das coisas e perguntava se ela achava que eu deveria pedir a ele. E ela falava: "Ué?! Ele está contigo, ele tem que te dar as coisas". Depois de algum tempo ele passou a me ajudar, e eu passei a não pedir mais nada ao pai das meninas. (Viviane).

Viviane foi deportada, retornando com o auxílio da OIM - Organização Internacional para as Migrações, que também enviou por uma organização não governamental no Brasil uma quantia em dinheiro para ela realizar um curso, que pudesse ajudá-la a se inserir no trabalho.

Viviane, porém, gastou o dinheiro com uma televisão e um DVD para as filhas. Pareceu-nos que foi uma forma de compensar e mostrar para as crianças que ela poderia dar o conforto que tinham em Portugal.

A OIM me deportou, porque eu quis e negociei isto. Eu assinei um termo que durante dois anos eu não posso entrar em Portugal, só depois de dois anos que eu posso voltar. Se eu quiser voltar antes deste tempo, eu posso, mas eu terei que pagar ao governo o que ele gastou comigo e minha passagem. Mas eu não pretendo voltar. E eles mandaram um dinheiro para eu fazer um curso de computação e acabou que eu não fiz e comprei a televisão e um DVD pequeno para as meninas. Eu pensei, eu já não tenho nada. Para mim e as meninas era muito difícil a vida lá, porque ele maltratava muito, mas tinha televisão, tinha coisa boa e as meninas viviam num conforto.

Quando cheguei aqui, a única coisa que eu entreguei aqui as autoridades foi o passaporte da minha filha caçula que estava vencido. Não recebi nenhuma ajuda do Consulado brasileiro, porque não cheguei a procurar e quem me ajudou foi a OIM. (Viviane).

O Retorno Voluntário Assistido consiste,

(...) no apoio conferido aos nacionais de países terceiros que decidem sair, de forma voluntária, de um Estado membro da União Europeia. Nesta medida, o retorno assistido tem como pressuposto a vontade dos beneficiários em regressarem aos seus países de origem (Serviço de Estrangeiros e Fronteiras, 2009, p.5). 
Esse apoio refere-se à concessão de uma passagem aérea, dinheiro para a viagem e um subsídio de reintegração.

O retorno assistido em Portugal vem sendo desenvolvido pelo Estado português em parceria com a OIM. Os princípios gerais sobre esta matéria

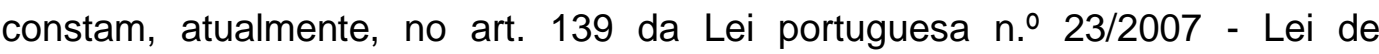
Estrangeiros. Esta lei dispõe que o cidadão estrangeiro beneficiário do Programa após a sua saída, e durante os três anos seguintes, não poderá retornar a Portugal, salvo se os apoios financeiros auferidos forem restituídos somando, aos mesmos, os juros referentes à taxa legal.

Portugal é o único país que adota este tipo de proibição referente ao retorno assistido, entre os vinte e sete estados europeus que mantêm protocolos com a Organização Internacional para as Migrações, relativos à gestão de programas de Retorno Voluntário em todo o mundo (Felner, 2005).

O retorno é tanto um processo de adaptação para quem emigrou quanto para aqueles que permaneceram, o novo estilo de vida, os novos hábitos no âmbito do consumo e até mesmo as habilidades adquiridas no mercado de trabalho, a partir da migração, podem representar entraves à reinserção e readaptação na sociedade de origem (CSEM, 2011).

O retorno não diz respeito só ao espaço físico do deslocamento, mas principalmente ao espaço social. Neste sentido o retorno nunca será à volta ao que havia antes de migrar, é um recomeço de uma pessoa que já não é a mesma de antes.

O contato com a trajetória de migração destas mulheres residentes na região metropolitana do Estado do Rio de Janeiro mostrou a diversidade e a singularidade de suas histórias, que apesar de não possibilitar a generalização, permitiu conhecer a percepção destas mulheres sobre a sua própria história ressignificada.

A pesquisa de campo trouxe uma riqueza de vivências, que mesmo particulares, informam relações e contextos sociais mais amplos destas mulheres, permitindo através da análise das diferentes experiências narradas, verificar a existência de nexos entre a condição de gênero, a migração e o tráfico, que aparecem na motivação para migrar, na permanência e na decisão de retornar.

A motivação para migrar decorreu, para a maioria das entrevistadas, a partir de um convite de pessoas conhecidas, amigas ou com quem mantinham um relacionamento afetivo, trazendo uma perspectiva de mudança das condições de vida e trabalho, além de status. Tal fato mostra a importância das 
redes sociais no processo de migração, conforme já constatado nos estudos migratórios.

O financiamento da viagem por terceiros foi fator fundamental na tomada de decisão de migrar, sem o qual, estas mulheres não teriam recursos financeiros para deixar o país ou demorariam mais tempo para fazê-lo.

Verificou-se também que a existência de redes de amizade ou a atuação de instituições, principalmente não governamentais, que fornecem algum tipo de apoio a migrantes nos países de destino, foi importante para a permanência e proteção no exterior ou mesmo no retorno de algumas destas mulheres para o Brasil.

No caso de Geane e de Luiza, que foram vítimas de tráfico, foi possível verificar o envolvimento de donos de casas de shows, hotéis, boates e prostíbulos, no Brasil e no exterior, na exploração da prostituição e no financiamento do aliciamento de mulheres, com promessas enganosas de trabalho.

Pôde-se fazer uma distinção clara entre a prostituição voluntária e aquela forçada, que caracteriza o tráfico. O que não significa, como ocorreu no caso de Luiza, que mesmo na prostituição voluntária não possa haver a exploração por meio da ausência de remuneração sob o argumento de pagamento da dívida.

Neste caso, o consentimento de Luiza em trabalhar na prostituição, não dava o direito ao seu contratante de não remunerá-la, como em qualquer outro trabalho. O consentimento na caracterização do tráfico é tido como irrelevante. Mas, verifica-se que, a ausência de uma maior proteção das trabalhadoras sexuais em relação aos seus direitos trabalhistas, faz com que se submetam, sem concordar, às situações de abuso de poder por parte daqueles que as contratam.

O tráfico, porém não é a única forma de violência vivida por mulheres que migram. A violência doméstica também aparece como determinante na decisão de migrar, que no caso de Viviane, se deu sob forma de coação. As situações relatadas por Patrícia com seu noivo, nas quais se sente humilhada e desrespeitada, também pode se caracterizar, como uma forma de violência doméstica psicológica.

Os relatos das entrevistadas, principalmente aquelas que vivenciaram situações de tráfico de pessoas, revelam a inexistência ou a referência negativa aos Consulados do Brasil no exterior, sempre como inoperantes ou ineficazes. Outra referência negativa é a polícia, que apareceu nos relatos, mais 
preocupada com a migração irregular e em conivência com a exploração da prostituição, do que com a proteção de mulheres que solicitavam ajuda.

Ao retornarem do exterior, algumas entrevistadas tiveram o apoio de instituições não governamentais, que tomaram conhecimento de sua história. Porém o poder público só é mencionado na fala de Geane, quando se refere à ação da Polícia Federal.

Em muitos momentos, os relatos levaram ao questionamento das visões já consolidadas sobre o tráfico de mulheres. A articulação das situações particulares apresentadas pelas mulheres, com o conhecimento produzido pelos estudos migratórios e pelos estudos de gênero, possibilitou uma visão mais ampla dos aspectos econômicos, políticos, culturais e sociais que incidem sobre a migração feminina, principalmente de mulheres sozinhas, oriundas de países do Terceiro Mundo, com poucos recursos financeiros e aparentemente sem proteção.

Assim, informações produzidas sobre mulheres migrantes e principalmente, traficadas, devem levar em consideração esta diversidade e estes diferentes aspectos, para não se ocorrer o risco da criação e execução de políticas migratórias e de enfrentamento ao tráfico, ineficientes e ineficazes, que ao invés de garantir os direitos dessas mulheres, possam expô-las ainda mais a outras formas de violação. 


\section{6 \\ Conclusão}

Este estudo buscou construir uma argumentação, diante de um tema tão complexo como o tráfico de pessoas, que identificasse os nexos existentes entre condição de gênero, migração feminina e tráfico.

A escolha de não enfocar apenas o tráfico, mas sim pensá-lo dentro de um contexto maior da migração internacional, possibilitou encontrar outros nexos, como os interesses econômicos e políticos presentes na nova ordem mundial de capitalismo globalizado, que vão influir na decisão de Estados, que passarão a utilizar o discurso de combate ao tráfico de pessoas para maior controle das fronteiras.

Apesar das muitas mudanças ocorridas no mundo contemporâneo, estas não significaram uma mudança expressiva nas relações de gênero. As mulheres ainda sentem de forma mais contundente a sua desvalorização e desqualificação em relação aos homens.

As desigualdades sociais no país de origem, a violência e a busca por melhores condições de vida e trabalho, aparecem como fatores que impulsionam a migração feminina, porém não significam uma alteração em relação aos papéis sexuais, baseados na construção de gênero.

A percepção da mulher como um "grupo vulnerável", permeará também as ações do próprio Estado que com a visibilidade da migração feminina e o crescimento de sua importância passará a exercer um maior controle e tutela sobre o deslocamento da mulher.

As disparidades econômicas e sociais entre os países também vão acirrar estas diferenças, fazendo com que mulheres, principalmente oriundas de países subdesenvolvidos ou em desenvolvimento, sejam vistas como suspeitas de migração irregular ou como prostitutas.

A ação de restrição à imigração por diversos países no combate ao tráfico de pessoas acaba motivando a busca dos que querem emigrar, por intermediários mediante o contrabando de pessoas, expondo-as ainda mais ao risco de serem traficadas. Mas isso parece não ser uma preocupação dos Estados. 
Um do aspectos enfocados neste estudo foi mostrar o percurso na construção da concepção contemporânea de tráfico, que só passa a ser considerado um crime, uma prática ilegal que viola os direitos humanos, a partir do século $X X$ com a criação de documentos internacionais com a participação de diversos países. O próprio sujeito do tráfico também passa por um processo de transformação: da mulher branca a mulher tanto adulta como criança sem a conotação de raça e em seguida incorpora a "pessoa", isto é, não mais diferenciando os gêneros.

Verificou-se que nem sempre a atividade do tráfico foi considerada ilegal, mostrando que aspectos econômicos, políticos e culturais foram determinantes para que o tráfico de pessoas para escravidão no mundo antigo (greco-romana) e no mundo moderno (africanos para as Américas) fosse considerada uma prática legal. De acordo com Martins (1994) a escravidão estava definida pelo costume e pela lei e ganhava sentido no fato de que legalmente o cativo era mercadoria.

Os escravos, homens e mulheres negros africanos, sustentavam a classe dominante colonial e, em parte, as classes dominantes metropolitanas interessadas no pacto colonial, além de permitir 0 assalariamento de trabalhadores especializados, forneciam recursos para a renovação dos meios de trabalho e para a continuidade do tráfico.

Os interesses econômicos explicam por que em muitos países a abolição do tráfico para trabalho escravo foi postergada.

Considerados uma raça inferior pelo determinismo biológico, os negros eram desconsiderados em sua humanidade e direitos. O que explica o porquê do tráfico de negros africanos para as Américas ser considerado uma prática legal por tanto tempo. Neste sentido o pânico moral e o repúdio ao tráfico surge com as histórias do tráfico de mulheres brancas europeias e não com a escravidão negra.

Isso se deve ao fato de que na época, a mulher branca apesar de ser considerada inferior ao homem branco, por sua condição de gênero, era, contudo, considerada superior ao homem e a mulher negros, devido a sua condição de raça.

Outro aspecto é que o tráfico de escravas brancas aparece associado à vinda de grandes levas de migrantes em busca de melhores oportunidades no Novo Mundo. Para os países receptores a migração europeia nos fins do século XIX e início do século XX era estimulada para que houvesse "branqueamento", para a ampliação demográfica ou mesmo para a substituição da mão de obra 
escrava por outra, de trabalhadores livres qualificados para o trabalho na indústria ou no campo.

A condição de migrante, mesmo que motivada pelos países de destino, não protegia de um trabalho altamente explorado, visto que não existiam nas sociedades capitalistas, experiências de proteção social promovidas pelos Estados.

Nem por isso, estas condições de exploração, a que se submetiam estas pessoas que se deslocam com o sonho de construir a vida em outro país, com promessas falsas e enganosas, não foram consideradas como situações de tráfico na época. Isso porque esta exploração era condição intrínseca do próprio capitalismo e por isso não haveria de se falar do tráfico para trabalho forçado.

Acredita-se que diante das condições de vida que encontravam no país de destino, estes imigrantes não eram só vistos como mão de obra barata e mais qualificada que auxiliaria no desenvolvimento, mas também como ameaça, devido ao movimento operário a partir de meados do século XIX em diversos países da Europa, em que os trabalhadores, tomados pela consciência de classe para si, entram no cenário político reivindicando seus direitos, principalmente ao trabalho.

Em relação à migração feminina nestes fluxos migratórios do sec. XIX, não se tem dados, pois essa ainda não tinha visibilidade em projetos de migração tidos como masculinos.

Porém, parece que o tráfico de escravas brancas chamou atenção para o deslocamento de mulheres sozinhas, para trabalhar, inclusive, na prostituição. Algo atípico para a época, considerando que a moralidade e a visão de inferioridade que se tinha da mulher, não a concebiam como alguém que pudesse ser autônoma, correr riscos e se aventurar ao transitar sem proteção, algo colocado como típico dos homens.

Acredita-se que a suposta "autonomia" e " liberdade" dessas mulheres, tenha provocado uma maior vigilância dos governos de diversos países, tanto de origem como de destino, para estes deslocamentos e para a inserção destas mulheres migrantes na prostituição. Para os países de origem a preocupação poderia ser pela saída de mulheres oriundas de um mundo desenvolvido, que ajudariam no crescimento e na construção da riqueza de países subdesenvolvidos ou em desenvolvimento. Para os países receptores, as histórias de tráfico eram alardeadas por países, como os EUA e aqueles da Europa, com quem estes países receptores, saídos da situação de colônia 
mantinham relações e por isso também deveriam se mostrar preocupados com o tráfico de mulheres.

O pânico moral provocado pelas histórias de mulheres brancas escravizadas sexualmente justificou, na época, ações contra imigrantes indesejáveis e o controle da prostituição, apesar da existência de poucos dados empíricos que confirmassem a amplitude do tráfico.

Viu-se, na época, que o surgimento do movimento feminista procurou a princípio os ideais de igualdade, com poucos questionamentos sobre as teses deterministas. E que frente ao tráfico de mulheres brancas desencadeou um movimento de abolição da prostituição, considerada uma violência sexual contra a mulher.

Um destaque foi conferido ao pensamento de Emma Goldman, uma feminista anarquista, que no ápice do pânico moral, tece duras críticas ao Estado e aos capitalistas, denunciando a tentativa destes em ocultar, através das histórias das escravas brancas, as péssimas condições de trabalho a que eram submetidas as operárias, pois a condição feminina era razão da desqualificação.

Para Goldman a dimensão dada ao tráfico de mulheres brancas para a prostituição, servia para desviar a atenção para a situação das trabalhadoras dentro das fábricas, como mão de obra mais barata que a do homem. Estas mulheres, na divisão sexual do trabalho, também tinham o papel importante não só na produção, como mão de obra mais barata, mas na reprodução social, pela educação dos filhos e pela realização de tarefas ligadas ao cuidado através de serviços domésticos que ajudavam na manutenção de sua família.

Acrescentando a isso, vê-se que a prostituição deveria ser desestimulada como opção de trabalho para estas mulheres, que poderia lhes render até mais do que ganhavam na fábrica, ainda mais numa sociedade que a oferta de mão de obra era maior que a demanda de trabalho, constituindo-se num exército industrial de reserva.

Como diversas vezes mencionado por Margareth Rago e Cristina S. Pereira, na reflexão sobre o tráfico de escravas brancas e a prostituição no Brasil, muitas mulheres emigravam sabendo que iriam se prostituir por que já exerciam esta atividade no país de origem ou mesmo nunca tendo se prostituído, estavam dispostas a tentar a vida nesta atividade, principalmente aquelas sem nenhuma qualificação ou experiência de trabalho.

Verificam-se alguns aspectos da crítica de Goldman presentes na atualidade nos discursos das feministas pós- modernas, quando estas alertam para o uso ideológico das ações de combate ao tráfico para ocultar a ação dos 
governos no combate à prostituição e à migração irregular ( Kempadoo, 2005; Doezema; 2000/2004).

Tais aspectos se confirmam em diversos trechos neste estudo, quando se analisa os documentos produzidos, tanto pelos organismos supranacionais (ONU, OIT entre outros) como no âmbito interno dos diversos países, que a prioridade não tem sido a proteção às vítimas e aos direitos humanos de migrantes, sejam esses mulheres ou homens, mas a proteção dos interesses econômicos e políticos dos Estados.

Estas reflexões iniciais sobre o tráfico de escravas brancas no séc. XIX parecem ter marcado profundamente o discurso sobre o tráfico de mulheres, e são de certa forma retomadas e reatualizadas no debate contemporâneo deste tema.

O debate sobre o tráfico de pessoas no século $X X$ ganha novo fôlego a partir dos anos 90, coincidindo com a intensificação dos fluxos migratórios dos países subdesenvolvidos ou em desenvolvimento para países desenvolvidos, assim como, com as mudanças na economia mundial advindas da reestruturação produtiva.

As histórias de mulheres traficadas e os números alarmantes divulgados por organismos internacionais vêm auxiliando na construção de um perfil de vítima, que aponta para mulheres pobres dos países em desenvolvimento ou subdesenvolvidos, que tentam sair de seu país. Isso vem trazendo implicações para este deslocamento, pois muitas são deportadas ou não admitidas em outros países devido a estes estereótipos.

Na prevenção ao contrabando e ao tráfico de pessoas, são estabelecidas políticas migratórias mais repressivas. Os países de destino que consideram o tráfico como uma ameaça para a segurança nacional, encontram na deportação das pessoas traficadas, as quais são principalmente mulheres, uma solução que acaba convertendo as vítimas em criminosos.

Verificou-se que a definição contemporânea contida no Protocolo de Palermo, ainda traz muitas indefinições e lacunas, não se tendo chegado a um consenso sobre os pontos-chaves como "exploração", "outras formas de exploração", "situação de vulnerabilidade", ficando a cargo dos Estados-nação a interpretação que melhor Ihes convier, conforme as leis internas do país.

Também se deixou a cargo dos Estados os dispositivos que objetivam promover a defesa e a proteção daqueles que foram traficados.

Porém, os grandes debates na definição do tráfico são entre coalizões informadas por grupos feministas que divergirão sobre a forma como concebem 
a prostituição. Este debate implica diretamente no entendimento do conceito de exploração.

Viu-se que aspectos morais serão decisivos neste debate, prevalecendo a tendência a uma visão abolicionista , ao excluir da classificação de tráfico para trabalho forçado, a exploração sexual, colocando-a desassociada do conceito de prostituição voluntária como uma modalidade de trabalho.

Esta concepção também aparecerá nas campanhas anti-tráfico, através da divulgação de imagens exclusivamente de mulheres, encarceradas, acorrentadas e submetidas à prostituição. Ignorando assim, o tráfico para outras finalidades que não só a exploração sexual, e que a existência de outras vítimas, que não só mulheres.

A exploração do trabalho sexual é vista exclusivamente como uma violência sexual contra a mulher, ou seja, independente da prostituição ser voluntária ou forçada, por si só já seria considerada exploração sexual.

Há, contudo, um consenso entre os participantes na elaboração do Protocolo de Palermo, que a prostituição forçada e a prostituição de crianças e adolescentes, são crimes de tráfico, se existir o deslocamento entre fronteiras para este fim.

O documento dedica grande parte do seu texto à especificação do fortalecimento de regimes de fronteira e à proteção das pessoas traficadas, sobretudo em termos de repatriação. O que de certa forma confirma a prevalência da preocupação com a migração pelas fronteiras sobre a proteção aos direitos humanos das vítimas de tráfico.

A legislação brasileira é trazida neste estudo mostrando que apesar do Brasil ter ratificado o Protocolo de Palermo, alterou bem pouco o conceito na legislação brasileira, que considera apenas o tráfico internacional e interno, somente para fins de exploração sexual.

O contato com instituições, uma governamental e outra, um consórcio de instituições não governamentais, possibilitou abordar as ambiguidades e contradições em se adotar conceituações tão distintas, como a do Protocolo de Palermo (contido na Política Nacional de Enfrentamento ao Tráfico de Pessoas) e do Código Penal brasileiro, e, as dificuldades de implementação de ações e articulação de uma rede para o enfrentamento do tráfico.

Ademais, verificou-se que as instituições apontam para uma maior incidência de casos para trabalho escravo do que para a exploração sexual.

O caso brasileiro mostra que dependendo da concepção que tenha, cada país pode adotar uma direção diferenciada e desta forma, não podermos afirmar 
que há realmente uma concepção universalmente aceita sobre o que seja o tráfico.

Ao serem as mulheres as apontadas por documentos oficiais como as principais vítimas do tráfico de pessoas, verifica-se a necessidade de se repensar a questão migratória também a partir da dimensão de gênero.

A pesquisa de campo foi pensada com a finalidade de confrontar a realidade de mulheres que haviam migrado ao debate teórico sobre o tráfico.

A localização destas mulheres não foi um processo fácil, visto que muitas delas passam invisíveis, e assim se mantêm, caso não revelem suas histórias para alguém que as registre.

O contato com a trajetória de migração de mulheres residentes na região metropolitana do Estado do Rio de Janeiro mostrou a diversidade e a singularidade de suas histórias, que apesar de não possibilitar a generalização, permitiu verificar que algumas questões trazidas a partir da pesquisa bibliográfica, também foram sinalizadas por estas mulheres.

A pesquisa teve como ponto de partida a motivação dessas mulheres para migrar e buscou identificar a partir dos relatos as condições de permanência no país de destino - redes de apoio, formas de sobrevivência, relação com órgão públicos, estratégias diante de situações de violação de direitos, como o tráfico - a situação de tráfico e a decisão de retornar.

A importância das redes sociais no processo de migração, tanto no país de origem como no destino, aparecem como fundamentais na motivação para migrar, inclusive no financiamento da viagem, assim como para a permanência no destino, conforme já salientaram muitos estudos sobre migrações.

Verificaram-se situações de tráfico em dois casos, porém as histórias de vidas levantadas fazem crer que a complexidade das situações não permite se falar em um padrão de vítima e nem de aliciamento. Porém percebeu-se que a fragilidade ou inexistência de redes de apoio no país de origem e de destino e a saída com poucos recursos, são aspectos que podem colocar a mulher em situações de risco pela precarização das condições de permanência.

Além disto, viu-se nestes casos, a ausência de proteção dada pelo Estado às pessoas em situação de tráfico, evidenciando uma preocupação maior com a migração irregular do que com o apoio à vítima.

Em muitos momentos, os relatos levaram ao questionamento das visões já consolidadas sobre o tráfico de mulheres.

Foi possível verificar o envolvimento de donos de casas de shows, hotéis, boates e prostíbulos, no Brasil e no exterior, na exploração da prostituição e no 
financiamento do aliciamento de mulheres, com promessas enganosas de trabalho.

Pôde-se fazer uma distinção clara entre, por um lado, da prostituição voluntária e, por outro aquela forçada e que caracteriza o tráfico. Porém verificou-se que mesmo na prostituição voluntária pode existir a exploração por meio da ausência de remuneração sob o argumento de pagamento dívida; neste caso, trata-se de tráfico para trabalho forçado.

A precariedade em que se dá o trabalho sexual na prostituição voluntária, sem qualquer proteção trabalhista, possibilita a existência de situações de abuso de poder por parte daqueles que contratam essas mulheres. E, muitas vezes, essas mulheres se mantêm em silêncio visto que suas falas são desvalorizadas e desqualificadas por serem prostitutas.

O tráfico, porém não é a única forma de violência vivida por mulheres que migram. A violência doméstica também aparece como determinante na decisão de migrar e de retornar.

A existência da exploração para fins de obtenção de lucro é condição de caracterização do tráfico, por isso nos casos vistos que envolviam violência doméstica, mesmo existindo a coação, o deslocamento e a servidão, estes não são tidos como tráfico.

As histórias destas mulheres confirmaram a existência de estereótipos em relação à mulher brasileira, que envolvem aspectos de gênero e raça, que a associam à prostituição. $O$ que nos relatos foi apontado ora como algo negativo e ora como positivo, sendo um atrativo para quem procura um parceiro.

Outro aspecto, é que apesar de terem sido vítimas de tráfico, as mulheres narram o desejo de emigrar novamente, indo de encontro à postura assumida por muitos países que veem na deportação, com o compromisso de não retornarem por alguns anos, a melhor solução para este problema.

Em relação ao retorno, verificou-se nas entrevistas que essas não tiveram apoio em seu retorno ao Brasil, permanecendo ainda em situação igual ou pior do que aquela em que se encontravam antes de emigrar. A ação do Estado, quando existiu foi na repressão e punição dos aliciadores e ajuda que foi obtida de instituições não governamentais no Brasil e no exterior.

Viu-se que existe uma moralização do deslocamento feminino, que coloca esta mulher em evidência nos estudos de tráfico, como alguém que precisa de maior proteção do que outras pessoas, devido a sua condição de gênero. E por outro lado esta proteção não é efetivada quando esta mulher busca este apoio. Ao invés de garantir os direitos dessa mulher, passam a expô- 
las ainda mais a outras formas de violação. Isso de deve ao fato de que os interesses do Estado estão acima dos direitos humanos dessa mulher migrante e vítima do tráfico.

Por fim, pretendeu-se com este estudo repensar certos conceitos e ações no enfrentamento ao tráfico de mulheres, evitando a construção de "verdades" e procurando problematizar algumas ambiguidades e contradições presentes na abordagem deste tema, com o objetivo de subsidiar novos debates. 


\section{Referências Bibliográficas}

ADRIJASEVIC, R. Trafficking in Women and the Politics of Mobility in Europe. Teses de Doutorado na Universidade de Utrecht/ Países Baixos, orientadora RosiBraidotti. 2004. Disponível em: http:// igiturarchive.library.uu.nl/dissertations/2005-0314-013009/index.htm>

AGUSTIN, L. Migrants in the Mistress's House: other voices in the "trafficking" debate. In: Social Politics: International Studies in Gender, State and Society, 12(1), Oxford University Press, 2005, p. 96-117

ALENCAR, E. C. O. de. Tráfico de seres humanos no Brasil: aspectos sócio jurídicos - o caso do Ceará. Dissertação de Mestrado. Universidade de Fortaleza/ Centro de Ciências Jurídicas, 2007.

ANDERSON, B.; DAVIDSON, J. O. Trafficking - a demand led problem? A multy-country pilot study. Part I: Review of evidence and debates. Save the children, 2004. Disponível em: http://www.jagori.org/research_dst.htm. Acesso em: 12 nov. 2005.

ARIZA, M. Ya no soy la que dejé atrás - mujeres migrantes em República Dominicana. México: Plaza/Valdez, IIS, 2000.

ARONOWITZ, A. A. Smuggling and trafficking in human beings: the phenomenon, the markets that drive it and the organizations that promote it. In: European Journalon Criminal Policy and Research, 9 (2), 2001, p. $163-195$

ARRUDA, S. M. Notas acerca do crime de tráfico de órgãos. In: Revista Eletrônica PRPE, maio de 2004. 
ASSIS, G. de O.; SIQUEIRA, S. Mulheres emigrantes e a configuração de redes sociais: construindo conexões entre o Brasil e os Estados Unidos. In: Revista Interdisciplinar da Mobilidade Urbana - Redes Migratórias, Brasília, Centro Scalabriniano de Estudos Migratórios, ano XVII, n. 32, v.17, 2009.

AUSSERER, C. Controle em nome da proteção: análise crítica dos discursos sobre tráfico internacional de pessoa. Dissertação de Mestrado. RJ: Instituto de Relações Internacionais, PUC-Rio, 2007.

BASSIOUNI, C. M. Tráfico de Mulheres e Crianças para fins de Exploração Sexual. Anais do Colóquio Internacional do Rio de Janeiro. Rio de Janeiro, 2002.

BECKER, H. S. Métodos de Pesquisa em Ciências Sociais. São Paulo: Ed. Pioneira, 1999.

BERTAUX, D. L'approche biographie: sa validité méthodologique, les potentialités. Cahiers Internationaux de Sociologie, LXIX, p. 197-225, 1980. Apud SPINDOLA, T.; SANTOS, R. da S. Trabalhando com a história de vida: percalços de uma pesquisa(dora?) In: Revista Escola de Enfermagem,USP,2003; 37(2),p.119-26.

BHABHA, J.; ZARD, M. Smuggleg or trafficked? In: Forced Migration Review, n.25, 2006, p.6-8.

BLANCHETTE, T. Emma Vermelha e o espectro do "Tráfico de Mulheres". In: Cadernos Pagu n.37, julho-dezembro de 2011, p.287-297. Dossiê: Violência: Outros Olhares.

BLANCHETTE, T.; SILVA, A. P. da. "Nossa Senhora da Help": sexo, turismo e deslocamento transnacional em Copacabana. In: Cadernos Pagu, n. 25, Campinas jul/dez, 2005.

BORDIEU, P. A dominação masculina. Tradução Maria Helena Kühner. 8 ed. Rio de Janeiro: Bertrand Brasil, 2010. 
BORDIEU, P. Apud Preuss, M. R. G. A Abordagem Biográfica - História de Vida - na Pesquisa Psicossociológica In: Revista Série Documenta, ano VI, 1997, n. 8, UFRJ.

BRASIL. Código Penal Brasileiro. São Paulo: Saraiva, 2010.

- Congresso Nacional. Relatório Final da Comissão

Parlamentar Mista de Inquérito-CPMI. Criada por meio do Requerimento n. 02 , de 2003-CN, com a finalidade investigar as situações de violência e redes de exploração sexual de crianças e adolescentes no Brasil. Brasília, julho de 2004.

. Lei 11.340 de 07 de agosto de 2006 - Lei Maria da Penha.

Disponível em: http://www.planalto.gov.br/ccivil_03/_ato20042006/2006/lei/l11340.htm Acesso em: julho de 2012.

- Ministério das Relações Exteriores. Atos multilaterais assinados pelo Brasil no âmbito do Direito Penal. Disponível em: <http://www2.mre.gov.br/daí/dpenal.htm>. Acesso em: 18 jan. 2006. . Ministério do Trabalho e Emprego. Classificação Brasileira de Ocupações - $C B O$. Brasília, 2008. Disponível em: http://www.mtecbo.gov.br/informacao.asp Acesso em: 17/11/2008.

BRIOSCHI, L. R.; TRIGO, M.H.B. Relatos de vida em ciências sociais: considerações metodológicas. Ciência e Cultura, 1987; 39 (7): 631-7.

BRUCKERT, C. Trafficking in Human Beings and Organized Crime: a literature review. Universityof Ottawa. 2002. Disponível em: http:// www.rcmp-grc.gc.ca/pdfs/traffick_e.pdf

BUTLER, J.; RUBIN, G. Tráfico sexual - entrevista In: Cadernos Pagu n.21, 2003, p.157-209.

CASTELLANOS, P. C. Mujeres migrantes de América Latina y el Caribe: derechos humanos, mitos y duras realidades. Serie Población y desarrollo. Santiago del Chile: CEPAL, 2005, n. 61. 
CIPRIANI, R. Biografia e Cultura - da religião à política. In: VON SIMSON, O. (Org.). Experimentos com Histórias de Vida: Itália-Brasil. São Paulo: Vértice, 1988.

CENTRO SCALABRINIANO DE ESTUDOS MIGRATÓRIOS. Resenha Migrações na Atualidade - Migração de Retorno e crise: sonho frustrado? Ano 21, n.84, Setembro 2011. Disponível: http://www.csem.org.br

COMISSÃO ECONÔMICA PARA A AMÉRICA LATINA E O CARIBE CEPAL. Globalização e desenvolvimento. Relatório da 29a Sessão. Brasília, 2002.

DAL LAGO, A. Non-persone. L'esclusionedei migrante in uma societáglobale, 2005 Apud AUSSERER, Caroline. Controle em nome da proteção: análise crítica dos discursos sobre o tráfico internacional de pessoas. Dissertação de mestrado. Pontifícia Universidade Católica do Rio de Janeiro, 2007.

DE VRIES, P. "White Slaves" in a Colonial Nation: the Dutch Campaign against the Traffic in Women in the Early Twentieth Century. In: Social \&legal Studies, n.14(1), p.39-60, 2005.

DERKS, A. From write slaves to trafficking survivors - Notes on the trafficking debate. Princeton University, Center for Migration and Development, Working Paper, 2000. Disponível em: http:// www.nswp.org/pdf/CMD-0002M.PDF.

DITMORE, M.; WIJERS, M. The negotiations on the UN Protocolo in Trafficking in Persons. In: Nemesis, n.4, 2003,p.79-88.

DOEZEMA, J. A crescer! La infantilización de la mujeres em los debates sobre "trafico de mujeres". In: OSBORNE, Raquel(ed). Trabajador@s del sexo. Derechos, migraciones y trafico en el siglo XXI. Barcelona, Edicions Bellaterra, 2004. 
DOEZEMA, J. Loose women or lost women? The re-emergence of the myth of "white slavery" In: Contemporary Discourses of "Trafficking" Gender Issue, 18 (1), 2000, p.23-50. Disponível em: http://www.walnet.org/csis/papers/doezema-loose.html.

. Now you see her, now you don't: sex workers at the UN Trafficking Protocol Negotiations. In: Social \& Legal Studies, 14(1), 2005, p.61-89.

Who gets to choose? Coercion, Consent and the UN Trafficking Protocol. In: Gender and development, v.10, n. 1, mar 2002, p.20-27.

DONNAN, H.; WILSON, T. M. Borders: frontiers of identity, Nation and State. Oxford : Berg 1999 Apud AUSSERER, Caroline. Controle em nome da proteção: análise crítica dos discursos sobre tráfico internacional de pessoa. Dissertação de Mestrado. RJ: Instituto de Relações Internacionais, 2007.

DURHAM, E. R. A caminho da cidade. São Paulo: Perspectiva, 1984.

ENGELS, F. A origem da família, da propriedade privada e do Estado. Tradução Leandro Konder. 9 ed. Rio de Janeiro: Civilização Brasileira,1984.

FELNER, R. D. Imigrantes apoiados no retorno, proibidos de regressar a Portugal. In: Observatório da Imigração, 31 de Outubro de 2005. Disponível em: http://www.oi.acidi.gov.pt/modules.php?name=News\&file=article\&sid $=768$

FERREIRA, I. T. C. M. A Construção Social do Tráfico de Pessoas. Dissertação apresentada ao Programa de Pós-Graduação em Antropologia Social do Museu Nacional. UFRJ, 2009.

FOUCAULT, M. Vigiar e punir: nascimento da prisão. Tradução de Lígia M. Ponde Vassallo. Petrópolis: Vozes, 1978. 
FRASER, N. O feminismo, o capitalismo e a astúcia da história .In: Revista Mediações, Londrina,v.14, n.2, p.11-33, jul/dez. 2009.

GAATW- Aliança Global contra Tráfico de Mulheres. Direitos humanos e tráfico de pessoas: um manual. Tradução Patrick Carvalho e Luciana Campello Ribeiro de Almeida, 2006.

GALLAGHER, A. Trafficking, smuggling and human rights: tricks and treaties. In: Forced Migration Review, n. 12, 2002.

GIACOMINI, S. M. Aprendendo a ser mulata: um estudo sobre a identidade da mulata profissional. In: COSTA, A. de O.; BRUSCHINI, C.. Entre a virtude e o pecado. Rio de Janeiro: Editora Rosa dos Tempos; São Paulo: Fundação Carlos Chagas, 1992.

GLAT, R. Ser Mãe e a Vida Continua. Rio de Janeiro: Editora Agir, 1993.

GOLDMAN, E. Tráfico de mulheres, 1909 [Tradução: Mariza Corrêa]. In: Cadernos Pagu, n.37, julho-dezembro de 2011, p. 247-262.

GRUPO DA VIDA. Prostitutas, "traficadas" e pânicos morais: uma análise da produção de fatos em pesquisas sobre o "tráfico de seres humanos". In: Cadernos Pagu, n. 25, 2005, p.153-184.

GUIMARÃES, M. de F. Trajetória dos Feminismos: introdução a abordagem de gênero. In: CASTILLO-MARTíN, M.; OLIVEIRA, S. de. (Orgs.). Marcadas a ferro: violência contra a mulher, uma visão multidisciplinar. Brasília: Secretaria Especial de Políticas para as Mulheres, 2005.

HAGUETTE. M. T. Metodologias Qualitativas na Sociologia. Petrópolis: Vozes, 1987.

HARDING, S. Ciência y feminismo. Madrid: Morata, 1993.

HEILBORN, M. L. Entre as tramas da sexualidade brasileira In: Revista Estudos Feministas, Florianópolis,14(1), janeiro-abril, 2006. 
HIRATA, H. Globalização e divisão sexual do trabalho. In: Cadernos Pagu n.17/18, 2001/2002: p.139-156.

HOFMAN, C. Coalition contre le trafic des femmes In: Prostituerest-il un droithumain? NQF, v. 21, n. 2, 2002, p. 137-146.

IAMAMOTO, M. O serviço social na contemporaneidade: trabalho e formação profissional. SP: Cortez, 2001.

IAMAMOTO, M.; CARVALHO, R. Relações sociais e serviço social no Brasil. São Paulo: Cortez, 1983.

JESUS, D. E. de. Tráfico internacional de mulheres e crianças - Brasil: aspectos regionais e nacionais. São Paulo: Saraiva, 2003, p. 30-31.

KAPUR, R. Travel plans: border crossings e the rights of transnational migrants. In: Harvard Human Rights Journal, v. 8, 2005.

KEMPADOO, K. Mudando o debate sobre tráfico de mulheres In: Cadernos Pagu, n. 25, Campinas, jul./dez, 2005.

. The Migrant Tightrope: Experiences in the Caribean. In: KEMPADOO, K; DOEZEMA, J. (Orgs.). Global Sex Workers - Rights, Resistance, and Redefinition. Nova lorque e Londres: Routledge, 1998.

KYLE, D.; KOSLOWSKI, R. (Orgs.).Global Human Smuggling: Comparative Perspectives. Baltimore, The John Hopkins University Press, 2001.

LACZKO, F. Data and research on human trafficking international migration, 43, 2002, p.5-16.

LAQUEUR, T. Inventando o sexo. Corpo e gênero dos gregos a Freud. Tradução Vera Whately. Rio de Janeiro: Relume Dumará, 2001. 
LAQUEUR, T. Making Sex, Body and Gender from the Greks to Freud .Harvard: University Press, 1994. Apud ARÁN, M. Os destinos da diferença sexual na cultura contemporânea In: Revista de Estudos Feministas, v.11, n.2, Florianópolis, jul./dez. 2003.

LEAL, M. L. P. Relatório nacional da pesquisa de tráfico de mulheres, crianças e adolescentes para fins de exploração sexual comercialPESTRAF. Brasília: CECRIA, 2002.

LISBOA, T. K. Fluxos migratórios de mulheres para o trabalho reprodutivo: a globalização da assistência. In: Revista Estudos Feministas, Florianópolis, 15(3), setembro-dezembro, 2007.

LONG, L. D. Anthropological Perspectives on the Trafficking of Women for Sexual Exploitation. In: International Migration, 42(1), 2004, p.5-31.

LUTZ, H. Geschecht, ethnizitat, profession - Die neue Dienstmädchenfrage. Apud LISBOA, T. K. Fluxos migratórios de mulheres para o trabalho reprodutivo: a globalização da assistência. In: Revista Estudos Feministas, Florianópolis, 15(3), setembro-dezembro, 2007.

MAGLIANO, M. J.; DOMENECH, E. E. Género, política y migración en la agenda global. Transformaciones recientes en la región sudamericana. In: HERRERA, G.; RAMÍREZ, J. (editores). América Latina migrante: Estado, famílias e identidades. Ecuador: FLACSO/ Ministerio de Cultura del Ecuador, 2008.

MARINUCCI, R.; MILESI, R. Migrações internacionais contemporâneas. Disponível: http://www.migrante.org.br/as_migracoes_internacionais_contemporaneas _160505b.htm Acesso em:11 de mai. 2009.

MARTINE, G.. A globalização inacabada. Migrações internacionais e pobreza no século 21 In: São Paulo em Perspectiva, v.19, n.3, São Paulo, jullho/setembro de 2005. 
MARTINS, J. de S. A reprodução do capital na frente pioneira e o renascimento da escravidão no Brasil In: Tempo Social - Revista de Sociologia. USP, v.6, n. 1-2, 1994.

MASSEY, D. et al. The social organization of migration In: Return to Aztlan: the social process of international migration from Western Mexico. Berkeley: University of California Press, 1987, p. 139-171.

MENEZES, Lená Medeiros de. Os estrangeiros e o comércio do prazer nas ruas do Rio (1889-1930). Rio de Janeiro: Arquivo Nacional,1992.

MORALES, O. W. La migración de lasmujeres? Um proyecto individual o familiar? In: Revista Interdisciplinar da Mobilidade Humana, ano XV, $\mathrm{n}$. 29, 2007.

MOURA GOMES, J. de; PEREIRA, L. Traffiking in Women and Girls. In: MUNIZ, A. J.; HORTA, C. (Orgs.). Uniting People, Uniting Peoples: Americas Model United Nations (AMUN). Brasília: Fundação Alexandre de Gusmão, 2005, p.229-252

NICHOLSON, L. Interpretando o gênero. In: Revista Estudos Feministas, v.8, n. 2, 2000.

NYE, A. Teoria feminista e as filosofias do homem. Rio de Janeiro: Record/Rosa dos Tempos,1995.

ORGANIZAÇÃO DAS NAÇÕES UNIDAS - ONU. Convenção para a Repressão do Tráfico de Mulheres Maiores, concluída em Genebra, a 11 de outubro de 1933.

. Convenção para a Repressão do Tráfico de Pessoas e Lenocínio, Nova York, 1949. Disponível em: http://www2.mre.gov.br/dai/lenocinio.htm. 
ORGANIZAÇÃO DAS NAÇÕES UNIDAS - ONU. Protocolo Adicional à Convenção das Nações Unidas contra o Crime Organizado Transnacional Relativo à Prevenção, Repressão e Punição do Tráfico de Pessoas ,em especial de Mulheres e Crianças, 2000.

- Protocolo Adicional relativo ao Combate ao Tráfico de Migrantes por Via Terrestre, Marítima e Aérea. 2000.

. Protocolo de Emenda da Convenção para a Repressão do Tráfico de Mulheres e Crianças ,concluída em Genebra, a 30 de setembro de 1921.

Trends in International Migrant Stock: The 2008 Revision.

Disponível

em:

http://www.un.org/esa/population/migration/UN_MigStock_2008.pdf

ORGANIZAÇÃO DOS ESTADOS AMERICANOS - OEA. Convenção Interamericana para Prevenir, Punir e Erradicar a Violência Contra a Mulher - Convenção de Belém do Pará (1994).

ORGANIZAÇÃO INTERNACIONAL DO TRABALHO - OIT. Estimativa Global da OIT sobre Trabalho Forçado 2012. Disponível em: http://www.oit.org.br/sites/default/files/topic/gender/doc/relatoriote2012fact _846.pdf .

ORGANIZAÇÃO INTERNACIONAL DO TRABALHO - OIT. Relatório Global do seguimento da Declaração da OIT sobre Princípios e Direitos Fundamentais no Trabalho - 2001. Conferência Internacional do Trabalho, 89a Reunião 2001. Relatório I (B). Genebra, Secretaria Internacional do Trabalho, 2001.

. Uma aliança global contra o trabalho forçado. Relatório Global do seguimento da Declaração da OIT sobre Princípios e Direitos Fundamentais no Trabalho - 2005. Conferência Internacional do Trabalho, 93를 Reunião 2005. Relatório I (B).Genebra, Secretaria Internacional do Trabalho, 2005. 
PARRENÃS, R. S. Entre as mulheres - Desigualdades de trabalho doméstico e de gênero entre as migrantes na nova economia global. In: Concilium 298, 2002/5, p.28-41.

PATARRA, N. L. Governabilidade das migrações internacionais e direitos humanos: o Brasil como país de emigração. Seminário "Brasileiros no Mundo", organizado pelo MRE, Divisão de Comunidades Brasileiras no Exterior. 17 e 18 de julho de 2008. Palácio Itamaraty. Rio de Janeiro.

PATEMAN, C. O contrato sexual. Trad. Marta Avancini. São Paulo: Paz e Terra,1993.

PEARSON, R. Gender perspectives on health and safety in information processing: learning from international experience. Women Encounter Technology. Changing Patterns of Employment in the Third World.London/NY/Routledge? UNU Press, 1995, p. 278-302

PEIXOTO, J. Tráfico. Contrabando e Imigração Irregular. Os novos contornos da imigração brasileira em Portugal In: Revista Sociologia, Problemas e Práticas, n. 53, 2007, p. 71-90.

PEREIRA, C. S. A vida na janela: uma história social da prostituição no Rio de Janeiro contemporâneo .Tese de Doutorado, Unicamp, 2002.

Que tenhas teu corpo: uma história da prostituição no Rio de Janeiro das primeiras décadas republicanas. Rio de Janeiro: Arquivo Nacional, 2006.

Lavar, passar e receber visitas: debates sobre a regulamentação da prostituição e experiências de trabalho sexual em Buenos Aires e Rio de Janeiro, fim do século XIX In: Cadernos Pagu, n. 25, Campinas, jul/dez de 2005. 
PISCITELLI, A. Antropologia, direitos humanos e o debate sobre a indústria transnacional do sexo. Paper para o Simpósio sobre direitos humanos, direitos sexuais e direitos reprodutivos na 25a Reunião Brasileira de Antropologia, Goiânia, junho de 2006.

. Brasileiras na indústria transnacional do sexo. In: Nuevo Mundo-Mundos Nuevos, v. 7, p. 20, 2007.

. Entre a praia de Iracema e a União Europeia: turismo sexual internacional e migração feminina. In: PISCITELLI, A.; GREGORI, M. F.; CARRARA, S. (Orgs.). Sexualidades e saberes: convenções e fronteiras. Rio de Janeiro: Garamond, 2004.

. Entre as "máfias" e a "ajuda": a construção de conhecimento sobre o tráfico de pessoas In: Cadernos Pagu, n. 31, Campinas: Unicamp, julho -dezembro de 2008.

. Re-criando a (categoria) mulher? Campinas, novembro de 2001. Texto digitalizado.

. Traficadas ou autônomas? A noção de consentimento entre brasileiras que oferecem serviços sexuais na Espanha (no prelo), p. 0405. Apud ALENCAR, E. C. O. de. Tráfico de seres humanos no Brasil: aspectos sócio jurídicos - o caso do Ceará. Dissertação de Mestrado. Universidade de Fortaleza/ Centro de Ciências Jurídicas, 2007.

PONTES, L. Mulheres brasileiras na mídia portuguesa. In: Cadernos Pagu, 23, julho-dezembro/2004.

PORTUGAL. Lei dos Estrangeiros - Lei n. 23 de 4 de Julho de 2007. Aprova o regime jurídico de entrada, permanência, saída e afastamento de estrangeiros do território nacional.

. Serviço de Estrangeiros e Fronteiras. Retorno Assistido e Reintegração em Países Terceiros: Programas, Estratégias e Incentivos. Portugal: 2009. 
RAGO, M. Os prazeres da noite: prostituição e códigos da sexualidade feminina em São Paulo 1890 - 1930. Rio de Janeiro: Paz e Terra, 1991.

Prefácio à Emma Goldman. Tráfico de Mulheres. In: Cadernos Pagu, n.37 Campinas jul./dez. 2011. Dossiê: Violência: Outros Olhares

RAPPORT, N.; OVERING, J. Social and cultural anthropology. The Key concepts. Londres: Routledge, 2000.

RATHA. D., et al. Remittance Trends 2007.In: Migration and Development Brief 3. Nov. 2007. Disponível em: <http://siteresources.worldbank.org/EXTDECPROSPECTS/Resources/47 6882-1157133580628/BriefingNote3.pdf> Acesso em 30 jan. 2008.

RUBIN, G. El tráfico de mujeres: notas sobre la "economía política" del sexo. In: Revista Nueva Antropologia, noviembre, año/vol. VIII, número 30, Universidad Nacional Autónoma de México, 1975[Traduzido para o português e publicado por SOS Corpo e Cidadania].

SAARI, S. Balancing between inclusion and exclusion: The EU's fight against irregular migration and human trafficking from Ukraine, Moldova and Russia, 2006. Disponível em: http://www.lse.ac.uk/Depts/intrel/pdfs/EFPU\%20Challenge\%20Working\%2 0Paper\%203.pdf\#search=\%22Balancing\%20between\%20inclusion\%20an d\%20exclusion\%22

SALES, L. M. M.; ALENCAR, E. C. O. Tráfico de seres humanos, migração, contrabando de migrantes, turismo sexual e prostituição algumas diferenciações. In: Novos Estudos Jurídicos, 13(1), jan- jun 2008, p.29-42.

SALT, J. Trafficking and human smuggling: a European perspective In: International Migration, 38 (3), 2000, p. 31-56.

SANTOS , B. de S.; Gomes, C.; Duarte, M. Tráfico sexual de mulheres: Representações sobre ilegalidade e vitimação. In: Revista Crítica de Ciências Sociais, Portugal, n.87, Dezembro 2009, p.69-94. 
SASSEN, S. The mobility of labor and capital. Nova York: Cambridge University Press, 1988.

SCOTT, J. W. Preface a gender and politics of history. In: Cadernos Pagu, n. 3, Campinas/SP 1994.

. Entrevista com Joan Wallach Scott. In: Estudos Feministas, Rio de Janeiro, v.6 n.1, 1998.

SCOTT, J. W. Gênero: uma categoria útil para a análise histórica. Recife: SOS Corpo, 1996.

SCOULAR, J. The "subject" of prostitution - Interpreting the discursive, symbolic and material position of sex/work in feminist theory.2004. Apud AUSSERER, C. Controle em nome da proteção: análise crítica dos discursos sobre tráfico internacional de pessoa. Dissertação de Mestrado. RJ: Instituto de Relações Internacionais, 2007.

SILVA, A. et al. Conte-me sua história: reflexões sobre o método história de vida. In: Mosaico: estudos em psicologia, 2007, v. 1, n. 1, p.25-35

STOLCKE, V. Es el sexo para el género como lar aza para la etnicidad? Cuadernos para el Debate, n. 6, 1999, p. 5-32.

TAVARES, M. Prostituição. Diferentes posicionamentos no movimento feminista, s.d. Disponível em: http://www.umarfeminismos.org/grupostrabalho/pdf/prostituicaomantavare s.pdf. Acesso em: 28/10/2009

UÇARER, E. M., Trafficking in Women: Alternate Migration of Modern Slave Trade? In: MEYER, Mary K. e PRÜGL, Elisabeth. Gender politics in global governance. Maryland/USA: Rowman \& Litttlefield Publishing Group, 1999, p.230-244.

UNFPA. United Nations Population Fund. Situação da População Mundial 2006 - Passagem para Esperança: Mulheres e Migrações Internacionais. 2006. 
UNIÃO EUROPEIA. Convenção do Conselho da Europa relativa à Luta contra o Tráfico de Seres Humanos, de 16 de Maio de 2005.

VAINER, C. B. Deslocamentos compulsórios, restrições à livre circulação: elementos para um reconhecimento teórico da violência como fator migratório. XI Encontro Nacional de Estudos Populacionais da ABEP.

VASCONCELOS, M.; BOLZON, A. Trabalho forçado, tráfico de pessoas e gênero: algumas reflexões. In: Cadernos Pagu , n.31, julho-dezembro de 2008, p.65-87. 


\section{8 \\ Apêndices}

\section{1 Apêndice 1 - Termo de Consentimento Livre e Esclarecido (mulheres)}

Declaro, por meio deste termo, que concordei participar da pesquisa de campo, mediante concessão de entrevista, referente ao projeto de tese desenvolvido pela doutoranda Ebe Campinha dos Santos, aluna do Programa de Pós-Graduação em Serviço Social da Pontifícia Universidade Católica do Rio de Janeiro, que tem por objetivo conhecer e analisar a relação existente entre a construção de gênero, deslocamento de brasileiras através da migração internacional e o tráfico de mulheres.

Estou ciente que por intermédio deste Termo, são garantidos a mim os seguintes direitos: 1) solicitar, a qualquer tempo, maiores esclarecimentos sobre a utilização dos dados; 2) sigilo absoluto sobre seu nome, apelido, data de nascimento, número de documentos pessoais, local de trabalho, endereço residencial, estabelecimento educacional que estuda, bem como quaisquer outras informações que possam levar a uma identificação pessoal; 3) a ampla possibilidade de negar-se a dar quaisquer informações para além do perguntado e que julgue ser prejudicial a sua integridade física, moral e social; 4) recusar a dar informações que julgue prejudiciais a minha pessoa; 5) a opção de solicitar que determinadas falas e/ou declarações fornecidas aos profissionais não sejam utilizadas ou incluídas em qualquer documento, seja ele oficial ou não, que será prontamente atendida; 6) desistir, a qualquer tempo, solicitando a não utilização dos dados para fim deste ou de qualquer outro estudo.

Declaro que autorizei a gravação da entrevista, com a finalidade exclusiva de garantir a fidelidade dos dados coletados e que após a 
entrevista será transcrita e o acesso e a análise dos dados coletados se farão apenas pela pesquisadora e/ou sua orientadora. E que, uma cópia assinada deste Termo de Consentimento Livre e Esclarecido foi deixada comigo conforme recomendações da Comissão Nacional de Ética em Pesquisa (CONEP).

Fui também informada sobre os contatos da pesquisadora responsável, a quem poderei contatar/consultar a qualquer momento que julgar necessário pelo telefone (21) 9815-7192 ou pelo e-mail ebecamp@ig.com.br.

Rio de Janeiro, / / 2011.

Assinatura da participante:

Assinatura da pesquisadora: 


\section{2 \\ Apêndice 2 - Termo de Consentimento Livre e Esclarecido (Instituições)}

Declaro, por meio deste termo, que concordei em ser entrevistada na pesquisa de campo referente ao projeto intitulado, Tráfico e Gênero: a moralização do deslocamento feminino, que tem como objetivo conhecer e analisar os nexos existentes entre a construção de gênero, mobilidade feminina de brasileiras através da migração internacional e 0 tráfico de mulheres, desenvolvida pela doutoranda Ebe Campinha dos Santos, aluna do Programa de Pós-Graduação em Serviço Social da Pontifícia Universidade Católica do Rio de Janeiro (PUC-Rio).

Fui informado(a), ainda, de que a pesquisa é orientada pela professora Sonia Giacomini, a quem poderei contatar/consultar a qualquer momento que julgar necessário através do telefone(21) 3527-1555/ 1556 ou pelo e-mail sgiacom@pu-rio.br. Também fui informada sobre os contatos da pesquisadora responsável, Ebe Campinha dos Santos, a quem poderei contatar/consultar a qualquer momento que julgar necessário pelo telefone (21) 9815-7192 ou pelo e-mail ebecamp@ig.com.br.

Afirmo que aceitei participar por minha própria vontade, sem receber qualquer incentivo financeiro e com a finalidade exclusiva de colaborar para o sucesso da pesquisa. Fui informado (a) dos objetivos estritamente acadêmicos do estudo, que, em linhas gerais visam conhecer a atuação da instituição junto às mulheres migrantes e/ ou traficadas. Ao término da pesquisa os resultados serão socializados através da apresentação e entrega de uma cópia da tese de doutorado para as instituições participantes.

Fui também esclarecido (a) de que os usos das informações por mim oferecidas estão submetidos às normas éticas destinadas à pesquisa envolvendo seres humanos, da Comissão Nacional de Ética em Pesquisa (CONEP) do Conselho Nacional de Saúde, do Ministério da Saúde. 
Minha colaboração se fará de forma anônima, se assim desejar , por meio de entrevista a ser gravada, a partir da assinatura desta autorização. No caso de não querer me identificar fica assegurado o sigilo, mediante a não divulgação de dados que possibilitem minha identificação, apenas da instituição que represento. As informações obtidas através dessa pesquisa serão confidenciais, podendo ser utilizadas apenas para a finalidade deste estudo.

Fui informada que a gravação visa melhorar a qualidade e fidelidade dos dados coletados e que após a gravação a entrevista será transcrita e o acesso e a análise dos dados coletados se farão apenas pela pesquisadora e/ou sua orientadora.

Esta pesquisa não oferece qualquer risco para sua relação social, familiar, profissional, nem para a sua segurança e nem para a sua saúde. Mas como benefício, poderá contribuir para a ampliação do conhecimento sobre mulheres brasileiras que emigram e o tráfico de mulheres.

Estou ciente de que, caso eu tenha dúvida ou me sinta prejudicada, poderei contatar a pesquisadora responsável ou sua orientadora, ou ainda o Programa de Pós-Graduação em Serviço Social da PUC-Rio, situado na Rua Marquês de São Vicente, 227, Vila dos Diretórios, Gávea, Rio de Janeiro (RJ), telefone (21) 3527-1290, fax (21) 3527-1291.

A pesquisadora responsável pela pesquisa deixou comigo uma cópia assinada deste Termo de Consentimento Livre e Esclarecido conforme recomendações da Comissão Nacional de Ética em Pesquisa (CONEP).

Fui ainda informada de que posso me retirar desse estudo a qualquer momento, sem prejuízo para minha relação profissional ou sofrer quaisquer sanções ou constrangimentos.

Rio de Janeiro, de de 2011.

Assinatura da participante:

Assinatura da pesquisadora: 


\section{3}

\section{Apêndice 3 - Carta de Apresentação às Instituições}

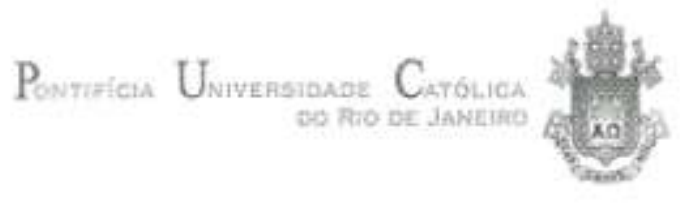

Rio de Janeiro, de de 2011.

De: Programa de Pós-Graduação em Serviço Social da PUC-Rio

Para:

Prezado(a) Senhor(a),

Venho pela presente apresentar a doutoranda Ebe Campinha dos Santos, regularmente matriculada no Programa de Pós-Graduação em serviço Social da PUC-Rio, que encontra-se na fase de realizaçăo da pesquisa de campo para elaboração de tese.

0 tema da pesquisa Tráfico e gênero: a moralização do deslocamento feminino tem por objetivo conhecer e analisar os nexos existentes entre a construçáo de gênero, mobilidade feminina de brasileiras através da migraçâo internacional e o tráfico de mulheres.

Para que seu trabalho de campo se realize, venho solicitar a colaboraçăo na concessão de entrevista por um representante institucional e a viabilização do contato com mulheres atendidas pela instituiçáo e que tenham emigrado e retornado ao Brasil, e que tenham vivenciado, ou não, situaçảo de tráfico de mulheres.

A pesquisadora entrará em contato com essa instituição a fim de agendar dia e horário da entrevista com representante institucional e com as mulheres que desejarem livremente participarem da pesquisa, sendo as entrevistas realizadas após a explicaçáo da finalidade e propósito da pesquisa, garantindo que serăo observados todos os critérios éticos condizentes com pesquisas que lidam com seres humanos.

O objetivo da entrevista com as instituiç̧ôes é conhecer a sua atuaçâo com migração feminina e/ ou tráfico de mulheres. Com as mulheres atendidas por esta instituiçaao, a entrevista visa conhecer a história de emigraçâo, os motivos da saída do país e a trajetória até o retorno ao Brasil.

$\mathrm{Na}$ expectativa de poder contar com a colaboração desta instituiçâo, agradeço a atençâo dispensada ao assunto, colocando-me à disposiçăo para outras informaçóes julgadas necessárias.

Atenciosamente,

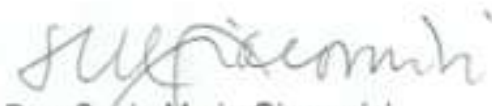

Dra. Sonia Maria Giacomini Prof ${ }^{a}$ Orientadora 
9

Anexos

9.1

Anexo 1 - Decreto №. 5.591, de 13 de julho de 1905

Promulga a adesão do Brasil ao Acordo concluído em Paris entre várias Potências, em 18 de Maio de 1904, para a repressão do tráfico de mulheres brancas.

\section{O Presidente da República dos Estados Unidos do Brasil:}

Havendo sido feita em Paris, no dia 12 de Maio do corrente ano, a declaração, por parte do Brasil, de aderir ao Acordo concluído naquela cidade entre várias Potências, em 18 de Maio de 1904, para a repressão do tráfico de mulheres brancas; e tendo o Congresso Nacional aprovado este ato internacional;

Declara:

Que o referido Acordo, apenso por tradução ao presente Decreto, seja observado e cumprido tão inteiramente como nele se contém, começando a ter execução em 18 de Julho corrente.

Rio de Janeiro, 13 de Julho de 1905, 17: da República.

FRANCISCO DE PAULA RODRIGUES ALVES

\section{ACORDO PARA A REPRESSÃo AO TRÁFICO DE MULHERES BRANCAS}

Art. 1. Cada um dos Governos contratantes só obriga a nomear ou designar uma autoridade encarregada de reunir todos os dados relativos ao aliciamento de mulheres virgens ou não, com o fim de prostituí-las no estrangeiro. Esse funcionário terá a faculdade de corresponder-se diretamente com a repartição similar estabelecida em cada um dos outros Estados contratantes.

Art. 2. Cada um dos Governos se obriga a estabelecer um serviço de vigilância tendo por fim descobrir, especialmente nas estações de caminhos de ferro, portos de embarque e viagens, os indivíduos incumbidos de acompanhar as mulheres, virgens ou não, que são destinadas à prostituição. 
A chegada de pessoas que pareçam evidentemente ser autores, cúmplices ou vítimas de semelhante tráfico, será comunicada, dado o caso, quer às autoridades do lugar de destino, quer aos agentes diplomáticos ou consulares interessados, quer ainda a quaisquer outras autoridades competentes.

Art. 3. Os governos se obrigam a mandar receber, quando assim acontecer e dentro dos limites legais, as declarações das mulheres, virgens ou não, de nacionalidade estrangeira, que se entreguem à prostituição, no sentido de determinar sua identidade e estado civil, e indagar quem as induziu a abandonar seu país. As informações recolhidas serão comunicadas às autoridades do país de origem de ditas mulheres, virgens ou não, para facilitar sua eventual repatriação.

Os governos se obrigam, dentro dos limites legais e tanto quanto possível, a confiar, a título provisório, e tendo em vista a eventual repatriação, a instituições de assistência pública ou privada ou a particulares que ofereçam as necessárias garantias às vítimas desse tráfico, quando elas se achem desprovidas de recursos.

Os Governos se obrigam igualmente, dentro dos limites legais e na medida do possível, a repatriar aquelas das mulheres, virgens ou não, que o solicitarem ou que vierem a ser reclamadas pelas pessoas que sobre elas tenham autoridade. A repatriação só será após acordo quando a identidade e a nacionalidade, bem como quanto ao lugar e à data de chegada à fronteira. Cada um dos países contratantes facilitará o respectivo trânsito no seu território.

A correspondência relativa às repatriações far-se-ão, tanto quanto possível, por via direta.

Art. 4. Quando a mulher, virgem ou não, que se tenha de repatriar, não poder indenizar por si mesma as despesas de seu transporte e não tenha nem marido, nem pais, nem tutor que o possam fazer, tais despesas correrão por conta do país em cujo território ela resida, até a fronteira próxima ou porto de embarque com destino ao país de origem, e por conta deste, todas as mais.

Art. 5 As convenções particulares, que por ventura existam entre os governos contratantes, não ficarão revogadas pelas disposições dos artigos 3e 4 do presente Acordo.

Art. 6 Os governos contratantes se obrigam, dentro dos limites legais, a exercer, tanto quanto possível, vigilância sobre as agências que se ocupam da colocação de mulheres, virgens ou não, no estrangeiro.

Art. 7o É permitido aos Estados não signatários, aderir ao presente Acordo. Para isso, notificarão sua intenção, por via diplomática, ao Governo Francês, que dela dará conhecimento a todos os Estados contratantes. 
Art. 8O presente Acordo entrará em vigor seis meses após a data da troca das ratificações.

No caso de ser denunciado por uma das partes contratantes, essa denúncia só produzirá efeitos quanto a ela se somente doze meses após o dia da dita denúncia.

Art. 9॰ O presente Acordo será ratificado e as ratificações serão trocadas em Paris, no mais breve prazo possível.

Em fé de que, os respectivos plenipotenciários assinarão o presente Acordo e nele porão seus selos. Feito em Paris a 18 de maio de 1904, em um só exemplar, que ficará depositado nos arquivos dos Negócios Estrangeiros da República Francesa, e do qual será entregue a cada potência contratante uma cópia autenticada.

\section{2 \\ Anexo 2 - Convenção Internacional para a supressão do tráfico de escravas brancas, assinada em Paris em 04 de maio de 1910, e emendada pelo protocolo assinado em Lake Success, Nova lorque, em 04 de maio de 1949}

International Convention for the suppression of the White Slave Traffic, signed at Paris on 4 may 1910, and as Amended by the Protocol signed at Lake Success, New York, 4 May 1949.

\section{Article 1}

Any person who, to gratify the passions of others, has hired, abducted or enticed, even with the consent, a woman or a girl who is a minor, for immoral purposes, even when the various acts which together constitute the offence were committed in different countries, shall be punished.

\section{Article 2}

Any person who, to gratify the passions of others, has by fraud or by the use of violence, threats, abuse of authority, or any other means of constraint, hired, abducted or enticed a woman or a girl of full age for immoral purposes, even when the various acts which together constitute the offence were committed in different countries, shall be punished.

\section{Article 3}

The contracting Parties undertake, if their legislation is not at present adequate to punish the offences mentioned in the two preceding articles, to take or to propose to their respective legislatures, the necessary measures to punish such offences in accordance with their gravity. 


\section{Article 4}

The Contracting parties shall communicate to each other, through the Secretary-General of the United Nations, such laws as have already been, or may in the future be, promulgated in their countries relating to the subject of the present Convention.

\section{Article 5}

The offences mentioned in articles 1 and 2 shall, as from the day on which the present Convention comes into force, be deemed ipso facto to be included among the offences giving cause for extradition according to already existing Conventions between the Contracting Parties.

In cases where effect cannot be given to be above stipulation without changing existing legislation, the Contracting Parties agree to take, or to propose to their respective legislatures, the necessary measures.

\section{Article 6}

The transmission of rogatory commissions relating to the offences covered by the present

Convention shall take place:

1 - Either by direct communication between the judicial authorities;

2- Or through the diplomatic or consular agent of the country making the application in the country to which application is made; that agent shall send the rogatory commission direct to the competent judicial authority and shall receive direct from that authority the documents showing that the rogatory commission has been carried out;

(In both the above cases, a copy of the rogatory commission shall always be sent at the same time to the superior authority of the State to which application is made);

\section{3- Or through the diplomatic channel.}

Each Contracting Party shall state, by means of a communication sent to each of the other Contracting Parties, which of the above-mentioned methods of transmission it accepts for rogatory commissions coming from that State.

All difficulties which may arise in connection with transmissions affected under (1) and (2) of the present article shall be settled through the diplomatic channel.

Unless there is agreement to the contrary, the rogatory commission must be drawn up either in the language of the authority to which application is made, or in the language agreed upon between the two States concerned, or it must be accompanied by a translation in one of those two languages, certified as authentic by a diplomatic or consular agent of the State to which application is made. 
No charges or expenses of any kind shall be refunded in respect of the execution of rogatory commission.

\section{Article 7}

The Contracting parties undertake to communicate to each other notification of sentence in the case of offences covered by the present Convention the constituent acts of which have been committed in different countries. These documents shall be transmitted direct by the authorities appointed in accordance with article 1 of the Agreement concluded in Paris on 18 May 1904, to the similar authorities of the other Contracting States.

\section{Article 8}

Non-signatory States may accede to the present Convention. For this purpose, they shall notify their intention by an instrument which shall be deposited in the archives of the United Nations. The Secretary-General of the United Nations shall send a certified copy to each of the Contracting States and to all the Members of the United Nations, and shall at the same time inform them of the date of deposit. The said instrument of notification shall also transmit any laws promulgated by the acceding State relating to the subject of the present Convention.

Six months after the date of deposit of the instrument of notification, the Convention shall come into force in the whole territory of the acceding State, which shall thus become a Contracting State.

Accession to the Convention shall entail ipso facto, and without special notification, simultaneous and complete accession to the Agreement of 18 May 1904, which shall come into force, on the same date as the Convention itself, in the whole territory of the acceding State.

The above provision shall, however, be without prejudice to article 7 of the aforesaid Agreement of 18 May 1904, which remains applicable in cases where a State may prefer to accede to that Agreement only.

\section{Article 9}

The present Convention, supplemented by a Final Protocol which forms an integral part thereof, shall be ratified and the ratifications shall be deposited at Paris, as soon as six of the Contracting States are in a position to do so.

There shall be established for every deposit of ratification a Protocol, of which a certified true copy shall be transmitted through the diplomatic channel to each of the Contracting States.

The present Convention shall come into force six months after the date of deposit of the ratifications. 


\section{Article 10}

Should one of the Contracting States denounce the Convention, such enunciation shall take effect only in respect of such State.

The denunciation shall be notified by an instrument which shall be deposited in the archives of the United Nations. The Secretary-General of the United Nations shall send a certified copy to each of the Contracting States and to all the Members of the United Nations, and shall at the same time inform them of the date of deposit.

The denunciation of the Convention shall cease to be in force in the whole territory of the State which has denounced it.

The denunciation of the Convention shall not ipso facto entail simultaneous denunciation of the Agreement of 18 May 1904, unless that is expressly mentioned in the instrument of notification; otherwise, the Contracting State must, in order to denounce the said Agreement, proceed in accordance with article 8 of that Agreement.

\section{Article 11}

Should a Contracting State desire the present Convention to come into force in one or more of its colonies, possessions or areas under consular jurisdiction, it shall for this purpose notify its intention by an instrument which shall be deposited in the archives of the United Nations. The Secretary-General of the United Nations shall send a certified copy to each of the contracting States and to all the Members of the United Nations, and shall at the same time inform them of the date of deposit.

The said instrument of notification, for such colonies, possessions or areas under consular jurisdiction, shall also transmit any laws promulgated relating to the subject of the present Convention. Such laws as may subsequently be promulgated shall similarly be notified to the Contracting States, in accordance with article 4.

Six months after the date of deposit of the instrument of notification, the Convention shall come into force in the colonies, possessions or areas under consular jurisdiction to which the instrument of notification refers.

The State making application shall signify, by means of a communication sent to each of the other Contracting States, which of the abovementioned methods of transmission it accepts for rogatory commission to the colonies, possessions or areas under consular jurisdiction covered by the notification mentioned in the first paragraph of the present article.

The denunciation of the Convention by one of the Contracting States, for one or more of such colonies, possessions or areas under consular jurisdiction shall take place in accordance with the forms and conditions laid down in the first paragraph of the present article. It shall take effect twelve months after the date of deposit of the instrument of denunciation in the archives of the United Nations. 
Accession to the Convention by a Contracting State in respect of one or more of its colonies, possessions or areas under consular jurisdiction shall entail, ipso facto, and without special notification simultaneous and complete accession to the Agreement of 18 May 1904. The said Agreement shall come into force there on the same date as the Convention itself. However, the denunciation of the Convention by a Contracting State in respect of one or more of its colonies, possessions or areas under consular jurisdiction shall not, ipso facto, entail, unless expressly mentioned in the instrument of notification, simultaneous denunciation of the Agreement of 18 May 1904. Further, such declarations as the Powers signatory to the Agreement of 18 May 1904 may have made with regard to the

accession of their colonies to the said Agreement remain valid.

Nevertheless, as from the date of the entry into force of the present Convention, accessions or denunciations in respect of this Agreement relating to the colonies, possessions or areas under consular jurisdiction of the Contracting State, shall be effected in accordance with the provisions of the present article.

\section{Article 12}

The present Convention, which shall bear the date of 4 May 1910, may be signed in Paris up to 31 July next by the Plenipotentiaries of the Powers represented at the Second Conference on the Suppression of the White Slave Traffic.

DONE in Paris on the fourth day of May, one thousand nine hundred and ten, in a single text, of which a certified true copy shall be delivered to each of the signatory Powers.

\section{A N N E X}

\section{FINAL PROTOCOL}

At the moment of proceeding to the signature of the Convention of today's date, theundersigned Plenipotentiaries deem it useful to indicate the spirit in which articles 1,2 and 3 of this convention are to be understood and in accordance with which it is desirable that, in the exercise of their legislative sovereignty, the Contracting States should provide for the implementation of the stipulations which have been agreed to or for their completion.

A. The provisions of article 1 and 2 must be regarded as minimum in the sense that the Contracting Governments naturally remain absolutely free to punish other similar offences such as the hiring of persons of full age even where there is no deceit or constraint.

B. For the punishment of the offences mentioned in articles 1 and 2, it is agreed that the words "a woman or a girl who is a minor, a woman or a girl of full age" mean women or girls, who are either above or bellow twenty years of age. A law may, however, establish a higher age for protection on condition that it is the same for women and girls of every nationality. 
C. For the punishment of the same offences, the law must provide, in all cases, for a sentence of imprisonment, without prejudice or any other main or accessory penalties; it must also take into account, independently of the age of the victim, the various aggravating circumstances which may have bearing on the particular case, such as those mentioned in article 2 or the fact that the victim had in fact been given over to immoral practices

D. The case of retention, against her will, of a woman or girl in a house of prostitution could not, in spite of its gravity, be included in the present Convention, because it is exclusively a question of internal legislation.

The present Final protocol shall be considered as forming an integral part of the Convention of today's date and shall have the same force, value and duration.

DONE and SIGNED in a single text, in Paris, on 4 May 1910.

\section{3 \\ Anexo 3 - Convenção Internacional para a Repressão ao Tráfico de mulheres e de crianças, de 30 de setembro de 1921}

L'ALBANIE, I'ALLEMAGNE, Lautriche, LA belgique, LE brésil, L'empire britannique (avec le CANADA, le COMMONWEALTH D'AUSTRALIE, I'UNION SUDAFRICAINE, la NOUVELLE-ZÉLADE et I'INDE), CHILI, CHINE, COLOMBIE,

COSTA-RICA, CUBA, I'ESTONIA, la GRÈCE, la HONGRIE, I'ITALIE, le JAPON, la LATVIE, la LITHUANIE, la NORVÈGE, les PAYS-BAS, la PERSE, la POLOGNE (avec DANTZIG), le PORTUGAL, la ROUMANIE, le SIAM, la SUĖDE, la SUISSE et la TCHÉCOSLOVAQUIE,

Désireux d'assurer d'une manière plus complète la repression de la traite des femmes et des enfants désignée dans les préambules de l'Arrangement du 18 mai 1904 et de la Convention du 4 mai 1910 sous le nom de "Traite des Blanches",

Ayant pris connaissances des recommandations inscrites à l'Acte final de la Conférence internationale qui s'est reunie à Genève, sur convocation du Conseil de la Société des Nations, du 30 juin au 5 juillet 1921; et Ayant décidé de conclure une Convention additionnelle à l'Arrangemente et à la Convention ci-dessus mentionnés:

(...)

Lesquels, après avoir communiqué leurs pleins pouvoirs reconnus en bonne et due forme, ont convenu des dispositions suivantes: 


\section{Article 1}

Les Hautes Parties Contractantes conviennent, pour autant qu'elles ne seraient pas encore Parties à l'Arrangement du 18 mai 1904 et à la Convention du 4 mai 1910, de transmettre, dans le plus bref délai et dans la forme prevue aux Arrangement et Convention ci-dessus vises, leurs ratifications desdits Actes ou leurs adhesions auxdits Actes.

\section{Article 2}

Les Hautes Parties Contractantes conviennent de prendre toutes measures en vue de rechercher et de punir les individus qui se livrent à la traite des enfants del'un et de l'autre sexe, cette infraction étant entendue dans le sens de l'article premier de la Convention du 4 mai 1910.

\section{Article 3}

Les Hautes Parties Contractantes conviennent de prenre les measures nécessaires en vue de punir les tentatives d'infractions et, dans les limites légales, les actes preparatoires des infractions prévues aux articles 1 at 2 de la Convention du 4 mai 1910.

\section{Article 4}

Les Hautes Parties Contractantes conviennent, au cas ou il n'existerait pas entre elles de Conventions d'extradition, de prendre toutes les mesures qui sont en leur pouvoir pour l'extradition des individus prévenus des infractions vesées aux articles 1 et 2 de la Convention du 4 mai 1910, ou condamnés pour de telles infractions.

\section{Article 5}

Au paragraphe B du protocole final de la Convencion de 1910, les mots "vingt ans révolus" seront remplacés par les mots "vingnt et un ans révolus".

\section{Article 6}

Les Hautes Parties Contractantes conviennent, dans le cas où elles n'auraient pas encore pris de mesures lágislatives ou administratives concernant l'autorisation et la surveillance des agences et des bureaux de placement, d'édicter des règlements dans ce sens afin d'assurer la protection des femmes et des enfants cherchant du travail dans unautre pays.

\section{Article 7}

Les Hautes Parties Contractantes conviennent, en ce qui concerne leurs services

d'immigration et d'emigration, de prende des mesures administratives et législatives destinées à combattre la traite des femmes et des enfants. Elles conviennent notamment d'édicter les règlements nécessaires pour la protection des femmes et des enfants voyageant à bord des navires d'emigrants, non seulement au départ et à l'arrivée, mais aussi en cours de route, et à prendre des dispositions en vue de l'affichage, dans les gares et dans les ports, d'avis mettant en garde les femmes et les enfants contre les dangers de la traite et indiquant 
les lieux où ils peuvent trouver logement, aide et assistance.

\section{Article 8}

La présent Convention, dont le texte français et le texte anglais font également foi, portera la date de ce jour et pourra être signée jusqu'au 31 mars 1922.

\section{Article 9}

La présente Convention est sujette à ratification. Les instruments de ratifications seront transmis au Secrétaire géneral dela Société des Nations, qui en notifiera la réceptios aux autres Membres de la Société et aux Etats admis à signer la Convention. Les instruments de ratification seront déposés aux archives du Secrétariat.

Conformément aux dispositions de l'article 18 du Pacte de la Société des Nations, le Secrétaire général enregistrera la présente Convention dès que le dépôt de la première ratification aura été effectué.

\section{Article 10}

Les Membres de la Société des Nations n'ayant pas signé la présente Convention avant le 1er avril 1922 pourront y adhérer.

II en sera de même des Etats non Membres de la Société auxquels le Conseil de la Société pourra décider de communiquer officiellement la présente Convention.

Les adhésions seront notifiées au Secrétaire général de la Société, qui en avisera toutes les Puissances inéressées, en mentionnant la date de la notification.

\section{Article 11}

La présente Convention entrera en vigueur, pour cheque, partie, à la date du dépôt de sa ratification ou de son acte d'adhésion.

\section{Article 12}

La présente Convention pourra être dénoncée par tout Membre de la Société ou Etat, partie à ladite Convention, en donnant un préavis de douze mois. La dénonciation sera effectué par une notification écrite adressée au Secrétaire général de la Société. Celui-ci transmettra immédiatement a toutes les autres Parties des exemplaires de cette notification en indiquant la date de réception.

La dénonciation prendra effet un an après la date de notification au Secrétaire général et ne sera valable que pour l'Etat qui l'aura notifiée.

\section{Article 13}

Le Secrétaire général de la Société tiendra une liste de toutes les Parties qui ont signé, ratifi', ou dénoncé la presente Convention où y ont adhéré. Cette liste pourra être, en tout temps, consultée par les Membres de la Société; il en sera donné publication aussi souvent que possible, suivant les instructions du Conseil. 


\section{Article 14}

Tout Membres ou Etat signataire peut déclarer que sa signature n'engage pas soit l'ensemble, soit telle de ses colonies, possessions d'outre-mer, protectorats ou territoires soumis à as souveraineté où à son autotité, et peut, ultérienrement, adhérer séparément au nom de l'une quelconque de ses colonies, possessions d'outre-mer, protectorats où territoires exclus par cette déclaration.

La dénonciation pourra également s'effectuer séparément pour toute colonie, possession d'outre-mer, protectorat ou territoire soumis à sa souveraineté ou autorité; les dispositions de l'article 12 s'appliqueront à cette dénonciation.

Fait a GENÈVE, le trente Septembre mil neuf cent vingt et un, en un seul exemplaire, qui reste déposé aux archives de la Société des Nations.

\section{4}

Anexo 4 - Protocolo de Emenda da Convenção para a Repressão do Tráfico de Mulheres e Crianças, concluída em Genebra, a 30 de setembro de 1921, e da Convenção para a Repressão do Tráfico DE Mulheres maiores, concluída em Genebra, a 11 de outubro de 1933

Os Estados Partes no presente Protocolo, considerando que a Convenção para a Repressão do Tráfico de Mulheres e Crianças, concluída em Genebra, a 30 de setembro de 1921, e a Convenção para a Repressão do Tráfico de Mulheres Maiores, concluída em Genebra, a 11 de outubro de 1933, confiaram à Liga das Nações certos poderes e funções, e que, em face da dissolução da Liga das Nações, é necessária a adoção de medidas com o fim de assegurar o exercício contínuo desses poderes e funções, e considerando que é oportuno que eles sejam assumidos, doravante, pela Organização das Nações Unidas, convieram no seguinte:

\section{Artigo I}

Os Estados Partes no presente Protocolo assumem o compromisso, entre si, cada qual no que diz respeito aos instrumentos nos quais é Parte, e de acordo com as disposições do presente Protocolo, de atribuir pleno valor jurídico às emendas aos mencionados instrumentos contidas no Anexo ao presente Protocolo, de as por em vigor e de assegurar sua aplicação.

\section{Artigo II}

O Secretário Geral preparará o texto das Convenções revistas de conformidade com o presente Protocolo e transmitirá, a título informativo, cópias do mesmo ao Governo de cada Membro da Organização das 
Nações Unidas, bem como ao Governo de cada Estado não membro, à assinatura ou aceitação de qual fica o presente Protocolo aberto. Convidará igualmente as Partes em qualquer dos instrumentos emendados pelo presente Protocolo a aplicar os textos emendados desses instrumentos logo que entrarem em vigor essas emendas, mesmo se não se tiverem ainda tornado Partes no presente Protocolo.

\section{Artigo III}

O presente Protocolo ficará aberto à assinatura ou à aceitação de todos os Estados Partes na Convenção de 30 de setembro de 1921 para a Repressão do Tráfico de mulheres e Crianças ou na Convenção de 11 de outubro de 1933 para a Repressão do Tráfico de Mulheres Maiores, aos quais o Secretário Geral houver transmitido cópia do presente Protocolo.

\section{Artigo IV}

Os Estados poderão tornar-se Partes no presente Protocolo:

a) pela assinatura sem reserva quanto à aprovação; ou

b) pela aceitação; a aceitação se efetuará pelo depósito de um instrumento formal junto ao Secretário Geral da Organização das Nações Unidas.

\section{Artigo V}

1. O presente Protocolo entrará em vigor na data na qual dois ou mais Estados se tornarem Partes no mencionado Protocolo.

2. As emendas contidas no Anexo ao presente Protocolo entrarão em vigor, no que diz respeito a cada Convenção, desde que a maioria das Partes na Convenção se tenham tornado Partes no presente Protocolo e, em conseqüência, todo Estado que se tornar Parte em uma ou outra das Convenções, após a entrada em vigor das emendas que à mesma se referem, se tornará Parte na Convenção assim emendada.

\section{Artigo VI}

De acordo com o parágrafo primeiro do Artigo 102 da Carta das Nações Unidas e com o regulamento adotado pela Assembléia Geral para a aplicação desse texto, o Secretário Geral da Organização das Nações Unidas fica autorizado a registrar o presente Protocolo bem como as emendas feitas em cada Convenção pelo presente Protocolo, nas respectivas datas de sua entrada em vigor, e a publicar o Protocolo e as Convenções emendadas logo que possível após seu registro.

\section{Artigo VII}

O presente Protocolo, cujos textos chinês, inglês, francês e espanhol são igualmente autênticos, será depositado nos arquivos do Secretariado da Organização das Nações Unidas. Considerando que as Convenções emendadas, de acordo com o Anexo, estão redigidas apenas em inglês e em francês, os textos inglês e francês do Anexo serão igualmente autênticos, e os textos chinês, russo e espanhol serão traduções.

Uma cópia autenticada do Protocolo, com o Anexo, será enviada pelo Secretário Geral a cada um dos Estados Partes na Convenção de 30 de 
setembro de 1921 para a repressão do tráfico de mulheres e crianças ou na Convenção de 11 de outubro de 1933 para a repressão do tráfico de mulheres maiores, bem como a todos os Membros da Organização das NaçõesUnidas.

EM FÉ DO QUE, os abaixo-assinados, devidamente autorizados pelos seus respectivos Governos, assinaram o presente Protocolo, na data que figura junto a suas respectivasassinaturas.

FEITO em Lake Success, Nova York, a doze de novembro de mil novecentos e quarenta e sete.

\section{ANEXO AO PROTOCOLO DE EMENDA DA CONVENÇÃO PARA A REPRESSÃO DO TRÁFICO DE MULHERES E CRIANÇAS, CONCLUÍDA EM}

GENEBRA, A 30 DE SETEMBRO DE 1921, E DA CONVENÇÃO PARA A REPRESSÃO DO TRÁFICO DE MULHERES MAIORES, CONCLUÍDA EM GENEBRA, A 11 DE OUTUBRO DE 1933.

\section{Convenção Internacional para a Repressão do Tráfico de Mulheres e}

crianças, aberta à assinatura, em Genebra, a 30 de setembro de 1921.

O parágrafo primeiro do Artigo 9 ficará assim redigido:

A presente Convenção estará sujeita a ratificação. A partir de $1^{\circ}$ de janeiro de 1948, os instrumentos de ratificação serão transmitidos ao Secretário Geral da Organização das Nações Unidas, que notificará o recebimento dos mesmos aos Membros da Organização das Nações Unidas e aos Estados não-membros aos quais houver enviado cópia da Convenção. Os instrumentos de ratificação serão depositados nos arquivos do Secretariado da Organização das Nações Unidas.

O Artigo 10 ficará assim redigido:

Os membros da Organização das Nações Unidas poderão aderir à presente Convenção.

O mesmo se aplica aos Estados não-membros aos quais o Conselho Econômico e Social das Nações Unidas resolver comunicar oficialmente a presente Convenção.

As adesões serão notificadas ao Secretário Geral da Organização das NaçõesUnidas, que as comunicará a todos os Estados Membros, bem como aos Estados não membros aos quais houver enviado cópia da Convenção.

O Artigo 12 ficará assim redigido:

Todo Estado Parte na presente Convenção poderá denunciá-la, mediante um aviso prévio de doze meses. 
A denúncia será feita por uma notificação escrita ao Secretário Geral da Organização das Nações Unidas, o qual transmitirá imediatamente cópias da mesma, com a data de seu recebimento, a todos os Membros da Organização das Nações Unidas e aos Estados não-membros, aos quais houver enviado cópia da Convenção. A denúncia vigorará após um ano a contar da data da notificação ao Secretário Geral da Organização das Nações Unidas e só valerá com relação ao Estado que a tiver efetuado.

O Artigo 13 ficará assim redigido:

O Secretário Geral da Organização das Nações Unidas manterá uma relação especial de todas as Partes que assinaram, ratificaram ou denunciaram a presente Convenção, ou aderiram à mesma. Essa relação poderá ser consultada a qualquer tempo, por qualquer Membro da Organização das Nações Unidas ou por qualquer Estado não membro ao qual o Secretário Geral houver enviado uma cópia da Convenção e será publicada o mais freqüente possível, de acordo com as instruções do Conselho Econômico e Social da Organização das Nações Unidas.

O Artigo 14 será suprimido.

2. Convenção Internacional para a Repressão do Tráfico de Mulheres Maiores, assinada em Genebra, a 11 de outubro de 1933.

No Artigo 4, as palavras "Corte Internacional de Justiça" substituirão as palavras "Corte Permanente de Justiça Internacional", e as palavras "ao Estatuto da Corte Internacional de Justiça" as palavras "ao Protocolo de 16 de dezembro de 1920, relativo ao Estatuto da mencionada Corte".

O Artigo 6 ficará assim redigido:

A presente Convenção será ratificada. A partir de $1^{\circ}$ de janeiro de 1948 , os instrumentos de ratificação serão transmitidos ao Secretário Geral da Organização das Nações Unidas, que notificará o depósito dos mesmos a todos os Membros da Organização das Nações Unidas e aos Estados não-membros aos quais houver enviado cópia da Convenção.

O Artigo 7 ficará assim redigido:

Os Membros da Organização das Nações Unidas poderão aderir à presente Convenção. O mesmo se aplica aos Estados não-membros aos quais o Conselho

Econômico e Social da Organização das Nações Unidas resolver comunicar oficialmente a presente Convenção.

Os instrumentos de adesão serão transmitidos ao Secretário Geral da Organização das Nações Unidas, que notificará o depósito dos mesmos a 
todos os Estados Membros, bem como aos Estados não-membros aos quais o Secretário Geral houver enviado cópia da Convenção.

No Artigo 9, as palavras "Secretário geral da Organização das Nações Unidas" substituirão as palavras "Secretário Geral da liga das Nações".

No Artigo 10, os três primeiros parágrafos serão suprimidos e o parágrafo quarto ficará assim redigido:

O Secretário Geral comunicará as denúncias previstas no Artigo 9 a todos os Membros da Organização das Nações Unidas bem como aos Estados não-membros aos quais houver enviado cópia da Convenção.

\section{5}

Anexo 5 - Decreto $N^{\circ} 46.981$, de 8 de Outubro de 1959.

Promulga, com 0 respectivo Protocolo Final, a Convenção para a Repressão do Tráfico de Pessoas e do Lenocínio, concluída em Lake Success, Nova lorque, em21 de março de 1950, e assinada pelo Brasil em 5 de outubro de 1951.

O PRESIDENTE DA REPÚBLICA, havendo o Congresso Nacional aprovado, pelo Decreto Legislativo $\mathrm{n}^{\circ} 6$, de 11 de junho de 1958, com o respectivo Protocolo Final, a convenção para a repressão do tráfico de pessoas e do lenocínio, concluída em Lake Success, em 21 de março de 1950, e assinada pelo Brasil em 5 de outubro de 1951; e tendo sido depositado, a 12 de setembro de 1958, junto ao Secretário Geral da Organização das Nações Unidas, o instrumento brasileiro de ratificação da referida Convenção e seu Protocolo Final:

\section{DECRETA:}

Que a mencionada Convenção e respectivo Protocolo Final, apensos por cópia ao presente Decreto, sejam executados e cumpridos tão inteiramente como neles se contém.

Rio de Janeiro, em 8 de outubro de $1959 ; 138^{\circ}$ da Independência e $71^{\circ}$ da República. 


\section{CONVENÇÃO PARA A REPRESSÃO DO TRÁFICO DE PESSOAS E DO LENOCÍNIO}

PREÂMBULO

CONSIDERANDO que a prostituição e o mal que a acompanha, isto é, o tráfico de pessoas para fins de prostituição, são incompatíveis com a dignidade e o valor da pessoa humana e põem em perigo o bem-estar do indivíduo, da família e da comunidade;

CONSIDERANDO que, com relação à repressão do tráfico de mulheres e crianças estão em vigor os seguintes instrumentos internacionais:

1. Acordo Internacional de 18 de maio de 1904 para a repressão do tráfico de mulheres brancas, emendado pelo Protocolo aprovado pela Assembleia Geral das Nações Unidas a 3 de dezembro de 1948.

2. Convenção Internacional de 4 de maio de 1910, relativa à repressão do tráfico de mulheres brancas, emendada pelo Protocolo acima mencionado.

3. Convenção internacional de 30 de setembro de 1921 para a repressão do tráfico das mulheres e crianças, emendada pelo Protocolo aprovado pela Assembleia Geral das Nações Unidas a 20 de outubro de 1947.

4. Convenção Internacional de 11 de outubro de 1933relativa à repressão do tráfico de mulheres maiores emendada pelo Protocolo acima referido;

CONSIDERANDO que a Liga das Nações havia elaborado em 1937 um projeto de Convenção para ampliar o campo de ação dos aludidos instrumentos e

CONSIDERANDO que a evolução ocorrida depois de 1937 permite concluir uma convenção que unifique os instrumentos acima mencionados e inclua o essencial do projeto da Convenção de 1937, com as emendas que se julgou conveniente introduzir;

\section{EM CONSEQUÊNCIA, AS PARTES CONTRATANTES CONVÊM NO SEGUINTE:}

\section{Artigo 1}

As partes na presente Convenção convêm em punir toda pessoa que, para satisfazer às paixões de outrem:

1. ampliar, induzir ou desencaminhar para fins de prostituição, outra pessoa, ainda que com seu consentimento; 
2. explorar a prostituição de outra pessoa, ainda que com seu consentimento.

\section{Artigo 2}

As partes na presente Convenção convêm igualmente em punir toda pessoa que:

1. mantiver, dirigir ou, conscientemente, financiar uma casa de prostituição ou contribuir para esse financiamento;

2. conscientemente, der ou tomar de aluguel, total ou parcialmente, um imóvel ou outro local, para fins de prostituição de outrem.

\section{Artigo 3}

Deverão ser também punidos, na medida permitida pela legislação nacional, toda tentativa e ato preparatório efetuados com o fim de cometer as infrações de que tratam os Artigos 1 e 2.

\section{Artigo 4}

Será também punível na medida permitida pela legislação nacional, a participação

intencional nos atos de que tratam os Artigos 1 e 2 acima.

Os atos de participação serão acima considerados, na medida permitida pela legislação nacional como infrações distintas, em todos os casos em que for necessário assim proceder para impedir a impunidade.

\section{Artigo 5}

Em todos os casos em que uma pessoa ofendida for autorizada pela legislação nacional a se constituir parte civil por causa de qualquer das infrações de que trata a Presente Convenção, os estrangeiros estarão igualmente autorizados a se constituir parte civil, em igualdade de condições, com os nacionais.

\section{Artigo 6}

Cada Parte na presente Convenção convém em adotar todas as medidas necessárias para ab-rogar ou abolir toda lei, regulamento e prática administrativa que obriguem a inscrever-se em registros especiais, possuir documentos especiais ou conformar-se a condições excepcionais de vigilância ou de notificação as pessoas que se entregam ou que supõem entregar-se à prostituição.

Qualquer condenação anterior pronunciada em Estado estrangeiro por um dos atos de que trata a Convenção, será, na medida permitida pela legislação nacional, tomada em consideração:

1. para estabelecer a reincidência;

2. para declarar incapacidades, perda ou interdição de direito público ou privado. 


\section{Artigo 8}

Os atos de que tratam os Artigos 1 e 2 da presente Convenção serão considerados como casos de extradição, concluídos ou por concluir, entre Partes na presente Convenção.

As partes na presente Convenção, que não subordinem a extradição à existência de um tratado, reconhecerão de agora em diante os atos de que convençam como casos de extradição entre elas.

A extradição será concedida de acordo com o direito do Estado ao qual foi requerida.

\section{Artigo 9}

Os nacionais de um Estado, cuja legislação não admitir a extradição de nacionais que regressaram a esse Estado após haver cometido no estrangeiro qualquer dos atos de que tratam os Artigos 1 e 2 da presente Convenção, deverão ser julgados e punidos pelos tribunais de seu próprio Estado.

Esta disposição não será obrigatória se, em caso análogo e que interessar a Partes na presente Convenção, não puder ser concedida a extradição de um estrangeiro.

\section{Artigo 10}

As disposições do Artigo 9 não se aplicarão quando o réu tiver sido julgado em um Estado estrangeiro e, em caso de condenação, se cumpriu a pena ou se gozou do benefício de comutação ou redução da pena prevista pela lei do referido Estado estrangeiro.

\section{Artigo 11}

Nenhuma das disposições da presente Convenção poderá ser interpretada como prejudicial à situação de uma parte na Convenção com referência à questão geral da competência da jurisdição penal em direito internacional.

\section{Artigo 12}

A presente Convenção não afeta o princípio de que todos os atos a que se refere deverão ,em cada Estado, ser qualificados, processados e julgados de acordo com a legislação nacional.

\section{Artigo 13}

As partes na presente Convenção serão obrigadas a executar as cartas rogatórias relativas às infrações de que trata a Convenção, de acordo com as leis e os costumes nacionais.

A transmissão de cartas rogatórias será efetuada:

1. por comunicação direta entre as autoridades judiciais; 
2. por correspondência direta entre os Ministros da Justiça dos dois Estados, ou por comunicação direta, de outra autoridade competente do Estado requerente ao Ministro da Justiça do Estado requerido;

3. por intermédio do representante diplomático ou consular do Estado requerente no Estado requerido; esse representante enviará diretamente as cartas rogatórias à autoridade judiciária competente ou à autoridade indicada pelo Governo do Estado requerido e dela receberá diretamente os documentos necessários à execução das cartas rogatórias.

Nos casos 1 e 3, uma cópia da carta rogatória deverá ser, na mesma ocasião, encaminhada à autoridade superior do Estado requerido.

Salvo acordo em contrário, a carta rogatória deverá ser redigida no idioma da autoridade requerente, ressalvando-se ao Estado requerido o direito de solicitar uma tradução em seu próprio idioma, devidamente autenticada pela autoridade requerente.

Cada Parte na presente Convenção comunicará a cada uma das outras Partes Contratantes a forma ou formas de transmissão dentre as acima mencionadas que admitirá para as cartas rogatórias da referida Parte.

Até que um Estado faça tal comunicação, o processo em vigor para cartas rogatórias será mantido.

A execução das cartas rogatórias não poderá ocasionar o reembolso de quaisquer direitos ou despesas, salvo as de perícia.

Nenhuma das disposições do presente Artigo deverá ser interpretada como compromisso das Partes na presente Convenção em admitir uma derrogação de suas leis, no que se refere ao processo e aos métodos empregados para estabelecer a prova em matéria penal.

\section{Artigo 14}

Cada uma das Partes na presente Convenção deverá criar e manter um serviço encarregado de coordenar e centralizar os resultados das investigações relativas às infrações de que trata a presente Convenção.

Esses serviços deverão reunir todas as informações que possam facilitar a prevenção e a repressão das infrações de que trata a presente Convenção e deverão manter estreitas relações com os serviços correspondentes dos demais Estados.

\section{Artigo 15}

As autoridades encarregadas dos serviços mencionados no Artigo 14 fornecerão às autoridades encarregadas dos serviços correspondentes nos demais Estados, na medida permitida pela Legislação nacional, quando julgarem útil, as seguintes informações:

1. dados pormenorizados relativos a qualquer infração ou tentativa de infrações de que trata a presente Convenção; 
2. dados pormenorizados relativos às investigações, processos, detenções, condenações, recusas de admissão ou expulsões de pessoas culpadas de qualquer das infrações de que trata a presente Convenção, bem como aos deslocamentos dessas pessoas e quaisquer informações úteis a respeito das mesmas.

As informações que serão fornecidas compreenderão notadamente a descrição dos delinquentes, suas impressões digitais e fotografia, indicações sobre os métodos habituais, autos policiais e registros criminais.

\section{Artigos 16}

As Partes na presente Convenção se comprometem a adotar medidas para a prevenção da prostituição e para assegurar a reeducação e readaptação social das vítimas da prostituição e das infrações de que trata a presente Convenção bem como a estimular a adoção dessas medidas por seus serviços públicos ou privados de caráter educativo sanitário, social, econômico e outros serviços conexos.

\section{Artigo 17}

No que se refere à imigração e emigração, as Partes na presente Convenção convêm em adotar ou manter em vigor, nos limites de suas obrigações definidas pela presente Convenção, as medidas destinadas a combater o tráfico de pessoas de um ou outro sexo para fins de prostituição.

Comprometem-se principalmente:

1. a promulgar os regulamentos necessários para a proteção dos imigrantes ou emigrantes, em particular das mulheres e crianças, quer nos lugares de partida e chegada quer durante a viagem;

2. a adotar disposições para organizar uma propaganda apropriada destinada a advertir o público contra os perigos desse tráfico;

3. a adotar medidas apropriadas para manter a vigilância nas estações ferroviárias, aeroportos, portos marítimos, em viagens e lugares públicos, a fim de impedir o tráfico internacional de pessoas para fim de prostituição;

4. a adotar as medidas apropriadas para que as autoridades competentes estejam ao corrente da chegada de pessoas que pareçam "prima facie" culpadas, coautoras ou vítimas desse tráfico.

\section{Artigo 18}

As Partes na presente Convenção convêm em tomas de acordo com as condições estipuladas pelas respectivas legislações nacionais, as declarações das pessoas de nacionalidade estrangeiras que se entregam à prostituição, a fim de estabelecer sua identidade e estado civil e 
procurar quem as induziu a deixar seu Estado. Tais informações serão comunicadas às autoridades de Estado de origem das referidas pessoas para eventual repatriação.

\section{Artigo 19}

As Partes na presente Convenção se comprometem, conforme as condições estipuladas pelas respectivas legislações nacionais, sem prejuízo de processos ou de qualquer outra ação motivada por infrações a suas disposições e tanto quanto possível:

1. A tomar as medidas apropriadas para prover as necessidades e assegurar a manutenção, provisoriamente, das vítimas do tráfico internacional para fins de prostituição, quando destituídas de recursos, até que sejam tomadas todas as providências para repatriação;

2. Ao repatriar as pessoas de que trata o artigo 18, que o desejarem ou que forem

reclamadas por pessoas que sobre elas tenham autoridade e aquelas cuja expulsão foi decretada conforme a lei. A repartição não será efetuada senão depois de entendimento com o Estado de destino, sobre a identidade e a nacionalidade, assim como sobre o lugar e a data da chegada às fronteiras. Cada uma das Partes na presente Convenção facilitará o trânsito das pessoas em apreço no seu território. Quando as pessoas de que trata a alínea precedente não puderem pessoalmente arcar com as despesas de repatriação e quando não tiverem cônjuges, nem parentes, nem tutor que pague, por elas, as despesas de repatriação estarão a cargo do Estado onde elas se encontram até a fronteira, porto de embarque ou aeroporto mais próximo na direção do Estado de origem, e, em seguida, a cargo do Estado de origem.

\section{Artigo 20}

As Partes na presente Convenção convém, se já não o fizeram, em adotar as medidas necessárias para exercer vigilância nos escritórios ou agência da colocação, para evitar que as pessoas que procuram emprego, especialmente as mulheres e crianças, fiquem sujeitas ao perigo da prostituição.

\section{Artigo 21}

As Partes na presente Convenção comunicarão ao Secretário Geral da Organização das Nações Unidas suas leis e regulamentos em vigor e posteriormente, cada ano, os novos textos de leis ou regulamentos relativos à matéria da presente Convenção, assim como todas as medidas que tomarem para aplicar a Convenção. As informações recebidas serão publicadas periodicamente pelo Secretário Geral e enviadas a todos os Membros da Organização das Nações unidas e aos Estados não membros aos quais a presente Convenção tiver sido oficialmente comunicada, de acordo com as disposições do Artigo 23.

\section{Artigo 22}

Se surgir entre as Partes na presente Convenção qualquer dúvida, relativa à sua 
interpretação ou aplicação, e se esta dúvida não puder ser resolvida por outros meios será, a pedido de qualquer das Partes em litígio, submetida à Corte Internacional de justiça.

\section{Artigo 23}

A presente Convenção será aberta a assinatura de todos os Estados Membros da

Organização das Nações Unidas e de qualquer outro Estado convidado para esse fim pelo Conselho Econômico e Social. Ela será ratificada e os instrumentos de ratificação serão depositados junto ao Secretário Geral da Organização das Nações Unidas.

Os Estados mencionados no parágrafo primeiro, que não assinaram a Convenção, poderão a ela aderir. A adesão se fará com o depósito de um instrumento de adesão junto ao Secretário Geral da Organização das Nações Unidas.

Para os fins da presente Convenção, a palavra "Estado" designará também todas as colônias e territórios sob tutela, dependentes do Estado que assina ou ratifica a Convenção, ou que a ela adere, assim como todos os territórios que este Estado represente no plano internacional.

\section{Artigo 24}

A presente Convenção entrará em vigor noventa dias depois da data do depósito do segundo instrumento de ratificação ou de adesão.

Para cada um dos Estados que ratificarem ou aderirem depois do depósito do segundo instrumento de ratificação ou adesão, ela entrará em vigor noventa dias depois do depósito por este Estado de seu instrumento de ratificação ou de adesão.

\section{Artigo 25}

Ao término do prazo de cinco anos a partir da entrada em vigor na presente Convenção, qualquer Parte na Convenção pode denunciá-la por notificação escrita endereçada ao Secretário Geral da Organização das nações Unidas.

A denúncia produzirá efeitos, para a Parte interessada, um ano depois de recebida pelo Secretário Geral da Organização das Nações Unidas.

\section{Artigo 26}

O Secretário Geral da Organização das Nações Unidas notificará a todos os Estados Membros da Organização das Nações Unidas e aos Estados não membros mencionados no Artigo 23

a) As assinaturas, ratificações e adesões recebidas nos termos do artigo 23;

b) A data da entrada em vigor da presente Convenção nos termos do artigo 24;

c) As denúncias recebidas nos termos do artigo 25 . 


\section{Artigo 27}

Cada uma das Partes na presente Convenção se compromete a tomar, conforme sua Constituição, as medidas legislativas ou outras, necessárias a assegurar a aplicação da Convenção.

\section{Artigo 28}

As disposições da presente Convenção anulam e substituem, entre as Partes, as disposições dos instrumentos internacionais mencionados nas alíneas 1, 2, 3 e 4 do segundo parágrafo do Preâmbulo; cada um deles será considerado caduco, quando todas as Partes neste instrumento se tornarem Partes na presente Convenção.

Em fé do que, os abaixo assinados, devidamente autorizados por seus Governos, assinaram a presente Convenção aberta à assinatura em Lake Success, Nova York, aos vinte e um de março de mil novecentos e cinqüenta, uma cópia da qual devidamente autenticada será enviada pelo secretário Geral a todos os Estados Membros da Organização das Nações Unidas e aos Estados não membros de que trata o artigo 23.

\section{PROTOCOLO FINAL}

Nenhuma das disposições da presente Convenção poderá ser interpretada em detrimento de qualquer legislação que, para a aplicação das disposições destinadas à supressão do tráfico internacional de pessoas e do lenocínio, preveja condições mais rigorosas do que as estipuladas na presente Convenção.

As disposições dos artigos 23 a 26, inclusive, da Convenção aplicar-se-ão ao presenteProtocolo.

A presente é tradução oficial, em idioma português, do texto original e autêntico da Convenção para a Supressão do Tráfico de Pessoas e do Lenocínio, e do respectivo Protocolo Final concluídos em Lake Success, Nova York, a 21 de março de 1950.

\section{6}

\section{Anexo 6 - Decreto № 5.017, de 12 de Março DE 2004}

Promulga o Protocolo Adicional à Convenção das Nações Unidas contra 0 Crime organizado Transnacional Relativo à Prevenção, Repressão e Punição do Tráfico de Pessoas, em Especial Mulheres e Crianças. 
O PRESIDENTE DA REPÚBLICA, no uso da atribuição que the confere o art. 84, inciso IV, da Constituição, e Considerando que o Congresso Nacional aprovou, por meio de Decreto Legislativo no 231, de 29 de maio de 2003, o texto do Protocolo Adicional à Convenção das Nações Unidas contra o Crime organizado Transnacional Relativo à Prevenção, Repressão e Punição do Tráfico de Pessoas, em Especial Mulheres e Crianças, adotado em Nova York em 15 denovembro de 2000;

Considerando que o Governo brasileiro depositou o instrumento de ratificação junto à Secretaria - Geral da ONU em 29 de janeiro de 2004;

Considerando que o Protocolo entrou em vigor internacional em 29 de setembro de 2003, e entrou em vigor para o Brasil em 28 de fevereiro de 2004;

\section{DECRETA:}

Art. $1^{\circ} \mathrm{O}$ Protocolo Adicional à Convenção das Nações Unidas contra o Crime organizado Transnacional Relativo à Prevenção, Repressão e Punição do Tráfico de Pessoas, em Especial Mulheres e Crianças, adotado em Nova York em 15 de novembro de 2000, apenso por cópia ao presente Decreto, será executado e cumprido tão inteiramente como nele se contém.

Art. $2^{\circ}$ São sujeitos à aprovação do Congresso Nacional quaisquer atos que possam resultar em revisão do referido Protocolo ou que acarretem encargos ou compromissos gravosos ao patrimônio nacional, nos termos do art. 49, inciso I, d Constituição.

Art. $3^{\circ}$ Este decreto entra em vigor na data de sua publicação.

Brasília, 12 de março de $2004 ; 183^{\circ}$ da Independência e $116^{\circ}$ da República.

LUIZ INÁCIO LULA DA SILVA

\section{PROTOCOLO ADICIONAL À CONVENÇÃO DAS NAÇÕES UNIDAS CONTRA O CRIME ORGANIZADO TRANSNACIONAL RELATIVO À PREVENÇÃO, REPRESSÃO E PUNIÇÃO DO TRÁFICO DE PESSOAS, EM ESPECIALMULHERES E CRIANÇAS}

\section{PREÂMBULO}

Os Estados partes deste Protocolo, Declarando que uma ação eficaz para prevenir e combater o tráfico de pessoas, em especial mulheres e crianças, exige por parte dos países de origem, de trânsito e de destino uma abordagem global e internacional, que inclua medidas destinadas a prevenir esse tráfico, punir os traficantes e proteger as vítimas desse tráfico, designadamente protegendo os seus direitos fundamentais, 
internacionalmente reconhecidos, Tendo em conta que, apesar da existência de uma variedade de instrumentos internacionais que contém normas e medidas para combater a exploração de pessoas, especialmente mulheres e crianças, não existe nenhum instrumento universal que trate de todos os aspectos relativos ao tráfico de pessoas,

Preocupados com o fato de na ausência desse instrumento, as pessoas vulneráveis ao tráfico não estarem suficientemente protegidas,

Recordando a Resolução 53/111 da Assembleia Geral, de 9 de Dezembro de 1998, na qual a Assembleia decidiu criar um comitê intergovernamental especial, de composição aberta, para elaborar uma convenção internacional global contra o crime organizado transnacional e examinar a possibilidade de elaborar, designadamente, um instrumento internacional de luta contra o tráfico de mulheres e crianças,

Convencidos de que para prevenir e combater esse tipo de criminalidade será útil completar a Convenção das Nações Unidas contra o Crime Organizado Transnacional com um instrumento internacional destinado a prevenir, reprimir e punir o tráfico de pessoas, especialmente mulheres e crianças,

\section{Acordam o seguinte:}

\section{Disposições Gerais}

\section{Artigo 1}

\section{Relação com a Convenção das Nações Unidas contra o Crime Organizado Transnacional}

1. O presente Protocolo completa a Convenção das Nações Unidas contra o Crime Organizado Transnacional e será interpretado em conjunto com a Convenção.

2. As disposições da Convenção aplicar-se-ão mutatis mutandis ao presente Protocolo, salvo se no mesmo se dispuser em contrário.

3. As infrações estabelecidas em conformidade com o Artigo 5 do presente Protocolo serão consideradas como infrações estabelecidas em conformidade com a Convenção.

\section{Artigo 2 \\ Objetivo}

Os objetivos do presente Protocolo são os seguintes:

a) Prevenir e combater o tráfico de pessoas, prestando uma atenção especial às mulheres e crianças;

b) Proteger e ajudar as vítimas desse tráfico, respeitando plenamente os seus direitos humanos; e 
c) Promover a cooperação entre os Estados Partes de forma a atingir esses objetivos.

\section{Artigo 3 \\ Definições}

Para efeitos do presente Protocolo:

a) A expressão "tráfico de pessoas" significa o recrutamento, o transporte, a transferência, o alojamento ou o acolhimento de pessoas, recorrendo à ameaça ou ao uso da força ou a outras formas de coação, ao rapto, à fraude, ao engano, ao abuso de autoridade ou à situação de vulnerabilidade ou à entrega ou aceitação de pagamentos ou benefícios para obter o consentimento de uma pessoa que tenha autoridade sobre outra para fins de exploração. A exploração incluirá, no mínimo, a exploração da prostituição de outrem ou outras formas de exploração sexual, o trabalho ou serviços forçados, escravatura ou práticas similares à escravatura, a servidão ou a remoção de órgãos;

b) O consentimento dado pela vítima de tráfico de pessoas tendo em vista qualquer tipo de exploração descrito na alínea a) do presente Artigo será considerado irrelevante se tiver sido utilizado qualquer um dos meios referidos na alínea a);

c) O recrutamento, o transporte, a transferência, o alojamento ou o acolhimento de uma criança para fins de exploração serão considerados "tráfico de pessoas" mesmo que não envolvam nenhum dos meio referidos da alínea a) do presente Artigo;

d) O termo "criança" significa qualquer pessoa com idade inferior a dezoito anos.

\section{Artigo 4 \\ Âmbito de aplicação}

O presente Protocolo aplicar-se-á, salvo disposição em contrário, à prevenção, investigação e repressão das infrações estabelecidas em conformidade com 0 Artigo 5 do presente Protocolo, quando essas infrações forem de natureza transnacional e envolverem grupo criminoso organizado, bem como à proteção das vítimas dessas infrações.

\section{Artigo 5 \\ Criminalização}

1. Cada Estado Parte adotará as medidas legislativas e outras que considere necessárias de forma a estabelecer como infrações penais os atos descritos no Artigo 3 do presente Protocolo, quando tenham sido praticados intencionalmente.

2. Cada Estado Parte adotará igualmente as medidas legislativas e outras que considere necessárias para estabelecer como infrações penais: 
a) Sem prejuízo dos conceitos fundamentais do seu sistema jurídico, a tentativa de cometer uma infração estabelecida em conformidade com o parágrafo 1 do presente Artigo;

b) A participação como cúmplice numa infração estabelecida em conformidade com o parágrafo 1 do presente Artigo; e

c) Organizar a prática de uma infração estabelecida em conformidade com o parágrafo 1 do presente Artigo ou dar instruções a outras pessoas para que a pratiquem

\section{Proteção de vítimas de tráfico de pessoas}

\section{Artigo 6}

\section{Assistência e proteção às vítimas de tráfico de pessoas}

1. Nos casos em que se considere apropriado e na medida em que seja permitido pelo seu direito interno, cada Estado parte protegerá a privacidade e a identidade das vítimas de tráfico de pessoas, incluindo, entre outras (ou inter alia), a confidencialidade dos procedimentos judiciais relativos a esse tráfico.

2. Cada Estado Parte assegurará que o seu sistema jurídico ou administrativo contenha medidas que forneçam às vítimas de tráfico de pessoas, quando necessário:

a) Informação sobre procedimentos judiciais e administrativos aplicáveis;

b) Assistência para permitir que as suas opiniões e preocupações sejam apresentadas e tomadas em conta em fases adequadas do processo penal instaurado contra os autores das infrações, sem prejuízo dos direitos da defesa.

3. Cada Estado Parte terá em consideração a aplicação de medidas que permitam a recuperação física, psicológica e social das vítimas de tráfico de pessoas, incluindo, se for caso disso, em cooperação com organizações não-governamentais, outras organizações competentes e outros elementos de sociedade civil e, em especial, o fornecimento de:

a) Alojamento adequado;

b) Aconselhamento e informação, especialmente quanto aos direitos que a lei lhes reconhece, numa língua que compreendam;

c) Assistência médica, psicológica e material; e

d) Oportunidade de emprego, educação e formação.

4. Cada Estado Parte terá em conta, ao aplicar as disposições do presente Artigo, a idade, o sexo e as necessidades específicas das 
vítimas de tráfico de pessoas, designadamente as necessidades específicas das crianças, incluindo o alojamento, a educação e cuidados adequados.

5. Cada Estado Parte envidará esforços para garantir a segurança física das vítimas de tráfico de pessoas enquanto estas se encontrarem no seu território.

6. Cada Estado Parte assegurará que o seu sistema jurídico contenha medidas que ofereçam às vítimas de tráfico de pessoas a possibilidade de obterem indenização pelos danos sofridos.

\section{Artigo 7}

\section{Estatuto das vítimas de tráfico de pessoas nos Estados de acolhimento}

1. Além de adotar as medidas em conformidade com o Artigo 6 do presente Protocolo, cada Estado Parte considerará a possibilidade de adotar medidas legislativas ou outras medidas adequadas que permitam às vítimas de tráfico de pessoas permanecerem no seu território a título temporário ou permanente, se for o caso disso.

2. Ao executar o disposto no parágrafo 1 do presente Artigo, cada Estado Parte terá devidamente em conta fatores humanitários e pessoais.

\section{Artigo 8 \\ Repatriamento das vítimas de tráfico de pessoas}

1. O Estado Parte do qual a vítima de tráfico de pessoas é nacional ou no qual a pessoa tinha direito de residência permanente, no momento de entrada no território do Estado do Estado Parte de acolhimento, facilitará e aceitará, sem demora indevida ou injustificada, o regresso dessa pessoa, tendo devidamente em conta a segurança da mesma.

2. Quando um Estado Parte retornar uma vítima de tráfico de pessoas a um Estado Parte do qual essa pessoa seja nacional ou no qual tinha direito de residência permanente no momento de entrada no território do Estado Parte de acolhimento, esse regresso levará devidamente em conta a segurança da pessoa bem como a situação de qualquer processo judicial relacionado ao fato de tal pessoa ser mais uma vítima de tráfico, preferencialmente de forma voluntária.

4. De forma a facilitar o regresso de uma vítima de tráfico de pessoas que não possua os documentos devidos, o Estado Parte do qual essa pessoa é nacional ou no qual tinha direito de residência permanente no momento de entrada no território do Estado Parte de acolhimento aceitará emitir, a pedido do Estado Parte de acolhimento, os documentos de viagem ou 
outro tipo de autorização necessária que permita que permita à pessoa viajar e ser readmitida no seu território.

5. O presente Artigo não prejudica os direitos reconhecidos às vítimas de tráfico de pessoas por força de qualquer disposição do direito interno do Estado Parte de acolhimento.

6. O presente Artigo não prejudica qualquer acordo ou compromisso bilateral ou

multilateral aplicável que regule, no todo ou em parte, o regresso de vítimas de tráfico de pessoas.

\section{Prevenção, cooperação e outras medidas}

\section{Artigo 9}

\section{Prevenção do tráfico de pessoas}

1. Os Estados estabelecerão políticas abrangentes, programas e outras medidas para:

a) Prevenir e combater o tráfico de pessoas; e

b) Proteger as vítimas de tráfico de pessoas, especialmente as mulheres e crianças, de nova vitimização.

2. Os Estados Partes envidarão esforços para tomarem medidas tais como pesquisas, campanhas de informação e de difusão através de órgãos de comunicação, bem como iniciativas sociais e econômicas de forma a prevenir e combater o tráfico de pessoas.

3. As políticas, programas e outras medidas estabelecidas em conformidade com o presente Artigo incluirão, se necessário, a cooperação com organizações não-governamentais, outras organizações relevantes e outros elementos da sociedade civil.

4. Os Estados Partes tomarão ou reforçarão as medidas, inclusive mediante a cooperação bilateral ou multilateral, para reduzir os fatores como a pobreza, o subdesenvolvimento e a desigualdade de oportunidades que tornam as pessoas, especialmente as mulheres e crianças, vulneráveis ao tráfico.

5. Os Estados Partes adotarão ou reforçarão as medidas legislativas ou outras, tais como medidas educacionais, sociais ou culturais, inclusive mediante a cooperação bilateral ou multilateral, a fim de desencorajar a procura que fomenta todo o tipo de exploração de pessoas, especialmente de mulheres e crianças, conducentes ao tráfico. 


\section{Artigo 10 \\ Intercâmbio de informações e formação}

1. As autoridades competentes para a aplicação da lei, os serviços de imigração ou outros serviços competentes dos Estados Partes, cooperarão entre si, na medida do possível, mediante troca de informações em conformidade com o respectivo direito interno, com vistas a determinar:

a) Se as pessoas que atravessam ou tentam atravessar uma fronteira internacional com documentos de viagem pertencentes a terceiros ou sem documentos de viagem são autores ou vítimas de tráfico de pessoas;

b) Os tipos de documentos de viagem que as pessoas têm utilizado ou tentado utilizar para atravessar uma fronteira internacional com o objetivo de tráfico de pessoas; e

c) Os meios e métodos utilizados por grupos criminosos organizados com o objetivo de tráfico de pessoas, incluindo o recrutamento e o transporte de vítimas, os itinerários e ligações entre as pessoas e os grupos envolvidos no referido tráfico, bem como as medidas adequadas à sua detecção.

2. Os Estados Partes assegurarão ou reforçarão a formação dos agentes dos serviços competentes para a aplicação da lei, dos serviços de imigração ou de outros serviços competentes na prevenção do tráfico de pessoas. A formação deve incidir sobre os métodos utilizados na prevenção do referido tráfico, na ação penal contra os traficantes e na proteção das vítimas, inclusive protegendo-as dos traficantes. A formação também deverá ter em conta a necessidade de considerar os direitos humanos e os problemas específicos das mulheres e das crianças bem como encorajar a cooperação com organizações nãogovernamentais, outras organizações relevantes e outros elementos da sociedade civil.

3. Um Estado Parte que receba informações respeitará qualquer pedido do Estado Parte que transmitiu essas informações, no sentido de restringir sua utilização.

\section{Artigo 11 \\ Medidas nas fronteiras}

1. Sem prejuízo dos compromissos internacionais relativos à livre circulação de pessoas, os Estados Partes reforçarão, na medida do possível, os controles fronteiriços necessários para prevenir e detectar o tráfico de pessoas.

2. Cada Estado Parte adotará medidas legislativas ou outras medidas apropriadas para prevenir, na medida do possível, a utilização de meios de transporte explorados por transportadores comerciais na prática de infrações estabelecidas em conformidade com o Artigo 5 do presente Protocolo. 
3. Quando se considere apropriado, e sem prejuízo das convenções internacionais aplicáveis, tais medidas incluirão o estabelecimento da obrigação para os transportadores comerciais, incluindo qualquer empresa de transporte, de certificar-se de que todos os passageiros sejam portadores dos documentos de viagens exigidos para entrada no Estão de acolhimento.

4. Cada Estado Parte tomará as medidas necessárias, em conformidade com o seu direito interno, para aplicar sanções em caso de descumprimento da obrigação constante do parágrafo 3 do presente Artigo.

5. Cada Estado Parte considerará a possibilidade de tomar medidas que permitam, em conformidade com o Direito interno, recusar a entrada ou anular os vistos de pessoas envolvidas na prática de infrações estabelecidas em conformidade com o presente Protocolo.

6. Sem prejuízo do disposto no Artigo 27 da Convenço, os Estados Partes procurarão intensificar a cooperação entre os serviços de controle de fronteiras, mediante, entre outros, o estabelecimento e a manutenção de canais de comunicação diretos.

\section{Artigo 12}

\section{Segurança e controle dos documentos}

Cada Estado Parte adotará as medidas necessárias, de acordo com os meios disponíveis para:

a) Assegurar a qualidade dos documentos de viagem ou de identidade que emitir, para que não sejam indevidamente utilizados nem facilmente falsificados ou modificados, reproduzidos ou emitidos de forma ilícita; e

b) Assegurar a integridade e a segurança dos documentos de viagem ou de identidade por si ou em seu nome emitidos e impedir a sua criação, emissão ou utilização ilícitas.

\section{Artigo 13}

\section{Legitimidade e validade dos documentos}

A pedido de outro Estado Parte, um Estado Parte verificará, em conformidade com o seu direito interno e dentro de um prazo razoável, a legitimidade e validade dos documentos de viagem ou de identidade emitidos ou supostamente emitidos em seu nome e de que tenha suspeita terem sido utilizados para o tráfico de pessoas. 


\section{Artigo 14}

\section{Disposições finais}

\section{Cláusula de salvaguarda}

1. Nenhuma disposição do presente Protocolo prejudicará os direitos, obrigações e responsabilidades dos Estados e das pessoas que por força do direito internacional, incluindo o direito internacional humanitário e o direito internacional relativo aos direitos humanos e, especificamente, na medida em que sejam aplicáveis, a Convenção de 1951 e o Protocolo de 1967 relativos ao Estatuto dos Refugiados e ao princípio do nonrefoulement neles enunciados.

2. As medidas constantes do presente Protocolo serão interpretadas e aplicadas de forma a que as pessoas que foram vítimas de tráfico não sejam discriminadas. A interpretação e aplicação das referidas medidas estarão em conformidade com os princípios de não discriminação internacionalmente reconhecidos.

\section{Artigo 15 \\ Solução de controvérsias}

1. Os Estados Partes envidarão esforços para resolver as controvérsias relativas à interpretação ou aplicação do presente Protocolo por negociação direta.

2. As controvérsias entre dois ou mais Estados partes com respeito à aplicação ou à interpretação do presente Protocolo que não possam ser resolvidas por negociação, dentro de um prazo razoável, serão submetidas, a pedido de um desses Estados Partes, a arbitragem. Se, no prazo de seis meses após a data do pedido de arbitragem, esses Estados partes não chegarem a um acordo sobre a organização da arbitragem, qualquer desses Estados Partes poderá submeter o diferendo ao Tribunal Internacional de justiça mediante requerimento, em conformidade com o Estatuto do Tribunal.

3. Cada Estado Parte pode, no momento da assinatura, da ratificação, da aceitação ou da aprovação do presente Protocolo ou da adesão ao mesmo, declarar que não se considera vinculado ao parágrafo 2 do presente Artigo. Os demais Estados partes não ficarão vinculados ao parágrafo 2 do presente Artigo em relação a qualquer outro Estado parte que tenha feito essa reserva.

4. Qualquer Estado Parte que tenha feito uma reserva em conformidade com o parágrafo 3 do presente Artigo pode, a qualquer momento, retirar essa reserva através de notificação ao Secretário-Geral das Nações Unidas.

\section{Artigo 16}

Assinatura, ratificação, aceitação, aprovação e adesão 
1. O presente Protocolo será aberto à assinatura de todos os Estados de 12 a 15 de Dezembro de 2000 em Palermo, Itália, e, em seguida, na sede da Organização das Nações Unidas em Nova lorque até 12 de Dezembro de 2002.

2. O presente Protocolo será igualmente aberto à assinatura de organizações regionais de integração econômica na condição de que pelo menos um Estado membro dessa organização tenha assinado o presente Protocolo em conformidade com o parágrafo 1 do presente Artigo.

3. O presente Protocolo está sujeito a ratificação, aceitação ou aprovação. Os instrumentos de ratificação, de aceitação ou de aprovação serão depositados junto ao Secretário-Geral da Organização das Nações Unidas. Uma organização regional de integração-econômica pode depositar o seu instrumento de ratificação, de aceitação ou de aprovação se pelo menos um dos seus Estados membros o tiver feito. Nesse instrumento de ratificação, aceitação e de aprovação essa organização declarará o âmbito da sua competência relativamente às matérias reguladas pelo presente Protocolo. Informará igualmente o depositário de qualquer modificação relevante do âmbito de sua competência.

\section{Artigo 17 Entrada em vigor}

1. O presente Protocolo entrará em vigor no nonagésimo dia seguinte à data do depósito do quadragésimo instrumento de ratificação, de aceitação, de aprovação ou de adesão mas não antes da entrada em vigor da Convenção. Para efeitos do presente número, nenhum instrumento depositado por uma organização regional de integração econômica será somado aos instrumentos depositados por Estados membros dessa organização.

2. Para cada Estado ou organização regional de integração econômica que ratifique, aceite, aprove ou adira ao presente Protocolo após o depósito do quadragésimo instrumento pertinente, o presente Protocolo entrará em vigor no trigésimo dia seguinte à data de depósito desse instrumento por parte do Estado ou organização ou na data de entrada em vigor do presente Protocolo, em conformidade com o parágrafo 1 do presente Artigo, se esta for posterior.

\section{Artigo 18 \\ Emendas}

1. Cinco anos após a entrada em vigor do presente Protocolo, um Estado Parte no Protocolo pode propor emenda e depositar o texto junto do Secretário-Geral das Nações Unidas, que em seguida comunicará a proposta de emenda aos Estados partes e à Conferência das partes na Convenção para analisar a proposta e tomar uma decisão. Os Estados Partes no presente Protocolo reunidos na Conferência das Partes farão todos os esforços para chegar a um consenso forem esgotados e não se chegar a um acordo, será necessário, em último caso, 
para que a alteração seja aprovada, uma maioria de dois terços dos Estados partes no presente Protocolo, que estejam presentes e expressem o seu voto na Conferência das partes.

2. As organizações regionais de integração econômica, em matéria da sua competência, exercerão o seu direito de voto nos termos do presente Artigo com um número de votos igual ao número dos seus Estados membros que sejam partes no presente Protocolo. Essas organizações não exercerão seu direito de voto se seus Estados membros exercerem o seu e vice-versa.

3. Uma emenda adotada em conformidade com o parágrafo 1 do presente Artigo estará sujeita a ratificação, aceitação ou aprovação dos Estados Partes.

4. Uma emenda adotada em conformidade com o parágrafo 1 do presente Protocolo entrará em vigor para um Estado Parte noventa dias após a data do depósito do instrumento de ratificação, de aceitação ou de aprovação da referida emenda junto ao Secretário-Geral das Nações Unidas.

5. A entrada em vigor de uma emenda vincula as Partes que manifestaram o seu

consentimento em obrigar-se por essa alteração. Os outros Estados partes permanecerão vinculados pelas disposições do presente Protocolo, bem como por qualquer alteração anterior que tenham ratificado, aceito ou aprovado.

\section{Artigo 19 \\ Denúncia}

1. Um Estado Parte pode denunciar o presente Protocolo mediante notificação por escrito dirigida ao Secretário-Geral das Nações Unidas. A denúncia tornar-se-á efetiva um ano após a data de recepção da notificação pelo Secretário-Geral.

2. Uma organização regional de integração econômica deixará de ser Parte no presente Protocolo quando todos os seus Estados membros o tiverem denunciado.

\section{Artigo 20 \\ Depositário e idiomas}

1. O Secretário-Geral das Nações Unidas é o depositário do presente Protocolo.

2. O original do presente Protocolo, cujos textos em árabe, chinês, espanhol, francês, inglês e russo são igualmente autênticos, será depositado junto ao Secretário-Geral das Nações Unidas. 


\section{7 \\ Anexo 7 - Convenção do Conselho da Europa Relativa à Luta contra o Tráfico de Seres Humanos}

Os Estados membros do Conselho da Europa e os restantes signatários da presente Convenção:

Considerando que o objectivo do Conselho da Europa é o de realizar uma união mais estreita entre os seus membros;

Considerando que o tráfico de seres humanos constitui uma violação dos direitos humanos e uma ofensa à dignidade e à integridade do ser humano;

Considerando que o tráfico de seres humanos pode conduzir a uma situação de escravidão para as vítimas;

Considerando que o respeito dos direitos das vítimas e a sua protecção, bem como a luta contra o tráfico de seres humanos, devem constituir objectivos primordiais;

Considerando que qualquer acção ou iniciativa no domínio da luta contra o tráfico de seres humanos deve ser não discriminatória e deve ter em consideração tanto a igualdade entre as mulheres e os homens como uma abordagem baseada nos direitos da criança;

Relembrando as declarações dos Ministros dos Negócios Estrangeiros dos Estados membros por ocasião das 112. a (14 e 15 de Maio de 2003) e 114. ${ }^{\text {a }}$ (12 e 13 de Maio de 2004) Sessões do Comité de Ministros, apelando a uma

acção reforçada do Conselho da Europa no domínio do tráfico de seres humanos;

Tendo presente a Convenção para a Protecção dos Direitos do Homem e das Liberdades Fundamentais (1950) e os seus protocolos;

Tendo presentes as seguintes Recomendações do Comité de Ministros aos Estados membros do Conselho da Europa:

Recomendação R (91) 11 sobre a exploração sexual, a pornografia, a prostituição, bem como sobre o tráfico de crianças e de jovens; Recomendação R (97) 13 sobre a intimidação das testemunhas e os direitos de defesa;

Recomendação $R$ (2000) 11 sobre a luta contra o tráfico de seres humanos com o fim de exploração sexual;

Recomendação Rec (2001) 16 sobre a protecção das crianças contra a exploração sexual;

Recomendação Rec. (2002) 5 sobre a protecção das mulheres contra a violência; 
Tendo presentes as seguintes Recomendações da Assembleia Parlamentar do Conselho da Europa:

Recomendação n. 1325 (1997) relativa ao tráfico das mulheres e à prostituição forçada nos Estados membros do Conselho da Europa;

Recomendação n. -1450 (2000) sobre a violência contra as mulheres na Europa; Recomendação n.ํ 1545 (2002) relativa a campanhas de luta contra o tráfico de mulheres;

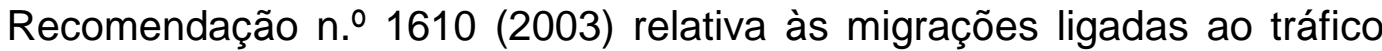
de mulheres e à prostituição;

Recomendação n. 1611 (2003) relativa ao tráfico de órgãos na Europa;

Recomendação $n .^{\circ} 1663$ (2004) sobre a escravatura doméstica: servidão, pessoas colocadas au pair e esposas obtidas por correspondência;

Tendo presentes a Decisão Quadro do Conselho da Europa, de 19 de Julho de 2002, relativa à luta contra o tráfico de seres humanos, bem como a Decisão Quadro do Conselho da União Europeia, de 15 de Março de 2001,

relativa ao estatuto da vítima em processo penal, e a Directiva do Conselho da União Europeia, de 29 de Abril de 2004, relativa ao título de residência concedido aos nacionais de países terceiros que sejam vítimas de tráfico de seres humanos ou objecto de uma acção de auxílio à imigração ilegal e que cooperem com as autoridades competentes;

Tendo em devida consideração a Convenção das Nações Unidas contra a Criminalidade Organizada Transnacional e respectivo Protocolo Adicional Que Visa Prevenir, Suprimir e Sancionar o Tráfico de Seres Humanos, particularmente as Mulheres e as Crianças, com vista a reforçar a protecção assegurada por estes instrumentos e a desenvolver as normas neles enunciadas;

Tendo em devida consideração outros instrumentos jurídicos internacionais pertinentes no domínio da luta contra o tráfico de seres humanos;

Tendo em consideração a necessidade de elaborar um instrumento jurídico internacional global centrado nos direitos humanos das vítimas de tráfico e que crie um mecanismo de acompanhamento específico; acordaram no seguinte:

\section{CAPÍTULO I \\ Finalidade, âmbito de aplicação, princípio da não discriminação e definições Artigo 1.ำ \\ Finalidade da Convenção}

1 - A presente Convenção tem por finalidade:

a) Prevenir e lutar contra o tráfico de seres humanos, garantindo a igualdade entre mulheres e homens;

b) Proteger os direitos humanos das vítimas de tráfico, estabelecer um quadro completo de protecção e de assistência às vítimas e às 
testemunhas garantindo a igualdade entre mulheres e homens, bem como assegurar investigações e procedimentos eficazes;

c) Promover a cooperação internacional no domínio da luta contra o tráfico de seres humanos.

2 - A fim de garantir uma aplicação eficaz das suas disposições pelas Partes, a presente Convenção cria um mecanismo de acompanhamento específico.

\section{Artigo 2.. \\ Âmbito de aplicação}

A presente Convenção será aplicável a todas as formas de tráfico de seres humanos, de âmbito nacional ou internacional, independentemente da sua ligação ou não ligação à criminalidade organizada.

Artigo 3.음

\section{Princípio da não discriminação}

A aplicação da presente Convenção pelas Partes, em particular das medidas que visam proteger e promover os direitos das vítimas, deverá ser assegurada sem qualquer discriminação com base no sexo, na raça, na cor, na língua, na religião, nas opiniões políticas ou outras, na origem nacional ou social, na pertença a uma minoria nacional, na riqueza, no nascimento ou em qualquer outra situação.

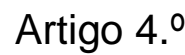

\section{Definições}

Para efeitos da presente Convenção:

a) «Tráfico de seres humanos» designa o recrutamento, o transporte, a transferência, o alojamento ou o acolhimento de pessoas, recorrendo à ameaça ou ao uso da força ou a outras formas de coacção, ao rapto, à fraude, ao engano, ao abuso de autoridade ou de uma situação de vulnerabilidade ou à entrega ou aceitação de pagamentos ou benefícios para obter o consentimento de uma pessoa com autoridade sobre outra, para fins de exploração. A exploração deverá incluir, pelo menos, a exploração da prostituição de outrem ou outras formas de exploração sexual, o trabalho ou serviços forçados, a escravatura ou práticas similares à escravatura, a servidão ou a extracção de órgãos;

b) O consentimento dado pela vítima de «tráfico de seres humanos» à exploração referida na alínea a) do presente artigo será considerado irrelevante se tiver sido utilizado qualquer um dos meios indicados na alínea a) do presente artigo;

O recrutamento, o transporte, a transferência, o alojamento ou o acolhimento de uma criança para fins de exploração deverão ser considerados «tráfico de seres humanos» mesmo que não envolvam nenhum dos meios referidos na alínea a) do presente artigo; 
d) «Criança» designa qualquer pessoa com idade inferior a 18 anos;

e) "Vítima» designa qualquer pessoa física sujeita a tráfico de seres humanos conforme definido no presente artigo.

\section{CAPÍTULO II \\ Prevenção, cooperação e outras medidas \\ Artigo 5. \\ Prevenção do tráfico de seres humanos}

1 - Cada uma das Partes tomará medidas que visem estabelecer ou reforçar a coordenação, a nível nacional, entre as diferentes entidades responsáveis pela prevenção e pela luta contra o tráfico de seres humanos.

2 - Cada uma das Partes criará e ou apoiará políticas e programas eficazes a fim de prevenir o tráfico de seres humanos através de meios como: pesquisas; campanhas de informação, sensibilização e educação; iniciativas sociais e económicas e programas de formação, particularmente dirigidos a pessoas vulneráveis ao tráfico e aos profissionais envolvidos na luta contra o tráfico de seres humanos.

3 - Cada uma das Partes promoverá uma abordagem baseada nos direitos humanos e na igualdade entre mulheres e homens, bem como uma abordagem que respeite as crianças, no desenvolvimento, na implementação e na avaliação do conjunto de políticas e programas referidos no ก.. 2 .

4 - Cada uma das Partes tomará as medidas adequadas, que se mostrem necessárias, para garantir que as migrações serão feitas de forma legal, em particular mediante a difusão de informações exactas pelos respectivos serviços sobre as condições de entrada e permanência legais no seu território.

5 - Cada uma das Partes tomará medidas específicas por forma a reduzir a vulnerabilidade das crianças relativamente ao tráfico, designadamente criando, para elas, um ambiente protector.

6 - As medidas previstas em conformidade com o presente artigo abrangerão, se for caso disso, as organizações não governamentais, outras organizações competentes e outros sectores da sociedade civil envolvidos na prevenção do tráfico de seres humanos, na protecção ou na assistência

às vítimas.

\section{Artigo 6.. \\ Medidas para desencorajar a procura}

A fim de desencorajar a procura que favorece todas as formas de exploração das pessoas, em particular de mulheres e crianças, conducente ao tráfico, cada uma das Partes adoptará ou reforçará 
medidas legislativas, administrativas, educativas, sociais, culturais ou outras, incluindo:

a) Pesquisas sobre as melhores práticas, métodos e estratégias;

b) Medidas visando a consciencialização da responsabilidade e do importante papel dos meios de comunicação e da sociedade civil na identificação da procura como uma das causas profundas do tráfico de seres humanos;

c) Campanhas de informação direccionadas, envolvendo, se apropriado, as autoridades públicas e os decisores políticos, entre outros;

d) Medidas preventivas que incluam programas educativos destinados às raparigas e aos rapazes em fase de escolaridade, que sublinhem o carácter inaceitável da discriminação com base no sexo e as suas consequências

nefastas, a importância da igualdade entre mulheres e homens, bem como a dignidade e a integridade de cada ser humano.

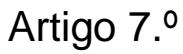 \\ Medidas nas fronteiras}

1 - Sem prejuízo dos compromissos internacionais relativos à livre circulação de pessoas, as Partes reforçarão, na medida do possível, os controlos fronteiriços necessários para prevenir e detectar o tráfico de seres humanos.

2 - Cada uma das Partes adoptará as medidas legislativas ou outras apropriadas para prevenir, na medida do possível, a utilização de meios de transporte explorados por transportadores comerciais para a prática de infracções penais previstas em conformidade com a presente Convenção.

3 - Se for caso disso, e sem prejuízo das convenções internacionais aplicáveis, tais medidas deverão prever, em particular, a obrigação de os transportadores comerciais, incluindo qualquer empresa de transportes, proprietário ou operador de qualquer meio de transporte, verificarem se todos os passageiros são portadores dos documentos de viagem exigidos para a entrada no Estado de acolhimento.

4 - Cada uma das Partes tomará as medidas necessárias, em conformidade com o seu direito interno, para prever sanções em caso de incumprimento da obrigação referida no n. $\stackrel{0}{3}$ do presente artigo.

5 - Cada uma das Partes adoptará as medidas legislativas ou outras necessárias que lhe permitam, em conformidade com o seu direito interno, recusar a entrada ou revogar os vistos de pessoas envolvidas na prática das infracções previstas em conformidade com a presente Convenção.

6 - As Partes intensificarão a cooperação entre os seus serviços de controlo de fronteiras, em particular criando e mantendo canais de comunicação directos. 


\title{
Artigo 8.. \\ Segurança e controlo dos documentos
}

Cada uma das Partes tomará as medidas necessárias para:

a) Assegurar que a qualidade dos documentos de viagem ou de identidade por si emitidos dificulte a sua utilização indevida ou a sua falsificação ou alteração, bem como a sua reprodução ou emissão ilícitas; e

b) Assegurar a integridade e a segurança dos documentos de viagem ou de identidade emitidos por si ou em seu nome, bem como para impedir que tais documentos sejam produzidos $\mathrm{e}$ emitidos de forma ilícita.

Artigo 9.음

\section{Legitimidade e validade dos documentos}

A pedido de qualquer uma das outras Partes, uma Parte verificará, em conformidade com o seu direito interno e num prazo razoável, a legitimidade e a validade dos documentos de viagem ou de identidade emitidos ou supostamente emitidos em seu nome de que se suspeite terem sido utilizados para o tráfico de seres humanos.

\author{
CAPÍTULO III \\ Medidas que visam proteger e promover os direitos \\ das vítimas, garantindo \\ a igualdade entre mulheres e homens
}

\section{Artigo 10.ำ \\ Identificação das vítimas}

1 - Cada uma das Partes assegurar -se -á de que as suas autoridades competentes dispõem de pessoas formadas e qualificadas no domínio da prevenção e da luta contra o tráfico de seres humanos, bem como da identificação das vítimas, em particular das crianças, e do apoio a estas últimas, assegurando -se ainda que as diversas autoridades envolvidas colaboram entre si e com as organizações com funções de apoio, de modo a permitir a identificação das vítimas num processo que tenha em consideração a situação específica das mulheres e das crianças vítimas e, nos casos apropriados, a emissão de autorizações de permanência de acordo com as condições previstas no artigo 14.ำ da presente Convenção.

2 - Cada uma das Partes adoptará as medidas legislativas ou outras que se mostrem necessárias para identificar as vítimas, se for caso disso, em colaboração com outras Partes e com as organizações com funções de apoio. Cada uma das Partes garantirá que, caso as autoridades competentes entendam haver motivos razoáveis para crer que uma pessoa foi vítima de tráfico de seres humanos, tal pessoa não será expulsa do seu território até à conclusão do processo de identificação 
enquanto vítima da infracção prevista no artigo 18.9 da presente Convenção, pelas autoridades competentes, e que beneficiará da assistência prevista nos $\mathrm{n} . .01$ e 2 do artigo $12 .$.

3 - Em caso de incerteza quanto à idade da vítima e desde que haja razões para crer que se trata de uma criança, presumir -se -á que se trata de uma criança e ser -lhe -ão concedidas medidas de protecção específicas até que a sua idade seja determinada.

4 - Logo que uma criança não acompanhada seja identificada como vítima, cada uma das Partes:

a) Providenciará pela sua representação através de um tutor legal, de uma organização ou de uma autoridade encarregada de agir em conformidade com os seus superiores interesses;

b) Tomará as medidas que considere necessárias para determinar a sua idade e a sua nacionalidade;

c) Desenvolverá todos os esforços no sentido de localizar a família da criança, desde que tal seja do seu superior interesse.

\section{Artigo 11. \\ Protecção da vida privada}

1 - Cada uma das Partes protegerá a vida privada e a identidade das vítimas. Os dados de natureza pessoal que lhes digam respeito serão registados e utilizados nas condições previstas pela Convenção para a Protecção das Pessoas relativamente ao Tratamento Automatizado de Dados de Carácter Pessoal (STE n.ำ108).

2 - Cada uma das Partes tomará medidas que, em particular, garantam que a identidade, ou os elementos que permitam a identificação, de uma criança vítima de tráfico não serão tornados públicos pelos meios de comunicação ou outros, excepto se, em circunstâncias excepcionais, tal publicidade facilitar a localização de membros da família da criança ou garantir, de outro modo, o seu bem -estar e a sua protecção.

3 - Cada uma das Partes considerará a adopção, em conformidade com o artigo 10. da Convenção para a Protecção dos Direitos do Homem e das Liberdades Fundamentais, de medidas que visem encorajar os meios de

comunicação a proteger a vida privada e a identidade das vítimas através da auto -regulação ou de medidas de regulação ou co -regulação.

Artigo 12.ำ

\section{Assistência às vítimas}

1 - Cada uma das Partes tomará as medidas legislativas ou outras necessárias para auxiliar as vítimas na sua recuperação física, psicológica e social. Tal assistência incluirá, pelo menos: 
a) Condições de vida susceptíveis de garantir a sua subsistência através de acomodação adequada e segura, apoio psicológico e material;

b) Acesso a cuidados médicos de urgência;

c) Ajuda em matéria de tradução e interpretação, se necessário;

d) Aconselhamento e prestação de informações, nomeadamente sobre os direitos que a lei lhes reconhece e sobre os serviços postos à sua disposição, numa língua que compreendam;

e) Assistência para que os seus direitos e interesses sejam assegurados e tidos em conta em todas as fases do procedimento penal instaurado contra os autores das infracções;

f) Acesso das crianças à educação.

2 - Cada uma das Partes tomará em devida consideração a necessidade de segurança e protecção das vítimas.

3 - Cada uma das Partes fornecerá, ainda, a assistência médica necessária ou qualquer outro tipo de assistência às vítimas que residam legalmente no seu território, que não disponham dos recursos adequados e dela necessitem.

4 - Cada uma das Partes estabelecerá as regras segundo as quais as vítimas legalmente residentes no seu território poderão aceder ao mercado de trabalho, à formação profissional e ao ensino.

5 - Cada uma das Partes tomará medidas, conforme se mostre apropriado e nas condições previstas pelo seu direito interno, para cooperar com as organizações não governamentais, com outras organizações competentes ou outros sectores da sociedade civil envolvidos na assistência às vítimas.

6 - Cada uma das Partes adoptará as medidas legislativas ou outras necessárias para garantir que a assistência a uma vítima não fique condicionada à sua disponibilidade para testemunhar.

7 - Para efeitos de aplicação das disposições previstas no presente artigo, cada uma das Partes garantirá que os serviços serão prestados numa base consensual e esclarecida, sendo dada devida consideração às necessidades específicas das pessoas em situação vulnerável e aos direitos das crianças em matéria de acomodação, educação e cuidados de saúde adequados.

\section{Artigo 13.}

\section{Período de restabelecimento e reflexão}

1 - Cada uma das Partes consagrará, no seu direito interno, um período de, pelo menos, 30 dias para restabelecimento e reflexão se houver motivos razoáveis para crer que determinada pessoa é uma vítima. $O$ referido período deverá ter uma duração que permita à pessoa a que 
respeita restabelecer -se e escapar à influência de traficantes, bem como tomar uma decisão esclarecida relativamente à sua cooperação com as autoridades competentes. Durante esse período, não deverá ser executada qualquer medida de expulsão que lhe respeite. Esta disposição não prejudicará quaisquer diligências por parte das autoridades competentes nas diferentes fases do processo aplicável a nível interno, em particular na fase de investigação e procedimento das infracções criminais. Durante tal período, as Partes autorizarão a permanência dessa pessoa no seu território.

2 - Durante o mesmo período, as pessoas referidas no $\mathrm{n} . .-1$ do presente artigo terão direito a usufruir das medidas previstas nos n.os 1 e 2 do artigo 12.

3 - As Partes não serão obrigadas a respeitar o referido período com fundamento em razões de ordem pública ou sempre que se afigure que a qualidade de vítima é invocada indevidamente.

\section{Artigo $14 .{ }^{\circ}$}

\section{Autorização de residência}

1 - Cada uma das Partes emitirá uma autorização de residência renovável, em nome das vítimas, sempre que se verifique um ou ambos os seguintes casos:

a) A autoridade competente considere que a permanência das vítimas se mostra necessária devido à sua situação pessoal;

b) A autoridade competente considere que a permanência das vítimas se mostra necessária para efeitos de cooperação com as autoridades competentes para a investigação ou para a instauração de procedimento criminal.

2 - A autorização de residência das crianças vítimas, se legalmente necessária, será emitida em conformidade com o seu superior interesse e, se for caso disso, renovada nas mesmas condições.

3 - A não renovação ou a retirada de uma autorização de residência ficará sujeita às condições previstas no direito interno da Parte.

4 - Se uma vítima solicitar um título de residência de outra categoria, a respectiva Parte terá em consideração o facto de a vítima ter beneficiado ou beneficiar de uma autorização de residência emitida nos termos do n.. 1.

5 - Relativamente às obrigações das Partes previstas no artigo 40. da presente Convenção, cada uma das Partes assegurar -se -á de que a emissão de uma autorização em conformidade com esta disposição não prejudicará o direito de solicitar asilo e dele beneficiar. 


\section{Artigo 15.ㅇ}

\section{Indemnização e apoio}

1 - Cada uma das Partes deverá assegurar às vítimas, desde o seu primeiro contacto com as autoridades competentes, 0 acesso a informação sobre procedimentos judiciais e administrativos aplicáveis, numa língua que compreendam.

2 - Cada uma das Partes consagrará, no seu direito interno, o direito à assistência e ao apoio jurídico gratuito para as vítimas, nas condições previstas pelo seu direito interno.

3 - Cada uma das Partes consagrará, no seu direito interno, o direito das vítimas a serem indemnizadas pelos autores das infracções.

4 - Cada uma das Partes adoptará as medidas legislativas ou outras necessárias para garantir a indemnização das vítimas, nas condições previstas no seu direito interno, mediante, por exemplo, a criação de um fundo de indemnização às vítimas ou outras medidas ou programas destinados à assistência e à integração social das vítimas, podendo ser financiados pelos valores resultantes da aplicação das medidas previstas no artigo $23 .$.

\section{Artigo 16.}

\section{Repatriamento e regresso das vítimas}

1 - A Parte de que uma vítima seja nacional ou na qual tinha o direito de residir a título permanente no momento da sua entrada no território da Parte de acolhimento facilitará e aceitará, tendo em devida consideração os direitos, a segurança e a dignidade da pessoa, o seu regresso sem atraso injustificado ou não razoável.

2 - Sempre que uma Parte reenviar uma vítima para outro Estado, tal regresso terá em devida consideração os direitos, a segurança e a dignidade da pessoa, bem como o estado de qualquer processo judicial relacionado com o seu estatuto de vítima, devendo o regresso ser preferencialmente voluntário.

3 - A pedido de uma Parte de acolhimento, a Parte requerida verificará se uma determinada pessoa é seu nacional ou tinha o direito de residir, a título permanente, no seu território aquando da sua entrada no território da Parte

de acolhimento.

4 - A fim de facilitar o regresso de uma vítima que não possua os documentos exigidos, a Parte de que tal pessoa seja nacional ou na qual tinha o direito de residir a título permanente aquando da sua entrada no território da Parte de acolhimento aceitará emitir, a pedido da Parte de 
acolhimento, os documentos de viagem ou qualquer outra autorização necessária para permitir à pessoa deslocar -se e reentrar no seu território.

5 - Cada uma das Partes tomará as medidas legislativas ou outras necessárias para implementar programas de repatriamento com a participação das instituições nacionais ou internacionais e das organizações não governamentais.

Tais programas visam evitar a revitimização. Cada uma das Partes deverá efectuar todos os esforços para facilitar a reinserção social das vítimas no Estado de regresso, incluindo a reinserção no sistema educativo e no mercado de trabalho em particular através da aquisição e do aperfeiçoamentodos conhecimentos profissionais. Relativamente às crianças, tais programas deverão incluir o gozo do direito à educação $\mathrm{e}$ medidas que visem garantir uma protecção ou um acolhimento adequados pelas famílias ou por estruturas de acolhimento apropriadas.

6 - Cada uma das Partes tomará as medidas legislativas ou outras necessárias para disponibilizar às vítimas, se necessário em colaboração com qualquer uma das Partes envolvidas, informação sobre as entidades que thes poderão prestar auxílio no país para onde regressem ou para onde

sejam repatriadas, tais como os serviços responsáveis pelo cumprimento da lei, as organizações não governamentais, as entidades jurídicas com capacidade para lhes prestarem aconselhamento e os organismos de acção social.

7 - As crianças vítimas não serão repatriadas para um Estado se, após uma avaliação sobre os riscos e a segurança, se considerar que o seu regresso não corresponde ao seu superior interesse.

\section{Artigo 17. \\ Igualdade entre mulheres e homens}

Ao aplicar as medidas previstas no presente capítulo, cada uma das Partes procurará promover a igualdade entre mulheres e homens, tomando-a em consideração para fins de desenvolvimento, implementação e avaliação de tais medidas.

\section{CAPÍTULO IV \\ Direito penal substantivo \\ Artigo 18. \\ Criminalização do tráfico de seres humanos}

Cada uma das Partes procurará adoptar as medidas legislativas e outras necessárias para qualificar como infracções penais os actos referidos no artigo $4 . .$. da presente Convenção, quando praticados intencionalmente. 
Artigo 19.

\section{Criminalização da utilização dos serviços de uma vítima}

Cada uma das Partes procurará adoptar as medidas legislativas e outras necessárias para qualificar como infracção penal, nos termos do seu direito interno, a utilização dos serviços que constituem objecto da exploração referida na alínea a) do artigo $4 .$. a da presente Convenção, com conhecimento de que a pessoa em causa é vítima de tráfico de seres humanos.

\section{Artigo 20.}

\section{Criminalização dos actos relativos aos documentos de viagem ou de identificação}

Cada uma das Partes adoptará as medidas legislativas e outras necessárias para qualificar como infracções penais os seguintes actos, quando cometidos intencionalmente e para permitir o tráfico de seres humanos:

a) Fabricar um documento de viagem ou de identidade falso; Obter ou fornecer tal documento;

b) Reter, subtrair, alterar, danificar ou destruir um documento de viagem ou de identidade de outra pessoa.

Artigo 21.ำ

\section{Auxílio, instigação e tentativa}

1 - Cada uma das Partes adoptará as medidas legislativas e outras que se revelem necessárias para que sejam abrangidas pela norma incriminadora qualquer forma de auxílio ou instigação, quando intencionais, com vista à

prática de qualquer uma das infracções previstas nos artigos $18 . .^{\circ}$ e 20. ․․ da presente Convenção.

2 - Cada uma das Partes adoptará as medidas legislativas e outras que se revelem necessárias para que seja abrangida pela norma incriminadora a tentativa, desde que intencional, para praticar qualquer uma das infracções penais previstas no artigo 18. e da alínea a) do artigo 20. da presente Convenção.

\section{Artigo 22..}

\section{Responsabilidade das pessoas colectivas}

Cada uma das Partes adoptará as medidas legislativas e outras que se revelem necessárias para garantir que as pessoas colectivas possam ser consideradas responsáveis pelas infracções previstas nos termos da presente Convenção cometidas em seu benefício por qualquer pessoa singular, agindo individualmente ou como membro de um órgão da pessoa colectiva, que nela ocupe uma posição dominante baseada em:

a) Poderes de representação da pessoa colectiva;

b) Autoridade para tomar decisões em nome da pessoa colectiva;

c) Autoridade para exercer controlo no seio da pessoa colectiva. 
2 - Para além dos casos previstos no $n . \circ 1$, cada uma das Partes adoptará as medidas necessárias para garantir que as pessoas colectivas possam ser consideradas responsáveis sempre que a falta de vigilância ou de controlo

por parte de uma pessoa referida no $n .{ }^{\circ} 1$ tenha tornado possível a prática de uma infracção prevista nos termos da presente Convenção, em benefício dessa pessoa colectiva, por uma pessoa singular sujeita à sua autoridade.

3 - De acordo com os princípios jurídicos da Parte, a responsabilidade de uma pessoa colectiva poderá ser de natureza penal, civil ou administrativa.

4 - Tal responsabilidade será estabelecida sem prejuízo da responsabilidade penal das pessoas singulares que tenham cometido a infracção.

\section{Artigo 23..$^{-}$}

\section{Sanções e medidas}

1 - Cada uma das Partes adoptará as medidas que se revelem necessárias para garantir que as infracções previstas nos artigos $18 .{ }^{\circ}$ a 21. sejam punidas com sanções eficazes, proporcionais e dissuasoras. Tais sanções incluirão, relativamente às infracções previstas no artigo 18. ${ }^{\circ}$ cometidas por pessoas singulares, sanções privativas de liberdade que possam dar lugar a extradição.

2 - Cada uma das Partes assegurará que as pessoas colectivas consideradas responsáveis nos termos do artigo $22 .^{\circ}$ sejam sujeitas a sanções ou medidas efectivas, proporcionadas e dissuasoras, de natureza penal ou outra, incluindo sanções pecuniárias.

3 - Cada uma das Partes adoptará as medidas que se revelem necessárias para lhe permitir decretar a perda ou de, de outro modo, impedir a utilização dos instrumentos e produtos das infracções penais previstas nos termos do artigo $18 .^{\circ}$ e na alínea a) do artigo $20 . .^{\circ}$ da presente Convenção, ou dos bens cujo valor corresponda a tais produtos.

4 - Cada uma das Partes adoptará as medidas que se revelem necessárias para permitir o encerramento temporário ou definitivo de qualquer estabelecimento utilizado para a prática do tráfico de seres humanos, sem prejuízo dos direitos de terceiros de boa fé, ou para interditar o autor dessa infracção, a título temporário ou definitivo, do exercício da actividade no âmbito da qual a infracção foi cometida. 
Artigo 24.ㅇ

\section{Circunstâncias agravantes}

Cada uma das Partes assegurará que as circunstâncias seguintes serão consideradas circunstâncias agravantes na determinação da sanção a impor relativamente às infracções previstas nos termos do artigo 18. da presente Convenção:

a) A infracção ter colocado em perigo a vida da vítima, deliberadamente ou por negligência grave;

b) A infracção ter sido cometida contra uma criança;

c) A infracção ter sido cometida por um agente público no exercício das suas funções;

d) A infracção ter sido cometida no quadro de uma organização criminosa.

\section{Artigo 25.ำ}

\section{Condenações anteriores}

Cada uma das Partes adoptará as medidas legislativas e outras para que seja prevista a possibilidade de serem tomadas em consideração, no âmbito da ponderação da pena a aplicar, as decisões finais tomadas numa outra Parte relativamente a infracções penais previstas em conformidade com a presente

Convenção.

Artigo 26.

Não aplicação de sanções

Cada uma das Partes deverá prever, em conformidade com os princípios fundamentais do seu sistema jurídico, a possibilidade de não aplicar sanções às vítimas por terem participado em actividades ilícitas desde que a tal tenham sido obrigadas.

\section{CAPÍTULO V \\ Investigação, procedimento criminal e direito processual \\ Artigo 27.ำ \\ Pedidos ex parte e ex officio}

1 - Cada uma das Partes garantirá que as investigações ou os procedimentos relativos a infracções previstas em conformidade com a presente Convenção não ficarão sujeitos a denúncia ou acusação feita por uma vítima, pelo menos nos casos em que a infracção tiver sido cometida, no todo ou em parte, no seu território.

2 - Cada uma das Parte garantirá que as vítimas de uma infracção cometida no território de uma Parte diferente daquela em que residem possam apresentar queixa junto das autoridades competentes do respectivo Estado de residência. Se a autoridade competente junto da qual a queixa foi apresentada não tiver competência na matéria, deverá transmiti-la sem demora à autoridade competente da Parte em cujo 
território a infracção foi cometida. Tal queixa será tratada em conformidade com o direito interno da Parte em que a infracção foi cometida.

3 - Cada uma das Partes garantirá, através de medidas legislativas ou outras e nas condições previstas no seu direito interno, aos grupos, às fundações, às associações ou às organizações não governamentais cujo objectivo seja a luta contra o tráfico de seres humanos ou a protecção dos direitos da pessoa humana a possibilidade de prestar assistência e ou apoiar a vítima, com o consentimento

desta, nos procedimentos criminais relativos às infracções previstas, de

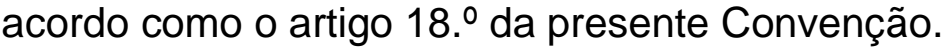

\section{Artigo 28. \\ Protecção das vítimas, testemunhas e pessoas que colaborem com as autoridades judiciárias}

1 - Cada uma das Partes adoptará as medidas legislativas ou outras necessárias para garantir uma protecção efectiva e adequada face às possíveis represálias ou acções de intimidação, em particular durante ou após a conclusão

de investigações e procedimentos criminais contra os autores de infracções, a favor:

a) Das vítimas;

b) Se apropriado, das pessoas que prestem informação acerca da prática de infracções penais previstas no artigo $18 .^{\circ}$ da presente Convenção ou que colaborem, por qualquer outra forma, com as autoridades encarregadas de proceder às investigações e de instaurar procedimentos criminais;

c) Das testemunhas cujos depoimentos digam respeito a infracções criminais previstas no artigo 18. ㅁ da presente Convenção;

d) Se necessário, dos familiares das pessoas referidas nas alíneas a) e c).

2 - Cada uma das Partes adoptará as medidas legislativas ou outras necessárias para garantir e oferecer diversas formas de protecção. Tais medidas poderão incluir a protecção física, a atribuição de um novo local de residência,

a alteração de identidade e a ajuda na obtenção de emprego.

3 - As crianças beneficiarão de medidas de protecção especiais tendo em consideração o seu superior interesse.

4 - Cada uma das Partes adoptará as medidas legislativas ou outras necessárias para garantir, se necessário, uma protecção apropriada aos membros dos grupos, das fundações, das associações ou das organizações não governamentais que exerçam uma ou várias das

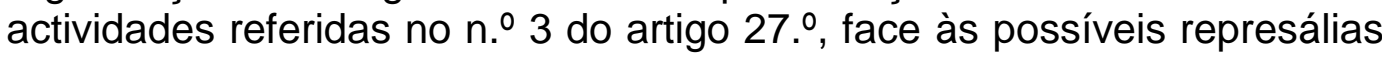
ou acções de intimidação, em particular durante ou após a conclusão de investigações e procedimentos criminais 
contra os autores de infracções.

5 - Cada uma das Parte procurará concluir acordos ou convénios com outros Estados com o objectivo de implementar o disposto no presente artigo.

\section{Artigo 29.ำ}

\section{Autoridades especializadas e serviços de coordenação}

1 - Cada uma das Partes adoptará as medidas necessárias para a especialização de pessoas ou entidades na luta contra o tráfico de seres humanos e na protecção das vítimas. Tais pessoas ou entidades disporão da necessária independência, de acordo com os princípios fundamentais do sistema jurídico dessa Parte, para que possam exercer as suas funções de forma eficaz e estejam livres de qualquer pressão ilícita. As referidas pessoas ou o pessoal das referidas entidades deverão dispor de formação e de recursos financeiros adequados às funções que exercem.

2 - Cada uma das Partes adoptará as medidas necessárias para garantir a coordenação das políticas e das actividades dos serviços integrados na sua administração e dos outros organismos públicos envolvidos na luta contra o tráfico de seres humanos, se necessário criando serviços de coordenação.

3 - Cada uma das Partes assegurará ou reforçará a formação dos funcionários responsáveis pela prevenção e pela luta contra o tráfico de seres humanos, incluindo a formação sobre os direitos da pessoa humana. A formação poderá ser adaptada aos diferentes serviços e incidirá, se for caso disso, sobre os métodos utilizados para impedir o tráfico, perseguir judicialmente os seus autores e proteger os direitos das vítimas, incluindo a protecção das vítimas contra os traficantes.

4 - Cada uma das Partes procurará nomear relatores nacionais ou criar outros mecanismos responsáveis pelo acompanhamento das actividades de luta contra o tráfico desenvolvidas pelas instituições estatais e pela implementação das obrigações previstas na legislação nacional.

\section{Artigo 30. \\ Processos judiciais}

No respeito da Convenção para a Protecção dos Direitos do Homem e

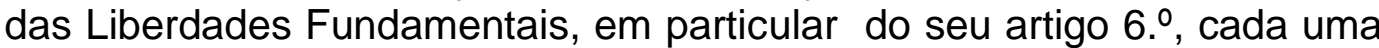
das Partes adoptará as medidas legislativas ou outras necessárias para garantir, no decurso dos procedimentos judiciais:

a) A protecção da vida privada das vítimas e, se for caso disso, da sua identidade;

b) A segurança das vítimas e a sua protecção contra acções de intimidação; 
segundo as condições previstas no seu direito interno e, tratando -se de crianças -vítimas, tendo em particular consideração as necessidades das crianças e assegurando o seu direito a medidas de protecção específicas.

Artigo 31.으.

\section{Competência}

1 - Cada uma das Partes adoptará as medidas legislativas e outras que se revelem necessárias para estabelecer a sua competência relativamente às infracções criminais previstas em conformidade com a presente Convenção, sempre que a infracção for cometida:

a) No seu território; ou

b) A bordo de um navio arvorando o pavilhão dessa Parte; ou

c) A bordo de uma aeronave com matrícula conforme às leis dessa Parte; ou

d) Por um dos seus nacionais, ou por um apátrida com residência habitual no seu território, se a infracção for criminalmente punível no local onde foi cometida ou se

não for da competência territorial de qualquer Estado; e) Contra um dos seus nacionais.

2 - Cada uma das Partes poderá, no momento da assinatura ou do depósito do seu instrumento de ratificação, aceitação, aprovação ou adesão, mediante declaração dirigida ao Secretário -Geral do Conselho da Europa, referir que se reserva o direito de não aplicar, ou de só aplicar em condições e casos específicos, as normas de competência

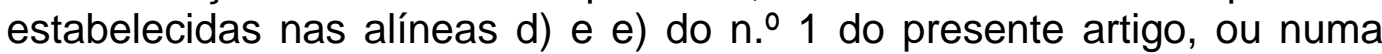
parte das referidas alíneas.

3 - Cada uma das Partes adoptará as medidas necessárias para estabelecer a sua competência relativamente a qualquer uma das infracções referidas na presente Convenção, nos casos em que o presumível autor se encontre no seu território e não possa ser extraditado para uma outra Parte apenas em razão da sua nacionalidade, após um pedido de extradição.

4 - Se várias Partes invocarem competência relativamente a uma presumível infracção prevista de acordo com a presente Convenção, tais Partes acordarão entre si, se tal se mostrar adequado, sobre qual delas está em melhores condições para exercer a acção penal.

5 - Sem prejuízo das regras gerais de direito internacional, a presente Convenção não exclui qualquer competência em matéria criminal exercida por uma Parte em conformidade com o seu direito interno. 


\section{CAPÍTULO VI \\ Cooperação internacional e cooperação \\ com a sociedade civil \\ Artigo 32.. \\ Princípios gerais e medidas de cooperação internacional}

As Partes cooperarão entre si, nos termos da presente Convenção, aplicando os relevantes instrumentos internacionais e regionais aplicáveis, os convénios baseados em legislações uniformes ou recíprocas e os respectivos direitos internos, o mais amplamente possível para:

a) Prevenir e combater o tráfico de seres humanos;

b) Proteger e prestar assistência às vítimas;

c) Proceder a investigações ou instaurar processos relativamente a infracções penais previstas nos termos da presente Convenção.

Artigo 33.ำ

Medidas relativas a pessoas ameaçadas ou desaparecidas

1 - Sempre que uma das Partes, com base em informações de que disponha, tiver motivos razoáveis para crer que a vida, a liberdade ou a integridade física de uma pessoa referida no n. 1 do artigo 28.. corre perigo imediato no território de uma outra Parte, deverá, em tal situação de urgência, transmitir as referidas informações a esta última Parte, para que tome as medidas de protecção adequadas.

2 - As Partes na presente Convenção poderão procurar reforçar a sua cooperação na procura de pessoas desaparecidas, em particular crianças, sempre que as informações disponíveis permitam crer que tais pessoas são vítimas de tráfico de seres humanos. Para esse efeito, as Partes poderão concluir entre si acordos bilaterais ou multilaterais.

\section{Artigo 34.ำ \\ Informações}

1 - A Parte requerida informará, de imediato, a Parte requerente acerca do resultado final das medidas tomadas nos termos do presente capítulo. A Parte requerida informará, de imediato, a Parte requerente acerca de quaisquer circunstâncias que inviabilizem a execução das medidas solicitadas ou que possam retardá -la significativamente.

2 - Qualquer uma das Partes poderá, nos termos do seu direito interno e perante a inexistência de um pedido prévio, transmitir a qualquer outra Parte as informações que tenha obtido no decurso das suas próprias investigações nos casos em que considere que tal poderá auxiliar a Parte destinatária a proceder ou a concluir investigações ou processos com base em infracções penais previstas nos termos da presente Convenção ou que tais informações poderão dar lugar a um pedido de cooperação formulado por essa Parte nos termos do presente capítulo. 
3 - Antes de transmitir tais informações, a Parte que as disponibilizar poderá solicitar que permaneçam confidenciais ou que apenas sejam utilizadas em determinadas condições. Se a Parte destinatária não puder satisfazer tal pretensão, deverá informar a outra Parte de tal impossibilidade, a qual deverá, nesse caso, decidir se as informações em causa deverão ser transmitidas. Caso aceite as informações nas condições estabelecidas, a Parte destinatária ficará vinculada às mesmas.

4 - Todas as informações solicitadas com referência aos artigos 13.․․ $14 .$. e $16 .$. que se mostrem necessárias para a atribuição dos direitos conferidos por tais artigos, serão transmitidas imediatamente após a formulação do pedido da Parte interessada, em conformidade com o artigo 11. 을 da presente Convenção.

Artigo 35.

\section{Cooperação com a sociedade civil}

Cada uma das Partes encorajará as autoridades estaduais, bem como os agentes públicos, a cooperar com as organizações não governamentais, outras organizações relevantes e membros da sociedade civil, por forma a estabelecer

parcerias estratégicas que permitam atingir os objetivos da presente Convenção.

\section{CAPÍTULO VII \\ Mecanismo de acompanhamento \\ Artigo 36. ${ }^{\circ}$ \\ Grupo de Peritos sobre a Luta contra o Tráfico de Seres Humanos}

1 - O Grupo de Peritos sobre o Tráfico de Seres Humanos (adiante denominado «GRETA») supervisionará a implementação da presente Convenção pelas Partes.

2 - O GRETA será composto por um mínimo de 10 e um máximo de 15 membros e contará com uma participação de homens e mulheres e uma participação geográfica equilibradas, dele fazendo igualmente parte peritos com

competência multidisciplinar. Os seus membros serão eleitos pelo Comité das Partes de entre os nacionais dos Estados Partes na presente Convenção e terão um mandato de quatro anos renovável por uma vez.

3 - A eleição dos membros do GRETA assentará nos seguintes princípios:

a) Serão escolhidos de entre personalidades de elevada ética e reconhecida competência em matéria de direitos da pessoa humana, assistência e protecção às vítimas e luta contra o tráfico de seres humanos, ou com experiência profissional nos domínios abrangidos pela presente Convenção; 
b) Terão assento a título individual, serão independentes e imparciais no exercício do seu mandato e estarão disponíveis para exercer as suas funções de forma eficiente;

c) O GRETA não poderá contar com mais de um nacional do mesmo Estado;

d) Deverão representar os principais sistemas jurídicos.

4 - O processo de eleição dos membros do GRETA será fixado pelo Comité de Ministros, após consulta e mediante o acordo unânime das Partes na presente Convenção, no prazo de um ano a contar da data de entrada em vigor da presente Convenção. O GRETA adoptará o seu próprio regulamento interno.

\section{Artigo 37.}

\section{Comité das Partes}

1 - O Comité das Partes será composto pelos representantes no Comité dos Ministros do Conselho da Europa e dos Estados membros Partes na Convenção e pelos representantes das Partes na Convenção que não sejam membros do Conselho da Europa.

2 - O Comité das Partes será convocado pelo Secretário -Geral do Conselho da Europa. A sua primeira reunião terá lugar num prazo de um ano após a entrada em vigor da presente Convenção, com o objectivo de eleger os membros do GRETA. Posteriormente, reunir -se -á a pedido de um terço das Partes, do Presidente do GRETA ou do Secretário -Geral.

3 - O Comité das Partes adoptará o seu próprio regulamente interno.

\section{Artigo 38.ㅇ}

Processo

1 - O processo de avaliação será da responsabilidade das Partes na Convenção, repartido por ciclos cuja duração será estabelecida pelo GRETA. No início de cada ciclo, o GRETA seleccionará as disposições específicas nas quais

se baseará o processo de avaliação.

2 - O GRETA estabelecerá os meios mais apropriados para proceder a tal avaliação. O GRETA poderá, em particular, adoptar um questionário para cada um dos ciclos, o qual poderá servir de base à avaliação da implementação da presente Convenção pelas Partes. O questionário será dirigido a todas as Partes. As Partes responderão ao questionário, bem como a qualquer outro pedido de informação formulado pelo GRETA.

3 - O GRETA poderá solicitar informações junto da sociedade civil.

4 - Subsidiariamente, o GRETA poderá organizar, em cooperação com as autoridades nacionais e 0 «elemento de contacto» designado por estas e, se necessário, com a assistência de peritos nacionais independentes, visitas aos 
respectivos países. No decurso de tais visitas, o GRETA poderá ser assistido por especialistas em áreas específicas.

5 - O GRETA preparará um projecto de relatório contendo a sua análise acerca da implementação das disposições em que a avaliação se baseia, bem como as suas sugestões e propostas relativamente à forma como a Parte a que respeita poderá tratar os problemas identificados.

Aquele projecto será transmitido à Parte sob avaliação para apresentar os seus comentários. Estes serão tidos em consideração pelo GRETA ao elaborar o seu relatório.

6 - Nesta base, o GRETA adoptará o seu relatório e as suas conclusões sobre as medidas tomadas pela Parte a que respeita para implementar as disposições da presente Convenção. O relatório e as conclusões serão remetidos à referida Parte e ao Comité das Partes. O relatório e as conclusões do GRETA serão tornados públicos após a sua adopção juntamente com os eventuais comentários da mesma Parte.

7 - Sem prejuízo do processo previsto nos no 1 a 6 do presente artigo, o Comité das Partes poderá formular, com base no relatório e nas conclusões do GRETA, recomendações dirigidas à referida Parte:

a) relativamente às medidas a tomar para implementar as conclusões do GRETA, se necessário fixando uma data para apresentação de informações sobre tal implementação; e

b) tendo por objectivo promover a cooperação com tal Parte com vista à implementação da presente Convenção.

\section{CAPÍTULO VIII}

\section{Relação com outros instrumentos internacionais Artigo 39..}

\section{Relação com o Protocolo Adicional à Convenção das Nações Unidas contra a Criminalidade Transnacional Organizada Relativo à Prevenção, à Repressão e à Punição do Tráfico de Pessoas, em especial de Mulheres e Crianças.}

A presente Convenção não afectará os direitos e as obrigações decorrentes das disposições do Protocolo Adicional à Convenção das Nações Unidas contra a Criminalidade Transnacional Organizada Relativo à Prevenção, à Repressão e à Punição do Tráfico de Pessoas, em especial de Mulheres e Crianças. A presente Convenção tem por finalidade o reforço da protecção concedida pelo Protocolo e o desenvolvimento dos princípios nele enunciados.

\section{Artigo $40^{\circ}$}

\section{Relação com outros instrumentos internacionais}

1 - A presente Convenção não afectará os direitos e obrigações decorrentes de outros instrumentos internacionais de que as Partes sejam ou venham a ser Partes e que contenham disposições relativas às 
matérias por ela regidas e que garantam maior protecção e assistência às vítimas de tráfico de seres humanos.

2 - As Partes na presente Convenção poderão concluir entre si acordos bilaterais ou multilaterais relativos às questões reguladas pela presente Convenção, visando completar ou reforçar as disposições desta ou facilitar a aplicação dos princípios nela consagrados.

3 - As Partes que sejam membros da União Europeia aplicarão, nas suas relações mútuas, as normas da Comunidade e da União Europeia na medida em que existam normas da Comunidade ou da União Europeia que regulem determinado tema em particular e que sejam aplicáveis ao caso concreto, sem prejuízo do objecto e da finalidade da presente Convenção e da sua integral aplicação relativamente às outras Partes.

4 - Nenhuma disposição da presente Convenção afectará os direitos, obrigações e responsabilidades dos Estados e dos cidadãos nos termos do direito internacional, incluindo o direito internacional humanitário e o direito internacional relativo aos direitos do homem e, em particular, se aplicáveis, a Convenção de 1951 e o Protocolo de 1967 relativos ao estatuto dos refugiados bem como o princípio de non refoulement aí enunciado.

\section{CAPÍTULO IX \\ Alterações à Convenção \\ Artigo 41. \\ Alterações}

1 - Qualquer alteração à presente Convenção proposta por uma Parte deverá ser comunicada ao Secretário -Geral do Conselho da Europa e transmitida por este aos Estados membros do Conselho da Europa, a qualquer outro Estado

signatário, a qualquer Estado Parte, à Comunidade Europeia e a qualquer Estado convidado a assinar a presente Convenção nos termos do artigo 42. ${ }^{\circ}$, assim como a qualquer Estado que tenha sido convidado a aderir à presente Convenção nos termos do artigo $43 .{ }^{\circ}$

2 - Qualquer alteração proposta por uma Parte será comunicada ao GRETA, que transmitirá ao Comité de Ministros o seu parecer sobre a alteração proposta.

3 - O Comité de Ministros analisará a alteração proposta e o parecer apresentado pelo GRETA; após consulta às Partes na Convenção e tendo obtido o acordo unânime, o Comité poderá adoptar tal alteração.

4 - O texto de qualquer alteração adoptada pelo Comité de Ministros nos termos do n. 03 do presente artigo será comunicado às Partes, com vista à sua aceitação.

5 - Qualquer alteração adoptada nos termos do $n . .^{\circ} 3$ do presente artigo entrará em vigor no 1. dia do mês seguinte ao termo de um período de 
três meses após a data em que todas as Partes tenham informado o Secretário -Geral da sua aceitação

\section{CAPÍTULOX \\ Cláusulas finais \\ Artigo 42. \\ Assinatura e entrada em vigor}

1 - A presente Convenção será aberta à assinatura dos Estados membros do Conselho da Europa, dos Estados não membros que tenham participado na sua elaboração e da Comunidade Europeia.

2 - A presente Convenção será sujeita a ratificação, aceitação ou aprovação. Os instrumentos de ratificação, aceitação ou aprovação serão depositados junto do Secretário -Geral do Conselho da Europa.

3 - A presente Convenção entrará em vigor no $1 .$. dia do mês seguinte ao termo de um período de três meses após a data em que 10 signatários, dos quais pelo menos 8 sejam membros do Conselho da Europa, tenham exprimido o seu consentimento em ficarem vinculados à presente Convenção, em conformidade com o disposto no $\mathrm{n} . \stackrel{0}{2}$.

4 - Relativamente a qualquer Estado referido no n.- 1 ou à Comunidade Europeia que exprima posteriormente o seu consentimento em ficar vinculado à presente Convenção, esta entrará em vigor no 1.ำ dia do mês seguinte ao termo de um período de três meses após a data do depósito do instrumento de ratificação, aceitação ou aprovação.

\section{Artigo 43.ำ \\ Adesão à Convenção}

1 - Após a entrada em vigor da presente Convenção, o Comité de Ministros do Conselho da Europa poderá, após ter consultado as Partes na presente Convenção e ter obtido o acordo unânime destas, convidar qualquer Estado não membro do Conselho que não tenha participado na sua elaboração a aderir à presente Convenção. A decisão será tomada pela maioria prevista no artigo 20.․ alínea d), do Estatuto do Conselho da Europa e por unanimidade dos representantes dos Estados Contratantes com assento no Comité de Ministros.

2 - Relativamente a qualquer Estado que a ela adira, a presente Convenção entrará em vigor no $1 .^{\circ}$ dia do mês seguinte ao termo de um período de três meses após a data do depósito do instrumento de adesão junto do Secretário-

-Geral do Conselho da Europa. 
Artigo $44 .^{\circ}$

\section{Aplicação territorial}

1 - Qualquer Estado ou a Comunidade Europeia poderá, no momento da assinatura ou do depósito do seu instrumento de ratificação, aceitação, aprovação ou adesão, indicar o território ou os territórios aos quais se aplicará a presente Convenção.

2 - Qualquer Parte poderá, em qualquer momento posterior, mediante declaração dirigida ao Secretário -Geral do Conselho da Europa, estender a aplicação da presente Convenção a qualquer outro território indicado na declaração, relativamente ao qual assegure as relações internacionais e em nome do qual esteja autorizado a assumir compromissos.

A Convenção entrará em vigor, relativamente a esse território, no primeiro dia do mês seguinte ao termo de um período de três meses após a data de recepção da

declaração pelo Secretário -Geral.

3 - Qualquer declaração feita nos termos dos dois números anteriores poderá ser retirada, no que respeita a qualquer território nela indicado, mediante notificação dirigida ao Secretário -Geral do Conselho da Europa. A retiradaproduzirá efeitos no $1 .{ }^{\circ}$ dia do mês seguinte ao termo de um período de três meses após a data de recepção da notificação pelo Secretário -Geral.

\section{Artigo 45.9}

\section{Reservas}

Nenhuma reserva à presente Convenção será aceite, com excepção da prevista no n. 2 do artigo $31 .$.

Artigo $46 .{ }^{\circ}$

Denúncia

1 - Qualquer Parte poderá, em qualquer momento, denunciar a presente Convenção mediante notificação dirigida ao Secretário -Geral do Conselho da Europa.

2 - A denúncia produzirá efeitos no 1. dia do mês seguinte ao termo de um período de três meses após a data de recepção da notificação pelo Secretário -Geral.

\section{Artigo 47.}

\section{Notificação}

1 - O Secretário -Geral do Conselho da Europa notificará os Estados membros do Conselho da Europa, qualquer Estado signatário, qualquer Estado Parte, a Comunidade Europeia, qualquer Estado que tenha sido convidado a aderir à presente Convenção nos termos do artigo 42.. 
como qualquer Estado convidado a aderir à Convenção nos termos do artigo 43.:

a) De qualquer assinatura;

b) Do depósito de qualquer instrumento de ratificação, aceitação, aprovação ou adesão;

c) De qualquer data de entrada em vigor da presente Convenção, em conformidade com os artigos $42 . .0$ e $43 .$. ;

d) De qualquer alteração adoptada nos termos do artigo $41 .$. , bem como da data da entrada em vigor da referida alteração;

e) De qualquer denúncia feita nos termos do artigo 46..

f) De qualquer outro acto, notificação ou comunicação referentes à presente Convenção;

g) De qualquer reserva nos termos do artigo 45.0

Em fé do que, os abaixo assinados, devidamente autorizados para o efeito, assinaram a presente Convenção.

Feito em Varsóvia, a 16 de Maio de 2005, em francês e inglês, fazendo ambos os textos igualmente fé, num único exemplar, que será depositado nos arquivos do Conselho da Europa. O Secretário -Geral do Conselho da Europa enviará uma cópia autenticada a cada um dos Estados membros do Conselho da Europa, aos Estados não membros que tenham participado na elaboração da presente Convenção, à Comunidade Europeia e a qualquer outro Estado convidado a aderir à presente Convenção pela Resolução da Assembleia da República n.․ 11/88, publicada no Diário da República, 1. a série, n.. 118 , de 21 de Maio de 1988, e ratificada pelo Decreto do Presidente da República n. $.57 / 88$, publicado no Diário da República, 1. a série, n. 166, de 20 de Julho de 1988, tendo depositado o seu instrumento de ratificação em 9 de Fevereiro de 1989, conforme aviso publicado no Diário da República, 1. série, n. .128 , de 5 de Junho de 1989.

Direcção -Geral de Política Externa, 3 de Janeiro de 2008. - O Subdirector -Geral para os Assuntos Multilaterais, António Ricoca Freire.

\section{8}

Anexo 8 - LEI N 11.106, de 28 de Março de 2005

Altera os arts. $148,215,226,227$, 231 e acrescenta 0 art. 231-A ao Decreto-Lei $\mathrm{n}^{\circ} 2.848$, de 7 de dezembro de 1940 - Código Penal e dá outras providências.

O PRESIDENTE DA REPÚBLICA. Faço saber que o Congresso Nacional decreta e eu sanciono a seguinte Lei: 
Art. $1^{\circ}$ Os arts. 148, 215, 216, 226, 227 e 231 do Decreto-Lei $n^{\circ} 2.848$, de 7 de dezembro de 1940 - Código Penal, passam a vigorar com a seguinte redação:

"Art. 148

$\S 1^{\circ}$

I - se a vítima é ascendente, descendente, cônjuge ou companheiro do agente ou maior de 60 (sessenta) anos;

IV - se o crime é praticado contra menor de 18 (dezoito) anos;

$\mathrm{V}$ - se o crime é praticado com fins libidinosos.

\section{"Posse sexual mediante fraude}

Art. 215. Ter conjunção carnal com mulher, mediante fraude:

\section{"Atentado ao pudor mediante fraude}

Art. 216. Induzir alguém, mediante fraude, a praticar ou submeter-se à prática de ato libidinoso diverso da conjunção carnal:

Parágrafo único. Se a vítima é menor de 18 (dezoito) e maior que 14 (quatorze) anos:

Pena - reclusão, de 2 (dois) a 4 (quatro) anos." (NR)

"Art. 226. A pena é aumentada:

I - de quarta parte, se o crime é cometido com o concurso de 2 (duas) ou mais pessoas;

II - de metade, se o agente é ascendente, padrasto ou madrasta, tio, irmão, cônjuge,

companheiro, tutor, curador, preceptor ou empregador da vítima ou por qualquer outro título tem autoridade sobre ela;

III - (revogado)." (NR)

\section{"CAPÍTULO V \\ DO LENOCÍNIO E DO TRÁFICO DE PESSOAS}

Art. 227.

$\$ 1^{\circ}$ Se a vítima é maior de 14 (quatorze) e menor de 18 (dezoito) anos, ou se o agente é seu ascendente, descendente, cônjuge ou companheiro, irmão, tutor ou curador ou pessoa a quem esteja confiada para fins de educação, de tratamento ou de guarda:

\section{"Tráfico internacional de pessoas}

Art. 231. Promover, intermediar ou facilitar a entrada no território nacional, de pessoa que venha exercer a prostituição ou a saída de pessoa para exercê-la no estrangeiro:

Pena - reclusão, de 3 (três) a 8 (oito) anos, e multa.

$\S 1^{\circ}$

Pena - reclusão, de 4 (quatro) a 10 (dez) anos, e multa. 
$\S 2^{\circ}$ Se há emprego de violência, grave ameaça ou fraude, a pena é de reclusão, de 5 (cinco) a 12 (doze) anos, e multa, além da pena correspondente à violência.

$\S 3^{\circ}$ (revogado).” (NR)

Art. $2^{\circ}$ O Decreto-Lei $n^{\circ} 2.848$, de 7 de dezembro de 1940 - Código Penal, passa a vigorar acrescido do seguinte art. 231 - A:

\section{"Tráfico interno de pessoas}

Art. 231 - A. Promover, intermediar ou facilitar, no território nacional, o recrutamento, o transporte, a transferência, o alojamento ou o acolhimento da pessoa que venha exercer a prostituição:

Pena - reclusão, de 3 (três) a 8 (oito) anos, e multa.

Parágrafo único. Aplica-se ao crime de que trata este artigo o disposto nos $\S \S 1^{\circ}$ e $2^{\circ}$ do

art. 231 deste Decreto-Lei."

Art. $3^{\circ} \mathrm{O}$ Capítulo $\mathrm{V}$ do Título $\mathrm{VI}$ - DOS CRIMES CONTRA OS COSTUMES da Parte Especial do Decreto-Lei $n^{\circ} 2.848$, de 7 de dezembro de 1940 - Código Penal, passa a vigorar com o seguinte título: "DO LENOCÍNIO E DO TRÁFICO DE PESSOAS".

Art. $4^{\circ}$ Esta Lei entra em vigor na data de sua publicação.

Art. $5^{\circ}$ Ficam revogados os incisos VII e VIII do art. 107, os arts. 217, 219, 220, 221, 222, o inciso III do caput do art. 226, o $\S 3^{\circ}$ do art. 231 e o art. 240 do Decreto-Lei $n^{\circ} 2.848$, de 7 de dezembro de 1940 - Código Penal.

Brasília, 28 de março de $2005 ; 184^{\circ}$ da Independência e $117^{\circ}$ da República.

LUIZ INÁCIO LULA DA SILVA

Márcio Tomaz Bastos

José Dirceu de Oliveira e Silva

\section{9}

Anexo 9 - Política Nacional de Enfrentamento ao Tráfico de Pessoas

Excelentíssimo Senhor Presidente da República,

Submetemos à elevada apreciação de Vossa Excelência a anexa proposta de Decreto que "Aprova a Política Nacional de Enfrentamento ao Tráfico de Pessoas e institui Grupo de Trabalho Interministerial com o objetivo de elaborar proposta do Plano Nacional de Enfrentamento ao Tráfico de Pessoa. 
O tráfico de pessoas tem se tornado, nos últimos anos, um problema de imensões cada vez mais alarmantes. Dados da Organização Internacional do Trabalho (OIT) assinalam que durante o ano de 2005 o tráfico de pessoas fez aproximadamente 2,4 milhões de vítimas. A OIT estima que $43 \%$ dessas vítimas sejam subjugadas para exploração sexual e $32 \%$ para a exploração econômica. O tráfico de pessoas é também uma das atividades criminosas mais lucrativas, podendo o lucro anual chegar a 31,6 bilhões de dólares. Levantamento do Escritório das Nações Unidas contra Drogas e Crimes (UNODC) mostra também que, para cada ser humano transportado de um país para o outro, o lucro das redes criminosas pode chegar a US\$30 mil por ano.

No Brasil, ainda há poucos estudos especializados sobre o tema. Uma das pesquisas mais importantes e de abrangência nacional é a Pesquisa sobre o Tráfico de Mulheres, Crianças e Adolescentes para fins de Exploração Sexual Comercial (PESTRAF), realizada em 2002.

Esse estudo apontou a existência de 241 rotas de tráfico interno e internacional de crianças, adolescentes e mulheres brasileiras, evidenciando a gravidade do problema no país.

A esse respeito, merecem destaque também os trabalhos conduzidos pela Comissão Parlamentar mista de Inquérito (CPMI) do Congresso Nacional, instituída em 2003, com o propósito de investigar as situações de violência e as redes de exploração sexual de crianças e adolescentes no Brasil. Das diversas reuniões e audiências públicas realizadas pela CPMI, resultou um relatório final que contém uma série de proposições legislativas, baseadas nas conclusões das investigações feitas, algumas das quais já foram contempladas nas recentes alterações do Código Penal Brasileiro e do Estatuto da criança e do Adolescente.

Outra inovação recente no tratamento dessa questão no Brasil foi a inclusão, no Plano Plurianual para os anos de 2004-2007, de duas ações específicas, a cargo do Ministério da Justiça, voltadas para o enfrentamento do tráfico de pessoas: uma de capacitação de profissionais da rede de atendimento às vítimas e outra de realização de diagnósticos sobre o tráfico de seres humanos no país.

De se notar também que, com a edição da Lei $n^{\circ} 11.106$ de 28 de março de 2005, houve importantes mudanças na legislação penal brasileira no tocante ao tráfico de pessoas. A redação dada ao artigo 231 do Código Penal foi alterada para abarcar o tráfico internacional de pessoas, não apenas de mulheres. Dentre os aspectos inovadores, destaca-se ainda a inclusão de um tipo penal específico para o tráfico de pessoas, quando este é desenvolvido em âmbito nacional apenas, sem ramificações internacionais. Assim, dispõe o novo artigo 231-A relativo ao tráfico interno de pessoas: "promover, intermediar ou facilitar, no território nacional, o recrutamento, o transporte, a transferência, o alojamento ou o acolhimento de pessoa que venha a exercer a prostituição", prevendo pena de reclusão de 3 a 8 anos e multa. 
Embora muitos casos referentes ao tráfico de pessoas envolvam vítimas brasileiras, sabe-se que o Brasil tem sido também o país de destino e de trânsito de muitas vítimas, quer sejam mulheres e adolescentes trazidas para fins de exploração sexual comercial, quer sejam homens trabalhadores que são transportados e mantidos em situações análogas a de escravo.

Portanto, fica evidente que, para que esse problema seja enfrentado de forma efetiva, faz-se necessário um esforço bem articulado e coordenado em níveis local, nacional, internacional e regional dos governos e da sociedade civil. Para além de combater o crime organizado internacional, há que se proteger e promover o respeito aos direitos humanos das vítimas de tráfico, independente de sua nacionalidade, situação migratória ou qualquer outro status. E em matéria de promoção e proteção dos direitos humanos, ao ratificar diversos tratados internacionais, incluindo os três principais tratados gerais de proteção (os dois Pactos de Direitos Humanos das Nações Unidas e a Convenção Americana sobre Direitos Humanos), o Brasil assumiu diversos compromissos e obrigações internacionais afetas à proteção aos direitos humanos em geral, mas também relacionadas às prevenção e ao combate ao tráfico de pessoas, bem como à proteção das vítimas.

Em primeiro lugar, vale destacar que, em 29 de janeiro de 2004, o governo brasileiro ratificou o Protocolo Adicional à Convenção das Nações Unidas contra o Crime Organizado Transnacional relativo à Prevenção, Repressão e Punição do Tráfico de Pessoas, em Especial mulheres e Crianças, adotado em Nova York em 15 de novembro de 2000, promulgado pelo Decreto $n^{\circ} 5.017$, de 12 de março de 2004. Tratase de um instrumento internacional que contém normas e medidas relativas a todos os aspectos relacionados ao tráfico de pessoas, quais sejam, a prevenção e o combate ao tráfico, bem como a prevenção e a assistência às vítimas.

É sabido que o tráfico de pessoas faz de suas maiores vítimas as mulheres, crianças e adolescentes. A esse respeito, cumpre observar que o Brasil é Parte dos principais tratados internacionais relativos à proteção dos direitos da mulher.

Em $1^{\circ}$ de fevereiro de 1984, o governo brasileiro ratificou a Convenção das nações Unidas sobre a Eliminação de Todas as Formas de Discriminação contra a mulher (1979). Posteriormente, em 28 de junho de 2002, tornou-se parte também do Protocolo Facultativo à Convenção das Nações Unidas sobre a Eliminação de Todas as Formas de Discriminação Contra a Mulher (1979). No

sistema interamericano de proteção dos direitos humanos, vale destacar que o Brasil é também Estado Parte da Convenção Interamericana para Prevenir, Punir e Erradicar a Violência contra a mulher (1994). 
Em se tratando de proteção dos direitos das crianças e adolescentes, o governo brasileiro também se alinha aos instrumentos e às normas internacionalmente reconhecidas, tendo já ratificado a Convenção das Nações Unidas sobre os Direitos da Criança sobre a Venda de Crianças, a prostituição Infantil e a pornografia Infantil (1999), bem como a Convenção Interamericana sobre o Tráfico Internacional de Menores (1994).

Por fim, dado que o tráfico de pessoas engloba também a exploração de trabalho ou serviços forçados, cumpre retomar a Convenção Suplementar sobre a Abolição da Escravatura, do Tráfico de Escravos e das Instituições e Práticas Análogas à Escravatura, bem como as principais convenções da OIT sobre essa matéria, em especial a Convenção $n^{\circ} 29$ relativa ao Trabalho Forçado ou Obrigatório (1930); a Convenção n 105 referente à Abolição do Trabalho Forçado (1959); e a Convenção $n^{\circ} 182$ referente às Piores Formas de Trabalho Infantil (1999), todas já ratificadas pelo Brasil.

Com base nessas considerações, e amparado na legislação pátria e nos instrumentos internacionais supracitados, construiu-se o presente projeto que ora submetemos ao apreço de Vossa Excelência. Resultado de um esforço conjunto, a presente proposta de Decreto foi elaborada por um Grupo de Trabalho formado por representantes do Poder Executivo Federal, do Ministério Público Federal e do Ministério Público do Trabalho, cuja coordenação esteve ao cargo do Ministério da justiça, da Secretaria Especial de Direitos Humanos da Presidência da República e da Secretaria Especial de Políticas para as mulheres da Presidência da República.

Inicialmente, em 2 de fevereiro, realizou-se reunião interministerial em que foi criado o referido Grupo de Trabalho com a função de elaborar uma proposta de política nacional referente ao tráfico de pessoas. Em reunião realizada no dia 17 de fevereiro, o Grupo de Trabalho optou por formar três subgrupos temáticos, que ficaram responsáveis pelos trabalhos relativos aos eixos de prevenção; atendimento às vítimas e defesa; e responsabilização, respectivamente. Os subgrupos reuniram-se de forma independente até a apresentação de suas conclusões nas últimas reuniões do Grupo de Trabalho, ocorridas respectivamente nos dias 23 de março, 11 e 17 de abril do corrente ano.

No dia 10 de maio de 2006, a proposta de Política nacional de Enfrentamento ao Tráfico de Pessoas, resultante dos trabalhos supracitados, foi apresentada e aprovada em nova reunião do governo. $\mathrm{Na}$ ocasião, deliberou-se por submeter a proposta de Política Nacional à consulta pública, de forma a conferir legitimidade à Política então traçada e garantir participação e mobilização da sociedade civil. Assim, a proposta esteve em consulta pública, disponível no site do Ministério da justiça e da Secretaria Especial de Políticas para as mulheres, no período de 13 a 30 de junho de 2006, segundo publicação no Diário Oficial da União de 13 de junho do corrente. 
Para aprofundar a discussão do tema e assegurar a participação da sociedade civil, realizou-se no dia 28 de junho, na sede da ProcuradoriaGeral da República, o Seminário Nacional "A Política Nacional de Enfrentamento ao Tráfico de pessoas". Realizou-se, assim, um importante debate com a sociedade civil sobre as contribuições e sugestões que foram apresentadas durante a consulta pública. Participaram do seminário representantes de diversas organizações não-governamentais, organismos internacionais, governos federal e estaduais, além de pesquisadores e outros técnicos que trabalham com o tema do tráfico de pessoas no Brasil.

Dessa forma, o projeto de Decreto submetido à consideração de Vossa xcelência abrange as contribuições e os produtos finais da referida consulta pública e do Seminário Nacional realizado em junho deste ano.

A Política Nacional de Enfrentamento ao tráfico de Pessoas, anexa ao Decreto, está dividida em três capítulos. O Capítulo I dispõe sobre sua finalidade precípua, qual seja, traçar diretrizes, princípios e ações no enfrentamento ao tráfico de pessoas. Na primeira parte, defini-se ainda a expressão "tráfico de pessoas", tal como prevêem os principais instrumentos internacionais, notadamente o Protocolo Adicional à Convenção das Nações Unidas contra o Crime Organizado Transnacional Relativo à Prevenção, Repressão e Punição do Tráfico de Pessoas, em Especial Mulheres e crianças, e a legislação brasileira referente ao assunto.

Cumpre destacar que, ao se adotar a expressão "tráfico de pessoas" constante no aludido Protocolo, fez-se mister especificar e adaptar a definição ao ordenamento jurídico pátrio.

Assim, a redação dada ao art. $2^{\circ}, \S \S 1^{\circ}$ a $6^{\circ}$, responde a essa necessidade, buscando evitar eventuais descompassos da definição adotada com a ordem vigente.

O Capítulo II trata dos princípios e das diretrizes, gerais e específicas, que conformam e orientam a Política Nacional de Enfrentamento ao Tráfico de Pessoas. Fiel aos princípios gerais consagrados na Constituição Federal e nos instrumentos internacionais de direitos humanos dos quais o Brasil é parte, o núcleo da Política Nacional estruturou-se em torno de três grandes eixos de atuação:prevenção ao tráfico de pessoas (art. $5^{\circ}$ ); repressão ao tráfico de pessoas e responsabilização de seus autores (art. $\left.6^{\circ}\right)$; e atenção às vítimas $\left(\operatorname{art.~} 7^{\circ}\right)$.

Essas diretrizes específicas são, no capítulo seguinte (Capítulo III), desdobradas em ações de competência de órgãos e entidades públicas das áreas de justiça e segurança pública, relações exteriores, educação, saúde, assistência social, promoção da igualdade racial, trabalho e emprego, desenvolvimento agrário, direitos humanos, proteção e promoção dos direitos da mulher, turismo e cultura. Dado o seu caráter complexo e multidimencional, o enfrentamento ao tráfico de pessoas 
requer ações conjuntas e coordenadas entre as várias áreas afetas ao problema. Portanto, para a construção das ações listadas nesse capítulo, partiu-se de um levantamento das atividades desenvolvidas pelo Poder Executivo Federal nessas diversas áreas.

Finalmente, vale ressaltar que o capítulo III, ao cuidar das Ações, servirá de substratum para a construção do Plano Nacional de Enfrentamento ao Tráfico de Pessoas, próxima etapa desse processo. O projeto de Decreto prevê, portanto, a criação de um Grupo de Trabalho interministerial cuja competência será a elaboração do Plano Nacional de Enfrentamento ao tráfico de pessoas. Com o Plano Nacional, pretender-se-á dar real concretude e efetividade às ações preventivas, repressivas e de atenção às vítimas que consubstanciam a Política Nacional, ao se estabelecer propostas, prazos definidos e responsáveis pela execução de cada ação.

Estas são, Senhor Presidente, as razões que nos levam a submeter a anexa proposta de Decreto ao descortino de vossa Excelência, na certeza de que, se aceita, há de constituir um importante marco no tratamento desse problema pelo Estado brasileiro.

\author{
Respeitosamente, \\ MÁRCIO THOMAZ BASTOS \\ Ministro de Estado da Justiça \\ NILCÉA FREIRE \\ Secretária Especial de Políticas para as Mulheres da Presidência da \\ República \\ PAULO VANNUCHI \\ Secretário Especial dos Direitos Humanos da Presidência da República
}

DECRETO N 5.948, DE 26 DE OUTUBRO DE 2006.

Aprova a Política Nacional de Enfrentamento ao Tráfico de Pessoas e

institui Grupo de Trabalho Interministerial com o objetivo de elaborar proposta de Plano Nacional de Enfrentamento ao Tráfico de Pessoa PNETP.

O PRESIDENTE DA REPÚBLICA, no uso da atribuição que lhe confere o art. 84, inciso VI, alínea "a", da Constituição,

\title{
DECRETA:
}

Art. $1^{\circ}$ Fica aprovada a Política Nacional de Enfrentamento ao Tráfico de Pessoas, que tem por finalidade estabelecer princípios, diretrizes e ações de prevenção e repressão ao tráfico de pessoas e atendimento às vítimas, conforme Anexo a este Decreto. 
Art. $2^{\circ}$ Fica instituído, no âmbito do Ministério da Justiça, o Grupo de Trabalho Interministerial com a finalidade de elaborar proposta de Plano Nacional de Enfrentamento ao Tráfico de Pessoas - PNETP.

Art. $3^{\circ} \mathrm{O}$ Grupo de Trabalho será integrado por um representante, titular e suplente, de cada órgão a seguir indicado:

I - Secretaria Especial de Direitos Humanos da Presidência da República; II - Secretaria Especial de Políticas para as Mulheres, da Presidência da República;

III - Secretaria Especial de Políticas de Promoção da Igualdade Racial da Presidência da República;

IV - Casa Civil da Presidência da República;

V - Ministério da Justiça;

$\mathrm{VI}$ - Ministério do Desenvolvimento Social e Combate á Fome;

VII - Ministério da Saúde;

VIII - Ministério do Trabalho e Emprego;

IX - Ministério do Desenvolvimento Agrário;

$X$ - Ministério da Educação;

XI - Ministério das Relações Exteriores;

XII - Ministério do Turismo;

XIII - Ministério da Cultura; e

XIV - Advocacia-Geral da União.

$\S 1^{\circ} \mathrm{O}$ Grupo de Trabalho será coordenado conjuntamente pelos representantes da Secretaria Especial de Políticas para as Mulheres, da Secretaria Especial dos Direitos Humanos e do Ministério da Justiça.

$\S 2^{\circ}$ Os membros do Grupo de Trabalho serão indicados pelos titulares dos órgãos representados e designados em portaria conjunta do Secretário Especial de Políticas para as Mulheres, do Secretário Especial dos Direitos Humanos e do Ministro de Estado da Justiça.

$\S 3^{\circ}$ A coordenação do Grupo de Trabalho poderá convidar representantes de outros órgãos e entidades da Administração Pública e da sociedade civil para participar de suas atividades.

$\S 4^{\circ}$ O Ministério Público Federal e o Ministério Público do Trabalho serão convidados a fazer parte do Grupo de Trabalho.

Art. $4^{\circ} \mathrm{O}$ Grupo de Trabalho poderá instituir comissões ou subgrupos temáticos com a função de colaborar, no que couber, para o cumprimento das suas atribuições, sistematizar as informações recebidas e subsidiar a elaboração de PNETP.

Art. $5^{\circ}$ Compete ao Grupo de Trabalho:

I - promover a difusão da Política Nacional de Enfrentamento ao Tráfico de Pessoas junto a órgãos e entidades governamentais e nãogovernamentais, fomentando a discussão para subsidiar a elaboração do PNETP;

II - estabelecer a metodologia para a elaboração da proposta de PNETP; 
III - definir as metas, prioridades e ações de PNETP; e

IV - elaborar a proposta de PNETP.

Art. $6^{\circ}$ A Secretaria Especial de Políticas para as Mulheres, a Secretaria Especial dos Direitos Humanos e o Ministério da Justiça prestarão apoio técnico e administrativo ao Grupo de Trabalho.

Art. $7^{\circ} \bigcirc$ Grupo de Trabalho deverá apresentar relatório final com proposta de PNETP ao Secretário Especial de Políticas para as Mulheres, ao Secretário Especial dos Direitos Humanos e ao Ministro de Estado da Justiça.

Art. $8^{\circ} \mathrm{O}$ Grupo de Trabalho terá prazo de noventa dias, a contar da sua instalação, para conclusão dos seus trabalhos, prorrogável por mais trinta dias, pelo Secretário Especial de Políticas para as Mulheres, pelo Secretário Especial dos Direitos Humanos e pelo Ministro de Estado da Justiça, mediante justificativa apresentada pelos Coordenadores do colegiado.

Art. $9^{\circ}$ A participação no Grupo de Trabalho é de relevante interesse público e não será remunerada.

Art. $10^{\circ}$ Este decreto entra em vigor na data de sua publicação.

Brasília, 26 de outubro de $2006 ; 185^{\circ}$ da Independência e $118^{\circ}$ da

República.

\section{POLÍTICA NACIONAL DE ENFRENTAMENTO AO TRÁFICO DE PESSOAS}

\section{Capítulo I Disposições Gerais}

Art. $1^{\circ}$ A Política Nacional de Enfrentamento ao Tráfico de Pessoas tem por finalidade estabelecer princípios, diretrizes e ações de prevenção e repressão ao tráfico de pessoas, de responsabilização de seus autores e de atenção às vítimas, conforme as normas e instrumentos nacionais e internacionais de direitos humanos e legislação pátria.

Art. $2^{\circ}$ Para os efeitos desta Política, adota-se a expressão "tráfico de pessoas" conforme o Protocolo Adicional à Convenção das Nações Unidas contra o Crime Organizado Transnacional Relativo à Prevenção, Repressão e punição do Tráfico de Pessoas, em especial Mulheres e Crianças, que a define como o recrutamento, 0 transporte, a transferência, o alojamento ou o acolhimento de pessoas, recorrendo à ameaça ou uso da força ou a outras formas de coação, ao rapto, à fraude, ao engano, ao abuso de autoridade ou à situação de vulnerabilidade ou à entrega ou aceitação de pagamentos ou benefícios para obter o consentimento de uma pessoa que tenha autoridade sobre outra para fins de exploração. A exploração incluirá, no mínimo, a exploração da 
prostituição de outrem ou outras formas de exploração sexual, o trabalho ou serviços forçados, escravatura ou práticas similares à escravatura, a servidão ou a remoção de órgãos.

$\S 1^{\circ} \mathrm{O}$ termo "criança" descrito no caput deve ser entendido como "criança e adolescente", de acordo com a Lei n 8.069, de 13 de julho de 1990, Estatuto da Criança e do Adolescente.

$\S 22^{\circ} \mathrm{O}$ termo "rapto" descrito no caput deste artigo deve ser entendido como a conduta definida no artigo 148 do Decreto-Lei $n^{\circ} 2.848$, de 7 de dezembro de 1940, Código Penal brasileiro, referente ao sequestro e cárcere privado.

$\S 3^{\circ} \mathrm{A}$ expressão "escravatura ou práticas similares à escravatura" deve ser entendida como:

a) a conduta definida no artigo 149 do Decreto-Lei $n^{\circ} 2.848$, de 7 de dezembro de 1940,Código Penal Brasileiro, referente à redução à condição análoga a de escravo;

b) a prática definida no artigo $1^{\circ}$ da Convenção Suplementar sobre a Abolição da

Escravatura, do Tráfico de Escravos e das Instituições e Práticas Análogas à Escravatura, como sendo o casamento servil.

$\S 4^{\circ}$ A intermediação, promoção ou facilitação do recrutamento, do transporte, da

transferência, do alojamento ou do acolhimento de pessoas para fins de exploração também configura tráfico de pessoas.

$\S 5^{\circ} \mathrm{O}$ tráfico interno de pessoas é aquele realizado dentro de um mesmo estado-membro da Federação, ou de um estado-membro para outro, dentro do território nacional.

$\S 6^{\circ} \mathrm{O}$ tráfico internacional de pessoas é aquele realizado entre Estados distintos.

$\S 7^{\circ} \mathrm{O}$ consentimento dado pela vítima é irrelevante para a configuração do tráfico de pessoas.

\section{Capítulo II}

\section{Princípios e Diretrizes \\ Seção I \\ Princípios}

Art. $3^{\circ}$ São princípios norteadores da Política Nacional de Enfrentamento ao Tráfico de Pessoas:

I - respeito à dignidade da pessoa humana;

II - não-discriminação por motivo de gênero, orientação sexual, origem étnica ou social, procedência, nacionalidade, atuação profissional, raça, religião, geracional, situação migratória ou outro status; 
III - proteção e assistência integral ás vítimas diretas ou indiretas, independente de nacionalidade e de colaboração em processos judiciais; IV - promoção e garantia da cidadania e dos direitos humanos;

$V$ - respeito a tratados e convenções internacionais de direitos humanos; VI - universalidade, indivisibilidade e interdependência dos direitos humanos;

VII - transversalidade das dimensões de gênero, orientação sexual, origem étnica ou social, procedência, raça e geracional nas políticas públicas.

Parágrafo único. A Política Nacional de Enfrentamento ao Tráfico de Pessoas observará os princípios da proteção integral da criança e do adolescente.

\section{Seção II Diretrizes Gerais}

Art. $4^{\circ}$ São diretrizes gerais da Política Nacional de Enfrentamento ao Tráfico de Pessoas:

I - fortalecimento do pacto federativo, por meio da atuação conjunta e articulada de todas as esferas de governo na prevenção e repressão ao tráfico de pessoas, bem como no atendimento e reinserção social das vítimas;

II - fomento à cooperação internacional bilateral e/ou multilateral;

III - articulação com organizações não-governamentais, nacionais e internacionais;

IV - estruturação de rede de enfrentamento ao tráfico de pessoas, envolvendo todas as esferas de governo e organizações da sociedade civil;

V - fortalecimento da atuação nas regiões de fronteiras, em portos, aeroportos, rodovias, estações rodoviárias e ferroviárias, e demais áreas de incidências;

VII - verificação da condição de vítima e respectiva proteção e atendimento, no exterior e em território nacional, bem como sua reinserção social;

VIII - incentivo e realização de pesquisas, considerando as diversidades regionais, organização e compartilhamento de dados;

IX - incentivo à formação e à capacitação de profissionais para a prevenção e repressão ao tráfico de pessoas, bem como para a verificação da condição de vítima e para o atendimento e reinserção social das vítimas;

X - harmonização das legislações e procedimentos administrativos nas esferas federal, estadual e municipal relativa ao tema;

$\mathrm{XI}$ - incentivo à participação da sociedade civil em instâncias de controle social das políticas públicas na área de enfrentamento ao tráfico de pessoas;

XII - incentivo à participação dos órgãos de classe e conselhos profissionais na discussão sobre tráfico de pessoas; 
XIII - garantia de acesso amplo e adequado a informações em diferentes mídias e

estabelecimento de canais de diálogos, entre o Estado, sociedade e meios de comunicação, referentes ao enfrentamento ao tráfico de pessoas.

\section{Seção III Diretrizes Específicas}

Art. $5^{\circ}$ São diretrizes específicas de prevenção ao tráfico de pessoas:

I - implementação de medidas preventivas nas políticas públicas, de maneira integrada e intersetorial, nas áreas de saúde, educação, trabalho, segurança, justiça, turismo, assistência social, desenvolvimento rural, esportes, comunicação, cultura, direitos humanos, dentre outras;

II - apoio e realização de campanhas socioeducativas e de conscientização nos âmbitos internacional, nacional, regional e local, considerando as diferentes realidades e linguagens;

III - criação de instrumentos de monitoramento e avaliação de campanhas com a

participação da sociedade civil;

IV - apoio à mobilização social e fortalecimento da sociedade civil;

$\mathrm{V}$ - fortalecimento dos projetos já existentes e fomento à criação de novos projetos de prevenção ao tráfico de pessoas.

Art. $6^{\circ}$ São diretrizes específicas de repressão ao tráfico de pessoas e de responsabilização de seus autores:

I - cooperação entre policiais nacionais e internacionais;

II - cooperação jurídica internacional;

III - sigilo dos procedimentos judiciais;

IV - integração com as políticas e ações de repressão e responsabilização dos autores de crimes correlatos.

Art. $7^{\circ}$ São diretrizes específicas de atenção às vítimas do tráfico de pessoas:

I - proteção e assistência jurídica, social e de saúde às vítimas diretas e indiretas de tráfico de pessoas;

II - assistência consular às vítimas diretas e indiretas de tráfico de pessoas,

independentemente de sua situação migratória e ocupação;

III - acolhimento e abrigo provisório das vítimas de tráfico de pessoas;

IV - reinserção social com a garantia de acesso à educação, formação profissional e ao trabalho às vítimas de tráfico de pessoas;

$\mathrm{V}$ - reinserção familiar e comunitárias de crianças e adolescentes vítimas de tráfico de pessoas;

VI - atenção às necessidades específicas das vítimas, com especial atenção a questões de gênero, orientação sexual, origem étnica ou social, procedência, nacionalidade, raça, religião, geracional, situação migratória, atuação profissional ou outro status;

VII - proteção da intimidade e da identidade das vítimas de tráfico de pessoas; 
VIII - levantamento, mapeamento, atualização e divulgação de informações sobre

instituições governamentais e não-governamentais situadas no Brasil e no exterior que prestam assistência a vítimas de tráfico de pessoas.

\section{Capítulo III Ações}

Art. $8^{\circ} \mathrm{Na}$ implementação da Política Nacional de Enfrentamento ao Tráfico de Pessoas, os órgãos e entidades públicos desenvolverão, no âmbito de suas respectivas competências, as seguintes ações:

I - na área de Justiça e Segurança Pública:

a) proporcionar atendimento inicial humanizado às vítimas de tráfico de pessoas que retornam ao país na condição de deportadas ou não admitidas nos aeroportos, portos e pontos de entrada em vias terrestres;

b) elaborar proposta intergovernamental de aperfeiçoamento da legislação brasileira relativa ao enfrentamento do tráfico de pessoas e crimes correlatos;

c) fomentar a cooperação entre os órgãos federais, estaduais e municipais ligados à segurança pública para atuação articulada na prevenção e repressão ao tráfico de pessoas e responsabilização de seus autores;

d) propor e incentivar a adoção do tema de tráfico de pessoas e direitos humanos nos currículos de formação dos profissionais de segurança pública e operadores do Direito, federais, estaduais e municipais, para capacitação, quando do ingresso na instituição e de forma continuada, para o enfrentamento a este tipo de crime;

e) fortalecer as rubricas orçamentárias existentes e criar outras voltadas para a formação dos profissionais de segurança pública e de justiça na área de enfrentamento ao tráfico de pessoas;

f) incluir nas estruturas específicas de inteligência policial a investigação e repressão ao tráfico de pessoas;

g) criar, nas Superintendências Regionais do Departamento de Polícia Federal e da Polícia Rodoviária Federal, estruturas específicas para o enfrentamento do tráfico de pessoas e outros crimes contra os direitos humanos;

h) promover a aproximação dos profissionais de segurança pública e operadores do Direito com a sociedade civil;

i) celebrar acordos de cooperação com organizações da sociedade civil que atuam na prevenção ao tráfico de pessoas e no atendimento às vítimas;

j) promover e incentivar, de forma permanente, cursos de atualização sobre tráfico de pessoas, para membros e servidores dos órgãos de justiça e segurança pública, preferencialmente por meio de suas instituições de formação;

I) articular os diversos ramos do Ministério Público dos Estados e da União, da

Magistratura Estadual e Federal e dos órgãos do sistema de justiça e segurança pública; 
m) organizar e integrar os bancos de dados existentes na área de enfrentamento ao tráfico de pessoas e áreas correlatas;

n) celebrar acordos de cooperação técnica com entidades públicas e privadas para subsidiar a atuação judicial e extrajudicial;

o) incluir o tema de tráfico de pessoas nos cursos de combate à lavagem de dinheiro, ao tráfico de drogas e armas e a outros crimes correlatos;

p) desenvolver, em âmbito nacional, mecanismos de prevenção, investigação e repressão ao tráfico de pessoas cometido com o uso da rede mundial de computadores, e consequente responsabilização de seus autores;

q) incluir a possível relação entre o desaparecimento e o tráfico de pessoas em pesquisas investigações policiais.

II - nas áreas de Relações Exteriores:

a) propor e elaborar instrumentos de cooperação internacional na área do enfrentamento ao tráfico de pessoas;

b) iniciar processos de ratificação dos instrumentos internacionais referentes ao tráfico de pessoas;

c) inserir no Manual de Serviço Consular e Jurídico do Ministério das Relações Exteriores um capítulo específico de assistência consular às vítimas de tráfico de pessoas;

d) incluir o tema de tráfico de pessoas nos cursos de remoção oferecidos aos servidores do Ministério de Relações Exteriores;

e) promover a coordenação das políticas referentes ao enfrentamento ao tráfico de pessoas em fóruns internacionais bilaterais e multilaterais;

f) propor e apoiar projetos de cooperação técnica internacional na área de enfrentamento ao tráfico de pessoas;

g) coordenar e facilitar a participação brasileira em eventos internacionais na área de enfrentamento ao tráfico de pessoas;

h) fortalecer os serviços consulares na defesa e proteção de vítimas de tráfico de pessoas.

III - na área de Educação:

a) celebrar acordos com instituições de ensino e pesquisa para o desenvolvimento de estudos e pesquisas relacionados ao tráfico de pessoas;

b) incluir a questão do tráfico de pessoas nas ações e resoluções do Fundo Nacional de Desenvolvimento da Educação do Ministério da Educação (FNDE/MEC);

c) apoiar a implementação de programas e projetos de prevenção ao tráfico de pessoas nas escolas;

d) incluir e desenvolver o tema do enfrentamento ao tráfico de pessoas nas formações continuadas da comunidade escolar, em especial os trabalhadores da educação;

e) promover programas intersetoriais de educação e prevenção ao tráfico de pessoas para todos os atores envolvidos;

f) fomentar a educação em direitos humanos com destaque ao enfrentamento ao tráfico de pessoas em todas as modalidades de ensino, inclusive no ensino superior. 
IV - na área de Saúde:

a) garantir atenção integral para as vítimas de tráfico de pessoas e potencializar os serviços existentes no âmbito do Sistema único de Saúde;

b) acompanhar e sistematizar as notificações compulsórias relativas ao tráfico de pessoas sobre suspeita ou confirmação de maus-tratos, violência e agravos por causas externas relacionadas ao trabalho;

c) propor a elaboração de protocolos específicos para a padronização do atendimento às vítimas de tráfico de pessoas;

d) capacitar os profissionais de saúde na área de atendimento às vítimas de tráfico de pessoas.

V - na área de Assistência Social:

a) oferecer assistência integral às vítimas de tráfico de pessoas no âmbito do Sistema único de Assistência Social;

b) propiciar o acolhimento de vítimas de tráfico, em articulação com os sistemas de saúde, segurança e justiça;

c) capacitar os operadores da assistência social na área de atendimento às vítimas de tráfico de pessoas;

d) apoiar a implementação de programas e projetos de atendimento específico às vítimas de tráfico de pessoas.

$\mathrm{VI}$ - na área de Promoção da Igualdade Racial:

a) garantir a inserção da perspectiva da promoção da igualdade racial nas políticas governamentais de enfrentamento ao tráfico de pessoas;

b) apoiar as experiências de promoção da igualdade racial empreendidas por municípios, Estados e organizações da sociedade civil voltadas à prevenção ao tráfico de pessoas e atendimento às vítimas;

c) promover a realização de estudos e pesquisas sobre o perfil das vítimas de tráfico de pessoas, com ênfase na população negra e outros segmentos étnicos da população brasileira.

VII - na área do Trabalho e Emprego:

a) orientar os empregadores e entidades sindicais sobre aspectos ligados ao recrutamento e deslocamento de trabalhadores de uma localidade para outra;

b) fiscalizar o recrutamento e o deslocamento de trabalhadores para localidade diversa do município ou Estado de origem;

c) propor ações judiciais na Justiça do Trabalho para garantir os direitos dos trabalhadores;

d) promover articulação com entidades profissionalizantes visando capacitar e reinserir a vítimas no mercado de trabalho;

e) fiscalizar os imóveis que constam nos Cadastros de Empregadores que tenham mantido trabalhadores em condições análogas a de escravo.

VIII - na área de Desenvolvimento Agrário:

a) diminuir a vulnerabilidade do trabalhador e prevenir o recrutamento mediante políticas específicas na área de desenvolvimento rural;

b) promover a desapropriação para fins de reforma agrária, por descumprimento da função social trabalhista, de imóveis rurais nas 
regiões de resgate dos trabalhadores submetidos a trabalho forçado ou a condições análogas a de escravo;

c) promover ações articuladas com parceiros que atuam nos Estados de origem dos trabalhadores recrutados;

d) formar parcerias no que tange à assistência técnica para avançar na implementação da Política Nacional de Assistência Técnica e Extensão Rural;

f) excluir da participação em certames licitatórios e restringir o acesso aos recursos do crédito rural a todas as pessoas físicas ou jurídicas que explorem o trabalho forçado e/ou em condição análoga a de escravo;

g) promover a reinclusão de trabalhadores libertados e de resgate de cidadania, mediante criação de uma linha específica, em parceria com o Ministério da Educação, para alfabetização e formação dos trabalhadores resgatados, de modo que possam atuar como agentes multiplicadores para a erradicação do trabalho forçado e do trabalho em condição análoga a de escravo;

h) incentivar os Estados, municípios e demais parceiros a acolher e prestar apoio específico aos trabalhadores libertados, por meio de capacitação técnica.

IX - na área dos Direitos Humanos:

a) proteger vítimas, réus colaboradores e testemunhas de crimes de tráfico de pessoas;

b) receber denúncias de tráfico de pessoas através do serviço de disquedenúncia nacional, dando o respectivo encaminhamento;

c) incluir ações específicas sobre enfrentamento ao tráfico de pessoas e fortalecer ações existentes no âmbito de programas de prevenção à violência e garantia de direitos;

d) proporcionar proteção aos profissionais que atuam no enfrentamento ao tráfico de pessoas e que, em função de suas atividades, estejam ameaçados ou se encontrem em situação de risco;

e) incluir o tema do tráfico de pessoas nas capacitações dos Conselhos de Direitos da criança e do Adolescente e Conselhos Tutelares;

f) articular ações conjuntas de enfrentamento ao tráfico de crianças e adolescentes em regiões de fronteira;

g) promover, em parceria com os órgãos e entidades diretamente responsáveis, a prevenção ao trabalho escravo, através da sensibilização de operadores de Direito, orientação a produtores rurais acerca dos direitos trabalhistas, educação e capacitação de trabalhadores rurais;

h) disponibilizar mecanismos de aceso a direitos, incluindo documentos básicos,

preferencialmente nos municípios identificados como focos de aliciamento de mão-de-obra para trabalho escravo.

X - na área de Proteção e Promoção dos Direitos da Mulher:

a) qualificar os profissionais da área de atendimento à mulher em situação de violência para o atendimento à mulher traficada;

b) incentivar a prestação de serviços de atendimento às mulheres traficadas nos Centros de Referência de Atendimento à Mulher em Situação de Violência; 
c) apoiar e incentivar programas e projetos de qualificação profissional, geração de emprego e renda que tenham como beneficiárias diretas mulheres traficadas;

d) fomentar debates sobre questões estruturantes favorecedoras do tráfico de pessoas e relativas à discriminação de gênero nas políticas públicas básicas, assistenciais e especiais;

e) promover ações de articulação intersetoriais visando a inserção da dimensão de gênero nas políticas públicas básicas, assistenciais e especiais;

f) apoiar programas, projetos ações de educação não-sexista e de promoção da diversidade no ambiente profissional e educacional;

g) participar das capacitações visando garantir a temática de gênero;

h) promover em parceria com organizações governamentais e nãogovernamentais debates sobre metodologias de atendimento às mulheres traficadas.

$\mathrm{XI}$ - na área do Turismo:

a) incluir o tema do tráfico de pessoas, em especial mulheres, crianças e adolescentes nas capacitações e eventos de formação dirigidos à cadeia produtiva do turismo;

b) cruzar os dados dos diagnósticos feitos nos municípios para orientar os planos de desenvolvimento turístico local através do programa de regionalização;

c) promover campanhas de sensibilização contra o turismo sexual como forma de

prevenção ao tráfico de pessoas.

XII - na área de Cultura:

a) desenvolver políticas culturais com o foco na prevenção ao tráfico de pessoas;

b) fomentar e estimular atividades culturais, tais como programas regionais de rádio, peças e outros programas veiculados por radiodifusores, que possam aumentar a conscientização da população com relação ao tráfico de pessoas, trabalho escravo e exploração sexual, respeitadas as características regionais. 